Universidade Federal de Juiz de Fora

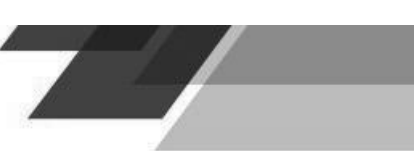

UNIVERSIDADE FEDERAL DE JUIZ DE FORA

FACULDADE DE EDUCAÇÃO

PROGRAMA DE PÓS-GRADUAÇÃO EM EDUCAÇÃO

Maria Rita Neves Ramos

Maternagem e Cuidado como desejo de Democracia:

Educação Infantil em perspectiva Feminista

JUIZ DE FORA 
Maria Rita Neves Ramos

\section{MATERNAGEM E CUIDADO COMO DESEJO DE DEMOCRACIA: EDUCAÇÃO INFANTIL EM PERSPECTIVA FEMINISTA}

Tese apresentada ao Programa de Pós-graduação em Educação da Universidade Federal de Juiz de Fora, como requisito parcial à obtenção do título de Doutora em Educação. Área de concentração: "Educação brasileira: gestão e práticas pedagógicas".

Orientadora: Prof. . . Dr. ${ }^{a}$ Daniela Auad 
Ficha catalografica elaborada atraves do programa de geraçao automatica da Biblioteca Universitaria da UFJF. com os dados fornecidos pelo(a) autor(a)

\section{Ramos, Maria Rita Neves}

Maternagem e Cuidado como desejo de Democracia : Educação Infantil em perspectiva Feminista / Maria Rita Neves Ramos, -- 2021. $272 \mathrm{p}$.

Orientador: Daniela Auad

Tese (doutorado) - Universidade Federal de Juiz de Fora,

Faculdade de Educaçào. Programa de Pos-Graduaçâo em

Educaçăo, 2021.

1. Tese. I. Auad, Daniela, orient. II. Titulo. 


\section{Maria Rita Neves Ramos}

Maternagem e cuidado como desejo de democracia: educação infantil em perspectiva feminista

Tese apresentada ao Programa de Pós-graduação em Educação da Universidade Federal de Juiz de Fora, como requisito parcial à obtenção do título de Doutora em Educação. Área de concentração: "Educação brasileira: gestão e práticas pedagógicas".

Aprovada em 27 de maio de 2021.

\section{BANCA EXAMINADORA}

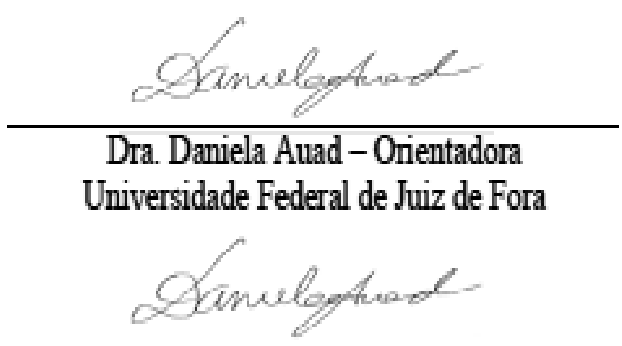

P/ Dra. Elita Betania de Andrade Martins

Universidade Federal de Juiz de Fora

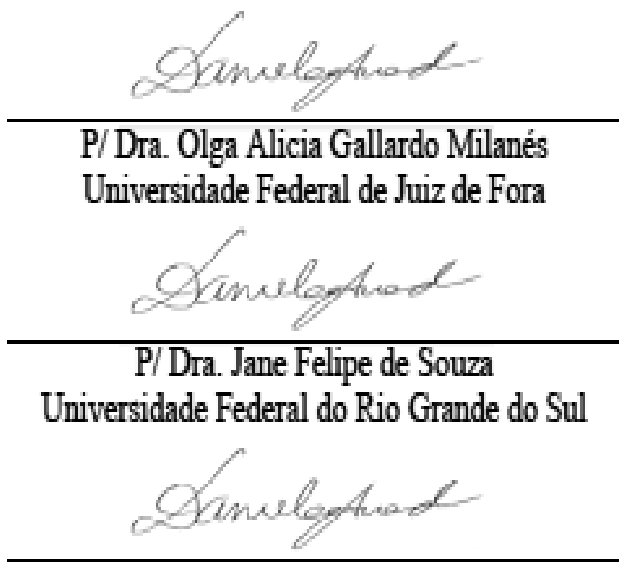

P/Dra. Ana Liési Thurler

Universidade de Brasilia 
Para Christina, minha árvore, e Diego e Dudu, minhas sementes. 


\section{AGRADECIMENTOS}

A ideia do agradecimento, para mim, está ligada à retribuição da generosidade e do amor. De muitas formas, em meus muitos percursos, fui presenteada com relações que transbordaram, e transbordam tais princípios, fundamentais à minha formação.

Muita gratidão às professoras Ana Liési Thurler, Jane Felipe de Souza, Olga Alicia Gallardo Millanes e Elita Betania de Andrade Martins, por aceitarem e compartilharem da avaliação da tese em minha banca de defesa. Muito obrigada às professoras Nubia Aparecida Schaper Santos e Ana Luisa Alves Cordeiro, e aos professores Jader Janer Moreira Lopes e Luciano Nascimento Corsino, por aceitarem o convite para compor a suplência. Agradeço imensamente as contribuições das professoras Ana Luiza Alves Cordeiro e Rita de Cássia Pimenta de Araújo Pimenta, na ocasião do exame de qualificação.

Estendo meu agradecimento às professoras e professores da Faculdade de Educação e da Pós Graduação em Educação da UFJF, por marcarem, de múltiplos modos, minha vida acadêmica;

Gratidão eterna ao Flores Raras, grupo de pesquisa que por me proporcionou tantas descobertas, alegrias, emoções, questionamentos e parcerias;

Muito obrigada, Daniela Auad, minha orientadora que, nesses 10 anos de parceria, da graduação à pós, me maternou, para muito além da escrita do TCC, da dissertação e da tese;

Meu muito obrigada às educadoras da creche-campo, pela troca de experiências, sentimentos, no mais intenso diálogo e reflexões conjuntas pela Educação. Mais que professoras, mulheres falantes, que ao externarem suas vozes, proporcionaram momentos e aprendizados extremamente marcantes!

Obrigada, Vanusa, por revisar meu texto e me presentear com nossas deliciosas conversas de final de tarde. Agradeço enormemente ter podido contar com o suporte de Frederico, sempre iluminando o melhor de mim, representando a calmaria em meio ao turbilhão de emoções durante o processo de Doutoramento.

Meu agradecimento também às colegas da pós-graduação, da turma do Doutorado de 2017. Elis, Fabiana, Lu, Thiago, Silvia, Airam, Carla, Luciane, Helena, Fernanda, Josi, Luciene, Cris e Janaína, muito obrigada pela companhia, vibração positiva e trocas de pesquisa, e por maternarmos juntas, o Doutorado, o Diego, a Laura, o Francisco, o Gil e o Thomas, nossos bebês! 
Dos encontros mais lindos desse mundo, da pós para a vida, meu muito obrigada a Luciene Mochi, Carla Romão e Luisa Bitencourt, pelos afetos e feminismos exercidos corajosamente, e cotidianamente.

Agradeço também a dádiva de ter nascido em uma família de mulheres fortes e determinadas. Minha mãe, Christina, mulher doce e inspiradora, segue me acolhendo, do plano espiritual, assim como minha avó, Therezinha. Obrigada por me darem tanto amor, e tantas lições de vida! Carmen, Silvana, Bárbara, Vanda, lindas primas-companheiras que compartilham afetos. Maria Helena, minha Mama, obrigada pelo coração que me abraça! Mulheres valorosas, toda a minha admiração!

E o que dizer das amigas? Dos amigos? Ah, as minhas amadas e amados! Dani, Juliana, Hellen Sara, Jéssica, Helen, minhas pedagogas preferidas, não existem palavras para agradecer a cumplicidade! Obrigada também ao Ivan, das paisagens da vida à construção da paisagem da tese. Gratidão, Jean! Elisângela e Raquel, amigas e parceiras dos cotidianos mais simples, mas não menos afetuosos e singelos. Dani Munck, obrigada pela presença, e pelo exercício cotidiano de fraternidade e amor.

Em especial, meu muito obrigada a você, Léo, meu adorável companheiro, pelo apoio e incentivo incondicionais. Nos momentos mais difíceis, você me fez seguir adiante, e cá estamos, completando a jornada (e que jornada!!). Dudu, filho querido, e Diego, meu pequeno que nasceu junto com o Doutorado. Vocês são meu coração fora do peito, amo muito vocês! 
Eu tenho pressa, eu quero ir pra rua, quero ganhar a luta que eu travei

Eu quero andar pelo mundo a fora, vestida de brilho e flor

Mulher, a culpa que tu carrega não é tua

Divide o fardo comigo dessa vez

Que eu quero fazer poesia pelo corpo, e afrontar as leis

Que o homem criou pra dizer.

(Ekena Monteiro) 


\section{RESUMO}

Este trabalho tem como objetivo conhecer as relações de maternagem na Educação Infantil a partir do diálogo e reflexão acerca de como tais relações concorrem para assegurar o efetivo exercício dos direitos das mulheres e direito das crianças. Para cumprir o objetivo da pesquisa, estabelecemos como objeto de análise as concepções e práticas escolares relativas à educação das crianças, sobretudo na perspectiva do cuidado. Nesse sentido, cuidado é conceito assumido na pesquisa associado ao debate sobre maternagem, a partir da concepção da manutenção do criar e educar desenvolvida por Dagmar Meyer (2005). A partir das análises e reflexões propostas, a presente pesquisa adota o pressuposto da corresponsabilidade da Educação, já prevista na legislação brasileira, como no Estatuto da Criança e do Adolescente (BRASIL, 1990) e na própria Constituição Federal (BRASIL, 1988). Sendo assim, o foco do estudo se volta ao aparato institucional, social e familiar necessário à educação das crianças, posto que a abordagem adotada percebe a creche como tendo impacto direto nas variadas searas das vidas das mulheres e crianças, sendo esses dois grupos populacionais ainda passíveis de serem minorias sociais, ainda que não sejam minorias numéricas. Diante dessa conjuntura e da necessidade de repensarmos as condições de reconhecimento social de mulheres e crianças, a pesquisa adota como campo a rede de ensino municipal de Juiz de Fora (MG) e busca atingir o objetivo da pesquisa a partir do diálogo sobre como os feminismos exercem (ou não) influência nas práticas educadoras da Educação Infantil, de modo a assegurar que este nível de ensino seja seara de direitos das populações que recorrem à creche como equipamento de Estado. Foram realizados encontros formativos com as professoras da creche e as discussões foram fundamentadas em textos e materiais audiovisuais, na perspectiva de diálogo sobre a Educação Infantil e a garantia e manutenção de direitos das mulheres e direitos das crianças. As reflexões produzidas nos encontros formativos indicam que a Educação Infantil é um contexto potente, porém desafiador, ao debate da maternagem.

\section{Palavras-chave: Educação Infantil; Creche; Cuidado; Maternagem; Feminismos;}

\section{Democracia.}




\begin{abstract}
This research has a purpose to know the motherhood's relationship in the Childhood Education from now of the discussion and reflection about of the how such relationships cooperate for ensure the effective exercise of the women's rights and children's rights. To comply the objectives of the research, established as analysis object the conceptions and school practices related for the children's education, especially in the perspective of the care. That way, care is concept assumed in the research associated with the debate about motherhood, from the conception of the maintenance to create and educate developed by Dagmar Meyer (2005). From of the analyses and reflections proposed, the current research adopt the assumption of the co-responsibility of the Education, already planned in the Brazilian's legislation, as in the Statute of the Child and Adolescent (BRASIL, 1990) and in the own Federal Constitution (BRASIL, 1988). Therefore, the focus of the research returns to the apparatus institutional, social and familiar necessary for children's education, because the adopt approach understand the crèche how having direct impact in the varied sectors of the women's lives and children's lives, being these two population groups still susceptible of being social minorities, even though are not numerical minorities. Before this situation and of the necessity of the rethink the conditions for social recognition of the women and children, the research adopts how field the municipal education network of the Juiz de Fora (MG) and seeks to reach the research's objective from of the dialogue about how the feminisms exercise (or not) influences in the educator's practices of the Childhood Education, in a manner that insures that this level of education be right's sector of the populations that resort to crèche how Equipment State. Have been made educational encounters with the crèche's teachers and the debates were in texts and audiovisual materials, from the perspective of the dialogue about the Childhood Education and the guarantee of the maintenance of women's rights and children's rights. The reflections produced in the educational encounters indicate that the Childhood Education is a powerful context, however challenging, to the debate about motherhood.
\end{abstract}

Keywords: Childhood Education; Crèche; Care; Motherhood; Feminisms, Democracy 


\section{LISTA DE ILUSTRAÇÕES E QUADROS}

Quadro 1: Detalhamento de exclusão de trabalhos - pesquisa bibliográfica .................................................. 34

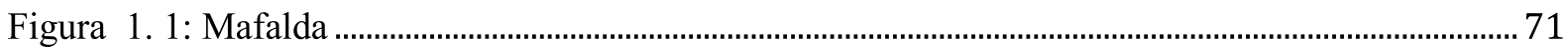

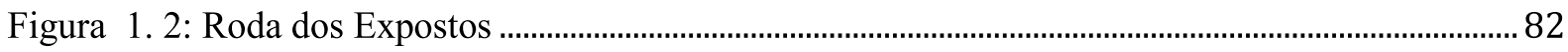

Figura 2. 1: Movimento por Creches - São Paulo (1979) ……………………………...............................90

Figura 3. 1: Família pobre recolhendo o produto do trabalho da negra velha que carrega água".........136

Quadro 3. 1: Comparativo de creches e pré-escolas por região..................................................................151

Figura 3. 2: Delimitação do município de Juiz de Fora (MG) …………………………………………....153

Figura 4. 1: Sala de aula e ilustração do corredor da creche.......................................................................176

Figura 4. 2: Parquinho e banheiro das crianças ........................................................................................176

Figura 4. 3: Participante Juliana................................................................................................................178

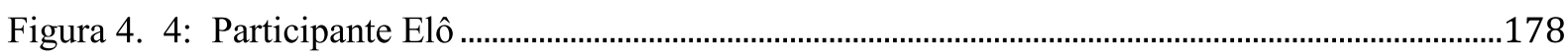

Figura 4. 5: Comentário Sueli..................................................................................................................179

Figura 4. 6: Comentário Sueli...................................................................................................................181

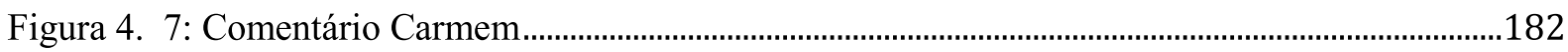

Figura 4. 8: Comentário Christina.........................................................................................................183

Figura 4. 9: Comentário Elisângela ....................................................................................................184

Figura 5. 1: Campanha de planejamento familiar Prefeitura de Quaraí......................................................222

Figura 5. 2: Representações na Entrada e no Refeitório da creche ...........................................................227

Figura I. 1: É necessária a aldeia inteira para educar uma criança. ............................................................24 


\section{LISTA DE SIGLAS}

AIC

AMAC

BNCC

CLT

$\mathrm{CNE}$

CNDM

COEDI

COEPRE

CNCC

CPI

CNBB

CRAS

DCNEI

DEI

$\mathrm{DNCr}$

ECA

EMEI

FACED

FENAJ

FNDC

FUNABEM
Ano Internacional da Criança

Associação Municipal de Apoio Comunitário

Base Curricular Nacional Comum

Consolidação das Leis do Trabalho

Conselho Nacional de Educação

Conselho Nacional dos Direitos da Mulher

Coordenação Geral de Educação Infantil

Coordenação de Educação Pré-escolar

Comissão Nacional Criança e Constituinte

Comissão Parlamentar de Inquérito

Pastoral da Criança e Conferência Nacional dos Bispos do Brasil

Centro de Referência de Assistência Social

Diretrizes Curriculares Nacionais para a Educação Infantil

Departamento de Educação Infantil

Departamento Nacional da Criança

Estatuto da Criança e do Adolescente

Escolas Municipais de Educação Infantil

Faculdade de Educação

Federação Nacional dos Jornalistas

Frente Nacional dos Direitos da Criança

Fundação do Bem Estar do Menor 
IBGE

IDF

INEP

IPEA

LDBEN

LOAS

MDS

MEC

MIESP

MOBRAL

MPMG

MPT

NDI

$\mathrm{OAB}$

OCDE

PAPPE

PDE

PME

PNE

PNAD

UNESCO

UNICEF
Instituto Brasileiro de Geografia e Estatística

Índice de Desenvolvimento Familiar

Instituto Nacional de Estudos e Pesquisas Educacionais Anísio Teixeira)

Instituto de Pesquisa Econômica Aplicada

Lei de Diretrizes e Bases da Educação Nacional

Lei Orgânica da Assistência Social

Ministério do Desenvolvimento Social

Ministério da Educação e Cultura

Ministério da Educação e Saúde Pública

Movimento Brasileiro de Alfabetização

Ministério Público de Minas Gerais

Ministério Público do Trabalho

Núcleo de Desenvolvimento da Infância

Ordem dos Advogados do Brasil

Organização de Cooperação e de Desenvolvimento Econômico

Programa de Atendimento e Promoção ao Pré-Escolar

Plano de Desenvolvimento da Educação

Plano Municipal de Educação

Plano Nacional de Educação

Pesquisa Nacional por Amostra de Domicílios

Organização das Nações Unidas para a Educação, Ciência e Cultura

Fundo das Nações Unidas para a Infância 


\section{SUMÁRIO}

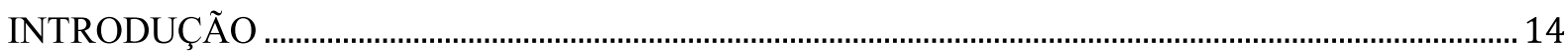

A- BASES TEÓRICAS: O QUE DIVULGAM AS FONTES BIBLIOGRÁFICAS............................. 27

B- APROXIMAÇÃO DO CAMPO: METODOLOGIA DA PESQUISA ……………………………...... 35

1. CONCEITOS E SUAS TRAJETÓRIAS: MATERNAGEM, CUIDADO E EDUCAÇÃO................ 42

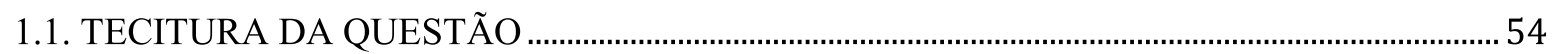

1.2. O CUIDAR E O EDUCAR NA EDUCAÇÃO INFANTIL - O FAZER PEDAGÓGICO

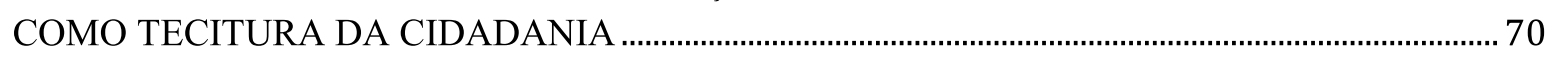

1.3. PRÁTICAS DE MATERNAGEM: PENSAR A EDUCAÇÃO PARA ALÉM DOS DITAMES CONSERVADORES

2 - MARCOS HISTÓRICOS DOS FEMINISMOS NA LUTA POR CRECHES: DADOS DO

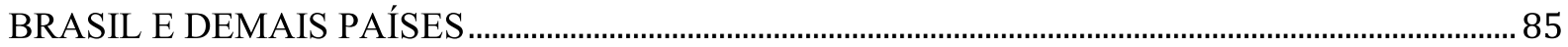

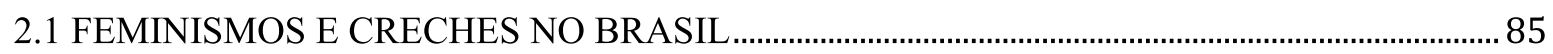

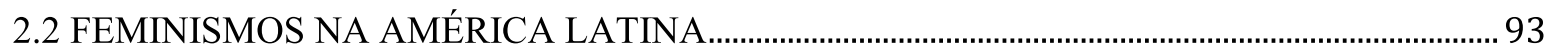

2.3 UM GIRO PELA EUROPA: EDUCAÇÃO E ATENÇÃO ÀS CRIANÇAS PEQUENAS .......117

3. CONHECENDO O TERRENO: A POLÍTICA E O POLÍTICO DA EDUCAÇÃO INFANTIL ...132

3.1 A DEMOCRATIZAÇÃO DA EDUCAÇÃO INFANTIL NO BRASIL ...........................................133

3.2 EDUCANDO CRIANÇAS PEQUENAS EM JUIZ DE FORA (MG) ..............................................152

3.3 AMAC: UM CAPÍTULO IMPORTANTE NA EDUCAÇÃO INFANTIL DE JUIZ DE FORA

(MG)

3.4. QUADRO ATUAL DA EDUCAÇÃO INFANTIL JUIZ-FORANA: INSTITUIÇÕES, ACESSO E FORMULAÇÕES EDUCACIONAIS ............................................................................166

4. RETRATOS DO CAMPO: A DIMENSÃO DOS DIREITOS DAS CRIANÇAS E DAS MULHERES A PARTIR DA CRECHE.........................................................................................173

4.1 ENCONTRO PRELIMINAR: APRESENTANDO A CRECHE E AS PARTICIPANTES DOS

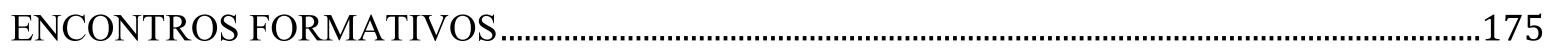

4.2 "UM LAÇO DE GRANDES DESCOBERTAS, APRENDIZAGEM E AMOR”: MÃES,

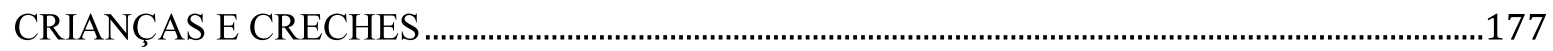

4.3 “A PÚBLICA É MAIS O CUIDADO, O PARTICULAR É MAIS O PEDAGÓGICO”: VISÕES

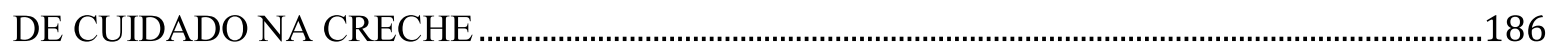
4.4 "A GENTE TEM QUE PRESERVAR OS SONHOS E APRESENTAR ESSA REALIDADE":

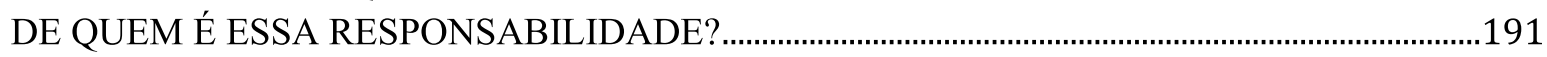
4.5 "SÓ NÃO ACHO QUE PRECISA FICAR FALANDO”: CONTRADIÇÕES PARA PENSAR

5. OUTROS TERRITÓRIOS E CONJUNTURAS DE UM MESMO CAMPO . .212

5.1 “ARRUMA UM IRMÃOZINHO PARA ELE”: O QUE NÃO APARECE, MAS SE FAZ PRESENTE NO CURRÍCULO. 
5.2 “MUITO DIFÍCIL SER MULHER”: REFLEXÕES SOBRE GÊNERO, VIOLÊNCIA E CONCEPÇÃO

5.3 "EU NUNCA TINHA PARADO PARA PENSAR NISSO": NUANCES DO ANTIFEMINISMO E DO ANTINTELECTUALISMO

5.4 AS DISPUTAS DE PODER NA CRECHE: UM TERRITÓRIO DEMOCRÁTICO EM

POTENCIAL

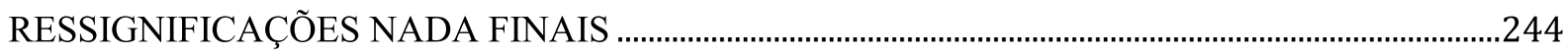

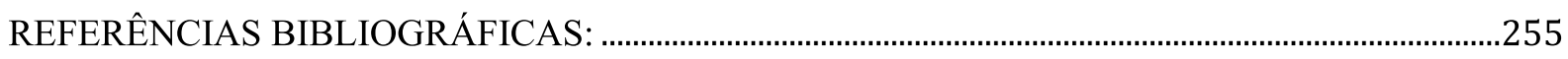

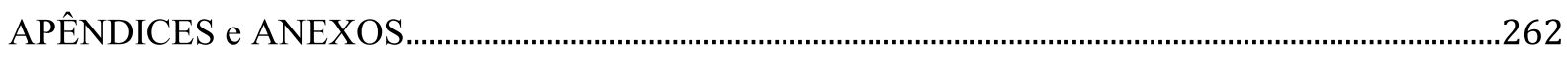

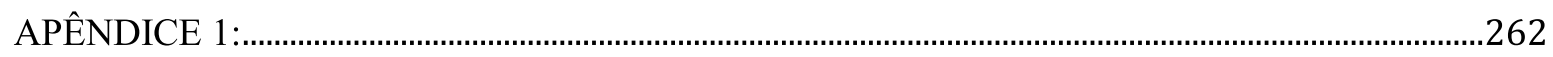

TERMO DE CONSENTIMENTO LIVRE E ESCLARECIDO........................................................262

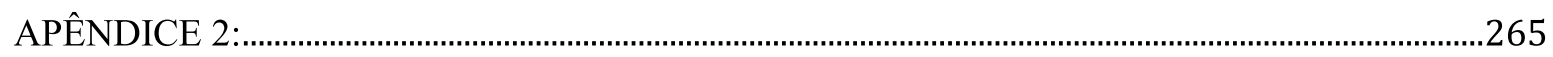

TRABALHOS SELECIONADOS - PESQUISA BIBLIOGRÁFICA ……...........................................265

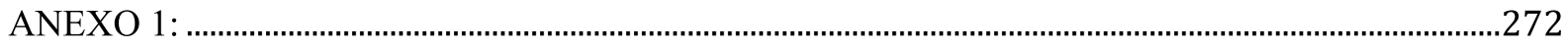

CARTAZ DE CHAMADA PÚBLICA PARA CADASTRAMENTO EM CRECHES EM JUIZ DE FORA (MG) 


\title{
INTRODUÇÃO
}

\begin{abstract}
A procriação não teria sentido se a mãe não completasse sua obra assegurando, até o fim, a sobrevivência do feto e a transformação do embrião num indivíduo acabado. Essa convicção é corroborada pelo uso ambíguo do conceito de maternidade que remete ao mesmo tempo a um estado fisiológico momentâneo, a gravidez, e a uma ação a longo prazo: a maternagem e a educação. A função materna, levada ao seu limite extremo, só terminaria quando a mãe tivesse, finalmente, dado à luz um adulto.
\end{abstract}

(BADINTER, 1985, p.19).

Extraído dos escritos da filósofa feminista francesa Elisabeth Badinter, o fragmento acima aponta, a partir da provocação da autora, a temática central deste trabalho, que pensa sobre e analisa como as relações de maternagem na Educação Infantil concorrem como garantia democrática do efetivo exercício dos direitos de mulheres e crianças. A presente pesquisa parte do pressuposto de que o acesso aos serviços da Educação Infantil atende tanto às demandas das mulheres - em relação ao trabalho e outras atividades às quais essas se dedicam - quanto ao direito das crianças, no que diz respeito ao acesso e usufruto da Educação. De acordo com estatísticas pelo Censo do Instituto Brasileiro de Geografia e Estatística - IBGE do ano de 2010, o número de mulheres que são as principais responsáveis por seus lares e, por conseguinte, as provedoras de suas famílias, corresponde ao percentual de $87,4 \%{ }^{1}$. Esse dado implica que a educação das crianças fique a cargo de outras pessoas além das próprias mulheres. Logo, essa potente e instigante interface entre os Direitos das Mulheres e os Direitos das Crianças via creche será explorada a bem das relações democráticas. A pretensão original da pesquisa foi realizar estudo comparativo de duas redes de ensino de Educação Infantil da região Sudeste brasileira, respectivamente no município de

\footnotetext{
1 Fonte: https://www.ibge.gov.br/apps/snig/v1/?loc=0\&cat=-15,55,-17,-18,128\&ind=4704acesso em 21/10/2019.
} 
Juiz de Fora (MG) e Duque de Caxias (RJ), considerando as contribuições dos movimentos feministas nessas duas localidades. Contudo, ao longo do percurso do Doutoramento, optamos por nos dedicar somente ao contexto do citado município mineiro².

Entendendo que a maternagem, se concebida como algo social, corresponde ao que está prescrito na Constituição ${ }^{3}$ como obrigação de todas as pessoas em educarem as crianças, posto que o maternar é o cuidar e o educar que zela por todo o desenvolvimento da criança, pensamos que, assim, haveria justiça também para com os direitos das mulheres, uma vez que se estaria combatendo a sobrecarga, a discriminação e a inferiorização social que atinge a todas as mulheres. Partindo dessa premissa, o objetivo dessa pesquisa é perceber como essa maternagem ocorre na creche, por ser esse um ente público que consolida o direito das crianças à educação.

Este trabalho supõe que as assertivas feministas - principalmente na seara da Educação produzem ações que priorizam e favorecem o senso de justiça e igualdade, tanto de oportunidades educacionais às crianças, concebidas a partir de Educação não sexista e não racista, quanto de repercutir positivamente na questão do compartilhamento de responsabilidades das mulheres para com a educação das crianças, especialmente quando se focaliza a Educação Infantil. Desse modo, compartilhamos nesta tese do argumento da socióloga e feminista brasileira Ana Liési Thurler (2009), cujo texto Primeira infância no Brasil do século XXI: desafios ao reconhecimento institucional nos ensina que oferecer uma rede de creches a nossas crianças pode significar transformações nas relações sociais entre mulheres e homens, além de consolidar o respeito aos direitos da criança-cidadã, ou seja, o direito a uma Educação, necessária e urgentemente não sexista.

Em uma breve análise que entrelaça $\mathrm{meu}^{4}$ percurso pessoal e acadêmico, que guiaram meus interesses de pesquisa desenvolvidas na graduação, Mestrado e agora no Doutorado, observo que tanto iniciativas que desconstroem, quanto aquelas que reafirmam as relações de

\footnotetext{
${ }^{2} \mathrm{~A}$ consideração de apenas uma rede de ensino como campo de pesquisa foi ajuste necessário ao bom desenvolvimento do campo, tendo em vista a problemática situação atual referente aos cortes de financiamento de pesquisas.

3 O Capítulo III da Constituição Brasileira, intitulado Da Educação, da Cultura e do Desporto, expressa, em seu $205^{\circ}$ artigo, que : "A educação, direito de todos e dever do Estado e da família, será promovida e incentivada com a colaboração da sociedade, visando ao pleno desenvolvimento da pessoa, seu preparo para o exercício da cidadania e sua qualificação para o trabalho".

${ }^{4}$ A utilização da primeira pessoa do singular se dará somente nesse momento do texto, no qual são expressas vivências pessoais e particulares. Ao longo da tese, nos demais momentos, será utilizada a primeira pessoa do plural tanto em virtude da pesquisa ser de responsabilidade da pesquisadora em formação e de sua orientadora, quanto ao fato de se referir, muitas vezes, a mulheres e professoras, identidades partilhadas por nós.
} 
gênero fazem a diferença nas vivências sociais e educacionais. Dessa maneira, socializo os primeiros "gatilhos" 5 que fizeram aflorar o particular interesse em discussões sobre as expectativas sociais distintivas de um sexo e outro, principalmente quando essas afetam as crianças. Filha de mãe solo - e mais tarde, também eu mesma mãe solo - ouvi muitos julgamentos injustos e descabidos sobre a pessoa de minha mãe, que era mal vista na família por ter tido uma filha sem ter sido casada. Humilhações e lições de moral faziam parte do cotidiano dela, desde a gravidez até o fim de sua vida. Ao presenciar muitos desses momentos, eu não conseguia ver sentido naquelas palavras proferidas pelas pessoas, que inferiorizavam minha mãe como mulher e ser humano puramente por eu ser fruto de uma relação que não certo e que, simplesmente, não resultou em casamento. Essa situação me gerava um profundo desconforto e tristeza. Mesmo demonstrando essa insatisfação perante as colocações das pessoas adultas sobre a minha mãe, meus sentimentos também eram argumento para que, ainda criança, eu mesma fosse também hostilizada, por ser, aos olhos de familiares, uma pessoa incapaz de acessar o discernimento, ao passo de que eu defendia uma conduta "errada".

De maneira mais focalizada à minha pessoa, a educação familiar me devolvia ensinamentos que ora variavam de posturas castradoras, em determinadas situações, passando pela afirmação de supostos "lugares" de mulheres e homens, até algumas manifestações de rompimento com esses modelos de comportamento. No seio familiar, essa permanente tensão de visões de mundo gerava muitas controvérsias $\mathrm{O}$ compartilhamento de brinquedos e tarefas domésticas não se colocava como problema em casa. Já com relação às vivências escolares, a expectativa familiar era a de que as brincadeiras e amizades fossem separadas por sexo. A existência de uma divisão de brincadeiras e amizades também foi apontada pelas participantes da pesquisa de campo, que ao comentarem que as crianças apontam que "- Ah isso é de menino", situaram que tal divisão “- Começa com a questão da cor”, referindo-se às construções sociais sobre o rosa e o azul.

Ao mesmo tempo em que minha família não censurava o meu interesse em brincadeiras de movimento, a mesma era bastante reticente em conceber a minha pouca receptividade em ser presenteada com bonecas ou animais de pelúcia. Também, não era levado em consideração se eu me sentia confortável em cuidar dos primos menores, incumbência que não era delegada a nenhum menino. Esses fatos me remetem à leitura do

\footnotetext{
5 "Gatilho" é uma gíria, ou seja, uma expressão informal, que é utilizada quando se deseja fazer referência a algo que desencadeia uma reação. Fonte: https://www.dicionarioinformal.com.br Acesso em $22 / 03 / 2021$.
} 
livro Educar meninas e meninos: relações de gênero na escola, da professora e feminista brasileira Daniela Auad (2006), acessado na graduação. Nessa obra, a professora ressalta o poder das construções sociais sobre o gênero, que "[...] correspondem ao conjunto de representações construídos em cada sociedade, ao longo de sua história, pra atribuir significados [...]" (AUAD, 2006, p.19). Logo, o que observamos como o conjunto de ideias sobre os sexos é o que denomina o gênero "[...] um produto social que constrói o sexo" (AUAD, 2006, p.20). A autora, também, pondera que o fator tempo exerce influência sobre essas construções, ao observarmos as dinâmicas propostas e discutidas pelos movimentos de mulheres sobre suas muitas maneiras de estar no mundo, ocorridas ao longo das transformações sociais e econômicas nas sociedades. Talvez esse diagnóstico justifique os distintos posicionamentos assumidos por minha família, ora rompendo, ora conservando os modelos de comportamento baseados nas relações de gênero.

Já na escola, o fato de não ter pai era bem constrangedor. Em datas comemorativas, as outras crianças me questionavam a esse respeito, além de eu ser obrigada a confeccionar presentes para alguma outra figura masculina da família que, embora existindo, não assumiam o lugar de pai. O gosto pelo estudo rendia muitos elogios, todos direcionados a manter essa conduta. Boas notas eram felicitadas, e outras, não tão boas, eram recebidas com um olhar de decepção, ocasião em que as professoras sentiam necessidade de pontuar sobre a importância da dedicação, limpeza, cuidado e organização dos cadernos, da letra bem feita e do domínio do conteúdo das matérias. No que diz respeito às interações e brincadeiras, já não fazia tão boa figura. Como sempre gostei de brincadeiras de correr, muitas dessas brincadeiras me renderam cicatrizes nas pernas, braços e rosto, o que ia de encontro às expectativas de comportamento de uma menina. A delicadeza, limpeza, bons modos e boa aparência são aspectos recorrentemente evocados para nos colocar nesse "lugar feminino", o que nos remete às análises da professora brasileira Jane Felipe (2000, p.118), que observa no texto Infância, gênero e sexualidade que "[...] o governo sobre o sexo feminino era exercido de forma rigorosa, exigindo um comportamento de maior recato e pudor em comparação ao homem". Em contrapartida, outros comportamentos que "fogem" a esse suposto lugar também são recorrentes.

$\mathrm{Na}$ creche pesquisada, dentre outros exemplos do que pode ser percebido como transgressão, destacamos o relato de uma brincadeira de uma criança, um menino, que brincava de cozinhar para o seu cachorro, e que ao ser surpreendido com uma repreensão por parte de sua avó, diante da brincadeira "inadequada", pediu que a avó esperasse para que a 
comida não esfriasse, em franca atualização das expectativas conservadoras de gênero, já que a própria professora da criança argumentou para a avó que os homens também são chefes de cozinha. Auad (2004), também, estudou as situações e maneiras que as crianças, assim como eu, transgridem as práticas sexistas na escola, principalmente nas brincadeiras. Em sua tese de Doutorado, intitulada Relações de gênero na escola: da escola mista ao ideal de co-educação, Auad (2004) observou as práticas e brincadeiras do cotidiano de uma escola, e concluiu que as expectativas de gênero podem ser reconstruídas pela agência das crianças na realidade pesquisada, o que a levou a construir suas argumentações sobre uma possibilidade coeducativa de Educação não sexista. Essas foram algumas situações em que rememoro o contato com a diferenciação desigual atribuídas a meninas e meninos, estendendo-se por toda a infância, nas grandes instâncias sociais de convívio que são a família e a escola.

Já o grande marco de vida ligado ao "aprendizado" sobre a diferenciação entre os sexos ocorreu quando fiquei grávida de meu primeiro filho, aos 15 anos. Houve um grande conflito referente à responsabilidade nesse evento: algumas pessoas e amigas atribuíam a mim a falta de cuidado e precaução nas relações sexuais. Outras atribuíam à minha mãe não ter "tomado conta" de mim. De toda forma, a obrigação de gerir, pensar e ponderar sobre tudo o que envolve o ato sexual era (e ainda é) atribuída à figura da mulher, o que me gerou muitos embates desagradáveis. No âmbito da família, a notícia da gravidez foi recebida com muita surpresa, mas diferentemente da atitude tomada à época da gravidez de minha mãe, eu fui apoiada. Tias e primas não compactuavam com a culpabilização da minha pessoa. Isso foi um alento muito grande, tendo em vista que o meu círculo de convivência me recriminou muito, como já relatado. Em decorrência de gravidez na adolescência, abandonei os estudos, retornando ao ensino regular um ano após o nascimento de meu filho. Poucos meses depois, a escola teve de ser abandonada novamente, em virtude de eu não dispor nem de quem cuidasse da criança nem de acesso à vaga em creche pública, para que eu estudasse e concluísse os estudos. Esse projeto só se tornou possível quando quatro anos mais tarde, meu filho acessou a escola de Educação Infantil particular, o que me permitiu buscar a minha matrícula em curso supletivo, no qual completei a escolarização básica.

Sobre o convívio em família, qual não foi minha surpresa, já passados alguns anos, a postura de censura por parte de meus familiares retorna. Diante da minha decisão em começar a trabalhar, a retaliação gira em torno do argumento de que eu ficava todos os dias na rua e, por isso, meu filho não era criado por mim e que eu nem sequer pensava nele. Eu me defendia dizendo que era justamente o contrário: o ingresso no mundo do trabalho, e posteriormente na 
graduação, eram projetos de vida que, na minha visão, possibilitariam prover uma condição melhor ao meu filho. Mesmo assim, as recriminações perduravam em cobranças, que atuavam no sentido de fazer materializar uma maternidade que só seria admitida como correta se mantida sob o confinamento do lar e, que todo o meu tempo fosse tomado pelos cuidados para com o meu filho, o que, naturalmente, diante de todo o exposto, não era uma projeção de vida desejada e viável. Essa passagem encontra amparo e análise pelo olhar da obra $O$ conflito: $a$ Mulher e a Mãe da filósofa francesa Elisabeth Badinter (2011), que ponderou sobre a maternidade não ser a totalidade da existência das mulheres. A autora discorre sobre a abertura de "[...] uma diversidade de modos de vida, que suas mães não conheceram. Pode-se dar prioridade as ambições pessoais, gozar do celibato e de uma vida de casal sem filhos, ou satisfazer o desejo da maternidade com ou sem atividade profissional" (BADINTER, 2011, p.9). Badinter também aponta as contradições da maternidade contemporânea com certa 'liberdade' paradoxal das mulheres. Se por um lado o cuidado com a carreira, e assim, do espaço público, multiplicou as tarefas e responsabilidades maternas, por outro, a escolha ou não da maternidade também é uma responsabilidade com a qual a mulher terá que lidar. Desta forma, "dando fim à antigas noções de destino e de necessidade natural, ela traz para o primeiro plano a ideia de realização pessoal". De resto, essa perspectiva que alia “[...] a liberdade se revelou fonte de uma espécie de contradição. Por um lado, modificou sensivelmente a condição da maternidade, implicando o acréscimo de deveres em relação à criança que se decidiu pôr no mundo" (BADINTER, 2011, p.10).

Nessa direção, a psicóloga brasileira Diana Dadoorian (2003), ao escrever o texto Gravidez na adolescência: um novo olhar, nos revela que, ao se lançar na compreensão das questões envolvidas na gravidez das adolescentes brasileiras de classes populares, o enfoque comumente difundido considera indesejável a maternidade no período da adolescência, quase sempre, relacionada à desinformação e imaturidade. É pertinente salientar que a essa expectativa negativa atua o conceito do estigma, amplamente debatido no livro Do silêncio do lar ao silêncio escolar: racismo, preconceito e discriminação na educação infantil, da professora brasileira Eliane Cavalleiro (2006). O estigma é, conforme Cavalleiro (2006), o predomínio de uma visão negativa e preconceituosa sobre as pessoas negras, construída socialmente a partir da interiorização de identificação positiva da branquitude nas esferas socioculturais. Tal dinâmica constitui o cerne da discriminação racial, cuja atuação se dá por meio da socialização de imagens, precariamente elaboradas, que utilizam não somente as 
hostilizações individuais, mas operantes também pelas estruturas sociais, em sutis restrições da participação, como a invisibilização social e o silenciamento.

Considerando a maneira como o estigma atua nas expectativas sociais, construindo e estruturando o racismo, é possível identificar similaridades com o que é vivido pelas jovens mulheres mães, no que toca às expectativas sociais relacionadas à gravidez na adolescência. As jovens mães são visibilizadas como sujeitas, ora desacreditadas, ora como heroínas, se elas, apesar da indesejada experiência, conseguem vivenciar o desafio da maternidade. $\mathrm{O}$ estigma da gravidez na adolescência coexiste com o fato de que as adolescentes continuam engravidando, mesmo com essa "marca" negativa e com o concomitante acesso a métodos contraceptivos, difusão de conteúdo por meios de comunicação, livros, televisão, escola e outros. Logo, na análise de Dadoorian (2003), o fenômeno da maternidade na adolescência não pode ser mensurado desconsiderando, uma vez que seu significado extrapola a subjetividade, conforme afirma:

[...] a importância do significado individual da gravidez, que corre paralelo ao desejo universal de ter ou não ter um filho, bem como a noção de uma "gravidez social" determinada por fatores culturais e psicológicos que particularizam o significado da maternidade em adolescentes de classes populares (DADOORIAN, 2003, p.84).

Avaliando de maneira geral, Dadoorian (2003) pondera que os sentimentos envolvidos na maternidade são ambivalentes, desde o amor ao ódio, passando pela carência, cansaço ou rejeição. No que diz respeito a mim, a sensação era a de que minha história de infância se repetia, sendo eu, agora, ocupando o papel de protagonista como mãe-má-ausente, com o descrédito das pessoas atingindo o meu filho com maledicências, violentando a nós dois, como em outros tempos violentaram a mim e minha mãe. Retornam os sentimentos de injustiça e incompreensão, mediante atos e falas repassados de forma rude e desrespeitosa à mulher e à criança. Intimamente, eu só sabia dizer da angústia que sentia ao sofrer essas cobranças, ao lado das tentativas de correção de comportamento e da sobrecarga de adjetivos que desvalorizavam a mulher. Ao mesmo tempo, era muito confortante ver minha mãe se posicionando também contra essas posturas.

Cumpre acrescentar que muitos desses dilemas fazem parte dos enfrentamentos de mães de crianças pequenas, principalmente, quando essas passam a frequentar a Educação Infantil, uma vez que a escola representa o distanciamento físico da mãe. Esse é um dado presente nas falas das professoras da creche participante da pesquisa. Durante os encontros 
formativos, disseram que "- É um momento bem difícil tanto para a mãe quanto para o filho", e que "- Causa um grande impacto na vida da criança, pois ela sai do convívio direto com a mãe", o que denota um reconhecimento institucional que se concretiza no suporte oferecido durante o período da adaptação. Ao se inserirem na creche, mães e crianças são acolhidas e integradas ao cotidiano escolar de maneira gradativa, momento este que é norteado pelo vínculo amoroso mãe/criança.

Sobre esse conflito, Badinter (2011) assevera que, embora, a Psicologia e a Psicanálise do século XX já protestem contra "a concepção de maternidade-reflexo e de ilusão de adequação perfeita entre a mãe e a criança”, é uma grande ironia que, ainda nos dias de hoje, se observe um retorno a modelos essencialistas relacionados à maternidade, evocados pelos paradigmas de desenvolvimento, estudados também pela psicóloga britânica Érica Burman (2009). No instigante texto Desenvolvimento desejado? Contribuições psicanalíticas pra o antidesenvolvimento psicológico, Burman (2009) propõe uma releitura acerca da intensificação contemporânea do desenvolvimentismo psicológico, ligado aos modelos de desenvolvimento individual e econômico, utilizando-se de elementos da Psicanálise. Ainda que o desenvolvimento psicológico não seja temática abordada na tese, o trabalho da autora traz interrogações úteis ao escopo da pesquisa, ao criar condições para pensar de modo relacional os direitos das mulheres e os direitos das crianças. Burman (2009, p.271) pondera que

O agente por trás do desenvolvimento pode ter mudado no sentido de que o Estado-nação é, em alguns aspectos fundamentais, agora subordinado a corporações multinacionais e a ideia de que uma trajetória singular (trabalho ou carreira) de desenvolvimento dá lugar a configurações de lares e de relações de trabalho mais diversificadas, híbridas e fluidas (isto é, casuais, "precárias"), mas o projeto geral (do capitalismo global e de maximização) permanece o mesmo.

Isso equivale a dizer que, mesmo com a independência financeira das mulheres, a dominação masculina perante as mulheres se mostra presente, na forma de cobranças dos deveres para com os bebês e crianças pequenas, seja em casa ou no trabalho, corroborada pelas demandas das relações econômicas. Burman (2009) analisa que o efeito dessas cobranças está no perverso reforço da expectativa da "boa mãe", aquela que em tudo concorre para que as crianças se desenvolvam e acompanhem as expectativas e demandas dos sistemas econômicos. Diante de tal análise, também desenvolvida por Badinter (2011), podemos concluir que recai sobre as mulheres uma "suave tirania", na qual elas que se sentem 
abandonando suas crianças na escola, o que perversamente as distanciam da compreensão que a educação escolar é, também, um direito. Isso se dá pela maneira como as mulheres são demandadas na inserção do mercado global, que segue reproduzindo um olhar de exploração patriarcal, principalmente no modo como as crianças, também inseridas nas relações individualistas e de consumo, são interpeladas por um apelo desenvolvimentista e a uma dimensão de direitos, compreendidos numa fusão "do que é bom para elas" (BURMAN, 2009). Concordando com Burman (2009), que sinaliza sobre o esvaziamento de sentido entre os direitos e o desenvolvimentismo psicológico infantil, já que "o que é bom” para as crianças equivale à dedicação exclusiva da mãe, questionam-se aqui algumas facetas, ou contradições, do esvaziamento de sentido na citada relação: a responsabilização em ser uma "boa mãe", útil ao desenvolvimento psicológico das crianças, gera a invisibilidade de direitos adquiridos das mulheres, como o trabalho. Ao lado disso, há um empobrecimento na consolidação dos direitos das crianças pequenas, já que a produção de conhecimentos na escola tende a ser deslegitimada, em detrimento dos laços com a mãe, como observado em fala socializada em um dos encontros formativos: "quando uma criança que entra na creche, a família fica, assim: "-Coitadinho","

Entendo que aqui seja adequado reforçar que existe uma forte tensão e até, por vezes, o que se pode denominar como campo de disputa entre grupos e movimentos sociais, entre os direitos das mulheres e os direitos das crianças, que, a bem das relações democráticas, não deveriam ser percebidos como excludentes ou invisibilizadores, sob pena de incorrermos em outro esvaziamento de sentido. Os direitos das crianças existem - e precisam ser assegurados e ampliados a partir das mudanças e complexificação das relações sociais -, assim como os direitos das mulheres. Compreender a simultaneidade das duas esferas de direitos citadas, em suas nuances, intersecções e conflitos, tal como analisado pela cientista política belga Chantal Mouffe $^{6}$ (2003; 2005), torna o que seria um possível dissenso em um caminho favorável ao necessário movimento dialógico, em perspectiva agonística, que garante a democracia.

Compreendo que minha experiência pessoal faz, pelos conflitos vivenciados e descritos aqui, um triplo movimento em termos de estigmatização: a jovem-mãe-mulher, caracterizadas em dupla subordinação de gênero $^{7}$ à categoria geração. No que toca à especificidade das múltiplas formas de violência e discriminação que afetam as mulheres, a

\footnotetext{
${ }^{6}$ Tais pressupostos serão desenvolvidos no item relativos aos conceitos, situado no capitulo 1 , e ao longo da tese.
} 
reflexão de que a jovem-mãe-mulher é triplamente vulnerável foi suscitada pelo conceito da dupla subordinação de gênero, desenvolvido pelas professoras brasileiras Daniela Auad e Cláudia Lahni, no texto intitulado Cidadania democrática e homossexualidades: comunicação no combate à violência contra as mulheres lésbicas (2013), em que as professoras analisam como as categorias sociais - raça, classe, orientação sexual, entre outras - podem se combinar, acirrando uma relação de desigualdade, "a partir da consideração de vulnerabilidades relacionadas às variadas maneiras de ser mulher e jovem, lésbica e negra, idosa e pobre" (AUAD; LAHNI, 2013, p.151). Sendo assim, a tripla vulnerabilidade é construída a partir de um ideal de maturidade materna, que desqualifica a jovem enquanto mãe e enquanto mulher, numa especificidade de discriminação que pode ser lida como uma manifestação misógina, já que tal expectativa não atinge os homens.

Até a inserção na graduação, eu não tinha conhecimento de nenhuma formulação dos Feminismos, tampouco nenhum contato com algum movimento social ou organização que visibilizasse alguma discussão ou apoio aos problemas que eu enfrentava. Sem ter fontes para recorrer a esse conhecimento, também não ficava claro para mim o porquê de, em tom pejorativo, ser classificada como feminista. Esse enfrentamento pessoal corresponde às contundentes palavras da escritora inglesa Rebecca West, que em 1913 afirmou: "Eu mesma nunca cheguei a entender direito o que quer dizer feminismo: só sei que as pessoas me chamam de feminista toda vez que expresso sentimentos que me diferenciam de um capacho" (apud FALUDI, 2001, p.22).

Somente anos mais tarde, fui compreender que todos os movimentos de resistência à subordinação, imposta pelas variadas manifestações dos machismos, eram recebidos de forma negativa pelo fato de denunciar práticas que desumanizam e inferiorizam seres humanos, como as mulheres e também as crianças. Em sua obra Backlash: o contra-ataque da guerra não declarada contra as mulheres, a jornalista estadunidense Susan Faludi (2001) coloca as disputas pelos direitos e reconhecimento político e social das mulheres, amparadas pelos feminismos, evocando propositadamente termos militares, pois sim, elas enfrentam verdadeiras batalhas ao cobrar a igualdade de condições sociais e o exercício de liberdade sobre seus corpos e suas vidas.

As tensões que mobilizaram o direcionamento de minha sensibilidade à figura da mulher e da criança, obtido a partir de trajetória pessoal, ganhou espaço como objeto de estudo a partir da inserção na graduação em Pedagogia. As disciplinas cujo foco eram as crianças pequenas e as mulheres, pensadas sob o âmbito da carreira que escolhi exercer, 
possibilitaram elaborar melhor as causas e efeitos que os eventos ocorridos ao longo de minha vida podem impactar a Educação e as vivências das pessoas de modo geral. Os conteúdos referentes à Educação Infantil, principalmente aqueles atinentes às concepções de infância e as políticas educacionais que cuidavam das crianças pequenas, me permitiram acessar saberes importantes que diziam respeito às relações que fazem parte do cotidiano das crianças, sobretudo o olhar que as pessoas adultas destinam a elas e a dimensão da responsabilização por sua Educação. As obras de autoras feministas abordadas nas disciplinas que tratavam de Gênero e Educação eram contundentes em discutir as dinâmicas que buscam deter as mulheres somente em alguns nichos profissionais, ou no comprometimento de determinadas tarefas, como o cuidado das crianças e de outras pessoas, além de todo o caráter das construções sociais sobre as subjetividades que tratam das categorias gênero, raça, classe e geração, aspectos esses que estão presentes nas construções infantis, permeadas pelo social, como expõe a feminista inglesa Alison Jaggar (1997), no texto Amor e conhecimento: $a$ emoção na epistemologia feminista:

Pode-se perceber claramente que as emoções são socialmente construídas quando se ensina deliberadamente às crianças aquilo que sua cultura define como resposta apropriada a certas situações: ter medo de pessoas estranhas, gostar de comida temperada ou gostar de nadar em água fria. Num nível menos consciente, as crianças também aprendem o que sua cultura define como maneiras apropriadas para expressar as emoções que ela reconhece (JAGGAR, 1997, p.163).

Vale destacar que o reconhecimento dessas categorias de análise foram sendo relacionadas e nomeadas considerando os fenômenos políticos que atingem as mulheres e as crianças. E, assim, não mais de maneira intuitiva apenas, mas também com embasamento teórico desenvolvido em produções escritas, em contínuo aprofundamento, obtido ao acompanhar as discussões e atividades de pesquisa do Grupo de Estudos e Pesquisas Educação, Comunicação e Feminismos - Flores Raras, desde o ano de 2012.

A partir das temáticas debatidas em Grupo de Pesquisa, desenvolvo o meu trabalho de conclusão de curso ${ }^{8}$, buscando conhecer como as disciplinas destinadas a estudar a Educação Infantil abordam o tema gênero junto à formação de professoras. Realizado conjuntamente ao projeto de pesquisa Relações de Gênero nos cursos de Pedagogia: desafios e obstáculos de

\footnotetext{
${ }^{8} \mathrm{O}$ Trabalho de Conclusão de Curso consistiu em escrita no formato de artigo intitulado "Relações de Gênero e Educação Infantil: o antigo e não esgotado debate da Formação Docente nos cursos de Pedagogia". O trabalho foi desenvolvido sob a orientação da Prof. ${ }^{a}$ Dr. ${ }^{a}$ Daniela Auad no decorrer dos anos de 2012 e 2013 e foi apresentado no Seminário Internacional Fazendo Gênero 10 em modalidade pôster em 2013, na Universidade Federal de Santa Catarina.
} 
um percurso inacabado, o trabalho apontou as insuficiências sobre o debate das relações de gênero na escola junto às alunas da Faculdade de Educação da UFJF, embora questionamentos a esse respeito fossem recorrentes nas discussões das disciplinas que ministravam conhecimentos sobre a Educação Infantil.

Notadamente, os elementos pelos quais as questões de gênero se fizeram presentes nas passagens pessoais dessa pesquisadora também eram apontados pelas alunas da Pedagogia, como os comportamentos infantis, a preocupação com os cuidados e com expectativas de uma "moldura" social a ambos os sexos. Paralelo ao acesso das formulações das disciplinas da FACED, o trabalho também conheceu a iniciativa do projeto Crianças no Fazendo Gênero, que conta com espaço de acolhida das crianças que acompanham suas famílias no Seminário Internacional Fazendo Gênero. Esse espaço surge da demanda social das participantes do evento, e se revela como profícua oportunidade em apresentar às crianças outras vivências, ao passo que esse grupo pode se beneficiar da produção acadêmica desenvolvida e socializada no Núcleo de Desenvolvimento à Infância da Universidade Federal de Santa Catarina, espaço em que o saber é construído em debates que postulam uma Educação mais igualitária, valorizando dessa forma, tal como neste trabalho, uma perspectiva educacional não sexista, não racista, não homofóbica e que valorize os aspectos geracionais. Tal enfoque justifica a consideração do projeto Crianças no Fazendo Gênero como proposta reconstrutora concreta, que promove debates fundamentais de temas sociais junto às crianças, configurando-se como instância de respeito à criança-cidadã.

Seguindo esse mesmo fio condutor, a dissertação de Mestrado Relações de Gênero e Docência na Educação Infantil: interfaces entre políticas públicas e abordagens pedagógicas ${ }^{9}$ pesquisou como as questões de gênero são consideradas nos trabalhos pedagógicos da Educação Infantil na cidade de Juiz de Fora (MG), e considerou como referenciais os trabalhos de feministas e estudiosas de gênero (como Guacira Louro, Daniela Auad, Alison Tronto, Susan Bordo e outras), documentos orientadores da Educação e as publicações de caráter formativo disponibilizadas a professoras/es pelo Ministério da Educação, realizando debate desses conteúdos com professoras da rede do município de Juiz de Fora (MG), representantes da Secretaria de Educação e da Casa da Mulher, instituição de

\footnotetext{
${ }^{9}$ Dissertação cuja discussão consta publicada também em forma de artigos, na Revista Educação e Emancipação (PPGE/UFMA,2017) e na Revista de Ciências Humanas (PPGEDU/URI-FW,2018). Os dados obtidos em pesquisa também foram apresentados em congressos, na modalidade comunicação oral, a saber: Seminário Enlaçando Sexualidades (2015), na $2^{\text {a }}$ Conferência Internacional de Psicologia LGBT e campos relacionados: enfrentar o impacto da discriminação contra pessoas LGBT em todo o mundo (2016) e no $13^{\circ}$ Congresso Mundos de Mulheres e Seminário Internacional Fazendo Gênero 11 (2017).
} 
proteção voltada às mulheres vítimas de violência. O estudo indicou que a Educação Infantil é terreno nebuloso quando estudado sob a perspectiva de gênero. Na realidade pesquisada, há iniciativas que consideram os avanços sociais que dizem respeito à participação e cidadania das crianças, mas não são escassas as inseguranças com relação às maneiras de combate ao sexismo. Notadamente, esses impactos citados são reflexos da conjuntura política que manifesta-se contrária ao debate sobre as desigualdades sociais relacionadas à categoria gênero, apoiadas pelo conservadorismo religioso. Dessa maneira, se colocam permanentemente em tensão questões de cunho político que afetam a esfera democrática e as motivações das práticas da Educação e, de modo especial, da Educação Infantil (RAMOS, 2016).

As discussões propostas na dissertação foram apresentadas em congressos, na forma de comunicações orais, no Seminário Enlaçando Sexualidades (2015), na 2a Conferência Internacional de Psicologia LGBT e campos relacionados: enfrentar o impacto da discriminação contra pessoas LGBT em todo o mundo (2016) e no $13^{\circ}$ Congresso Mundos de Mulheres e Seminário Internacional Fazendo Gênero 11 (2017). O trabalho "Educação Infantil e Gênero: uma relação multifacetada e uma política não consolidada”, escrito em coautoria com a professora Daniela Auad, rendeu um texto completo publicado nos anais do citado evento. Ainda no ano de 2017, o trabalho "Gênero e educação infantil: um recorte possível e necessário no caminho para relações justas e democráticas" também obteve aprovação na modalidade Comunicação Oral na IV Semana da Faced IX Semana da Educação XII Seminário Anual de Pesquisa em Educação do PPGE, o que também rendeu uma publicação nos anais do evento.

Ao término do ano de 2017, no mês de dezembro, obtivemos aprovação do artigo "Educação, emancipação e feminismos possíveis: um olhar histórico sobre a igualdade de gênero na escola" na Revista Educação e Emancipação, periódico do programa de Pós Graduação em Educação da Universidade Federal do Maranhão (PPGE/UFMA). Esse artigo também foi escrito em coautoria com a professora Daniela, e com a professora Raquel Borges Salvador. Já em 2018, o texto "Gênero na Educação Infantil: (des)caminhos de uma política pública não consolidada", novamente em coautoria com Daniela Auad foi publicado na Revista de Ciências Humanas, que é vinculada ao Programa de Pós-Graduação em Educação da Universidade Regional Integrada do Alto Uruguai e das Missões - Campus de Frederico Westphalen - RS (PPGEDU/URI-FW). 
Motivada por essa conjuntura, o processo de pesquisa do Doutorado retoma as inquietações do Mestrado ao dialogar sobre uma Educação para a Democracia desde a Educação Infantil. Ao nos referirmos ao termo Educação para a Democracia, nos valemos dos escritos da socióloga brasileira Maria Victoria de Mesquita Benevides Soares (1996), autora de potente texto intitulado Educação para a Democracia. Nesse trabalho, a citada socióloga desenvolve e aproxima da realidade concreta os pilares essenciais à liberdade para a participação na vida pública, associada aos valores republicanos e a cidadania contemporânea, a saber: as liberdades civis, a tolerância, a participação política em vários níveis, a igualdade, a transparência e alternância no poder e o respeito à diversidade. Considerando esses pilares, nas palavras da autora, a Educação é entendida como “[...] a formação do ser humano para desenvolver suas potencialidades de conhecimento, de julgamento e de escolha para viver conscientemente em sociedade" (BENEVIDES, 1996, p.225), na qual é fundamental a formação intelectual, ética, moral e comportamental, concepção na qual a tese se ampara para dialogar sobre a democratização dos direitos das mulheres e os direitos das crianças pela Educação.

Acrescentando a isso as disposições legais ${ }^{10}$ existentes que prescrevem sobre a corresponsabilidade dos entes públicos e famílias na educação das crianças, a tese reafirma que percepções não discriminatórias são pilares de formação humana. Desse modo, o citado estudo busca o entendimento de uma Educação para a Democracia no ambiente da creche, buscando as falas de professoras e gestoras sobre os direitos das crianças e os direitos das mulheres mães, entremeadas às dimensões da importância indissociável do cuidar e educar, bem como de discussões que naturalizam - ou não- os fazeres destinados às crianças pequena.

\section{A- BASES TEÓRICAS: O QUE DIVULGAM AS FONTES BIBLIOGRÁFICAS}

Diante da conjuntura exposta e dos objetivos buscados, se torna importante para a tese aqui desenvolvida tentar compreender os sentidos da maternidade. Para tal usamos como referência as obras Um amor conquistado - $O$ mito do amor materno e $O$ conflito: a Mulher e a Mãe de Elisabeth Badinter, publicados respectivamente nos anos de 1985 e 2011. Também relacionados a essa temática, buscamos acessar os sentidos do cuidado - care - e para tal a obra $O$ cuidado infantil no século XXI: Mulheres malabaristas em uma sociedade desigual de Eleonor Faur (2014) foi adotada como referência, além de textos como O trabalho de cuidado

\footnotetext{
${ }^{10}$ Artigos 205 da Constituição Federal de 1988, e 227 do Estatuto da Criança e do Adolescente, de 1990, já mencionados no presente texto.
} 
- comparando Brasil Bélgica e Japão e o livro Cuidado e Cuidadoras - as várias faces do care, de Helena Hirata $(2016 ; 2002)$ que tratam especificamente do cuidado como trabalho, o que impacta diretamente as atividades das mulheres.

Para as formulações dos Feminismos, tanto na perspectiva histórica de modo geral quanto no diálogo desses movimentos com as demandas de creches foram adotados como referência textos de Maria Amélia Almeida Teles, como Feminismo no Brasil: trajetórias e perspectivas (2003) e A participação feminina na luta por creches! (2015). Sobre a história dos movimentos feministas no continente europeu e na América Latina foram adotados como referência o manuscrito Primeira infância e emancipação das mulheres: para a refundação do serviço público ${ }^{11}$ (Petite enfance et émancipation des femmes: pour la refondation du service public) escrito pelas feministas Anne Bucas-Français, Jacqueline Penit-Soria e Nicole Savey em 2006, e o texto Feministas na América Latina: de Bogotá a San Bernardo, de autoria de Nancy Saporta Sternbach, Marysa Navarro-Aranguren, Patricia Chuchryk e Sonia E. Alvarez (1994). Nesses materiais contam muitas informações sobre as creches em muitos países, incluindo o Brasil. Para adensar os debates sobre as creches brasileiras e nos países do nosso continente, também nos baseamos no texto $O$ movimento de mulheres e abertura política no Brasil: o caso da creche (1984) de Fúlvia Rosemberg e no trabalho de Roselane Fátima Campos (2011) "Política pequena" para as crianças pequenas? Experiências e desafios no atendimento das crianças de 0 a 3 anos na América Latina. Ainda sobre a educação das crianças, foi adotado como obra de referência também o livro "Educação Infantil no Brasil", de autoria de Patrícia Corsino, Maria Fernanda Resende Nunes e Vital Didonet (2011).

Sobre a maternagem, a tese considera como referência o livro Psicanálise da Maternidade: uma crítica a Freud a partir da Mulher, de Nancy Chodorow (1990) e os trabalhos de Dagmar Meyer, intitulados Uma politização contemporânea da maternidade: construindo um argumento (2005) e Discursos que (con)formam corpos grávidos: da medicina à educação física (2011) que versam sobre a educação para além do advento biológico do gerar. A questão do gênero e suas construções na escola será abordada pela ótica do livro Educar Meninas e Meninos: Relações de Gênero na escola (2006), de Daniela Auad, bem como a tese Relações de gênero nas práticas escolares: da escola mista ao ideal de coeducação (2004), da mesma autora. Ainda sobre esse tema foi adotado também o livro Gênero e Sexualidade na Educação (1997) de Guacira Lopes Louro e o emblemático texto de

${ }^{11}$ A leitura do referido texto se deu por meio de tradução livre, realizada por esta pesquisadora. $\mathrm{O}$ texto original, em francês, não possui tradução para o português. 
Joan Scott (1995) Gênero: uma categoria útil de análise histórica. Também foi tomado como referência o texto de Suzanne Mollo-Bouvier, de nome Transformação dos modos de socialização das crianças: uma abordagem sociológica (2005), uma vez que essa tese compreende que as interações têm papel fundamental à vida coletiva. Já os conceitos e concepções que constituem a base dessa pesquisa (Feminismos, Cidadania, Democracia e outros) foram abordados sob a ótica de livros como Gênero, Patriarcado e Violência, da feminista brasileira Heleieth Saffiotti (2011), e Ensinando a transgredir: a educação como prática de liberdade, da feminista estadunidense bel hooks (2013), bem como o Dicionário Crítico do Feminismo (2009). Também utilizamos as obras da feminista belga Chantal Mouffe intituladas Sobre o político (2015) e Por um modelo agonístico de democracia (2005), e os textos Educação para a Democracia (1996) e Cidadania e Democracia (1994) da pesquisadora brasileira Maria Victória de Mesquita Benevides. Em reconhecimento aos trabalhos dessas e outras autoras citadas na tese, visibilizamos o nome completo, a formação e a área de atuação das pesquisadoras, quando da primeira menção desses referenciais no texto. A essas obras se somam as discussões obtidas por meio de levantamento bibliográfico, cujas formulações são evocadas na construção dos capítulos da tese. Passemos a expor o percurso e critérios adotados quando da seleção bibliográfica.

Foram adotadas como fontes de busca os anais eletrônicos de congressos e portais digitais que divulgam pesquisas na forma de artigos, trabalhos, publicações, teses e dissertações acerca da temática de interesse, a saber: Anais do Seminário Internacional Fazendo Gênero, Seminário Internacional Desfazendo Gênero e Seminário Enlaçando Sexualidades. Também foram consideradas publicações disponíveis na Biblioteca Digital Scielo, no Banco de Teses e Dissertações da CAPES, na Biblioteca online da ANPED e da Revista Educação em Foco. Tendo em vista que a citada revista faz parte de publicações organizadas pela Universidade Federal de Juiz de Fora (MG), município de realização dessa pesquisa.

Para adensar o debate proposto, foi realizada coleta de referenciais teóricos que nos permitiram descortinar o pano de fundo no qual a questão de pesquisa de insere. $\mathrm{O}$ procedimento inicial adotado foi a leitura dos resumos dos trabalhos atinentes ao tema da pesquisa. A leitura dos resumos permitiu a essa pesquisadora fazer uma seleção dos trabalhos a serem lidos na íntegra. A partir da seleção final dos textos, procedemos à confecção de resenhas para auxílio teórico na escrita do trabalho. Ao todo, foram selecionados 38 (trinta e oito) textos relativos à temática da pesquisa. 
Tais fontes foram consultadas, uma vez que noticiam produções acadêmicas, estudos e observações desenvolvidos junto à área da Educação. Os anais dos citados congressos foram considerados pela mesma razão e também por serem meio de divulgação de diálogos que nem sempre se estendem no âmbito das pós-graduações, mas que concorrem igualmente para o objetivo de uma busca bibliográfica, que é recolher subsídios de debate para com a área do objeto de pesquisa. A pesquisa dos aportes teóricos teve como recorte temporal os últimos cinco anos (2012 a 2017). Esse intervalo de tempo foi adotado tendo em vista a ocasião da culminância das discussões sobre a implantação das escolas de tempo integral no Brasil, consolidada pelo Programa Mais Educação (BRASIL, 2012), já que tal iniciativa disponibilizou a proposta de implantação da escola de tempo integral de maneira sistematizada a nível nacional. O tempo integral não é tema de debate desse tema, mas consideramos pertinente a disponibilização do fator tempo nas creches como garantia de acesso aos direitos de cidadania da mulher. $\mathrm{O}$ desenvolvimento das buscas e organização dos quantitativos, bem como a leitura dos resumos dos trabalhos selecionados que resultam nesse levantamento bibliográfico teve início no mês de maio do ano de 2017 e terminou no mês de fevereiro do ano de 2018.

A coleta nesses materiais se deu por meio de emprego da combinação de palavraschave relacionadas à questão de pesquisa. Foram utilizados os seguintes termos de busca: Educação Infantil; Cuidado; Gênero; Tempo Integral; Educação Infantil e Gênero; Educação Infantil e Cuidado; Educação Infantil e Tempo Integral. A princípio também adotamos as palavras-chave Maternagem e Feminismos, mas essas palavras não constaram em pesquisas nas fontes adotadas. A pesquisa bibliográfica se realizou primeiramente buscando resultados gerais das pesquisas relacionadas à Educação Infantil. Em um segundo momento, a palavra-chave Educação Infantil foi empregada combinada a outras, no intuito de alinhar os resultados obtidos com os interesses da presente pesquisa. Dos resultados obtidos dessa fase da busca, mediante leitura dos resumos dos trabalhos, classificamos os trabalhos pelo tema principal, dividindo-os em categorias a partir das temáticas pesquisadas, bem como de suas áreas de conhecimento e produção, tipo de trabalho e ano de publicação. Tomando como base essa categorização, realizamos a seleção dos trabalhos a serem lidos na íntegra. Explanadas as etapas do processo de coleta bibliográfica, passamos à exposição dos resultados obtidos.

Ao inserirmos a palavra-chave Educação Infantil nos anais de congressos e portais online de divulgação de pesquisa, foi apurado que no período de 2012 a 2017 foram 
divulgados nove trabalhos no Seminário Internacional Fazendo Gênero e outros nove no II Seminário Internacional Desfazendo Gênero. Já nas edições pesquisadas do Seminário Enlaçando Sexualidades constaram oito trabalhos apresentados no ano de 2015 e dois no ano de 2013, perfazendo o subtotal de 28 artigos.

Ainda apresentando resultados de pesquisa referentes à Educação Infantil, as bases de dados da ANPED acusaram 181 trabalhos, enquanto que o Banco de Teses e Dissertações da CAPES dispõe de 144.172 produções acadêmicas. A Revista Educação em Foco publicou um trabalho no ano de 2013, outro no ano de 2012, um na edição 2015-2016 e outro na edição do ano de 2016. E por fim, a plataforma Scielo conta com 643 publicações dedicadas às crianças pequenas. Diante de números de tão grande vulto, a partir desse momento passamos a empregar a palavra-chave Educação Infantil em associação com outras palavras no intuito de refinar os resultados. Utilizando a expressão de busca Educação Infantil e Gênero, consta nas publicações da ANPED um trabalho apresentado no ano de 2013 e dois no ano de 2015. Essa mesma expressão encontrou na plataforma Scielo sete artigos publicados no ano de 2017, outros seis no ano de 2016, quatro em 2015, sete em 2014, outros sete em 2013 e sete em 2012, totalizando 38 produções. O Banco de Teses e Dissertações da CAPES apresentou sete resultados, todos datados no ano de 2016. Somadas aos trabalhos selecionados nos anais dos congressos, chegou-se ao montante de 76 (setenta e seis) estudos, entre artigos, teses e dissertações que pesquisam a Educação Infantil sob o viés do gênero. Desses 76 trabalhos, 59 estudos são da área da Educação. Constam ainda trabalhos da área da Fonoaudiologia (4), Psicologia (4), Medicina (3), Educação Física (2), Sociologia (2), Ciências Humanas (2), Saúde Pública (1) e Literatura (1).

Em relação às temáticas exploradas, os textos abordam as questões de gênero junto a dimensões históricas da Educação Infantil, destacando-se o aspecto da docência. A docência também é abordada sob o viés do gênero relacionada à formação inicial e continuada, no que toca às representações sociais partilhadas por professoras e professores, influências de discursos conservadores e midiáticos e os reflexos dessas questões nas práticas pedagógicas. Alguns trabalhos enfocam somente a docência masculina na Educação Infantil. O gênero também é apontado como relevante elemento na socialização escolar infantil, nas relações familiares e na esfera do trabalho, impactando especialmente as mulheres no que tange aos cuidados e responsabilidades parentais. As mulheres também são o público-alvo em pesquisas que tratam dos cuidados na perspectiva da saúde alimentar, especialmente na gestação e no acompanhamento dos cuidados da saúde infantil. Além disso, há trabalhos que discutem a 
maneira com que o tema gênero aparece em obras literárias, filmes, cantigas, livros para a infância e vídeos, e como esses materiais concorrem para a construção das subjetividades. Por fim, constam também estudos que situam o gênero apenas como critério de classificação quantitativa das pessoas participantes das ações e/ou investigações divulgadas.

A palavra-chave Maternidade foi tema de sete trabalhos nos anais do Seminário Fazendo Gênero, um trabalho no Seminário Desfazendo Gênero, três no Seminário Enlaçando Sexualidades do ano de 2015 e dois no mesmo evento no ano de 2013, totalizando 13 artigos publicados. O Banco de Teses e Dissertações da CAPES apontou 3.494 trabalhos referentes à Maternidade, ao lado de 1.492 títulos na plataforma Scielo. Na biblioteca online da ANPED consta apenas um trabalho. A Revista Educação em Foco não divulgou artigos relacionados à maternidade. Como já mencionamos anteriormente, para refinarmos o número de pesquisas ao tema da tese, tornamos a filtrar a busca bibliográfica, utilizando desta vez a expressão Maternidade e Educação Infantil limitando a pesquisa ao período compreendido do ano de 2012 a 2017. Chegou-se a 4 publicações no Scielo, sendo três do ano de 2016 e uma do ano de 2013. Na plataforma CAPES aparece somente um trabalho, datado do ano de 2012. Contudo, este não está disponível para consulta por ser anterior à Plataforma Sucupira ${ }^{12}$. Já na ANPED não existem trabalhos com a combinação das palavras Educação Infantil e Maternidade. Dessa forma, o resultado geral é de dezoito trabalhos. Desse total, a área das Ciências Sociais foram responsáveis pela publicação de 3 trabalhos, ao lado do campo da Antropologia (3), seguidas pelo Direito (2), Educação (2), Serviço Social (2), Psicologia (2), Literatura (1), Saúde (1), Medicina (1) e História (1).

Mediante a leitura dos resumos dos trabalhos encontrados, as produções sobre a Maternidade versam sobre as questões dos direitos, as redes de auxílio, o advento da violência, questões relativas à sexualidade e as relações familiares e conjugais em contextos socioeconômicos diversos. O sexismo e o aborto são temas recorrentes nas pesquisas assim como a exploração da figura materna em livros de literatura.

A próxima palavra-chave considerada foi Cuidado. O cuidado foi tema de debate de cinco trabalhos do Fazendo Gênero, de um trabalho no Enlaçando Sexualidades 2015 e de outros dois no Enlaçando Sexualidades 2013. Não foram encontrados resultados com essa palavra-chave no Seminário Desfazendo Gênero. Na Plataforma Scielo a palavra-chave

\footnotetext{
${ }^{12}$ A Plataforma Sucupira é uma ferramenta de informações, análises e avaliações do Sistema Nacional de Pós Graduação (SNPG). Ela disponibiliza em tempo real informações e processos sobre todo o SNPG.

Fonte: http://www.capes.gov.br/avaliacao/plataforma-sucupira. Acesso em 03/02/2018.
} 
cuidado aparece em 11.464 artigos, e em 17.475 teses e dissertações do Banco da CAPES. A Revista Educação em Foco não divulgou trabalhos com o tema cuidado. A Biblioteca online da ANPED contabiliza 12 trabalhos discutidos sobre a questão do cuidado, e nenhum deles se insere no recorte temporal da pesquisa. Para restringir esses altos resultados nas bases Scielo e CAPES, novamente recorremos à combinação a outra palavra-chave. Dessa vez, a expressão Cuidado e Educação Infantil chegou a dois trabalhos disponíveis no Banco da CAPES, sendo um datado do ano de 2013 e outro publicado em 2015. Já na plataforma Scielo estão disponíveis 52 trabalhos que versam sobre o cuidado na Educação Infantil. Considerando esses 52 trabalhos, procedemos a uma nova filtragem, combinando a expressão Educação Infantil e Cuidado à palavra-chave Gênero. A expressão Educação Infantil, Cuidado e Gênero apontou o total de cinco trabalhos. Desses 5 artigos, dois foram publicados no ano de 2017, um em 2014 e outros dois no ano de 2013.

Logo, as produções selecionadas nos anais dos congressos e nas bases de dados citadas sobre a questão do cuidado perfazem o montante total de 15 textos. Desses 15 trabalhos, o campo da Psicologia analisa o aspecto do cuidado em 3 trabalhos, a mesma quantidade que a área da Educação. Outros dois trabalhos são do ramo da Sociologia, um da Antropologia, um do Serviço Social e um da Saúde Coletiva. A Medicina dedicou esse foco em um trabalho, bem como a Enfermagem e as Ciências Sociais. O cuidado é abordado em estudos que tratam sobre a questão da parentalidade considerando diversos contextos sociais, em discussões que envolvem as classes sociais, o âmbito escolar e a saúde. Os textos têm como principal público as crianças e mulheres, estas enfocadas em distintas gerações e orientações sexuais, como as mulheres LBT.

A última palavra-chave considerada foi Tempo Integral. Essa palavra-chave não figura como debate na edição do Seminário Fazendo Gênero e do Desfazendo Gênero. Também não constam trabalhos que abordem esse tema nas duas edições do Seminário Enlaçando Sexualidades, nem na Revista Educação em Foco. No entanto, foram encontrados sete trabalhos na Biblioteca da ANPED, 681 teses e dissertações no Banco da CAPES e 181 artigos na Plataforma Scielo. Ao utilizar a expressão Tempo Integral e Educação Infantil, chegamos ao quantitativo de seis artigos no Scielo, duas pesquisas no banco da CAPES e um trabalho apresentado nas reuniões da ANPED. Dos 6 trabalhos selecionados na Scielo, dois foram publicados no ano de 2017, um em 2015, outro em 2014, um em 2013 e outro em 2012.Os trabalhos disponíveis na CAPES são um do ano de 2017 e um do ano de 2016. O único trabalho que consta na Biblioteca da ANPED é do ano de 2015. Somando-se os 
resultados obtidos em todas as fontes pesquisadas, o total é de nove trabalhos que tratam do Tempo Integral. Desses resultados, apuramos que sete desses estudos foram desenvolvidos na área da Educação, um pertence às Ciências Humanas e o último da Psicologia. Pudemos observar que esses estudos abordam o tempo integral em termos de concepções políticas e de direito à Educação. A formação docente também é questão importante, ao lado das possibilidades de desenvolvimento infantil e de outras maneiras de uso dos espaços escolares.

A presente pesquisa bibliográfica procurou delinear um primeiro panorama do que é dito sobre Educação Infantil, Maternidade, Gênero, Cuidado e Tempo Integral. Para cumprir esse objetivo, o primeiro momento da pesquisa selecionou para leitura, mediante a utilização de palavras e expressões-chave, um total de 169 pesquisas. Após o acesso ao resumo desses trabalhos, o próximo movimento da presente busca bibliográfica foi realizar a seleção dos estudos atinentes ao embasamento da tese, a serem lidos na íntegra. Para essa seleção, foram adotados os seguintes critérios de exclusão: (1) trabalhos repetidos; (2) estudos que não contenham no título as expressões primárias relativas à questão de pesquisa; (3) trabalhos de áreas que não dialogam com a questão de pesquisa; (4) produções que não abordam o públicoalvo (crianças e mulheres), conforme os quantitativos abaixo:

Quadro I: Detalhamento de exclusão de trabalhos - pesquisa bibliográfica (Critérios utilizados e dados quantitativos)

\begin{tabular}{|l|c|}
\hline Trabalhos repetidos & 24 \\
\hline Trabalhos sem menção às palavras-chave da pesquisa & 15 \\
\hline Trabalhos que fogem ao tema de pesquisa & 77 \\
\hline Trabalhos que não consideram o público alvo & 15 \\
\hline Total de trabalhos excluídos & 131 \\
\hline
\end{tabular}

Fonte: Autoria da pesquisadora.

Ao supor que esses critérios atendam ao objetivo de circunscrever os debates referentes ao tema de pesquisa, finalmente chegamos ao total de 38 (trinta e oito) títulos a serem considerados como aportes teóricos da escrita da tese (VIDE APÊNDICE 1). Desses 38 trabalhos, dois deles são teses de doutorado, quatro dissertações de mestrado e vinte e nove artigos. Trinta e dois pertencem à seara da Educação, um do Serviço Social, um da Sociologia, um da área do Direito, um da Antropologia, um das Ciências Humanas, um da Psicologia e um da História.

Iniciando a leitura da seleção de artigos que compõem a pesquisa bibliográfica, o artigo das professoras brasileiras Daniane Caminero e Rosana Baldalotti (2013) - disponível 
nos anais do Seminário Internacional Fazendo Gênero 10 - ao enfocar as concepções e práticas sobre a infância considera a premissa de que existem diferentes visões construídas socialmente sobre a infância, o que enseja as autoras a acessar as mudanças dessas visões ocorridas ao longo da história, buscando compreender de que forma as transformações societárias, culturais e educacionais têm interferido na forma como professores da Educação Infantil concebem essa categoria na atualidade em suas práticas pedagógicas. Nessa mesma direção, o artigo das também professoras brasileiras Girlane Martins Machado e Karyne Dias Coutinho (2015) - que consta nos anais do Seminário Enlaçando Sexualidades - versa sobre a idealização das figuras da criança e da professora na Educação Infantil presentes nas práticas desse nível de ensino, bem como as evidências da presença de elementos que remetem às relações de gênero e seus estereótipos. A motivação do estudo reside no desconforto dos professores em lidar com os questionamentos e sentidos que as crianças manifestam, quando o foco são o gênero e a sexualidade. Tal dinâmica é permeada pelo sentimento, por parte dos professores, em passar referências concebidas como "normais" e "saudáveis", o que muitas vezes se atrela à práticas de silenciamento da diversidade sexual e a reprodução de estereótipos de gênero.

Com o mesmo foco, o artigo das professoras brasileiras Kátia Batista Martins, Andressa Helena de Lima e Luciene Aparecida Lima - também figurando no Seminário Fazendo Gênero 10 - traz relato sobre uma realidade escolar mineira que desenvolveu atividades junto à Educação Infantil, visando a abordagem sobre o respeito às diferenças de gênero e sexualidades, com vistas a problematizar o papel das interações como via de construção de identidades, principalmente na infância.

Cabe aqui ressaltar que a constância observada nesses trabalhos, referente ao trato das subjetividades não abordam a Educação infantil do ponto de vista dos direitos das mulheres e das crianças, além de não mencionarem as lutas dos movimentos sociais com essa finalidade. Nossa reflexão, a partir desse dado, é a de que a perspectiva da presente tese - os direitos dos grupos acima mencionados - transita por uma lacuna das produções teóricas sobre o tema Gênero e Educação Infantil. As demais produções vêm compondo o movimento de escrita a seguir, embasando, ao lado das obras de referência, a construção dos capítulos.

\section{B- APROXIMAÇÃO DO CAMPO: METODOLOGIA DA PESQUISA}

A presente pesquisa investigou a maternagem na creche, pelo caráter político da Educação Infantil como via de promoção de direitos e relações não-sexistas desde as 
infâncias, localizando as relações de maternagem e cuidado como promotoras diretas dos Direitos da Crianças e dos Direitos das Mulheres. Os dados foram obtidos a partir de realização de encontros formativos, em uma creche do município de Juiz de Fora (MG), a partir de aplicação de dinâmicas, em cada momento de interação com as docentes.

O foco de interesse foi conhecer como se dá o diálogo da escola com as mulheres, bem como conhecer as práticas que dizem respeito à dignidade da criança-cidadã e também da mulher. Tais práticas foram analisadas à luz das obras de referência, das prescrições dos documentos legais, dos estudos de referência e pesquisas selecionados na busca bibliográfica. $\mathrm{O}$ enfoque dado às interações observadas se volta para uma ideia de práticas constituintes de cidadania. Explicando melhor: foi observado se o tom dos diálogos, assim como a escuta e a tomada de providências e/ou decisões contribuem/concorrem para o respeito à cidadania da criança e também a da mulher, de modo a assegurar direitos já conquistados e, mais ainda, de inaugurar novos direitos, quando - e se - for o caso. A tese pretende contribuir na discussão sobre o exercício de direitos de cidadania de crianças e mulheres via Educação Infantil, em uma Educação não sexista, o que pode beneficiar a sociedade como um todo, uma vez que é passível de ser um dos caminhos de combate às desigualdades de gênero.

A proposta de trabalho retratado na tese se define como uma pesquisa qualitativa, produzida em pesquisa-ação, pois participante e ativa no contexto pesquisado, em uma abordagem de pesquisa-formação. A pesquisa qualitativa, é entendida aqui nos moldes da professora britânica Rosaline Barbour (2009), considera os contextos examinando-se as interações em suas múltiplas manifestações. Assim sendo, a presente pesquisa se utiliza da combinação metodológica, de pesquisa bibliográfica e estudo documental, em uma primeira fase, para na segunda parte da pesquisa, ou seja, a ida a campo utilizar-se de encontros formativos com a equipe de educadoras da creche a fim de construir reflexões sobre os direitos das crianças e das mulheres. A dinâmica de organização dos encontros formativos inspirou-se nos instrumentos dos grupos focais ${ }^{13}$, em reuniões que as participantes socializam suas opiniões. A terceira fase do estudo se lançou à interpretação dos dados de campo por meio de estudo comparativo, com o propósito de recolher subsídios que sejam úteis à discussão sobre os direitos de cidadania das crianças e das mulheres. Essa proposta de trabalho foi organizada em um projeto de pesquisa que, ao ser submetido ao Comitê de Ética e

${ }^{13}$ A princípio, a metodologia da etapa do campo de pesquisa foi desenhada enquanto grupo focal. Mediante considerações da banca de qualificação, consideramos mais significativa a proposta da pesquisa-formação, na qual as contribuições das participantes pudessem ser debatidas, refletidas e ressignificadas, por meio de materiais de estudos ofertados em cada encontro, constituindo possibilidade de formação profisssional 
Pesquisa com Seres Humanos da Universidade Federal de Juiz de Fora (UFJF) obteve parecer favorável à sua execução ${ }^{14}$, tendo início no mês de março do ano de 2019 , e término no mês de dezembro do mesmo ano.

A pesquisa bibliográfica, mediante a necessária ampliação do repertório de leituras sobre o tema e as categorias propostas é fundamental ao debate com a área do objeto de pesquisa. Nesse sentido, a análise documental também é admissível, uma vez que os documentos educacionais nacionais e municipais estabelecem orientações aos trabalhos realizados nas escolas. Além disso, eles servem como ferramenta de análise da "[...] dimensão política que envolve os processos educativos direcionados aos indivíduos". Desta maneira, a leitura de documentos é importante para se descortinar como estes são/foram constitutivos das ações que se materializam nas atividades educativas dirigidas ao público-alvo dessas políticas (DAMICO; KLEIN, 2012, p. 70). Consideraremos também como apoio legal os documentos da Constituição Federal de 1988 e o Estatuto da Criança e do Adolescente de 1990, que serão analisados em suas seções destinadas à Educação, ponderando sobre o que é dito com relação aos direitos e responsabilidades de provimento.

É importante notar que a concepção de Educação para a Democracia, norteadora dessa tese, compreende o conceito da Cidadania Ativa. Formulado pela socióloga Maria Victoria de Mesquita Benevides Soares. A Cidadania Ativa consiste em aperfeiçoar mecanismos de democracia, ao ampliar os canais de participação para além dos existentes, seja de modo direto, na forma da participação do povo, como em manifestos ou plebiscitos, ou de modo indireto, a partir da Educação Política, que é causa e consequência da democracia e da cidadania. A partir desse conceito, a tese compreende que é possível, se for o caso, que o movimento de pesquisa em interlocução à instituição pesquisada possa contribuir em discutir e visibilizar alguma situação de desrespeito aos direitos das crianças ou dos direitos das mulheres.

Os encontros formativos contaram com a mobilização dos saberes docentes das educadoras da creche sobre os direitos das mulheres e os direitos das crianças. O saber docente é conceito pesquisado desde os anos de 1980, tendo como grande expoente as análises do professor Maurice Tardif. Conforme o autor, em seu livro Saberes docentes e formação profissional (2002) os saberes docentes dizem respeito às habilidades, o saber-fazer, as competências e conhecimentos, tanto teóricos quanto constitutivos das práticas escolares,

\footnotetext{
${ }^{14}$ A autorização do Comitê de Ética e Pesquisa com Seres Humanos da Universidade Federal de Juiz de Fora (UFJF) à execução da presente pesquisa foi deferida em 05/09/2018 e está registrada no parecer de número 2.876 .738 .
} 
em suas efetivas mobilizações no trabalho diário da/o professora/or. Ao lado disso, Tardif interpreta os saberes docentes a partir de uma formação mais ampla e dialógica a outras realidades sociais, humanas e organizacionais nas quais os profissionais estão mergulhados, para além da escola.

Tardif classifica a dinâmica de construção dos saberes docentes a partir da noção do "polimorfismo do raciocínio", que revela que professoras e professores decidem suas formas de proceder baseando-se em diferentes raciocínios, como a indução, analogia, dedução ou abdução, conforme sua inscrição na construção de sua carreira, incluindo a perspectiva histórica e temporal, o que denota uma flexibilização da atividade docente (TARDIF, 2002). A partir da análise do autor, nos parece significativa a utilização de uma metodologia que mobilize os olhares das educadoras para com questões que toquem as mulheres e as crianças, tanto por serem o público ao quais os trabalhos pedagógicos são direcionados, quanto por dizerem respeito a vivências sociais que afetam as mulheres também fora da escola, bem como as relações da Educação com tais fenômenos. Ao lado disso, conhecer essas dinâmicas, por esses vieses, se aproxima com o movimento de análise do Feminismo Interseccional, que considera e contrasta as interferências e impactos de categorias sociais diversas nas relações que afetam as mulheres, como a classe social, a raça, a idade, a regionalidade, e outras, o que nos parece significativo a obter uma interpretação consistente e ampla da realidade e do objeto de estudo da tese.

Conforme o texto Formação de professores, saberes docentes e práticas educativas: a qualidade da educação infantil como centralidade, da professora brasileira Dirléia Fanfa Sarmento, em conjunto com os professores Paulo Fossati e Fernando Gonçalves (2012, p.122), o encontro formativo é um espaço “de reflexão e articulação teórico-metodológica [...] processo se efetiva com o acompanhamento dos pesquisadores e demais profissionais que tematizam conteúdos formativos específicos", a fim de propor reflexões sobre os fazeres pedagógicos cotidianos, permeados pelos direitos do público que acessa a creche.

O modelo formativo está fundamentado em quatro pilares que se interrelacionam dialogicamente: auto-hetero observação e análise da relação educativa; identificação de necessidades e projeção de estratégias de formação individual e coletiva; intervenção no contexto educativo; e investigação sobre a prática educativa. Um dos objetivos da observação e análise da relação educativa é possibilitar a emergência de uma prática cada vez mais sólida e adequada ao real através do ciclo de observar para diagnosticar, diagnosticar para avaliar, avaliar para decidir e decidir para atuar. A complexidade da relação educativa convida a refletir sobre e tentar compreender as diferentes variáveis que interferem em sua qualidade. Dessa 
forma, a observação (seja auto ou hetero-observação) e a partilha de seu conteúdo viabiliza a avaliação, que, por sua vez, se entendida num sentido formativo, possibilita a identificação de temáticas a serem incluídas no projeto formativo de cada um dos atores que atuam no contexto educativo e a projeção de estratégias de formação individual e coletiva (SARMENTO; FOSSATI; GONÇALVES, 2012, p.121).

A preparação dos encontros formativos conta com roteiro semiestruturado organizado a partir dos elementos mais comuns apontados pelas obras de referência. Estruturamos 6 (seis) encontros, com questões e materiais de estímulo para o desenvolvimento dos momentos de debate. Os encontros formativos reuniram a equipe pedagógica de uma creche de Juiz de Fora (MG) em rodas de conversa sobre a maternidade, o cuidado e a Educação. Foram selecionados materiais de apoio para as discussões, como vídeos e textos. Os encontros foram registrados em gravações de áudio, cujas transcrições subsidiaram a análise do campo, bem como material escrito produzido nas atividades. Os encontros se realizaram uma vez por mês e tiveram a duração de 40 (quarenta) minutos a 1 (uma) hora cada.

Os dois primeiros encontros foram rodas de conversa. No primeiro encontro foram feitas as apresentações das participantes e os questionamentos iniciais se deram em torno do que as participantes pensam sobre a maternidade e o acesso às creches. Foi solicitado que elas escrevessem um pequeno comentário sobre o tema. Logo após, a pesquisadora convidou as participantes a se manifestarem verbalmente, e conforme o diálogo foi se desenvolvendo, ocorreram intervenções mediadoras, a fim de estender e/ou detalhar os comentários e outros esclarecimentos sobre o debate em questão. As participantes foram convidadas a pesquisarem sobre a creche enquanto espaço democrático aos direitos das mulheres e crianças, apresentando os resultados dessa pesquisa, e a discussão proposta focou sobre a perspectiva geral da creche em relação aos direitos do público que atendem.

$\mathrm{O}$ debate do terceiro encontro apoiou-se em uma entrevista ${ }^{15}$ da feminista brasileira Maria Amélia de Almeida Teles sobre a luta das mulheres no Brasil, e também um vídeo ${ }^{16}$ cujo tema é a importância das creches para as mulheres. Esse encontro gerou reflexão sobre os reflexos do atendimento da Educação Infantil na vida das mulheres mães. O quarto encontro também se amparou em conteúdo de vídeo ${ }^{17}$ (Era uma vez outra Maria), e discutiu sobre os conservadorismos das relações de gênero e seus efeitos na vida das mulheres, o aspecto da construção social dos comportamentos e expectativas sociais. Também foi

\footnotetext{
${ }^{15}$ Fonte: https://www.youtube.com/watch?v=V2IxvxThvRU.

${ }^{16}$ Fonte: https://www.youtube.com/watch?v=LHvz4ivG5nw\&t=110s.

${ }^{17}$ Fonte: https://www.youtube.com/watch?v=-ezAQj3G4EY.
} 
disponibilizada uma resenha do livro Educar meninos e meninas: relações de gênero na escola (AUAD, 2006), material a ser debatido no encontro posterior. O quinto encontro contou com a apresentação do conteúdo do citado livro, seguido de conversa com as participantes que colocaram suas impressões sobre as manifestações das relações de gênero em seu cotidiano e no cotidiano da creche.

O sexto encontro debateu os elementos contidos em vídeo da feminista nigeriana Chimamanda Adichie ${ }^{18}$, a saber: a valorização humana, importância da Educação em promover valores igualitários; impactos do sexismo, a agência da criança e a importância da socialização. Finalizando os encontros formativos, as principais discussões foram retomadas, sendo solicitado às participantes que elas escrevessem suas impressões sobre dos direitos das crianças e das mulheres via creche.

Posteriormente, as informações coletadas foram analisadas comparativamente com as fontes teóricas e documentais no que se aproximam e/ou se distanciam das disposições legais e também do acúmulo de pesquisa sobre a Educação Infantil, os direitos das crianças e das mulheres. O estudo comparativo é um método que "[...] é amplamente utilizado nas ciências sociais, pois auxilia a perceber as diferenças inclusive entre grandes sistemas, como os de cunho político ou cultural" (GIL, 2008, p.17). Deste modo, esperamos promover reflexões sobre o debate político que envolve a creche, a Educação, as práticas de maternagem e o exercício da cidadania.

Sobre a instituição participante da etapa de coleta de dados, foi selecionada uma creche em Juiz de Fora (MG) da rede pública de ensino. Em Juiz de Fora, o trâmite passa pela Secretaria de Educação, que procura auxiliar indicando instituições que não estejam participando de pesquisas, a bem de não prejudicar ou sobrecarregar as rotinas das escolas. A creche selecionada faz parte de um projeto amplo de assistência à crianças em condições de vulnerabilidade. No município pesquisado, a instituição existe desde o ano de 1984. De acordo com informações disponíveis no Catálogo Social ${ }^{19}$ da cidade, a instituição vincula-se à Secretaria de Assistência Social, e relaciona-se com a proteção social especial, já que

\footnotetext{
${ }^{18}$ Fonte: https://www.youtube.com/watch?v=EC-bh1YARsc

${ }^{19}$ O Catálogo Social da cidade de Juiz de Fora (MG) é um material desenvolvido pela Secretaria de Assistência Social da Prefeitura Municipal, que divulga informações sobre as redes de proteção social disponíveis no município, disponibilizando a "relação ordenada das entidades, instituições e equipamentos socioassistenciais, bem como informações de localização e descrição dos tipos de serviços oferecidos por essas instituições.

Fonte: https://www.pjf.mg.gov.br/secretarias/sds/arquivos/publicacoes/catalogo_social.pdf. Acesso em $17 / 04 / 2019$.
} 
promove o acolhimento institucional e a assistência pedagógica e social. Sobre a dimensão da proteção, o citado documento destaca:

As situações de risco demandarão intervenções em problemas específicos e/ou abrangentes. Nesse sentido, é preciso desencadear estratégias de atenção sociofamiliar que vissem a reestruturação do grupo familiar e a elaboração de novas referências morais e afetivas, no sentido de fortalecê-lo para o exercício de suas funções de proteção básica ao lado de sua autoorganização e conquista de autonomia. A Proteção Social Especial é desenvolvida nos Centros de Referência Especializado de Assistência Social (CREAS). É a modalidade de atendimento assistencial destinada a famílias e indivíduos que se encontram em situação de risco pessoal e social por ocorrência de abandono, maus-tratos físicos e/ou psíquicos, abuso sexual, o uso de substâncias psicoativas, cumprimento de medidas socioeducativas, situação de rua, situação trabalho infantil, entre outras (JUIZ DE FORA, 2012).

O entendimento da proteção e assistência em combate a situações de vulnerabilidade social, mencionado pelo catálogo social do município de Juiz de Fora, é acompanhado pelos critérios de seleção para as vagas das creches (vide anexo 1), o que parece esboçar a preocupação do poder público em combater as ocorrências de descumprimento das obrigações de cuidado para com as crianças pequenas, por meio do acesso à creche. Contudo, ressaltamos que, para além da dimensão da proteção social, a dimensão da Educação precisa ser privilegiada, o que vem sendo debatido por essa tese, por numerosas pesquisadoras dessa área e também por movimentos sociais. Esse direito fundamental deve ser considerado na garantia de vagas a todas as crianças! Ao findar essa seção do texto, passamos a debater as concepções fundadoras e norteadoras dessa tese, além de recuperar os contextos sociais e políticos dos direitos das mulheres e das crianças, pensados sob o viés de uma Educação Infantil emancipadora, democrática e que busca assegurar direitos, uma vez que possuímos legislação pertinente e um longo caminho trilhado ao avanço do reconhecimento social desses grupos. 


\section{CONCEITOS E SUAS TRAJETÓRIAS: MATERNAGEM, CUIDADO E EDUCAÇÃO}

Este capítulo debate os conceitos admitidos como a base teórica que se destina a refletir sobre a questão de pesquisa. Serão apresentados os muitos percursos percorridos pelas mulheres ao batalhar pela visibilização da atuação das creches, como política pública e espaço de educação e cidadania, bem como, os enfoques sobre a temática do Cuidado e Educação na Educação Infantil. Além dos textos que servem de marco legal, uma vez que o presente estudo traz a perspectiva dos direitos das mulheres e dos direitos das crianças, serão apresentadas as questões que compõem o panorama sobre as desigualdades que afetam mulheres e crianças nos contextos social e político, com ênfase na demanda pelos direitos de acesso aos serviços das creches. A partir de dados coletados em obras de referência, o propósito deste capítulo é tecer considerações sobre a conjuntura que compõe a pesquisa e debater como é possível entrelaçar a ideia da maternagem e sua relevância com as relações das profissionais das creches com as crianças pequenas. Esse item tem o propósito de explicitar a abordagem desta tese, baseada em noções e concepções que merecem a nossa apreciação tanto da perspectiva lega, quanto da legitimidade. Trata-se de um capítulo que delineia e precisa os chamados conceitos-chave do estudo, partindo de enfoques sobre as mulheres e as crianças. Os conceitos, a saber, são: Gênero; Criança; Maternidade; Maternagem; Cidadania; Cidadania Incompleta; Cidadania Ativa; Cuidado; Feminismos, Justiça Social e Democracia.

Inicialmente, apresentamos a definição sobre os grupos de pessoas que são foco dessa pesquisa, as mulheres e as crianças. Do ponto de vista legal, ao se referir às pessoas cidadãs brasileiras, a Constituição Federal de 1988 traz em sua seção Dos direitos e Garantias Fundamentais que:

Art. $5^{\circ}$ Todos são iguais perante a lei, sem distinção de qualquer natureza, garantindo-se aos brasileiros e aos estrangeiros residentes no País a inviolabilidade do direito à vida, à liberdade, à igualdade, à segurança e à propriedade, nos termos seguintes: (EC n. $\left.{ }^{\circ} 45 / 2004\right)$

I - homens e mulheres são iguais em direitos e obrigações, nos termos desta Constituição; [...] (BRASIL, 1988, p.13, grifo nosso).

A Lei Maior coloca homens e mulheres como iguais no gozo dos direitos e obrigações, bem como das liberdades individuais, os chamados Direitos Civis, cujo artigo $5^{\circ}$ expressa "Todos são iguais perante a lei, sem distinção de qualquer natureza, garantindo-se aos brasileiros e aos estrangeiros residentes no país a inviolabilidade do direito à vida, à liberdade, 
à igualdade, à segurança e à propriedade". Contudo, considerando as especificidades que afetam as mulheres em especial, como a maternidade, a Constituição estabelece no capítulo Dos Direitos Sociais, no artigo $6^{\circ}$, que:

Art. $6^{\circ}$ São direitos sociais a educação, a saúde, a alimentação, o trabalho, a moradia, o transporte, o lazer, a segurança, a previdência social, a proteção à maternidade e à infância, a assistência aos desamparados, na forma desta Constituição. (EC n. ${ }^{\circ}$ 26/2000, EC n..$^{\circ}$ 64/2010 e EC nº 90/2015. BRASIL, 1988, p.18- grifo nosso).

Sobre a proteção à maternidade, no mesmo capítulo, o sétimo artigo menciona em subitem que as mulheres usufruam de "[...] XVIII-licença à gestante, sem prejuízo do emprego e do salário, com a duração de cento e vinte dias;". O artigo, também, regulamenta que os homens acessem a "[...] XIX- licença-paternidade, nos termos fixados em lei..." (BRASIL, 1988, p.18). A ambos estão resguardados o direito de "[...] XXV- assistência gratuita aos filhos e dependentes desde o nascimento até 5 (cinco) anos de idade em creches e pré-escolas...” (BRASIL, 1988, p.19). Sobre a figura da criança, o capítulo VII - Da Família, da Criança, do Adolescente, do Jovem e do Idoso (EC n. ${ }^{\circ}$ 65/2010) - atribui as seguintes responsabilidades:

Art. 227. É dever da família, da sociedade e do Estado assegurar à criança, ao adolescente e ao jovem, com absoluta prioridade, o direito à vida, à saúde, à alimentação, à educação, ao lazer, à profissionalização, à cultura, à dignidade, ao respeito, à liberdade e à convivência familiar e comunitária, além de colocá-los a salvo de toda forma de negligência, discriminação, exploração, violência, crueldade e opressão. (EC n. ${ }^{\circ}$ 65/2010)

$\S 1$ o $O$ Estado promoverá programas de assistência integral à saúde da criança, do adolescente e do jovem, admitida a participação de entidades não governamentais, mediante políticas específicas e obedecendo aos seguintes preceitos:

I-Aplicação de percentual dos recursos públicos destinados à saúde na assistência materno-infantil;

II - Criação de programas de prevenção e atendimento especializado para as pessoas portadoras de deficiência física, sensorial ou mental, bem como de integração social do adolescente e do jovem portador de deficiência, mediante o treinamento para o trabalho e a convivência, e a facilitação do acesso aos bens e serviços coletivos, com a eliminação de obstáculos arquitetônicos e de todas as formas de discriminação (BRASIL, 1988, p.132, grifo nosso).

A preocupação com a Criança pequena, enquanto cidadã, é corroborada pelo Estatuto da Criança e do Adolescente - ECA (BRASIL, 1990), que dispõe sobre "a proteção integral à criança e ao adolescente" (Art. $\left.1^{\circ}\right)$, regulamentando que é, perante a lei brasileira, considerada 
criança a pessoa que possuir até 12 (doze) anos incompletos. Além de retomar o princípio da prioridade de proteção, atendimento e foco de políticas públicas, o ECA assegura, no art. $3^{\circ}$ que à criança e ao adolescente tenham "[...] todas as oportunidades e facilidades, a fim de lhes facultar o desenvolvimento físico, mental, moral, espiritual e social, em condições de liberdade e dignidade" (BRASIL, 1990, p.9), o que as coloca como sujeitos de direitos. Ao lado disso, o ECA, ao iluminar as necessárias interações para a promoção do desenvolvimento das crianças, coloca as crianças como atores sociais dessa construção de desenvolvimento. Assim sendo, consideramos oportuno situar que a tese concebe a Criança "como sujeito social, que participa de sua própria socialização, assim como da reprodução e da transformação da sociedade" (MOLLO-BOUVIER, 2005, p. 393).

$\mathrm{O}$ fato de as crianças serem afetadas pelo entorno social, em sua guarda e Educação, coloca em evidência também as famílias. Embora as situações de guarda compartilhada estejam em crescente ascensão após a promulgação da Lei 13.058/2014 ${ }^{20}$, ainda é massivo o número de crianças sob a responsabilidade exclusiva das mulheres, seja ela a mãe ou outras mulheres da família. A referida lei não assegura que os pais, homens, irão exercer sua paternidade, desdobrando-a em cuidados. A lei dá o direito, mas não transforma as socializações masculinas, que continuam a ser guiadas pelas desigualdades de gênero. Ao lado disso, há indícios do uso de leis para aprofundar a violência de ex-maridos contra mulheres e filhas/os, frutos de anteriores relações ${ }^{21}$. Conforme divulgação do Instituto de Pesquisa Econômica Aplicada - IPEA, no ano de 1995, 23\% dos domicílios eram chefiados por mulheres. Em 2015, esse número salta a $40 \%{ }^{22}$.

Além de questões ligadas ou não à conjugalidade, historicamente os cuidados com a família são delegados às Mulheres, por conta da maternidade. Podemos observar que o rompimento com formas essencialistas de conceber a maternidade se relacionam ao Feminismo e ao conceito gestado em seu bojo: o Gênero. Esse permitiu às mulheres debaterem com propriedade sobre as dinâmicas produtoras de desigualdades que evocam a

\footnotetext{
${ }^{20}$ A lei $\mathrm{n}^{\mathrm{o}} 13.058$, promulgada em 22 de dezembro de 2014 altera os art. $1.583,1.584,1.585$ e 1.634 da Lei no 10.406, de 10 de janeiro de 2002 (Código Civil), para estabelecer o significado da expressão "guarda compartilhada" e dispor sobre sua aplicação. Fonte: http://www.planalto.gov.br/ccivil_03/_Ato2011-2014/2014/Lei/L13058.htm. Acesso em 20/01/2019.

${ }^{21}$ Sobre as desigualdades impostas pela lei da alienação parental, a publicação da socióloga Ana Liési Thurler intitulada $A$ discussão sobre "Estatuto das Famílias" e a onda conservadora no Legislativo brasileiro oferta maior profundidade sobre o tema e riqueza de dados, sobre os quais não é possível se dedicar no momento.

${ }^{22}$ Fonte:

http://www.ipea.gov.br/portal/index.php?option $=$ com_content\&view=article\&id=29526\&catid=10\&It emid $=9$
} 
diferenciação e hierarquização das pessoas pelas expectativas acerca de seu sexo biológico ou, nas palavras da historiadora estadunidense Joan Wallach Scott, "[...] o caráter fundamentalmente social das distinções baseadas no sexo" (1995, p.72) perpassado pela historicidade, interpretação de significados, organizações e instituições sociais. Há aqui um caráter político nessa questão, em uma dinâmica de forças em disputa pelo poder patriarcal. O patriarcado, debatido amplamente pela professora brasileira Heleieth Saffioti (2011, p.44) "[...] é o regime da dominação-exploração das mulheres pelos homens".

No entanto, a mesma autora nos alerta que o patriarcado não é uma categoria analítica como o gênero, mas sim um fenômeno social que se transforma. "[...] o patriarcado não abrange apenas a família, mas atravessa a sociedade como um todo" (SAFFIOTI, 2011, p. 47).

Citamos aqui essa definição, pois o que as feministas buscam é a igualdade social entre todas as pessoas e o patriarcado é uma das forças que afetam essa busca, porque advém dela a referência androcêntrica que tenta exercer, dentre outros poderes, o controle sobre a sexualidade feminina (SAFFIOTI, 2011), o que se entrelaça diretamente com as expectativas sociais relacionadas à mulher incumbindo-a da maternidade e dos cuidados das crianças. Sobre a busca de igualdade social, a professora brasileira Guacira Louro (1997) analisa que

[...] as justificativas para as desigualdades precisariam ser buscadas não nas diferenças biológicas (se é que mesmo essas podem ser compreendidas fora de sua constituição social), mas sim nos arranjos sociais, na história, nas condições de acesso aos recursos da sociedade, nas formas de representação. (LOURO, 1997, p. 22).

De maneira ampla, o entendimento conservador sobre o gênero coloca as pessoas, desde a infância, em contato com expectativas sobre as subjetividades, limitando de maneira sexista as vivências e práticas sociais, por meio da educação nos múltiplos espaços de convivência, inclusive na escola, no mercado de trabalho e principalmente, nas relações interpessoais com atravessamentos de diversas ordens, como debatido pela feminista brasileira Maria Amélia de Almeida Teles (2003).

[...] existe uma opressão específica a todas as mulheres, independente de classe social, raça/etnia, orientação sexual, faixa etária, origem geográfica e qualquer hemisfério que esteja localizado seu país. Essa opressão se manifesta tanto em nível das estruturas como das superestruturas (ideologia, política, religião, filosofia) (TELES, 2003, p.51). 
As bases da abordagem feminista, ao explicitar o combate às desigualdades sociais, se insere na perspectiva da Justiça Social. O professor Kenneth Zeichner (2008) localiza a Justiça Social como agenda presente nas políticas e na educação desde a década de 1980, nas preocupações com o futuro do planeta ante as diversas desigualdades sociais. Ainda que veiculada em meio a Educação por muitas denominações, variando conforme o enfoque (sócio-reconstrucionista, antirracista, multicultural etc.), a perspectiva da Formação de Professores para a Justiça Social, segundo Zeichner (2008), pretende formar professoras e professores para contribuírem nas mudanças sociais, na escola e na sociedade como um todo, a partir da promoção da equidade no ensino, uma vez que tal iniciativa tende a contribuir na diminuição das injustiças na sociedade fora dos sistemas de ensino, em problemáticas como o acesso à moradia, à saúde, ao emprego, às questões de discriminação de gênero, o racismo, dentre outras, que ao representarem um acesso desigual, configuram-se como um desrespeito aos direitos e à democracia. Não se trata de responsabilizar nem centralizar a educação pela reversão das desigualdades sociais, que demandam ações conjuntas e mudanças estruturais muito amplas e profundas. Mas de entender, assim como Zeichner (2008), que a educação pode oferecer contribuições importantes nessa agenda, transformando as realidades. Diante dessa conjuntura desafiadora, o que defendemos é a perspectiva de uma justiça social pelo enfoque feminista na Educação ${ }^{23}$.

E é nesse grande conjunto de categorias sociais envolvendo o gênero, a classe, a raça e a geração que residem as resistências, debates, ações e proposições dos Feminismos. Nesse trabalho, a definição de Feminismos é entendida tal como concebida por Teles (2003).

O conceito de feminismo adotado refere-se a um movimento político que questiona as relações de poder, a opressão e a exploração de grupos de pessoas sobre as outras, particularmente da dominação sobre a população feminina. Contrapõe-se radicalmente ao poder patriarcal que sobrevive ainda nos dias de hoje, sutilmente ou não, disfarçado em "igualdade", "competência" e "liberdade de disputa e concorrência". Considera que existe uma opressão específica a todas as mulheres, independente de classe social, raça/etnia, orientação sexual, faixa etária, origem geográfica e em qualquer hemisfério que esteja localizado seu país. Essa opressão se manifesta tanto em nível das estruturas como das superestruturas (ideologia, política, religião, filosofia). Assume formas diversas, conforme classes e camadas sociais, relações étnico-raciais, orientação sexual e faixa etária e também sofre mudanças ao longo da história da sociedade humanas (TELES, 2003, p.51-52).

${ }^{23}$ Diante de tal conjuntura, surge outro questionamento: tal enfoque feminista na Educação seria o correspondente a uma Pedagogia Feminista? Esse questionamento que a tese nos suscita não será esgotado pelo estudo, mas certamente, motiva novas pesquisas e reflexões. 
Aprofundando sobre o bojo construtor das desigualdades sofridas pelas mulheres no meio social descritas por Teles (2003), Auad (2003) aponta que:

\begin{abstract}
A dependência econômica e psicológica não foi construída, durante séculos e séculos, sobre dados biológicos irrefutáveis que comprovassem a fragilidade das mulheres. Essa relação construiu-se de modo inverso: as características biológicas das mulheres é que foram associadas à inferioridade (AUAD, 2003, p.23).
\end{abstract}

Essa grande proposta esbarra em um olhar sistêmico, o que nos direciona ao último e grande conceito, que é a Democracia. Apoiando-nos em Maria Victoria Benevides, a democracia é entendida como "o regime político fundado na soberania popular e no respeito integral aos direitos humanos" (BENEVIDES, 1996, p.225). A citada autora nos coloca essa definição considerando tanto as assertivas consideradas "antigas", quanto as mais atuais ponderações que situa a democracia em um contexto republicano, cidadão e liberal, manifestações próprias das sociedades contemporâneas. A democracia, deste modo, se afina com os objetivos dos feminismos nas suas diferentes épocas. De maneira geral, o que esses movimentos tinham, e tem em mente, é a defesa dos direitos das mulheres pela contestação os ordenamentos sociais e políticos, que historicamente se colocam como sexistas e excludentes.

O princípio da igualdade é há muito debatido por autoras como Scott (2005) que situa o papel das contingências como determinantes para sua aplicabilidade social e/ou política. Assim como as relações de gênero impõem perspectivas preconceituosas e inferiorizantes às mulheres, o advento da escravidão é determinante para a estigmatização das pessoas negras, fomentando atos e exclusões racistas até a época atual. Aspectos biológicos, étnicos e culturais geralmente se associam a uma categoria de pessoas com características específicas, o que permite o reconhecimento de um grupo. Outros elementos também podem se associar em termos de pertencimento, como determinadas profissões, afinidades políticas ou ideológicas. No entanto, Scott (2005) nos alerta que os mesmos elementos que definem os indivíduos como grupo (mulheres, homens, negras, negros, crianças, indígenas, jovens, professoras, entre outros), ao expressarem uma relação de igualdade, também estabelecem a relação da diferença. No âmbito do político, o reconhecimento ou a negação da diferença nasce do princípio que Chantal Mouffe chamou de exterioridade constitutiva, em seu livro Sobre o político (2003). A manifestação desse princípio ocorre a partir da oposição de ideias. Mouffe observa que os posicionamentos políticos, na busca por legitimidade, assumem um caráter de natureza pernicioso, para além da oposição em si. Ideias divergentes são admitidas com um 
contorno negativo por parte de seus emissores/receptores. As diferenças políticas se organizam numa divisão pautada entre o nós/eles, e carregam um estado de ânimo que é a expressão do binômio amigo/inimigo, conhecido pelo fenômeno do antagonismo político (MOUFFE, 2003).

Mouffe nos chama a atenção para um aspecto que é determinante para o bom andamento dos processos democráticos: "a política democrática não pode assumir a forma de confrontação amigo/inimigo sem levar à destruição do ente político" (MOUFFE, 2003, p.50). A autora compreende que, ao não reconhecer como legítimos outros pontos de vista sobre quaisquer matérias políticas, se desconsidera o pluralismo social, meio e instrumento da soberania popular, pilar democrático já mencionado por Benevides (1996). Além de um desrespeito que se configura como uma desigualdade, Mouffe (2003) enfatiza que é impossível estabelecer um conjunto harmonioso que exclua os conflitos, justamente pela existência de interesses e realidades diferentes.

O liberalismo tem de negar o antagonismo porque, ao pôr em primeiro plano o incontornável momento de decisão - no sentido profundo de ter de decidir em um terreno indefinido -, o que o antagonismo revela é o próprio limite de qualquer consenso racional. Na medida em que o pensamento liberal adere ao individualismo e ao racionalismo, sua cegueira frente ao político em sua dimensão antagonística não é, portanto, mera omissão empírica, mas uma omissão constitutiva (MOUFFE, 2003, p.11).

As divergências são a expressão do político e um apelo democrático. Mouffe (2003) entende que o consenso deve ser racional e democrático, e fundado nas pretensões de legitimidade e justiça, o que só pode ser alcançado pelo debate vibrante, ou seja, pelo dissenso. O movimento pós-democrático atual, analisado pela autora, identifica que o consenso predominante propõe formas de moderação das paixões políticas, "matando" os debates, o que ela identifica como "núcleo vital da democracia". É esse entendimento que norteia a defesa de um modelo democrático agonístico por Mouffe, o qual identificamos como vital à construção da democracia, em que as paixões coletivas - compostas pelos anseios e interesses de todas as pessoas - possam se expressar, sem que tais manifestações sejam deslegitimadas ou menosprezadas, como é o que, comumente, ocorre com as demandas relacionadas às creches e pelo conhecimento e Educação produzidos nela.

No artigo intitulado Casa e mercado, amor e trabalho, natureza e profissão: controvérsias sobre o processo de mercantilização do trabalho de cuidado, a professora 
brasileira Nadya Araújo Guimarães (2016) destaca as especificidades do cuidado no Brasil como trabalho, considerando outros marcadores além do gênero:

[...] o afluxo feminino ao mercado tem uma dupla faceta, assentada num marcador de classe (Sorj e Fontes, 2013), que se imbrica consubstancialmente com evidências das desigualdades raciais. Esse movimento se nutre tanto do afluxo das mulheres escolarizadas, majoritariamente brancas, que competem por postos melhor remunerados $\mathrm{e}$ protegidos, como do das mulheres escassamente escolarizadas, majoritariamente negras, que formam o enorme contingente de mais que 7 milhões de trabalhadoras domésticas, correspondendo a perto de $20 \%$ da força de trabalho feminina presente hoje no mercado brasileiro (GUIMARÃES, 2016, p.68).

Da mesma maneira que mulheres não podem (ou não deveriam) ser percebidas como naturalmente ligadas à função de serem mães, coerentemente as crianças devem (ou deveriam) ser tratadas com o prestígio social já prescrito na Lei Maior brasileira, como cidadãs. O preceito da Cidadania, de acordo com a socióloga belga Bérengère MarquesPereira é entendida "[...] como uma prática de conflito ligada ao poder e às lutas para o reconhecimento dos atores considerados protagonistas de reivindicações legítimas. Ela é também ligada a uma prática consensual de participação e representação, bem como de formação das políticas públicas" (MARQUES PEREIRA, 2009, p.39).

Com o foco na dimensão cidadã das mulheres e das crianças, e considerando as desigualdades que perpassam a consolidação dos direitos, se torna necessária a reflexão sobre um quadro de Cidadania Incompleta. O termo Cidadania Incompleta vem sendo empregado atualmente nas áreas jurídica e de geografia financeira. A área jurídica localiza a cidadania incompleta em ponderações que envolvem a concomitância entre a privação, ou precariedade, de acesso a alguns direitos, ao lado do usufruto de outros (MEDEIROS, 2017), dinâmica essa afinada com as análises do historiador José Murilo de Carvalho, considerado o precursor dessa perspectiva no Brasil. Já a área da geografia financeira focaliza os impactos advindos da política no cotidiano, em conjunto com o fenômeno da financeirização, na produção de riquezas materiais e imateriais (SILVEIRA, 2017). Tais definições são pensadas em um contexto mais amplo, cuja discussão se situa numa cidadania plena, vivenciada de maneira democrática. Tendo como recorte principal a democracia e gênero, a dimensão da cidadania se coloca, nos moldes atuais, em um olhar inclusivo, tendo em vista a incompatibilização de uma sociedade democrática com as dívidas históricas com os grupos subalternizados, e logo, vulnerabilizados por essa condição, como é o caso das mulheres e das crianças. 
A socióloga brasileira Clara Araújo (2012) explora as tensões envolvidas na perspectiva da democracia no enfoque da política no que tange às mulheres, que visa tão somente à justiça, esclarecendo que o gênero atua como estruturante e elemento desafiador, na dinamicidade da democratização em tempos de globalização. A partir da representatividade política plural, a autora questiona a atuação e a presença das mulheres, explorando os movimentos de luta que contribuíram à (re)organização na vida social. "Isso é muito importante em se tratando das mulheres, do seu lugar e do seu não lugar, tanto na formulação moderna dos requisitos da e para a cidadania como nas formas de inserção atuais" (ARAÚJO, 2012, p.152).

As mulheres, conforme Araújo (2012, p.151), ao lutarem pela cidadania política, carregam com elas não somente o modelo inclusão/exclusão, dinâmica mais pragmática sobre como se pensa ou se concebe por cidadania, mas retratam a "característica inerentemente processual da democracia e as possibilidades e potencialidades da cidadania nesse contexto". A afirmação da autora é pertinente ao pensarmos em todos os momentos históricos, sociais e políticos rememorados ao longo da pesquisa, pois foram com entendimentos distintos que a noção de cidadania no Brasil, em especial a de mulheres e crianças, foi sendo construída, por vezes negada e também reconstruída. Por essa razão, Araújo (2012), ao analisar a dimensão da cidadania, para além do conceito, localiza a importância dos indivíduos e os seus lugares enquanto sujeitos na democracia. Essa assertiva é obrigatória uma vez que, na democracia, o "eu" interage com o "nós". Em outras palavras, isso corresponde a dizer, como Araújo (2012, p.153): “o sujeito mesmo da democracia, o cidadão, só se visibiliza num coletivo chamado de povo. Mas esse só existe por meio de representações aproximativas e sucessivas de si mesmo". A despeito das contradições e conflitos que (sempre) surgem dessa dinâmica, Araújo aponta que um caminho possível seja justamente esse: o abraço sem crítica desse caráter ambíguo, como apregoa o moderno ideário de justiça. Tal caminho se alinha com um modelo agonístico de democracia, tal como nos ensina Mouffe (2003).

No que diz respeito às crianças, tal como as mulheres, elas sofreram com o apagamento em muitos períodos, seguidos por uma visibilização como um "problema" social até atingirem o status de cidadãs. No entanto, sua cidadania é atingida no problemático acesso à Educação, pela rede insuficiente de creches, e também pelos mesmos índices de pobreza, falta de infraestrutura e acesso aos serviços básicos que atingem suas mães e famílias.

Com o mesmo foco sobre as práticas democráticas mencionadas por Marques Pereira (2009), a tese pensa um caminho para que a cidadania plena seja consolidada também pela via 
da Educação. Nessa direção, Maria Victoria Benevides, ao aprofundar-se sobre as dimensões necessárias ao ato concreto do exercício da cidadania, nos apresenta - em publicação intitulada Cidadania e Democracia (1994) - o conceito de Cidadania Ativa, que consiste em ação "[...] que institui o cidadão como portador de direitos e deveres, mas essencialmente criador de direitos para abrir novos espaços de participação política", nos quais a participação popular atue em conjunto aos mecanismos institucionais nos debates de interesse público (BENEVIDES, 1994, p.9). Esse conceito, que não deve ser perdido de vista, é crucial à presente pesquisa e a uma Educação para a Democracia. Ele convive com as tensões das especificidades das atividades que as mulheres assumem por conta das expectativas sociais e históricas, como já exposto no trabalho.

A questão da Maternidade - idealizada ao longo dos tempos - é conceito há muito debatida por feministas, que propõem necessárias releituras à luz das inúmeras dinâmicas que se envolvem no espectro dessa relação social. Da abnegação e do amor incondicional propostos pela mítica religiosa, as feministas Françoise Collin e Françoise Laborie (2009) em verbete do Dicionário Crítico do Feminismo - definem a Maternidade como advento que "[...] constitui, ao mesmo tempo, uma especificidade valorizada - o poder de dar a vida, uma função social em nome da qual reivindicar direitos políticos ou direitos sociais, e uma das fontes da opressão" (COLLIN; LABORIE, 2009, p.133). Logo, a Maternidade contemporânea se constitui numa tensão social identificada ainda na década de 1980, que é...

[...] a de viver-para-si-e-com-as-crianças, implicando não somente uma verdadeira repartição do trabalho e das responsabilidades domésticas entre pai e mãe, mas também a possibilidade de se afastar do caráter opressor da geração biológica, acedendo simultaneamente à geração simbólica. Esta, ao permitir às mulheres que falem em seu próprio nome e escolham seus modos de parentesco e de filiação, pode ser portadora da liberdade (COLLIN; LABORIE, 2009, p.138).

Concebida dessa maneira, ao ser analisada pelo viés da Sociologia, a admissão da Maternidade como compulsória começa a ser analisada e repensada como em elaborações do livro Mães arrependidas, escrito pela israelense Orna Donath. Em recente entrevista concedida à Revista $\mathrm{Cult}^{24}$, a socióloga pondera sobre os reflexos do ideário que as sociedades construíram sobre a maternidade, personalizadas pelos sentimentos de 23 mulheres israelenses que lidam com sentimentos ambíguos ao ocuparem a posição de mães. $\mathrm{Na}$ realidade pesquisada, as mulheres se sentem ressentidas com a sobrecarga de trabalho e

\footnotetext{
${ }^{24}$ Fonte: https://revistacult.uol.com.br/home/orna-donath-entrevista/ Divulgada em 06/08/2018.
} 
responsabilidades e como elas se sentem em constante conflito com a romantização da figura da mãe, principalmente aquelas que não desejam sê-lo, como explica a citada socióloga:

Desde a infância nos dizem que a maternidade é a essência da vida das mulheres e que cada uma de nós vai sentir que todas as dificuldades no processo de criação dos filhos valerão a pena - não importa quem ela seja, o que seja capaz de fazer, quais tenham sido seus outros sonhos e desejos, e em quais circunstâncias econômicas e de saúde ela se encontre. Também nos disseram que a maternidade faria "tudo ficar bem", como se você fosse renascer como uma pessoa que mereça ser chamada de "mulher"; renascer como uma pessoa que mereça ser tratada como parte de algo. As mães que participaram do meu estudo, aquelas que genuinamente quiseram ser mães, descobriram mais tarde que a maternidade não apenas não resolveu questões e problemas anteriores, como criou ainda mais caos na vida delas. Depois da maternidade, sentiram-se limitadas e alienadas (ORNA DONATH, 2018).

Embora, com as valiosas contribuições dos movimentos feministas acerca do direito à reprodução, Orna Donath assevera que ainda estamos percorrendo o caminho necessário a transgredir as construções conservadoras sobre a maternidade, "[...] já que não estamos encarando nossos mundos emocionais de forma binária”.

Há uma linda frase de Ulrich Beck e Elizabeth Beck-Gernseim que diz que vivemos em uma era de "não mais, mas ainda não". Acredito que estamos nos afastando da noção de que a maternidade é um chamado natural para toda e qualquer mulher, mas ainda não chegamos lá e ainda há um caminho a percorrer. Mulheres de todo o mundo ainda são pressionadas para serem mães de diferentes formas, uma delas é a tendência horrenda e desoladora de limitar o acesso das mulheres ao aborto (ORNA DONATH, 2018).

Acerca da dimensão estrutural, é pertinente a uma análise mais profunda mencionar que a esfera dos direitos também engloba a dimensão dos deveres e, portanto, das responsabilidades. No que se refere às responsabilidades, a presente tese pretende se debruçar sobre a responsabilização com a educação das crianças pequenas para além da instância familiar, no que é oportuno recuperar o entendimento do conceito da Maternagem. $\mathrm{O}$ Dicionário Houaiss define a Maternagem como uma “[...] técnica empregada na psicoterapia, especialmente das psicoses, que busca estabelecer entre terapeuta e paciente, no simbólico e no real, uma relação semelhante à que existiria entre uma "mãe boa" e seu filho". Ao se contrapor a essa definição, a socióloga estadunidense Nancy Chodorow (1990) considera em suas análises que o fator de influência das construções sociais acerca da maternidade, maternação e maternagem, foram desconsideradas pelas formulações da área da Psicanálise. 
O salto que Chodorow propõe, a partir da ideia da maternação ${ }^{25}$, é o de que a ciência tem dificuldades em explicar como os arranjos sociais contribuem às respostas maternas, já que a Psicanálise atribui à área da Biologia uma série de condições que seriam produtoras de um suposto instinto materno, o que não corresponde à realidade. A autora demonstra que tal afirmação é especulativa, já que a maternação não é fato transcultural imutável (CHODOROW, 1990, p.52).

Outra evidência é que os cuidados e a educação são de cunho interpessoal, difuso e afetivo. Considerando o fator da socialização de gênero, na reprodução de um comportamento esperado da mulher, cria-se o tipo de relacionamento que propicia a elas - e não aos homens maternarem as crianças. Na opinião da autora, o social - e a socialização nos moldes de Mollo Bouvier, perspectiva adotada nessa pesquisa - é a peça chave para ruir com os argumentos relacionados ao instinto nato, o que desconstrói o argumento de que o cuidado e a educação das crianças deve ser responsabilidade apenas das mulheres. A essa releitura - considerando o fator da socialização e da participação de outras pessoas além da mulher na educação das crianças - se coloca a termo a Maternagem. Ademais, a conclusão da interferência do social já era sinalizada no livro de Elisabeth Badinter - Um amor conquistado: o mito do amor materno (1985).

Primeiro, qualquer pessoa que não a mãe (o pai, a ama, etc.) pode "maternar"
uma criança. Segundo, não é só o amor que leva a mulher a cumprir seus
"deveres maternais". A moral, os valores sociais, ou religiosos, podem ser
incitadores tão poderosos quanto o desejo da mãe. É certo que a antiga
divisão sexual do trabalho pesou muito na atribuição das funções da
"maternagem" à mulher, e que, até ontem, esta se afigurava o mais puro
produto da natureza. Será preciso lembrar também que em outras sociedades
- e não das menores - a "boa natureza maternal" tolerava que se matassem
as crianças do sexo feminino ao nascer? (BADINTER, 1985, p.17).

Uma atividade muito disseminada socialmente com que a maioria das mulheres arca são aquelas relativas ao Cuidado, outro conceito utilizado na pesquisa. A esse respeito, as professoras brasileiras Helena Hirata e Nadya Araújo Guimarães (2012) asseveram que.

O care é dificilmente traduzível porque polissêmico. Cuidar do outro, preocupar-se, estar atento às suas necessidades, todos esses diferentes significados, relacionados tanto à atitude quanto à ação, estão presentes na definição do care. Este, ademais, pode ser considerado simultaneamente

\footnotetext{
${ }^{25}$ A ideia da maternação surge a partir do entendimento da socialização dos cuidados maternos, tendo a família como agente central dessa reprodução (Chodorow, 1990).
} 
enquanto prática e enquanto atitude, ou disposição moral (HIRATA; GUIMARÃES, 2012, p.1)

De todo modo as mesmas autoras, ao dissertarem sobre a mercantilização do cuidado, apontam que o desempenho de tarefas ligadas aos cuidados são histórica e massivamente executadas por mulheres.

A profissionalização desse tipo de trabalho e sua remuneração têm a virtude de questionar o care como qualidade "natural" ou "inata" das mulheres. Compreender a dinâmica das ocupações ligadas ao cuidado e à solicitude na esfera mercantil, em sua relação com o trabalho doméstico não remunerado, parece-nos uma precondição para pensar a questão do care do ponto de vista da justiça e da igualdade (MOLLER OKIN, 1989, apud HIRATA; GUIMARÃES, 2012, p.3)

\subsection{TECITURA DA QUESTÃO}

Historicamente os debates sobre a trajetória familiar e profissional das mulheres ganharam destaque no século XIX. A esse respeito, a historiadora estadunidense Joan Wallach Scott (1994) demarca, a partir de trabalho intitulado A Mulher Trabalhadora, que embora as mulheres exercessem funções como a de costureira, empregada doméstica, ama e agricultoras desde o início dos tempos, foi no citado período que se observam os primeiros registros e documentações das preocupações "morais" com o trabalho feminino. A visibilidade da mulher ao exercer um ofício, adquirida seja como fiandeira, seja pelo fato de a mulher ser viúva de um tecelão ou trabalhar como operária despertava sempre as mesmas perguntas: “[...] deve a mulher trabalhar por um salário? Qual o impacto do trabalho no corpo feminino e na sua capacidade de desempenhar as funções maternais e familiares? Que gênero de trabalho é adequado às mulheres?”. (SCOTT, 1994, p.443). O mal-estar se relaciona à “[...] transferência da produção do lar para a fábrica durante o curso da industrialização". O artifício utilizado à época por legisladores homens se baseava em uma "[...] suposta oposição entre lar e trabalho, entre maternidade e salário, entre feminilidade e produtividade". Em outras palavras, Joan Scott assevera que eram as mulheres que eram tidas como anomalias "[...] em um mundo onde trabalho assalariado e responsabilidades familiares tinham se tornado ocupações a tempo inteiro e espacialmente diferenciadas” (SCOTT, 1994, p. 444).

A autora argumenta ainda que as condições históricas de desenvolvimento contribuíram para acentuar as diferenças entre homens e mulheres, pois rompeu com uma continuidade que ocultava diferenças de formação, ofício e estabilidade dos homens em seus 
empregos. Isso revela que nenhum motivo funcional, a não ser o sexo, diferencia homens e mulheres em terem suas ocupações no mercado de trabalho.

A análise de Joan Scott se confirma em outros estudos que discutem os campos de trabalho em que as mulheres se inserem. Pesquisadoras feministas apontam que o trabalho produtivo e o trabalho reprodutivo se articulam, excluindo ou integrando as mulheres à esfera reprodutiva. A esse respeito, a socióloga francesa Anne-Marie Devreux (2011) divulga pesquisa $A$ teoria das relações sociais de sexo: um quadro de análise sobre a dominação masculina, que analisa os mecanismos que os homens utilizam, assim com relatado por Joan Scott, para dividir as funções produtivas e reprodutivas a serem exercidas na esfera do trabalho e na esfera da família. Isso significa que a cidadania exercida pelos homens e pelas mulheres, no que diz respeito aos seus direitos e deveres, vem a ser definida pelo lugar que elas e eles ocupam no âmbito do trabalho e da família (DEVREUX, 2011). É notável que a maternidade, enquanto dado biológico, é constantemente evocada no interior do sistema social, como descrito nas análises de Badinter (2009):

\begin{abstract}
Se frequentemente a influência da afetividade é lembrada, pouco se fala das não menos importantes pressões da família, dos amigos e da sociedade que pesam sobre cada um de nós. Uma mulher (e, em menor grau, um homem) ou um casal sem filhos parecem hoje uma anomalia que provoca questionamento. Que ideia não engravidar e escapar da norma! Eles são sempre obrigados a se explicar, embora não passe pela cabeça de ninguém perguntar a uma mãe por que ela é mãe (e exigir dela razões válidas), fosse a mais infantil e irresponsável das mulheres" (BADINTER, 2009, p.20).
\end{abstract}

Essa é uma das muitas manifestações das relações conservadoras de gênero, que se valem de "arranjos" como esse para se difundir. E o gênero é um constructo útil para compreender a organização dessas relações. A esse respeito, Badinter (1985) - expõe que a suposta ideia de inferioridade da mulher ao homem surge sob forte influência religiosa, reforçada pelo conhecimento teológico cristão, remontando aos tempos da Idade Média. Com o avanço dos tempos, as teorias divinas foram sendo utilizadas a favor das concepções políticas. Nas palavras da citada autora:

A condição do Pai-Marido-Senhor todo-poderoso não pode ser explicada senão pela sua essência. Criatura que mais ativamente participa do divino, seus privilégios devem-se apenas à sua qualidade ontológica. É "natural" que a mais acabada das criaturas comande os demais membros da família, e isso de duas maneiras: em virtude de sua semelhança com a divina, como "Deus comanda suas criaturas", e em virtude de suas responsabilidades políticas, econômicas e jurídicas, como um "Rei comanda seus súditos" (BADINTER, 1985, p.32). 
A estratégia de subjugo da mulher - que consistia no reforço da autoridade paterna passou a ser utilizada com outra roupagem, dessa vez como argumento político para tornar a autoridade soberana irrefutável, já que "[...] a superioridade vem da ordem da geração" (BADINTER, 1985). Tendo em vista que o pensamento cristão atribuía o poder ao sexo masculino por esse ter sido "criado" primeiro, as teorias divinas transpõem essa dominação ao campo político para justificar a soberania do rei perante seus súditos e súditas. Isso remete novamente às análises de Joan Scott, que no texto Gênero: uma categoria útil de análise histórica assevera sobre o caráter das contingências, nos esclarecendo que os significados simbólicos do gênero estão ligados aos interesses políticos de cada época (SCOTT, 1995).

A figura da mãe e as reflexões sobre a maternidade propostas por Badinter (1985) contam com a relativização da importância da posição da mulher ora em relação ao homem, ora em relação à criança. Isso porque além da questão da autoridade do pai sobre a família, os conhecimentos veiculados sobre a infância colocam a mulher em posição de vantagem ou desvantagem em cada tempo histórico, assim como já exposto pelas análises de Burman (2009). Conforme a (não)valorização da infância no decorrer dos tempos, o afeto e a educação dispensados pela mãe conferem a ela alguma estima social, seja na família ou na esfera pública, configurando um quadro de cidadania incompleta, cuja definição se ancora em uma cidadania secundária, por menor prestígio social. Ademais, Badinter (2011) pondera que a maternidade é socialmente idealizada, ao passo que desconsidera uma série de questões e conflitos que a mulher vivencia:

Para aquelas dotadas dessa vocação, a plenitude não para no face a face com o lactente. A criança é obra de uma vida porque é uma criação arrebatadora com a qual nenhuma outra pode rivalizar. Velar por ela desde o nascimento, ajudá-la a se desenvolver, etapa por etapa, para ter a alegria e o orgulho de, um dia, ver um adulto realizado não é uma ambição mesquinha. Ao contrário. Mas a condição do sucesso - jamais garantido - é que a mãe encontre prazer nisso, e o filho também. É ela quem abandona o trabalho sem hesitar para se tornar mãe "exclusiva", ou "intensiva" [...]. As necessidades da criança estão no centro de sua vida, a mãe se compromete profundamente com ela do ponto de vista afetivo e emocional; enfim, dedica-lhe alegremente seu tempo e sua energia (BADINTER,2011, p.149).

Ana Liési Thurler (2009), ao publicar trabalho que apresenta os desafios do reconhecimento institucional à primeira infância, enfatiza a necessidade de análises que considerem as relações entre homens e mulheres, ou seja, os reflexos das relações de gênero. Ao analisar as políticas voltadas às crianças, a pesquisadora atesta que estas possuem " [...] 
medidas que permitem a conciliação família-trabalho [que] estão voltadas especialmente para as mulheres, tornando-se recursos para interferir sobre as carreiras femininas”. Deste modo, o tratamento que a sociedade dispensa às mulheres-mães trabalhadoras, na forma do exercício do poder estatal em prover - ou não - condições para que as mulheres concretizem seus projetos de vida além da maternidade, consiste em um controle social do que se admite como possível, ou desejável, direcionado somente a algumas pessoas. As políticas de atendimento à primeira infância são conhecidas por veicularem que "[...] as creches são serviços oferecidos às mulheres e não às famílias" (THURLER, 2011, p.5). Notadamente, em 2019, quando da realização da pesquisa de campo, algumas participantes do encontro formativo demonstraram preocupações com relação a não-empregabilidade de mães de crianças da creche pesquisada, alegando injustiça para com as mães trabalhadoras, uma vez que não há vagas para todas as crianças. Observa-se que, nesse relato, os direitos das mulheres se sobrepõem aos direitos das crianças, em receberem uma educação institucionalizada e profissionalizada, herança advinda das políticas assistencialistas que visam apenas a superação da pobreza por meio do trabalho, nas classes populares. Novamente, os direitos de ambas as partes são desmerecidos, ao invés de colocados em relação.

Sobre o desmerecimento dos direitos de mulheres e crianças, é importante situá-las enquanto minorias sociais, o que as deixam suscetíveis às vulnerabilidades sociais. O texto Minorias e grupos vulneráveis: a questão terminológica como fator preponderante para uma real inclusão social, de Dirceu Pereira Siqueira e Lorena Roberta Barbosa Castro (2017) reconhecem as minorias sociais como as populações que possuem traços culturais comuns, que permitem que indivíduos reconheçam algum elo entre si. Além da identificação - social, étnica - as minorias sociais comportam outros aspectos em comum. Ainda de acordo com Siqueira e Castro (2017), há o compartilhamento de um status de não dominação do corpo social, o que requer uma proteção especial do Estado. Essa condição também atua de modo subjetivo, uma vez que os indivíduos estabelecem laços de solidariedade entre si, com a finalidade de preservar uma identidade.

Ainda que o termo minoria remeta a algo menor, numericamente falando, na realidade brasileira, as minorias sociais correspondem a grandes grupos populacionais, como as crianças, pessoas negras, indígenas, pessoas idosas, entre outros. Mesmo correspondendo a grandes contingentes numéricos, isso não impede que as minorias sociais brasileiras estejam expostas a fragilidades relacionadas à funcionalidade de seus direitos, em situação de opressão ou supressão dos mesmos (SIQUEIRA; CASTRO, 2017). Tais fragilidades 
constituem as vulnerabilidades sociais que, no caso das mulheres e crianças, se manifestam na forma da insuficiência de vagas nas creches, a exposição à violência doméstica e nas desigualdades no trabalho.

A cientista social Eleonor Faur (2014), autora do livro El cuidado infantil em el siglo XXI: Mujeres malabaristas em una sociedad desigual, nos ensina que os feminismos em muito contribuem para que essas "institucionalizações", como a dificuldade em conceber a creche como corresponsável pela educação das crianças, sejam discutidas sob o viés político. Discutir os cuidados relacionados aos direitos individuais, por exemplo, contribuem para que não se perpetue um sistema regulatório de normas e disposições baseadas em marcos históricos, sociológicos e culturais completamente distintos dos dias atuais (FAUR, 2014, p.142). Isso fica evidente quando citamos as múltiplas trajetórias das mulheres em ocuparem de diferentes modos os espaços públicos, em outros nichos profissionais que não somente àqueles ligados ao cuidar. Rumo à emancipação, foram sendo travadas outras batalhas relacionadas à cidadania da pequena infância, pois isso trouxe para o centro do debate o respeito e a responsabilidade de outros entes para com a educação das crianças.

No Brasil, para as feministas, a luta pela creche significava, no final da década de 1970, uma das bandeiras para a emancipação. As mulheres, lutando pelo atendimento de necessidades básicas em seus bairros, incluíam a creche na agenda de reivindicações dos movimentos que protagonizaram, entendendo-a como um desdobramento de seu direito ao trabalho e à participação política. $\mathrm{O}$ movimento feminista trouxe para a luta a crítica ao papel tradicional da mulher na família e a defesa da responsabilidade de toda a sociedade em relação à educação das novas gerações. "O filho não é só da mãe", diziam os cartazes nas manifestações (FINCO; GOBBI; FARIA, 2015, p.9)

A esse respeito, em recente publicação do ano de 2015, intitulada A participação feminina na luta por creches! a feminista brasileira Maria Amélia de Almeida Teles nos conta que a mobilização política das mulheres levou as creches a galgarem o status de política pública em nosso país a partir das primeiras reinvindicações de mulheres operárias em fábricas já na década de 1930. Com essas demandas, as feministas brasileiras contribuíram em colocar a creche no campo dos direitos das crianças pequenas, mais fortemente a partir da década de 1970.

Com a crescente inserção da mulher no mercado de trabalho, e suas justas e necessárias reivindicações relacionadas à guarda das crianças, as tarefas realizadas pelas mulheres no âmbito do lar ganham visibilidade nos espaços públicos. Mediante essa 
visibilização, observa-se o desenvolvimento de profissões ligadas ao cuidar, dadas às especificidades de públicos que demandam atenção e cuidados, como é o caso das pessoas idosas e das crianças. Ao abordar o cuidado como trabalho, a feminista e filósofa brasileira Helena Hirata assevera que essa dimensão ganhou reconhecimento a partir da mercantilização do trabalho. O texto de Helena Hirata cujo título é $O$ trabalho de cuidado - comparando Brasil, Bélgica e Japão denuncia a maneira invisível com que o trabalho doméstico e os cuidados não remunerados para com a família foram por muito tempo executados por mulheres, quadro pouco modificado quando considerados dados atuais. Contudo, Helena Hirata nos adverte que em muitos países, incluindo o Brasil, essas profissões são pouco valorizadas, "[...] com salários relativamente baixos e pouco reconhecimento social" (HIRATA, 2016, p.54). Considerando a reflexões dos estudos de gênero e do care, a feminista disserta sobre a importância da superação da divisão sexual do trabalho, já que historicamente as atribuições do cuidar foram delegadas às mulheres, assim como as maneiras com que essa centralidade se baseia em atributos como a maternidade e o afeto.

Desse modo, é impossível discutir a perspectiva do cuidado e da Educação para com essa dimensão, sem reconhecer que essa atividade é perpassada por desigualdades de gênero, raça, classe social, no mundo do trabalho. Isso se comprova mediante estudos de perspectiva interseccional, que apontam que as cuidadoras continuam sendo majoritariamente mulheres, da raça negra e das classes populares. Para além desses elementos, surgidos do contexto da globalização e da divisão internacional do trabalho, há também a relação de movimentos migratórios envolvidos nessa dinâmica (HIRATA, 2016). A despeito da interligação de todos esses fatores, ou somente alguns dos citados pela autora, o fato é que as mulheres conjugam as atividades ligadas ao cuidado, seja de modo profissionalizado, seguindo os ofícios de cuidadoras, enfermeiras, trabalhadoras domésticas, professoras e babás, ou não. De maneira pública e privada, a mulher se insere usualmente como trabalhadora e mãe, geralmente em empregos e funções pouco prestigiosas e pouco rentáveis economicamente.

No Brasil, a advogada Regina Stela Corrêa Vieira (2013), ao retomar o histórico jurídico do Direito do Trabalho - em trabalho intitulado Mulher, trabalho e maternidade: análise do sexismo presente no Direito do Trabalho brasileiro como barreira à igualdade de gênero - atesta que as mulheres mães trabalhadoras contaram com tutela especial de seu trabalho, na forma da proteção da maternidade, no ano de 1919, por força de normativas estabelecidas pela Organização Internacional do Trabalho. A primeira norma federal a fazer menção ao trabalho da mulher foi o Decreto 16.300, de 31 de dezembro de 1923, que 
concedeu às trabalhadoras o direito ao repouso de 30 dias antes e 30 dias depois do parto. $\mathrm{O}$ mesmo Decreto também previu a concessão de creches ou salas de amamentação próximas à sede das empresas, para que as mães pudessem amamentar seus filhos em intervalos regulares. Já em 1943, a Consolidação das Leis do Trabalho (CLT) dedicou um capítulo inteiro à essas questões. Intitulado "Da proteção do trabalho da mulher", a proteção à maternidade contava com artigos que previam a licença de seis semanas antes e depois do parto, o auxílio-maternidade, horários de descanso para amamentação. A CLT também instituiu como dever da empresa que possui mais de 30 empregadas a fornecer creches para as crianças (VIEIRA, 2013).

A também advogada argentina Laura Pautassi (2007) disserta no texto Há igualdade na desigualdade? Abrangência e limites das ações afirmativas sobre a reestruturação do Estado em seu funcionamento no tocante à promoção da seguridade social e proteção, observando as muitas desigualdades que afetam especialmente as mulheres quando o foco é a responsabilidade reprodutiva. Isso afeta a contratação em empregos formais e estáveis, razão pela qual os movimentos de mulheres batalharam por condições e equipamentos a serem providos pelas políticas sociais. Pautassi coloca a relação da mulher com o mercado de trabalho como paradoxal, já que, mesmo com o reconhecimento social do trabalho como exercício de cidadania, as mulheres se inserem em um contexto de vulnerabilidade, pois são afetadas pela (não)cobertura de políticas sociais que assegurem a responsabilidade com a sua família. Da tensão entre o reconhecimento formal e a situação de vulnerabilidade, a citada advogada assevera a necessidade da formulação e ação de políticas afirmativas, em que as diferenças são reclamadas para que se possa reequilibrar a balança e se alcançar a igualdade (PAUTASSI, 2007).

Expandindo um pouco mais a discussão da regulamentação trabalhista das mulheres, sobre os locais para a amamentação, Teles acrescenta ainda a crítica de que disposições focalizadas como essa visavam e beneficiavam apenas as crianças bem pequenas (TELES, 2015, p.22). E as que não estavam no período de amamentação? Muito ainda havia de se amadurecer sobre o atendimento às crianças filhas de mães trabalhadoras. Logo, além de políticas públicas, as mulheres também necessitam de equipamentos sociais para exercer sua autonomia, como é o caso das creches e escolas de Educação Infantil.

Ainda sobre as modificações de sociabilidades ligadas ao trabalho das mulheres. No movimento de escrita final da tese, no mês de abril de 2021, ocorreu importante conquista a esse respeito. O Conselho Nacional de Desenvolvimento Científico e Tecnológico (CNPQ) 
anunciou a mudança que permite constar no Currículo Lattes a informação referente à licençamaternidade. Tal reivindicação foi coordenada pelo Movimento Parent in Science, liderado pela pesquisadora brasileira Fernanda Staniscuaski, da UFRGS. Esse espaço representa um reconhecimento quanto aos impactos da maternidade, tanto na produção científica das mulheres cientistas quanto na influência que tais modificações exercem, em outras oportunidades de trabalho, comumente selecionadas pelas informações constantes no Currículo Lattes. Essa modificação passa a vigorar em 15 de abril do mesmo ano ${ }^{26}$.

Mudanças na legislação trabalhista, assim como o reconhecimento legal da infância na Constituição Federal de 1988 e no Estatuto da Criança e do Adolescente de 1990 e a demanda pelas creches, lutas travadas pelas mulheres, constituem-se como pano de fundo dessa tese. Muitas dessas batalhas foram vencidas, ao passo de que galgaram o reconhecimento formal. Contudo, muito ainda há por fazer de modo que esse reconhecimento ganhe efetivamente a vida coletiva, e são nessas lacunas que a tese tem especial interesse em explorar. Um ganho legal extremamente significativo é a promulgação do Estatuto, objeto de estudos do texto Ser criança e adolescente na sociedade brasileira: passado e presente da história dos direitos infanto juvenis, da professora brasileira Isis Longo, mencionado a seguir:

O Estatuto irá sistematizar as principais legislações nacionais e internacionais que contribuíram para a formulação do princípio da garantia universal dos direitos das crianças e dos adolescentes, mas, sobretudo, será o ativismo de milhares de pessoas comprometidas com uma sociedade mais justa e democrática o fator de vanguarda da nova legislação, pois os demais marcos legais da infância, como o Código de Menores de 1927 e o Código de Menores de 1979, foram construídos sob a óptica das elites, sem a participação ativa da sociedade. A Declaração dos Direitos da Criança da ONU em 1959 provocou discussão mundial em torno das demandas da população infantil. A Declaração cobrou dos Estados Nacionais o compromisso com a defesa da proteção especial às crianças, a garantia da universalização dos direitos a todas as crianças, bem como a garantia da educação primária gratuita e obrigatória (LONGO, S/d, p.6)

Reiteramos que, embora seja fato que o Estatuto da Criança e do Adolescente (BRASIL, 1990) estabeleça no quarto artigo de suas disposições preliminares que "[...] é dever da família, da comunidade, da sociedade em geral e do poder público" assegurar a Educação das crianças e adolescentes - sendo, portanto, tarefa de todos os adultos - a figura da mãe é exclusivamente demandada para tal tarefa, recaindo também à mulheres próximas.

\footnotetext{
${ }^{26}$ Fonte: https://gauchazh.clicrbs.com.br/donna/maternidade/noticia/2019/04/maternidade-no-lattespesquisadoras-poderao-indicar-tempo-de-licenca-no-curriculo-cjuvrglx100s201 rowc4q0cgj.html Acesso em 23/04/2021.
} 
Também são reconhecidas legalmente as prescrições da legislação trabalhista brasileira atinentes às trabalhadoras-mães, contudo, não há respaldo quando a mulher exerça algum trabalho intelectual ou que considere seu trabalho no âmbito do lar, quando ela também exerça o trabalho de cuidar e educar. A mesma legislação também estabelece as licençasmaternidade e paternidade, com grandes diferenças de prazos.

Em meados dos anos quarenta, quando os países da América Latina criaram as bases dos Estados de Bem-Estar Social, a mulher continuou sendo tratada como mãe. Tal situação condizia com o formato de um tipo especial de projeto institucional, como os que se desenvolveram na região, especialmente nos países do Cone Sul. Assim, a figura do trabalhador assalariado era masculina. A relação trabalhista "típica" era o emprego regular, de tempo integral, em idade ativa e com raras mudanças na carreira trabalhista. Claramente, as mulheres ficavam em posição de desvantagem, obtendo algumas normas protetoras, mas sem conquistar o princípio da igualdade. Aquilo que juridicamente poderia ser correto, outorgando uma oportunidade de efetiva solidariedade social, teve como resultado um sistema fragmentado e injustamente privilegiado, baseado fundamentalmente nas diferenças verificadas no mercado trabalhista (PAUTASSI, 2007, p.75).

Diante das razões apresentadas, a Educação Infantil se apresenta como importante via que contribui de modo significativo na tarefa de educação das crianças e como condição para as mulheres compatibilizarem-se com os modos de vida e tarefas com os quais se ocupam, salientando para tal, as transformações dos modos de vida da família. As análises da pesquisadora francesa Suzanne Mollo-Bouvier, publicadas em texto de nome Transformação dos modos de socialização das crianças: uma abordagem sociológica (2005), se dedicam à pesquisar como se dá a socialização das crianças mediante as transformações sociais que interferem em seus cotidianos. É importante destacar que a noção de socialização da citada autora, e com a qual concordamos e enfocamos nesse trabalho, se constrói de maneira interacionista "[...] pelo vínculo entre conhecimento de si e conhecimento do outro, construção de si e construção do outro" (MOLLO-BOUVIER, 2005, p. 392), superando a noção clássica da perspectiva assimilacionista e metódica difundida por Émile Durkheim, cujas formulações apontam no sentido de que "a educação é a ação exercida, pelas gerações adultas, sobre as gerações que não se encontrem ainda preparadas para a vida social" (DURKHEIM apud FAUCONNET, p.41, 2007).

Durkheim é reconhecido como um dos precursores da Sociologia, e importante intelectual que iluminou a Educação como fundamental ao desenvolvimento das crianças, na necessidade da aquisição de conhecimentos e práticas relacionadas às necessidades sociais. A crítica de Paul Fauconnet (2007) ao pensamento durkheimianno, que versava que o principal 
fim da Educação seria o de imersão na sociedade, principalmente na esfera do trabalho, nos instiga a pensar para além desse prisma, tanto no que diz respeito às manifestações individuais quanto às opiniões coletivas, nas quais dialogam as crenças, as práticas, as políticas e os conhecimentos, adquiridos na escola e fora dela, por todas as pessoas envolvidas na ação de educar.

As necessidades sociais vêm sendo visibilizadas nas suas variadas manifestações - de direitos garantidos à construção de novos direitos- nos dizendo que estas são passíveis de mudanças. Diante da possibilidade concreta de transformação social, é imperativo discutir as realidades sociais inscritas nas esferas dos direitos, como a exposição às vulnerabilidades da pobreza, da violência, dos serviços insuficientes de creches, das políticas de emprego e educação que afetam, dentre outras minorias sociais, as mulheres e as crianças.

Considerando os ajustes a situações ao longo dos tempos, para além do trabalho das mulheres, da urbanização e outros já mencionados nesse trabalho, Mollo-Bouvier (2005) acrescenta ao debate sobre a Educação quatro fatores de transformação da socialização infantil, como o interesse na escolarização precoce, a segmentação social das idades e as flutuações relacionadas ao período da infância, bem como as transformações em termos das concepções de infância, além da promoção da socialização em instâncias fora da família, multiplicando-se assim os modos de atendimento e também as instituições voltadas às crianças.

Desse ponto, é pertinente uma reflexão sobre a disponibilização de turnos dos serviços das creches e escolas de Educação Infantil. No Brasil há creches e escolas que atendem em diferentes regimes de carga horária, seja recebendo as crianças em meio período, período integral e também em período noturno, implantado recentemente no município de Curitiba, no estado do Paraná. Sobre essa iniciativa, o artigo das professoras brasileiras Marilúcia Antônia de Resende e Ilze Maria Coelho Machado (2012) - divulgado em artigo intitulado Educação infantil no período noturno: a prática pedagógica em contexto de vulnerabilidade social - é contundente em apontar, ao lado de superações e desafios, os benefícios da oferta de creches em carga horária estendida. As citadas professoras pontuam que a Educação deve se comprometer a pensar

as relações inerentes ao processo educativo: a relação entre adultos e crianças, as condições objetivas de trabalho e o posicionamento das profissionais, a relação destas com os saberes, o nível de envolvimento com as famílias, bem como a proposta educativa que orienta a prática pedagógica (RESENDE; MACHADO, 2012, p.12). 
Resende e Machado (2012) alertam ainda que, mesmo havendo uma forte demanda da população na oferta noturna de creches e da Educação Infantil, tanto as decisões de implantação desse regime quanto as propostas pedagógicas precisam ser bem delineadas, "“...] pois a extensão não pode se constituir enquanto um espaço com o único objetivo de cuidado das crianças enquanto seus familiares ou responsáveis trabalham" (RESENDE; MACHADO, 2012, p.9). Há de se priorizar a articulação do cuidar e do educar e superar a visão do assistencialismo, tendo em vista de que a implantação do período noturno da Educação Infantil em Curitiba (PR) surgiu relacionada às preocupações do Conselho Tutelar do citado município para com as crianças filhas de trabalhadoras e trabalhadores em situação de vulnerabilidade social, especialmente aquelas/es que exercem atividades ligadas à coleta de materiais recicláveis. Sobre a importância da ação dos Conselhos Tutelares, novamente a professora brasileira Isis Longo traz interessante contribuição sobre o que representa a intervenção do poder público em termos de garantia e proteção de direitos:

Pela Doutrina de Proteção Integral, a criança e o adolescente, por suas características peculiares de pessoas em desenvolvimento, têm o direito à proteção integral da família, sociedade e Estado. De acordo com tal doutrina, o segmento infanto-juvenil tem garantias jurídicas que asseguram os seus direitos e adotam as medidas de proteção e as medidas socioeducativas, como substituição do caráter repressivo e punitivo da Doutrina da Situação Irregular (LONGO, S/D, p.11-12).

Da demanda específica de proteção às crianças, que vem a ser um ganho social fundamental, e também em virtude do crescimento econômico, ocorreu a ampliação do público de famílias atendidas nas creches de período noturno na cidade de Curitiba, como as crianças filhas de "[...] trabalhadores de shopping, mães estudantes, as mulheres que trabalham nos turnos das fábricas, no comércio diversificado em que o atendimento se estende até determinado horário noturno e os coletores de material reciclável" (RESENDE; MACHADO, 2012, p.9).

Ao nos apresentar essa possibilidade, as autoras colocam que os municípios têm autonomia nas decisões dos horários de atendimento, em uma flexibilização possível. Diante da consideração de circunstâncias como as citadas e também da reinvindicação daquela população, podemos concluir que são necessárias reflexões sobre a organização da instituição creche e sobre seus fins sociais, sem perder de vista, obviamente, os pilares e propósitos da 
Educação Infantil e a prioridade do sujeito criança, o que se confirma pela reflexão de Resende e Machado (2012):

[...] é inegável que a discussão perpassa uma questão econômica, social e política. A polêmica transcende o cenário educacional, uma vez que estão em jogo os interesses das famílias, o bem estar das crianças e as finalidades da educação infantil, enquanto instância complementar à família e à comunidade (RESENDE; MACHADO, 2012, p.9).

É notável a atuação de entidades e associações comprometidas com o social, que colaboram com propostas de atendimento e militância na seara da Educação. Nesse nicho se encontram mobilizadas diversas/os pesquisadoras/es, integrantes ou não de movimentos sociais, profissionais e pessoas atuantes de distintas áreas que conformam organizações de diversas naturezas, que se organizam tanto a nível municipal quanto estadual ou federal, com a proposta de contribuir de maneira democrática para a qualidade dos debates.

Em observância à participação da sociedade nos setores de interesse social, a atuação de Conselhos relacionados aos temas dos direitos e da Educação, como os Conselhos Tutelares, dos Direitos das Mulheres e da Educação têm papel complementar, mas não menos importante, de assegurar dentre outros, o direito à creche. Como apontado da dissertação de Mestrado de Claudinei Santos Lima (2014), os Conselhos Tutelares brasileiros surgem a partir das disposições dos artigos 131 e $132^{27}$ do Estatuto da Criança e do Adolescente (BRASIL, 1990), “[...] cabendo ao mesmo aplicar medidas protetivas previstas no Estatuto da Criança e do Adolescente, principalmente do art. 101 para crianças e adolescentes e no art.129 para pais e responsáveis" (LIMA, 2014, p.15) ${ }^{28}$, constituindo importante instância de zelo para com os direitos de crianças e também adolescentes. Luis Antonio Miguel Ferreira (2010) ressalta que o projeto do ECA foi tratado pelo senador Ronan Tito como uma "pequena Constituição", posto que abrangeu uma parcela significativa da população brasileira e tratou de questões importantes “[...] que vão desde a assistência materno-infantil até o acesso à justiça, passando pela educação, saúde, convivência familiar, lazer, cultura, profissionalização e proteção ao trabalho" (FERREIRA, 2010, p. 49).

\footnotetext{
${ }^{27}$ Art. 131. O Conselho Tutelar é órgão permanente e autônomo, não jurisdicional, encarregado pela sociedade de zelar pelo cumprimento dos direitos da criança e do adolescente.

Art. 132. Em cada Município haverá, no mínimo, um Conselho Tutelar composto de cinco membros, eleitos pelos cidadãos locais para mandato de três anos, permitida uma reeleição (BRASIL, 1990, p.45).

${ }^{28} \mathrm{O}$ artigo 101 do ECA dispõe das medidas específicas de proteção à criança (BRASIL, 1990, p. 33) e o artigo 129 prescreve as medidas pertinentes aos pais ou responsável (BRASIL, 1990, p.43).
} 
As crianças e adolescentes ganham o reconhecimento como cidadãs, superando a situação de menor, característica das legislações anteriores. Sobre as políticas de atendimento à esses direitos, o Estatuto da criança e do adolescente - ECA regulamenta que existam linhas de atendimento articulada em todas as esferas governamentais (União, Estados e Municípios) e não-governamentais que exerçam políticas de proteção, amparo e atendimento, como as políticas sociais básicas, programas de assistência social, serviços de prevenção e atendimento médico e proteção jurídico-social (BRASIL, 1990). Sobre o atendimento, o ECA estabelece a “[...] criação de conselhos municipais, estaduais e nacionais dos direitos da criança e do adolescente, órgãos deliberativos e controladores das ações em todos os níveis, assegurada a participação popular paritária [...]” (BRASIL, 1990, art.88, inc. II). Das instituições responsáveis pela fiscalização das entidades citadas, localizam-se o poder judiciário, o Ministério Público e os Conselhos Tutelares (BRASIL, 1990, art.95). Evocando novamente as análises de Isis Longo:

$\mathrm{Na}$ interpretação de especialistas do direito, como Wilson Liberatti (1997), o Conselho Tutelar é o que há de mais democrático na justiça brasileira, pois os conselheiros têm mandato eletivo pelo povo e têm autonomia frente aos poderes executivo e judiciário, que permite que o órgão 'conselho' seja a instância de melhor comunicação entre comunidade e poder público (LONGO, S/d, p.13).

Podemos acrescentar as importantes ações do Conselho Nacional dos Direitos da Mulher (CNDM) atualmente vinculado à Secretaria de Política para as Mulheres. Criado em 1985, o CNDM vem trabalhando em políticas públicas que visam ampliar a participação social das mulheres, bem como combater a discriminação contra elas e articular o diálogo de instituições públicas com a sociedade civil ${ }^{29}$. Já em 1996, o Conselho Nacional da Educação (CNE), criado em substituição ao Conselho Federal de Educação, tem a incumbência de regulamentar diretrizes em suporte ao Ministério da Educação, diagnosticar problemas e promover discussões que auxiliem nas melhorias da Educação como um todo. Como função mais importante o CNE realiza o acompanhamento da elaboração e execução do Plano Nacional de Educação (PNE) ${ }^{30}$.

Conforme as atribuições dessas entidades, podemos concluir que tais instâncias atuam na perspectiva do controle social das políticas públicas sociais, que atingem também a seara da Educação, como na mudança dos turnos das creches que existe no município de Curitiba

\footnotetext{
${ }^{29}$ Fonte: http://www.spm.gov.br Acesso em 04/01/2019.

${ }^{30}$ Fonte: http://www.ebc.com.br Acesso em 04/01/2019.
} 
(PR). A esse respeito, associamos novamente os trabalhos de Mollo Bouvier (2005) que dissertam também sobre a mudança de expectativas com relação às creches e seus impactos sobre as infâncias. Se é incerta a delimitação da infância, não quer dizer que não existam normas ou prescrições que atuem demarcando a socialização da infância. Mollo Bouvier aponta como exemplo o marco da idade de 6 anos, admitida pela escola tradicional como o início da escolarização obrigatória. Outro ponto que há de se ter clareza é sobre a conexão da Educação com a sociedade em atualizar-se no que se refere às relações de trabalho das mães e famílias.

Além disso, as iniciativas que conhecemos por meio da atuação dos Conselhos citados aqui é a consolidação de possibilidade de mudança que a política pública de atenção aos direitos das crianças e das mulheres pode promover. É nesse sentido que Eleonor Faur (2014) propõe reconstruções em conceber os cuidados e as questões relacionadas aos direitos analisando a conjuntura social contemporânea, como já mencionado nesse trabalho. A professora brasileira Sonia Kramer (1989, p.13) defende que a escola, ao "[...] desempenhar seu papel de ensinar criticamente, fornecendo instrumentos básicos para o exercício da cidadania”, é instância potente em contribuir para uma sociedade mais democrática.

Ao representar campo de acesso e permanência de modo democrático, isso se traduz em uma Educação mais igualitária para as crianças. Pretendemos aprofundar mais esse debate adotando a via das relações de maternagem exercidas na escola, que é um dos elementos que se pretende investigar nesse trabalho. As relações de maternagem, como exposto em pesquisa intitulada Discursos que (com)formam corpos grávidos: da medicina à educação física das professoras brasileiras Simone Schwengber e Dagmar Meyer (2011), dizem respeito a criar e educar, e não somente à gestação e parto, ou o que pode ser notado meramente como aspecto biológico. Nessa perspectiva de análise, Dagmar Meyer (2005) - no texto Uma politização contemporânea da maternidade: construindo um argumento - recupera as maneiras com que o aleitamento materno foi abordado em controversas teorias como elemento de associação da mulher à fatores como a urbanização, o fortalecimento do capitalismo e da formação dos Estados Nacionais. Esse fenômeno, denominado "politização do feminino e da maternidade", coloca a mulher como a figura central das "políticas de gestão da vida" nas sociedades (MEYER, 2005, p.81-82), assim como as preocupações relacionadas aos cuidados na gestação e investimentos educativo-assistenciais voltados às mulheres-mães, o que provoca um distanciamento da maternagem como incumbência social, ou seja, de agência de outras 
pessoas além da mãe. Como disposto na primeira seção do terceiro capítulo da Constituição Federal, que versa sobre a Educação

A educação, direito de todos e dever do Estado e da família, será promovida
e incentivada com a colaboração da sociedade, visando ao pleno
desenvolvimento da pessoa, seu preparo para o exercício da cidadania e sua
qualificação para o trabalho (BRASIL, 1988, Art. 205).

Há, portanto, uma lacuna entre o que prescreve a legislação, que legitima uma reconstrução da responsabilidade, e as práticas sociais, que tendem a corresponder, não à sociabilidade proposta por lei, mas ao olhar que tradicionalmente incumbe somente a mulher nos cuidados com a gestação e com a educação das crianças.

A centralidade desses cuidados, materializados com as preocupações com o aleitamento materno também foram foco de discussão do livro O conflito: a Mulher e a Mãe, da feminista francesa Elisabeth Badinter (2009), que identifica nessas preocupações com a amamentação uma estratégia política baseada no naturalismo biológico:

Ele se apoia em dois princípios mais ou menos claramente formulados. $\mathrm{O}$ primeiro diz que a boa mãe põe "naturalmente" as necessidades do filho acima de tudo. O segundo, que as necessidades do filho são estabelecidas pela "natureza", e que são progressivamente cada vez mais conhecidas (BADINTER, 2009, p.88).

Entretanto, Badinter (2009) contrapõe que muitas "certezas" médicas são infundadas, bem como "simplesmente esqueceram de levar em conta as características sociais, econômicas e culturais da mãe, bem como sua situação familiar" como fatores que interferem na amamentação, o que não justifica a ideologia maternalista associar a boa maternidade ao aleitamento, classificando as mães como boas ou más, desconsiderando sua vontade ou dificuldade em amamentar, e com isso, a ambivalência das mães. Ao lado disso, a despeito de as mulheres incorporarem - ou não - essa discursividade, surgem questões relacionadas às sociabilidades contemporâneas, como o compartilhamento das responsabilidades com a Educação das crianças com outras pessoas além da mãe. Vincular essa discussão à Educação é também contribuir para que as crianças se apropriem de um cenário mais justo socialmente, a partir de reconstruções de modelos de comportamento alicerçados em relações em que todas as pessoas compartilhem das responsabilidades de educá-las, como já previsto em legislações brasileiras, a exemplo do Constituição Federal e do Estatuto da Criança e do Adolescente. 
Logo, a pesquisa objetiva conhecer como a creche materna as crianças. Ao lado disso, saber se a creche se reconhece como espaço de direitos das crianças e mulheres. Para que o objetivo maior da proposta desse projeto se concretize, propomos realizar estudo bibliográfíco em plataformas online sobre os elementos básicos do tema da pesquisa, a saber: Maternidade, maternagem, cuidado, gênero e Educação Infantil, a fim de discutir como os elementos citados são evocados acadêmica e politicamente. Isso implica também em conhecer melhor as discussões políticas que fomentaram os movimentos de mulheres e suas reivindicações sobre os seus direitos e os direitos à Educação das crianças por meio das creches e escolas de Educação Infantil. Logo, pretendemos citar também os marcos e textos legais da Constituição Federal de 1988 e o Estatuto da Criança e do Adolescente de 1990 a respeito das disposições gerais da Educação e suas responsabilizações, buscando referências às categorias pesquisadas nesses documentos orientadores.

Todas as nuances mencionadas, em que se colocam as responsabilizações e fins sociais da Educação, pela ótica dos direitos das crianças e das mulheres, se materializaram em discussões com a equipe pedagógica da creche, em pesquisa-formação, na forma de encontros formativos, a fim de conhecer como os temas pesquisados são pensados, e como se fazem presentes no grupo pesquisado ${ }^{31}$. Os dados obtidos, no que denominamos encontros formativos foram comparados às orientações dos documentos e o que indicam as fontes teóricas a respeito das construções sobre as infâncias, o gênero e a esfera dos direitos de crianças e mulheres. A análise final, baseada nesses elementos, tem a proposta de contribuir em um olhar crítico e sensível para as questões das infâncias que, ao abordar as interseccionalidades das categorias raça, classe e geração com o gênero, podem consolidar democraticamente os direitos das crianças e das mulheres.

Explicitadas as bases em que a tese tece suas reflexões, o próximo item realizará discussão mais focalizada no nível de ensino da Educação Infantil, considerando os atravessamentos envolvidos na educação das crianças pequenas.

\footnotetext{
${ }^{31}$ A princípio, a metodologia da etapa do campo de pesquisa foi desenhada enquanto grupo focal. Mediante considerações da banca de qualificação, consideramos mais significativa a proposta da pesquisa-formação, na qual as contribuições das participantes pudessem ser debatidas, refletidas e ressignificadas, por meio de materiais de estudos ofertados em cada encontro, constituindo possibilidade de formação profissional. A pesquisa-formação e os encontros formativos estão detalhados no item que apresenta a Metodologia.
} 


\subsection{O CUIDAR E O EDUCAR NA EDUCAÇÃO INFANTIL - O FAZER PEDAGÓGICO COMO TECITURA DA CIDADANIA}

Recuperando a intenção principal da tese, que visa conhecer a maternagem na Educação Infantil, recorremos ao escopo final de textos da pesquisa bibliográfica e de obras de referência para acessarmos os debates e as questões de pesquisa. A partir dessas leituras, uma ampla conjuntura que analisa o direito à Educação se materializa nas práticas cotidianas, desde as maneiras de se (re)conhecer, ser e estar como crianças e professoras nas creches e escolas de Educação Infantil, passando pela mediação de brincadeiras, atividades esportivas e dispositivos ligados ao cuidado que norteiam a formação docente e a gestão escolar. Ao lado disso, também se colocam as especificidades das atividades das mulheres, historicamente conhecidas como acumuladoras de trabalhos produtivo e reprodutivo, bem como os embates que envolvem a coparentalidade, múltiplas jornadas de trabalho, a dedicação à carreira (e a escolha dessa) e o envolvimento na esfera dos cuidados. Dessa maneira, se colocam como espaços de discussão a escola e a vida pública, gerenciadas, cada uma a sua maneira, por ditames "pedagógicos" e de ordem pública, seja pela via jurídica, nas formas de leis e regulamentações, ou pelas relações sociais.

O fato é que, na escola e em outras instituições sociais, mais amplas e informais, se encontram as relações de gênero, que operam no que a professora Daniela Auad denominou de "aprendizado da separação". Meninas e meninos apreendem o que é socialmente esperado em termos de conduta por várias vias de socialização, como valores compartilhados pela família e comunidade na qual elas/es convivem. Contudo, é na escola que "[...] se legitima e transmite modelos masculinos e femininos tradicionais". Mas o movimento inverso é possível, pois também ocorrem na escola "[...] acontecimentos motivadores de novos e alternativos arranjos e exercícios acerca do masculino e do feminino" (AUAD, 2004, p.25). Nesse sentido, a professora brasileira Elisângela Araújo (2013, p. 1), em artigo intitulado $O$ escondido e o desenhado nos bastidores da educação infantil, que discute sobre as intervenções pedagógicas, quando essas reportam às relações de gênero, étnico-raciais e de sexualidade, corrobora as análises de Auad, ao colocar que as crianças são educadas, desde cedo, para a perpetuação das desigualdades, mas que ainda assim a instituição de Educação Infantil pode atuar colonizando e descolonizando crianças. Tal diagnóstico pode ser pensado numa inserção na perspectiva da justiça social, pois se é possível que a Educação Infantil viabilize a reconstrução de práticas e conhecimentos que debatam racionalmente o racismo e 
as discriminações de gênero, o enfrentamento de tais desigualdades se reconfiguram constituindo outros saberes, pela via da escolarização.

\begin{abstract}
Nessa perspectiva, é preciso pensar uma educação infantil que apresente no seu currículo preocupações com as questões étnicas, as relações de gênero e sexualidade traduzindo-se nas possibilidades de educação que busca $o$ desenvolvimento integral da criança e, como tal, borda caminhos que possibilitam uma sociedade mais igualitária, humana, menos preconceituosa e não homofóbica. Este é um processo árduo, pois envolve valores socialmente construídos e formatados, envolve rejeição, recusas e sensibilidades, mas que pode fomentar práticas educativas transgressoras nas questões que remetem ao respeito, às diversidades" (ARAÚJO,2013, p.5).
\end{abstract}

Se por um lado, se elucida a potencialidade da modificação das relações interpessoais no ambiente escolar, favorecida pela desconstrução das relações de gênero conservadoras, por outro, o que poderia ser atingido, no nível macro das políticas públicas, se tais relações fossem discutidas ante os problemas sociais que afetam as mulheres? Essa pergunta é a base de muitas elaborações feministas, como as de Faur (2014), já que as mulheres atuam como verdadeiras malabaristas conciliando a vida profissional, a maternidade e os cuidados com a família, o que acarreta adoecimento, desigualdade salarial e desigualdades nos mais variados aspectos das condições de vida.

Figura 1. 1: Mafalda

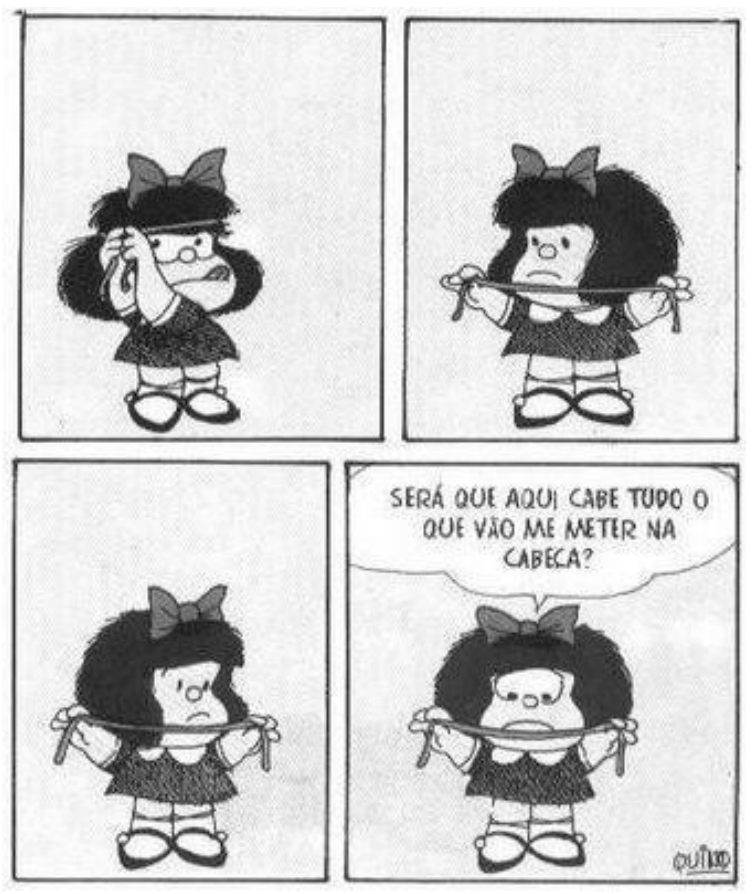

Fonte:http://inovareduca.blogspot.com/2012/06/avaliacao-da- aprendizagemaprender.html\#.YGMnVdJKjIU 
Faur (2014, p.118) afirma que a relação entre trabalho e família se constitui em um objeto social que abarca "constelações" peculiares, dadas as distintas conformações que esses âmbitos podem adquirir perante as interações, superposições e combinações. Isso revela a dicotomia histórica da hierarquização das esferas pública e privada, e olhar o contexto trabalho-família nos permite acessar não só o sistema econômico e social, mas também a gestão dos recursos humanos e os modos com que as instituições, e quem recorre a elas concorre para a renúncia ou escolha das atividades produtivas e privadas (FAUR, 2014).

A esse respeito, Vieira (2013) ao abordar o sexismo no Direito do Trabalho Brasileiro, nos relata que é crescente o percentual de mulheres que trabalham ou que estão à procura de trabalho, mas que mesmo assim não se desvinculam de suas funções de cuidados familiares na chamada dupla jornada, “[...] uma vez que [ela] determina a restrição do número de mulheres que conseguem ter uma vida produtiva linear, sem interrupções, seja em termos qualitativos, pois determina a segregação das mulheres em trabalhos precários e por tempo parcial" (VIEIRA, 2013, p.2).

Logo, essa tese compartilha do entendimento que as creches e escolas de Educação Infantil devem (ou deveriam) se alinhar com as práticas sociais cotidianas, atendendo as demandas de quem utiliza seus serviços, por parte das mulheres, e por parte das crianças, garantir sua Educação e cuidados, direitos seus. Mesmo porque o trabalho Socialização do cuidado e desigualdades sociais da socióloga brasileira Bila Sorj (2014), acessado em busca bibliográfica, indica que:

A via da socialização dos cuidados através de instituições públicas tem mostrado efeitos muito positivos sobre as desigualdades de classe e de gênero no Brasil. Apesar de o acesso à educação infantil, notadamente às creches, ser muito restritivo, as mães cujos filhos frequentam creches e préescolas não apenas apresentam maior taxa de ocupação no mercado de trabalho como trabalham em atividades mais formalizadas, ampliam o número de horas trabalhadas e auferem maior renda do trabalho. Essas vantagens são ainda mais acentuadas nos estratos de renda mais pobres (Sorj e Fontes, 2007). Hoje, a demanda por creche constitui uma das principais reivindicações das mulheres dirigidas ao poder público (Data Popular/sos Corpo, 2012) (SORJ, 2014, p.126-127)

No texto A participação feminina na luta por creches! Teles (2015) analisa que a creche e a preocupação com o bem-estar das crianças começam a ganhar status de política pública, pois as crianças começam a ser vistas como cidadãs em desenvolvimento. As feministas, além de exigir a creche como espaço de necessidade diante da dupla jornada de 
trabalho, atentaram, ao longo do tempo, sobre a importância de conceber "[...] a creche como espaço de socialização de crianças e isso implica em adquirir qualidade profissional e condições adequadas para todos os atores envolvidos: crianças, mães, pais e profissionais" (TELES, 2015, p.25). Ao entoarem que as creches não devem funcionar como depósito de crianças e nem com fins à caridade, as mulheres cobram do Estado a garantia de "[...] políticas públicas que propiciem espaços sociais e pedagógicos para que as crianças pequenas sejam acolhidas e socializadas". É, dessa maneira, que as creches ganham o caráter político no Brasil, em defesa de uma liberdade (!) ao lado de lutas como a oposição à ditadura, a anistia a pessoas presas e a luta por uma constituinte livre e soberana (TELES, 2015).

Ainda de acordo com a mesma autora, a princípio, alguns setores políticos, não acreditaram na força política da creche que, segundo eles, seria um problema menor. Contudo, com essa reivindicação, as feministas denunciaram a discriminação histórica que as mulheres sempre sofreram, enfrentando a divisão sexual do trabalho, discutindo o amor materno e questionando os alicerces dessa construção, apresentando outras bases de pensamento, discutindo que:

\begin{abstract}
A maternidade é uma função social, e interessa a toda sociedade que deve estar preparada política e afetivamente para receber, cuidar, educar e socializar as crianças pequenas. A creche não é um problema individual, é uma questão social. Neste debate, o feminismo concebe a creche como um direito das crianças pequenas à educação, sem excluir dos direitos das mães trabalhadoras à sua realização social e profissional, condições fundamentais para sua emancipação (TELES, 2015, p.25).
\end{abstract}

Ainda sobre a questão dos cuidados, dessa vez, no âmbito da Educação Infantil, a tese de Doutorado da professora brasileira Erica Dumont Pena (2015), cujo título é Cuidar: relações sociais, práticas e sentidos no contexto da Educação Infantil, nos diz que

[...] a prevalência da concepção que considera, como processo indissociável, o cuidado e a educação das crianças pequenas em Instituições de Educação Infantil, percebendo-os como dimensões intrinsecamente associadas, não podendo ser segmentadas nas relações cotidianas com as crianças. Outra característica fundamental que sustenta as concepções de Educação Infantil que se fazem vigentes na legislação e demais instrumentos normativos refere-se à ideia de complementaridade e compartilhamento, entre família e Instituições de Educação Infantil, dos cuidados e da educação das crianças (PENA, 2015, p.25-26).

Tal assertiva se afina com o argumento dessa tese sobre a corresponsabilidade com a Educação. Ainda segundo Pena (2015), uma marca fundamental da discussão sobre o cuidado 
e a educação das crianças pequenas são, de acordo com a definição ampla da socióloga Helena Hirata, as relações sociais cujo objeto é o outro (PENA, 2015), comumente desempenhadas por mulheres em condições de subalternidade com o intuito de satisfazer o bem-estar desse outro. Destaca-se a interface entre a divisão sexual do trabalho - produtora da exploração das mulheres - e a "necessidade da compreensão do cuidado do ponto de vista das práticas, dos afetos, das atitudes e da ética das cuidadoras", de modo a nos fazer refletir sobre a desvalorização das mulheres que se dedicam a profissões ligadas ao cuidado e também asseveram que "o cuidado é uma atividade universal e que, uma vez que todos precisam de cuidado, todos, e não algumas, deveriam cuidar" (PENA, 2015, p.16), crítica essa interessante ao bojo da tese.

Um aspecto importante da relação social de cuidado, e que tem sido pouco problematizado nos estudos contemporâneos, como apurado no trabalho de Pena $(2015$, p.17) é a sua correspondência com a estrutura da relação entre mãe e filha/o, ainda que em muito debatido por feministas como Elisabeth Badinter e Orna Donath, já citadas anteriormente. Essa estrutura, além de ser uma constante referência para os argumentos naturalistas sobre serem as mulheres cuidadoras natas, também determina importantes processos sociais nos quais se constituem relações, saberes e habilidades de cuidado. Também é questão recorrente, e comprovada por dados expostos nesse trabalho, que não mais somente a mãe se incumbe da educação das crianças.

[...] a externalização do cuidado e da educação das crianças, iniciada hoje na mais tenra infância. A externalização implica que, em muitos casos, não são mais as mães as que mais constantemente vivenciam as relações de cuidado e educação com as crianças, na esfera doméstica, de modo tácito e não pago. Ao mesmo tempo, há a emergência de agentes responsáveis pelas relações de cuidado e educação das crianças, em instituições públicas, em situações profissionais e assalariadas (PENA, 2015, p.17).

No entanto, a tese de Pena (2015) conseguiu apreender que a influência da relação mãe e filha(o) era importante na constituição dos saberes de cuidado das mulheres que exercem o cuidado como trabalho. Nota-se que a aprendizagem de cuidado ocorria ainda quando crianças, nas brincadeiras de "casinha" e/ou diante da necessidade de cuidar da/o/as/os, irmã/o/ãs/os mais novos. Assim sendo

Diante da externalização do cuidado com as crianças e da constatação da constituição dos saberes de cuidado na esfera familiar tendo como base, principalmente, a estrutura de cuidado entre mães e filha(o), também nos perguntamos sobre as agentes da Educação Infantil, as quais também têm 
(ou devem ter) o cuidado incorporado - e essa parece ser mesmo a melhor palavra. Para atuar em creches e pré-escolas exige-se ser a(o) professora(professor), formado em curso superior, admitindo-se, para a Educação Infantil e para os anos iniciais do Ensino Fundamental, a formação em nível médio, na modalidade Normal (art. 62 da LDB - Lei n. 9.394/96), cuja função define-se por "educar e cuidar" (BRASIL, 1994) (PENA, 2015, p.18).

Ainda segundo Pena (2015), há também a histórica vinculação dos serviços dos cuidados aos grupos subalternizados da sociedade brasileira. A creche se estrutura na compreensão da identificação dos sujeitos que pretendia atender, inserida em uma dicotomia de serviços, que ora se caracterizavam pela função de guarda e de cuidados das crianças, ora como prestadora de serviços educacionais. Dessa polarização surge, conforme os trabalhos de Moysés Khulmann Junior (1998) no século XIX, a conhecida divisão entre creche e préescola, em que a creche se vincula historicamente à assistência social, orientada para a guarda de crianças pobres e de famílias consideradas inaptas a educar ${ }^{32}$. Complementando a respeito da construção dessa moralidade sobre o cuidado, o texto Ser Mulher, Mãe e Pobre, da antropóloga americana Cláudia Fonseca (2000) avalia o olhar da sociedade sobre a figura da mulher quando o tema em tela era a guarda das crianças no início do século XX:

Há uma tendência, nas análises tradicionais, de espelhar o sistema vitoriano de classificação. Dividindo as mulheres em santas ou demônios, pacatas donas de casa ou prostitutas, os pesquisadores simplesmente não enxergavam dinâmicas sociais que driblam esses dois polos. Da mesma forma, cientistas sociais se agarraram durante décadas à crença na normalidade -estatística, natural, moral- da família conjugal. Hoje, vemos que essa crença, além de ter reforçado a estigmatização das famílias pobres vistas inevitavelmente como desorganizadas por não corresponderem ao modelo "normal" - impediu gerações de pesquisadores de atentar para a diversidade de dinâmicas familiares no Brasil (FONSECA, 2000, p. 513).

Nessa direção, Cláudia Fonseca (2000) nos elucida como a educação das crianças se torna peça-chave para as mudanças das sociabilidades, difundidas na pirâmide social, do alto para baixo, contando com as premissas científicas da época. Também, o estudo $O$ movimento

\footnotetext{
${ }^{32}$ Conceber uma família inapta era, de acordo com os discursos higienistas do século XIX, perceber traços que se chocavam com a moralidade da época. Nesse sentido, as famílias pobres, econômica ou moralmente, eram alvo de políticas sociais que procuravam ajustá-las às competências da sociedade dominante, com apoio científico advindos dos conhecimentos das áreas da Medicina e do Direito. Tais discursos moralizadores são melhor aprofundados em Trabalho de Conclusão de Curso intitulado Relações de Gênero e Educação Infantil: o antigo e não esgotado debate da Formação Docente nos cursos de Pedagogia (RAMOS, 2013).
} 
de mulheres e abertura política no Brasil: o caso das creches, da psicóloga brasileira Fúlvia Rosemberg (1984) analisa que

O desordenado processo de urbanização, com a consequente precarização
das condições materiais de vida de expressivo número de famílias, significou
a formação de uma camada empobrecida e distante de redes de apoio
familiares capazes de oferecer ajuda no cuidado e educação das crianças. O
recurso a creches públicas e, especialmente, comunitárias e filantrópicas,
com parcos recursos, pessoal não qualificado e pouco estável, despertou
preocupações relativas aos impactos no desenvolvimento saudável das
crianças. O modelo de substituto materno sofreu também a crítica feminista,
na medida em que, ao considerar a necessidade de serviço de cuidado
substituto à mãe, reforçava a ideologia de que a mulher/mãe era a única
capaz de cuidar das(os) filhas(os), contribuindo para tornar naturais a divisão
sexual do trabalho e suas consequências de desigualdade entre homens e
mulheres nas diferentes esferas da vida (ROSEMBERG, 1984, apud PENA,
2015, p.26).

Como forma de resistência às citadas moralidades, os movimentos de luta pelas creches, pleiteadas pelas mulheres e movimentos feministas se constituíram reivindicando o reconhecimento das creches como serviço público, bem como os meios necessários para a manutenção dessas e a atenção com as concepções de cuidado e educação destinadas às crianças. As mulheres que protagonizaram esses movimentos eram de bairros de periferia e de vilas adjacentes aos grandes centros urbanos (PENA, 2015), como melhor detalhado no capítulo 2.

É digno de nota que essas mulheres, cuja luta é a própria materialização do conceito de Cidadania Ativa evocado nessa tese, ao lutar por melhores condições de vida, suas, e também pelos direitos das crianças, pois suas reivindicações conferiram maior visibilidade social a condições políticas de tratamento da infância nos espaços públicos, contribuíram a reverter um quadro de uma cidadania incompleta, acessado também pelas crianças brasileiras. Ainda que, conforme a tese de Pena (2015), fosse comum que as lideranças dos movimentos de creche se vissem capazes de gerir o atendimento das instituições, por conhecerem as especificidades do público e do local que a instituição se instalasse, isso não diminuía o fôlego das lideranças em buscar melhorias desses serviços, como a reivindicação incessante por uma formação profissional adequada para as/os educadoras/es, já que a educação é direito das crianças, desde o nascimento.

A tese de Pena (2015, p.32-34) também aponta outros elementos que perpassam a questão da educação das crianças. Discussões sobre currículo, propostas pedagógicas e a organização dos espaços e dos tempos e, com grande ênfase, o reconhecimento da 
necessidade de que as pessoas que se responsabilizam pelo cuidado e educação das crianças em Instituições de Educação Infantil deveriam contar com escolaridade elevada e formação específica para o trabalho passaram ao centro dos debates na área. Sobre a formação docente, a professora brasileira Jane Felipe, ao tecer proposta pedagógica publicada no boletim Salto para o Futuro - Educação para a igualdade de gênero (2008), é categórica em afirmar a relevância da formação docente e da escola como locus formador de sujeitos, no que se torna crucial o debate sobre as desigualdades formadas em torno das relações de gênero. A esse respeito, Felipe (2008) assinala que, em ambiente escolar

[...] os efeitos dessa construção minuciosa, contínua e quase imperceptível das identidades de gênero e das identidades sexuais podem ser sentidos nas falas das crianças, dos/as professores/as, das famílias, etc., nas atividades propostas, no incentivo ou proibição de determinados comportamentos, nos silêncios, nas formas de olhar e sentir, nas sanções. (FELIPE, 2008, p.5).

Felipe (2008) analisa, assim como apurado em dissertação de Mestrado de Ramos $(2016)^{33}$, que, por vezes, o corpo docente se sente despreparado para discutir com as crianças as situações cotidianas em que o gênero se faz presente. Na Educação Infantil, é comum que as professoras tenham dúvidas em abordar o tema em receio a não receptividade por parte das famílias (FELIPE, 2008; RAMOS, 2016). No entanto, Felipe (2008) assevera que é fundamental a desconstrução de práticas sexistas, uma vez que a escola não deveria ser instância a contribuir com reforços de preconceitos e desigualdades. Assim como a citada autora, essa tese concebe a escola como lugar de acolhimento e de aprendizados, ampliando os conhecimentos de todas as pessoas.

Trata-se, portanto, de uma busca por superação da forma dissociada com que as atividades relacionadas aos cuidados básicos, e aquelas consideradas especificamente educativas, foram tratadas ao longo da história. Dessa forma, a expressão educar e cuidar poderia consolidar o que se prescreve como funções da Educação Infantil. Segundo Pena (2015), "as relações de cuidado e educação também se evidenciam a partir da ideia de compartilhamento da educação e cuidado das crianças com as instituições”, em conjunto com as famílias, cuja prática ao recriar a cultura, poderia interpelar de outras maneiras as identidades e o desenvolvimento das habilidades de todas as pessoas que, pela lei maior,

\footnotetext{
${ }^{33}$ RAMOS, Maria Rita Neves. Relações de gênero e docência na Educação Infantil: interfaces entre políticas públicas e abordagens pedagógicas. Juiz de Fora, 2016. Dissertação (Programa de Pós Graduação em Educação) Universidade Federal de Juiz de Fora.
} 
deveriam estar comprometidas. Em outras palavras, socializações distintas, em perspectiva feminista, por exemplo, podem reconstruir a maternagem.

Essa outra forma possível de olhar as relações de cuidado e Educação representa um diálogo com o conhecimento científico, mais precisamente com "os padrões de socialização das crianças, interferindo nos modos de vida familiares". A família, ainda pouco à vontade, pois distante da instituição escolar, em muitos casos, busca estabelecer parcerias e cooperações, "não mais está no lugar de vítima, dos que "não têm", e também busca escapar do lugar de consumidora, ou seja, daquela que precisa ter, sem construir" (PENA, 2015). Está colocado o desafio de se estabelecerem entendimentos para a educação e cuidado que deem conta da necessidade no contexto atual, em diálogo com as necessidades mais particulares estabelecidas nas configurações sociais e contextos das famílias e comunidades. Compreendese que é importante estabelecer um diálogo contínuo com as famílias e com os saberes advindos das camadas subalternas, de modo a selecionar um patrimônio afetivo, social e cultural como conteúdo da relação com essas crianças, que será coletivo, e não individual, como no ambiente doméstico (PENA, 2015, p.34).

Sobre a relação entre escola e famílias, a dissertação da professora brasileira Raquel Santiago de Souza (2017) intitulada Família e escola: estudos de uma relação (in) delicada a partir das relações de gênero analisa as instâncias de comunicação entre famílias e escolas. Além de enfatizar a importância do diálogo no compartilhamento da educação, dimensão defendida por essa tese, o trabalho citado apura, por meio de observações e revisão bibliográfica, que as mães são, de forma unidirecional, demandadas a participar e assumir responsabilidades concernentes ao cumprimento das rotinas escolares das crianças. De modo análogo à perpetuação de ideologias conservadoras já expostas nessa tese, o trabalho de Souza (2017) também aponta o quão perversa pode ser a relação famílias-escola, já que, a partir de realidade pesquisada, as escolas persistem em adotar posturas preconceituosas, ao direcionar e cobrar posturas que idealmente as mães devam corresponder. A escola, conforme Souza (2017), imprime o olhar de incapacidade, ao culpabilizar as mães pelos (in)sucessos na trajetória de suas/eus filhas/os, sem demandarem as mesmas obrigações dos pais, homens, sendo essa uma outra faceta desafiadora à consolidação da maternagem.

Já o debate em torno da formação das(os) profissionais para atuarem no cuidado e educação das crianças em creches e pré-escolas se fez, e ainda se faz, de modo a construir referências sobre os saberes, as habilidades e as disposições legais. Refletindo sobre o perfil do profissional para atuar nessa etapa da educação básica, ainda no contexto da década de 
1990, Erica Pena (2015, p.38) assevera que, “tanto em um serviço considerado de tipo assistencial, quanto naquele caracterizado como educacional, a criança estará recebendo algum tipo de educação, evidentemente com experiências pedagógicas diferenciadas". Acrescenta ainda que, historicamente, o primeiro tipo de atendimento contou com pessoas com baixa escolaridade e sem formação específica para o trabalho em Educação Infantil, e o segundo contava com profissionais que, em geral, foram formados para atuarem em instituições eminentemente escolares para a efetivação dos direitos de bebês e crianças pequenas (PENA, 2015). Logo:

[...] a definição $\mathrm{da}(\mathrm{o})$ professora(professor) como a(o) profissional responsável por tais ações, abrangendo cuidados com o corpo da criança e com o ambiente educativo, trouxe para o campo da educação e para a própria categoria profissional professor novos elementos que não estão sendo absorvidos sem conflitos. Atividades claramente entendidas como de cunho pedagógico, ainda que pouco presentes no Ensino Fundamental, são compreendidas e apropriadas como parte do trabalho docente na Educação Infantil. Já as atividades de cuidado encontram resistências por parte desse grupo profissional, desde os processos de formação até a organização, por parte de instituições educacionais, de carreira ou de divisão de funções que segmentam o que se entende por cuidado e o que se entende por educação (PENA, 2015, p.39).

Com base na Sinopse sobre Professores da Educação Básica no Brasil, que sistematiza dados do Censo Escolar de 2007, Pena (2015) nos alerta que são 97,9\% e 96,1\% de mulheres exercendo as funções docentes na creche e na pré-escola respectivamente, contra $81,9 \%$ para a Educação Básica. A autora observa que "a regulamentação do atendimento com o estabelecimento de regras para formação profissional não alterou o quadro de função predominantemente feminina, com baixíssima atração de professores homens". Com base nesses dados, Pena (2015) conclui que as etapas dos cuidados que fazem parte do trabalho docente remetem a conhecidas práticas construídas "com base na relação mulher-criança e, também, na atribuição do cuidado ao trabalho feminino", e que isso constitui uma regularidade social. Outro ponto é que "remete-nos às origens da propriedade privada e do capitalismo, quando convertidas todas as riquezas em propriedades particulares das famílias, instalou-se a forma de família monogâmica, capaz de garantir as heranças e a propriedade das mulheres por parte dos homens" (PENA, 2015, p.40). Isso nos instiga a pensar sobre as origens das vulnerabilidades a que as mulheres estão expostas no tempo atual, como o controle financeiro e os conhecidos conflitos relacionados aos pagamentos de pensões, 
também conhecidos como violência patrimonial, bem como o desmerecimento da realização dos trabalhos domésticos e a resistência social à desvinculação da esfera reprodutiva.

$\mathrm{Na}$ esfera do trabalho, a Educação Infantil geralmente conta com um perfil de trabalhadoras mulheres, com baixa instrução, as quais estão "dispostas" não só a limpar, alimentar, evitar riscos, cuidar das(os) bebês e educá-las(os), como também a se submeter a condições precárias de trabalho. Rosemberg (2011) pondera que esse é o nível escolar com o maior percentual de mulheres $(93,9 \%)$, negras (48,0 \%), com escolaridade não superior ao ensino médio (42,0\%), que dispõe de rendimentos de até três salários mínimos. Maria Malta Campos (1994) já na década de 1990, identificava uma situação de alta rotatividade e baixa assiduidade no trabalho das trabalhadoras da Educação Infantil. Campos (1994) também analisa que a qualidade do desempenho dessas profissionais se relacionava mais com características individuais de personalidade do que propriamente com a formação acadêmica. Discutindo essas questões, o trabalho de Pena (2015) traz uma importante contribuição a essa tese:

\footnotetext{
Ainda que não se possam escolarizar ou formalizar muitas dessas competências, no campo, a não problematização da questão deixa intocadas as sobrecargas de tarefas, a desvalorização dos saberes tradicionais, domésticos e a crença na função maternal (PENA, 2015, p.53).
}

Esse fragmento ilustra um dos questionamentos que essa tese propôs junto às educadoras e gestoras participantes da pesquisa de campo. A naturalização do cuidado interfere de modo considerável na profissionalidade da mulher, perpetuando um ciclo de sobrecargas, além do pouco reconhecimento na forma de desprestígio social e desvalorização do papel de quem desempenha o cuidado, seja na esfera do afeto, respeito ou Educação, no caso das crianças pequenas, o que nos leva ao próximo item.

\subsection{PRÁTICAS DE MATERNAGEM: PENSAR A EDUCAÇÃO PARA ALÉM DOS DITAMES CONSERVADORES}

No Brasil, a professora Dagmar Meyer (2005) analisa os impactos dos discursos dos cuidados sobre os corpos das mulheres-mães, principalmente no que toca ao viés educativoassistencial, o que produz um tipo específico de vínculo mulher-filha/o, e consequentemente, exerce um controle sobre a maternidade que se utiliza, inclusive, do uso de tecnologias que monitoram as dimensões do desenvolvimento fetal e do corpo da mulher. Esse controle faz 
entrar em o choque o papel do Estado e das políticas sociais com os movimentos feministas e de direitos humanos, aprofundando as desigualdades sociais, culturais e econômicas, condições essas agravadas com o processo da globalização (MEYER, 2005, p.84). Nesses termos, a autora analisa a questão da maternidade sob o viés político, tendo em vista que forças sociais atuam diretamente sobre a vida das mulheres, afetando o exercício de seus direitos, já que outras pessoas e entes públicos não são visibilizados na tarefa de cuidar e educar.

A conjuntura apresentada compõe as tensões que dialogam com a consagração das obrigações legais para com a Educação das crianças pequenas, em que o Estado complementa a ação das famílias, em termos de equipamentos e recursos. É um ganho social imensurável, se observarmos que há menos de um século, a educação das infâncias no Brasil era responsabilidade apenas das famílias, paralelamente àquelas que eram abandonadas em orfanatos ou nas Rodas dos Expostos das Santas Casas de Misericórdia, retratada em imagem a seguir. As Rodas dos Expostos (ou Rodas dos Enjeitados) eram dispositivos existentes em mosteiros, abadias e instituições beneficentes. Consistia em um objeto em forma de cilindro, com uma gaveta giratória, em que era depositada a criança que não poderia ser criada pela família. Ao depositar a criança na gaveta, do lado de fora, o objeto era girado, ao que a gaveta com a criança ia para o lado de dentro da instituição. Ela era então recolhida e cuidada nesse local. A primeira Roda dos Expostos chegou ao Brasil, vinda de Portugal, em 1876, e semantiveram operantes, principalmente nas Santas Casas de Misericórdia, até os anos 1950. 
Figura 1. 2: Roda dos Expostos

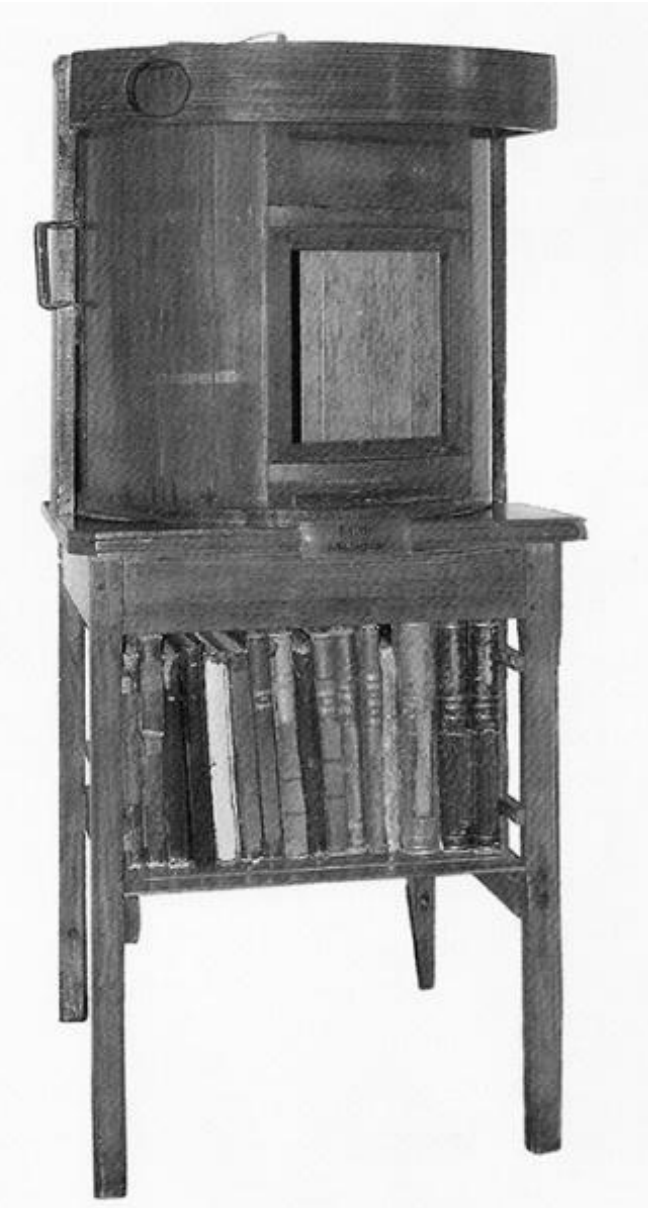

Fonte: https://www.santacasasp.org.br/portal/site/quemsomos/museu/pub/10956/a-roda-dosexpostos-1825-1961. Acesso em 13/12/2019.

O avanço que constitui a Lei de Diretrizes e Bases da Educação Nacional (BRASIL, 1996), na prescrição de que a Educação Infantil passa a ser considerada como a "[...] primeira etapa da educação básica, tem como finalidade o desenvolvimento integral da criança até seis anos de idade, em seus aspectos físico, psicológico, intelectual e social, completando a ação da família e da comunidade" (Art.29) é indiscutível, pois configura um reconhecimento formal, mas ainda a ser efetivado, já que muitas problemáticas ainda existem, como somente as mulheres serem demandadas nessa obrigação, seja pelo aparato institucional, quanto pelas socializações primárias, ainda influenciadas pelas relações de gênero conservadoras, como exposto nesse capítulo e na introdução da tese.

Outra questão importante é a formação das profissionais que atuam em creches e escolas de Educação Infantil. Tema de debate intenso, justamente pela responsabilidade para com as finalidades sociais desse nível de ensino. A formação docente é uma das perspectivas 
que essa tese pretende contribuir, já que existe legislação que prescreve tanto as responsabilidades com a Educação quanto os entes envolvidos nesses processos. Nesse sentido, entendemos a maternagem como uma prática e manifestação de justiça e de resistência aos retrocessos naturalistas de atribuir à mulher a inteira obrigação em educar as crianças, como já mencionado. Mesmo sendo prática cuja reconstrução é possível, ao se estender à qualquer pessoa, como debatido por Nancy Chodorow (1990), entendemos que, com a maternagem, leva-se a termo, também, os direitos de proteção da criança, o que concretizaria as disposições legais que localizam outros entes além da mãe, mesmo com indícios que apontam que ela está relacionada às experiências das mulheres, da maneira como se coloca histórica e socialmente em nossa sociedade.

Em todas as classes, mas mais fortemente nas classes populares, a maternagem usualmente nunca é algo solitário. Quase sempre estabelece diálogo com outras mulheres, como apresentado no texto Ser mulher, mãe e pobre, de Cláudia Fonseca (2000). A histórica dificuldade de acesso às creches pelas camadas populares foi mencionada pelas participantes dos encontros formativos, inclusive interferindo na decisão de se tornarem mães, justificando: "ah, não posso ter filho, porque eu não tenho ninguém que me ajuda". Analisando as situações e dinâmicas familiares do início do século XX no Brasil, Fonseca (2000, p.534-536) localiza como a precariedade dos laços conjugais, assim como o abandono e o contexto econômico precário acessado pelas camadas populares- ainda pior para as mulheres - permeados por um moralismo racial e classista contribuem para tirar a experiência materna do isolamento do lar, situando-a em redes sociais de mulheres. Mães, avós, criadeiras e mães de criação fazem parte dessa sociabilidade, em uma "coletivização" da responsabilidade com as crianças. Essa reconstrução histórica rompe com as expectativas misóginas em continuamente sobrecarregar as mulheres em tentativas de devolvê-las aos espaços privados do lar e da família. Nessa perspectiva, a presente tese, ao identificar a maternagem como uma experiência relacional, observa que esta, quase sempre, ocorre em encontros de mulheres, cuja associação rompe com $\mathrm{o}$ ato solitário da maternidade idealizada.

Considerando as condições de pluralidade de cada contexto e de cada mulher condição econômica, social, faixa etária e outras - entendemos que ocorre, da experiência da maternagem, tanto a emancipação das mulheres quanto a educação das crianças. Primeiro porque as crianças são locus de encontro delas, que continuamente, nas palavras de Fonseca (2000) são responsáveis por "acionar estratégias" para criar suas/eus filhas/os, praticando a importância da família extensa. Ao mesmo tempo, tais vivências, ao acontecer de maneira 
coletiva, são propositoras de fortalecimento dessas mulheres. Esse contra-processo em muito contribui para a cidadania desses grupos. Essa é uma das dimensões que a presente tese pretende investigar nas relações das creches com a educação das crianças. Como compreende a jurista estadunidense Catherine Mackinnon, no artigo Feminismo, Marxismo, Método e o Estado: Uma agenda Para Teoria (2016), as mulheres, e também os Feminismos, se fortalecem.

Por meio da conscientização, as mulheres compreendem a realidade coletiva da condição das mulheres a partir de dentro da perspectiva dessa experiência, e não de fora. A pretensão de que uma política sexual existe e é socialmente fundamental é alicerçada na pretensão do feminismo para a perspectiva das mulheres e não a partir delas ( Mackinnon, 2016, p. 829).

Aprofundando um pouco mais sobre o processo de conscientização das mulheres, o texto de Jane Felipe, intitulado Scripts de gênero, sexualidade e infâncias: temas para a formação docente nos apresenta uma relação pertinente à essa tese, no que toca à Educação. A professora aponta a primordialidade de a escola favorecer as reflexões necessárias à superação das desigualdades e preconceitos, na formação de "sujeitos críticos e comprometidos com os Direitos Humanos". Ao discutir sobre o conceito do gênero como dimensão pertinente à formação docente, Felipe (2008) aponta que este e outros conceitos podem e devem ser debatidos, por tais construções afetarem nossas escolhas, nos diferentes tempos históricos, em distintas expectativas sociais. Diante disso, todo e qualquer tema pode ser produto de reflexão, pois o debate pode gerar outras formas de enxergar as relações sociais, e no caso das mulheres e das crianças, a suposição dessa tese é a de que outros olhares e arranjos sociais para/ sobre elas possam surgir, como a necessária superação do assistencialismo às crianças pequenas, e a maternagem como materialização da educação como algo social, de responsabilidades de todas/os.

Esse capítulo se encerra com a intenção de apresentar terreno tenso e promissor na real tentativa de materializar os direitos das mulheres e crianças. Este contexto foi, e ainda é, batalhado por movimentos sociais a serem descritos no próximo capítulo. 


\section{2 - MARCOS HISTÓRICOS DOS FEMINISMOS NA LUTA POR CRECHES: DADOS DO BRASIL E DEMAIS PAÍSES}

Este capítulo apresenta os marcos importantes que constituem as trajetórias dos Feminismos na luta pelos direitos das mulheres no Brasil e no exterior. Tais marcos são os direitos das mulheres à participação social e política e as reivindicações pelas creches, discutidos no que compete à organização e lapidação dos movimentos feministas e de mulheres e às nuances das disputas políticas envolvidas nesses processos, que resultaram em mudanças sociais significativas, como em políticas que visibilizaram os direitos das crianças, tanto no Brasil, como na América Latina e Europa. Assim, ao analisar esses elementos, pontuamos como as ações e mobilizações feministas contribuíram em uma perspectiva redemocratizadora. Paralelamente, a visibilidade da educação e dos direitos das crianças também será mencionada, nas maneiras e sentidos com que as crianças foram - e continuam sendo - visibilizadas. Trata-se de um capítulo que tem como cerne central situar como a demanda pelos direitos políticos, direito ao trabalho e direitos sexuais das mulheres se desdobram, afetam a sociedade como um todo, e contam com interferências de influências políticas e interesses econômicos. Tal dinâmica entrelaça-se à Educação, debate esse desenvolvido pelos textos da busca bibliográfica e com os dados coletados em campo.

\subsection{FEMINISMOS E CRECHES NO BRASIL}

A feminista brasileira Maria Amélia de Almeida Teles (2003) nos ensina em seu texto Feminismos no Brasil: trajetória e perspectivas que o século XIX foi rico na busca pelo emancipacionismo. As mulheres buscavam a igualdade de direitos, até, então, mantida na esfera dos valores masculinos. O intuito era a libertação de mulheres e homens do "[...] mito do macho, que os colocam como falsos depositários do supremo poder, força e inteligência" (TELES, 2003, p.52). O movimento sufragista batalhou pelo direito das mulheres ao voto, mas também batalhou por ações favoráveis à abolição da escravatura negra, a defesa de ideais republicanos assim como o pleito do direito à educação das mulheres. Já no século XX, o principal debate foi em torno dos direitos trabalhistas e dos direitos de participação na política.

Em relação às mobilizações de participação política das mulheres no Brasil, Teles destaca a fundação do Partido Feminino no ano de 1910, que reuniu cerca de 100 mulheres na cidade do Rio de Janeiro em passeata pública em reivindicação ao voto feminino e a criação 
da Federação Brasileira pelo Progresso Feminino pela feminista Bertha Lutz, que participou ativamente dos debates, compondo o grupo de juristas que editou o Código Eleitoral em 1932, consolidando o direito de voto às mulheres. Desse modo, as mulheres puderam também se candidatar às vagas de deputadas e integrar, ainda que em pequeno número, as assembleias constituintes e tomar parte das discussões parlamentares (TELES, 2003).

Esse mesmo período de luta sufragista, - segundo o livro Feminismos, que história é essa? de autoria de Daniela Auad (2003) - se desenrola ao lado do ingresso no mercado de trabalho e às instituições educacionais. A esse respeito, a cientista política brasileira Céli Regina Jardim Pinto analisa que o sistema oligárquico da época - vertente ideológica e econômica que se contrapunha ao ideal republicano da Revolução de 30 - gerou interessante tensão relacionada aos feminismos e à Educação. Céli Pinto, em seu livro Uma história do Feminismo no Brasil (2003), pontua que os feminismos surgem no núcleo de famílias cultas. Não que houvesse no seio dessas famílias outras formas de pensar sobre a condição da mulher na sociedade brasileira, mas porque as famílias mais abastadas investiam na formação intelectual de suas/eus filhas/os, o que configura ambiente propício às mulheres acessarem o mundo culto da leitura e valorizarem a educação (PINTO, 2003).

Não menos incipiente às classes mais altas, as vozes das mulheres de classes médias e populares também ecoaram, liderando lutas operárias. Dentre as principais batalhas, as mulheres se manifestaram pela redução da carga horária de trabalho, bem como o fim dos horários noturnos de trabalho para mulheres e crianças, pelo direito à maternidade e pelo pagamento de salários iguais a funções iguais (TELES, 2003). Nessa direção

\begin{abstract}
A constituição das creches colocou em discussão o papel materno versus as condições de vida da mulher pobre e trabalhadora. É neste contexto minado que a creche passou a ser vista como um mal necessário. No Brasil, a creche também teve a finalidade de liberar a mão de obra da mãe pobre e assim garantir a sobrevivência das crianças da classe trabalhadora. Enquanto na Europa as creches surgem visando atender às necessidades das mulheres que trabalhavam no setor industrial, no Brasil essa demanda se dá inicialmente entre as trabalhadoras domésticas, pois aqui a industrialização encontrava-se em seus primórdios de desenvolvimento. (CANAVIEIRA; PALMEN, 2015, p. 33-34).
\end{abstract}

Sobre a interseccionalidade de outras categorias sociais à categoria gênero na esfera do trabalho, Teles (2003) nos adverte oportunamente que a mulher negra é a grande responsável pela sobrevivência da família, quando esta consegue um emprego, ainda que informal. Sobre a mulher indígena, ainda como nos dias de hoje, perdura sobre ela um imaginário ficcional, 
que se assemelha a uma lenda, o que denota uma invisibilização social que dificulta o reconhecimento como uma pessoa.

A mesma autora identifica a especial atuação de partidos políticos em dirigir as mulheres para se organizarem, ainda sob o comando dos homens, em "fazer a revolução" (TELES, 2003). Após a conquista do direito ao voto, Teles analisa que há "uma grande pausa no movimento feminista, no qual as mulheres se mobilizam mais em questões gerais do que específicas, como as 'contra a carestia, em favor da alfabetização, da democracia e pela paz mundial"” (TELES, 2003, p.56). Atentando que a direção ideológica e política era dada por homens, Teles argumenta que tais bandeiras são justas, contudo, as questões "relativas à libertação das mulheres, como autonomia, controle da fertilidade, aborto, sexualidade, orgasmo, orientação sexual" (TELES, 2003, p.57) não foram tratadas nos meados do século XX. Inclusive é fato conhecido que a Federação das Mulheres do Brasil, fundada em 1947, foi fechada pelo presidente Juscelino Kubitschek, após um acordo feito entre homens a título de evitar constrangimentos com a Igreja Católica. Nesse período, as mulheres contavam com a Liga Feminina do Estado da Guanabara, que desenvolvia campanhas contra a carestia e outros problemas, como a falta de água e o despejo (TELES, 2003).

Esse retrocesso culmina no golpe militar, do qual Amelia Teles é testemunha viva. A mesma relata com muita tristeza a manipulação que as mulheres sofreram por parte do governo, aliado aos militares e à Igreja Católica, na ocasião da Marcha com Deus pela Familia e a Liberdade, passeatas ocorridas no ano de 1964 nas cidades de Belo Horizonte (MG), São Paulo e Rio de Janeiro como manifestação contrária a uma suposta ameaça comunista. Com vistas a dar sustentação social aos golpistas, Teles pondera que as mulheres foram direcionadas em um ato de submissão, pois não estavam organizadas de maneira autônoma e consciente a defender os seus direitos específicos e, portanto, a democracia e a justiça social (TELES, 2003). Céli Pinto (2003) nos ensina que os feminismos eclodem em todo o mundo a partir de uma grande efervescência cultural e política iniciadas na década de 1960, geradas, principalmente, a partir das Guerras da Coréia e do Vietnã, que desvelaram todo o conservadorismo e racismo do sonho americano popularizado no american way of life $^{34} \mathrm{e}$ - semelhante ao ocorrido em continente americano - a queda do mito de uma revolução socialista em continente europeu em resistência aos ditames capitalistas. Pinto (2003)

\footnotetext{
${ }^{34}$ Céli Pinto (2003) descreve com maiores detalhes no livro Uma História dos Feminismos no Brasil toda a promessa norte-americana relativa a uma prosperidade econômica associada ao consumo de bens, popularização de eletrodomésticos e de uma moral de família em que a mulher era a feliz rainha do lar.
} 
assegura que tais condições foram fundamentais para que os movimentos jovens se organizassem em propor debates nos espaços públicos, questionando principalmente os valores conservadores, tanto do capitalismo norte-americano, quanto do sonho socialista europeu. Além de vanguarda política, esses movimentos jovens - dos quais os movimentos hippie e beatinik, nos Estados Unidos, e o maio de 1968, em Paris, são os mais conhecidos representam, ainda segundo Pinto (2003), uma vanguarda revolucionária, posto que contestaram as relações de poder e hierarquia nos âmbitos público e também privado.

Já os anos de 1970 são marcados pela luta por ideais igualitários, no que tange principalmente à liberdade sexual foram discutidos em nível mundial. Surge, nesse período, a primeira pílula anticoncepcional, tecnologia aplicada ao controle da fertilidade que possibilitou às mulheres lidarem de outras maneiras com o seu próprio prazer sexual (TELES, 2003). O grande marco histórico do Feminismo no Brasil e no mundo foi a instituição do Ano Internacional da Mulher (1975), profícua oportunidade aproveitada pelas mulheres em se mobilizar contra as ditaduras brasileiras e latino-americanas. Movimentos feministas em todo o planeta frutificam, na visibilidade das mulheres, em ações de militância que denunciam a subalternidade das mulheres discriminadas pelos machismos, propondo desafios nas relações sociais. Mesmo porque as realidades sociais e econômicas levaram as mulheres a assumirem a chefia das famílias e a enfrentarem a competição no mundo do trabalho. "No Brasil, o Feminismo se desenvolve e está diretamente vinculado aos partidos políticos de oposição e dos que defendem os interesses populares e dos trabalhadores" (TELES, 2003, p.59). A mesma autora salienta ainda que, mesmo estimando-se que $12 \%$ das militantes de esquerda fossem mulheres, houve dificuldades dessa vertente política em compreender a importância do debate de questões como a sexualidade e a subjetividade. Amelia Teles atribui tal desafinação à falta de liberdade política do país e à intensificação das desigualdades sociais e econômicas. Vale lembrar que, nessa época, ainda estavam ocorrendo as primeiras sistematizações teóricas sobre o gênero, que permitiram às ciências humanas " [...] demonstrar e sistematizar as desigualdades socioeconômicas existentes entre mulheres e homens, que repercutem em suas vidas pública e privada, ao impor papéis de dominação e submissão" (TELES, 2003, p.52).

Ao lado disso, as mulheres nem sempre contavam com apoio familiar e não dispunham de uma infraestrutura necessária a essa nova realidade, como creches, lavanderias públicas ou restaurantes (TELES, 2003). No Brasil, Teles (2003) destaca que o início das organizações dos movimentos de mulheres nascem nos bairros de periferia e em grupos 
feministas, principalmente nos estados de São Paulo e Rio de Janeiro galgando posteriormente outros nichos, como as fábricas, sindicatos e grupos de mulheres que realizam ações junto à Igreja Católica. A esse respeito, o texto "Iniciativas populares: o movimento comunitário e a educação infantil na Baixada Fluminense", de Edson Cordeiro dos Santos (2015, p.1), ao tratar da trajetória da Educação Infantil Comunitária em municípios da região da Baixada Fluminense, no estado do Rio de Janeiro, situa que "as mazelas sociais, aliadas às necessidades dos direitos negados" compõem o cenário de criação dos movimentos comunitários com a agência das mulheres, que reivindicavam, dentre outros direitos, o da Educação, ao lado de movimentos governamentais e não governamentais. Isso confirma a preocupação das mulheres com os direitos sociais.

Relata-se que os primeiros movimentos liderados por mulheres a ganharem as ruas foram os do Custo de Vida e da Anistia. Mesmo tratando de questões gerais, Teles analisa que a efervescência do Feminismo e as mudanças econômicas que favoreciam a autonomia das mulheres foram fatores que possibilitaram a introdução de discussões específicas, o que é o caso das creches, demanda apontada na pauta do movimento do Custo de Vida. "A bandeira da creche estava presente, mas quando a direção do movimento passou para os sindicalistas (a maioria homens), a creche como reivindicação foi retirada da plataforma política por ser considerada meramente assistencialista" (TELES, 2015, p.26).

Logo, Teles (2015) aponta como marco histórico a criação do Movimento de Luta por Creche no ano de 1979 pelas feministas que organizaram o $1^{\circ}$ Congresso Paulista da Mulher "[...] que teve como objetivo central a criação de creches públicas e gratuitas para crianças de 0 a 6 anos, nos bairros e nos locais de trabalho" (TELES, 2015, p.26). Apesar da rejeição inicial por parte do movimento sindical sobre se ter creche no local de trabalho, e de início as creches funcionarem apenas nos bairros, as feministas não esmoreceram, ao que o movimento teve ganhos imensos. Das 4 creches públicas e gratuitas existentes em São Paulo no ano de 1979, estima-se que "[...] em 1984 passou a ter uma rede de creches com mais de 120 unidades" (TELES, 2015, p.26). Como equipamento público de educação, a creche materializa e divulga a discussão sobre a maternidade, deslocando-a em outras direções. 
Figura 2. 1: Movimento por Creches - São Paulo (1979)

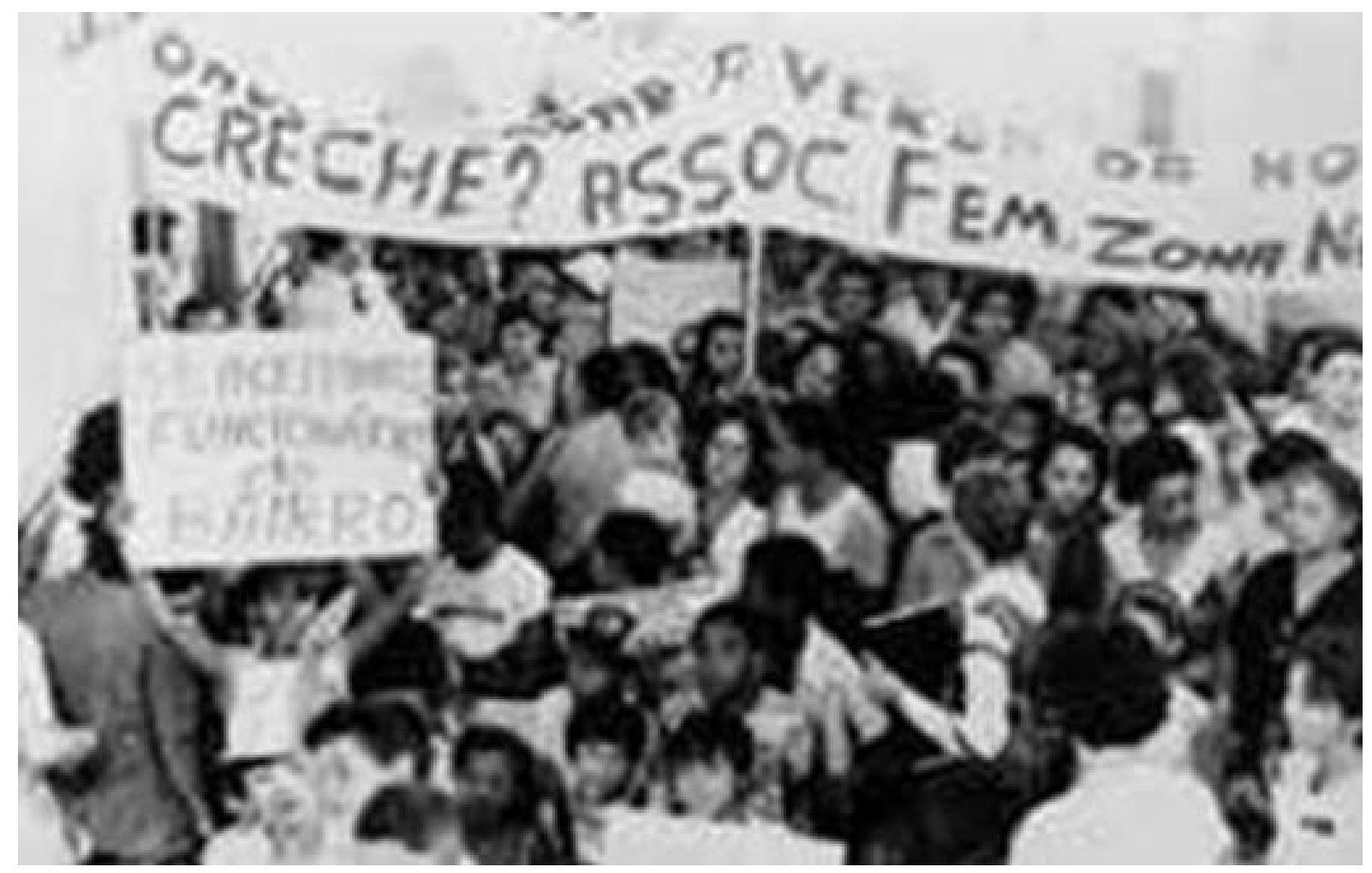

Créditos da Imagem: https://slideplayer.com.br/slide/1701861

Assim sendo, Teles (2015) continua sua análise apontando que “[...] a creche conseguiu unificar o próprio movimento feminista em suas diversas correntes políticoideológicas". Isso porque tanto as militantes feministas, quanto as mulheres operárias da periferia necessitam de um espaço/equipamento para cuidarem de suas/eus filhas/os enquanto trabalham. Assim o feminismo ganha popularidade e a creche ganha o seu lugar de destaque. "Talvez tenha sido um dos momentos em que as feministas saíram dos lugares centrais para a periferia. Com o trabalho popular junto às mulheres, o feminismo adquiriu certa legitimidade e reconhecimento" (TELES, 2015, p.27). Ao lado disso, surgem outros problemas, como o diálogo com o poder público sobre a construção das creches e sobre a qualidade dos serviços prestados, ao que as militantes feministas e os movimentos de mulheres se uniram em discutir esse funcionamento. Detalhando melhor, em termos concretos.

O tempo da criança na creche é maior, o que garante que as mães possam ter um tempo livre para o trabalho e para sua realização pessoal. O tempo da creche não pode ser utilizado apenas paras crianças dormirem, comerem e assistirem televisão. Há necessidade de espaços com sol, terra, água, brinquedos e uma interação entre elas e as pessoas adultas. As mulheres que mais participaram da luta por creche não puderam colocar suas crianças nas creches porque os critérios são voltados para uma população que ganha até 
um ou dois salários mínimos. Assim, muitas mulheres da periferia participaram da criação e manutenção da creche como líderes comunitárias, mas não como mães de crianças das creches. Isto provocou um choque de interesses entre as próprias mães (mães de creche e mães sem creche). $\mathrm{Na}$ medida em que se criava uma creche, apareciam muitas mulheres com suas crianças e naquele equipamento cabia no máximo 120 crianças e não aquelas mais de mil crianças que aguardavam na fila de espera. A falta de creches era uma forma de pressão social e política para rebaixamento da qualidade do serviço, do funcionamento e da atuação dos profissionais, o projeto desenhado por feministas e lideranças populares (TELES, 2015, p.28).

De todo modo, mesmo havendo "[...] um desconhecimento geral do que poderia ser uma creche, do seu significado histórico e do que isso tudo poderia oferecer para as crianças" (TELES, 2015, p.28), a autora afirma que a iniciativa das feministas sobre a demanda das creches contribuiu para as conquistas posteriores. Houve um grande avanço nos debates que se referem às crianças, como o reconhecimento da condição de cidadã na legislação brasileira, reconhecimento inédito à época, o que levou o feminismo a se rever e a conceber a creche também como "[...] um direito da criança pequena à educação, o que não era assim entendido no início da construção da bandeira" (TELES, 2015, p.28). Esse entendimento abriu precedentes para que outras questões fossem também reformuladas, como a pensar a qualidade dos serviços educacionais de modo a prover as necessidades de seu desenvolvimento intelectual, pedagógico, afetivo, além da importância da socialização.

Em contexto educacional, a professora brasileira Zilma Oliveira (2012), em livro de nome $O$ trabalho do professor na Educação Infantil, salienta que após o término dos governos militares, as políticas de educação adquirem o tom de discussão no qual a creche não diz respeito somente às mulheres e às crianças, mas também às empresas e ao Estado. Isso se dá pelas lutas de movimentos feministas e movimentos sociais, como já exposto, e pelos conhecimentos difundidos pela Educação e Psicologia sobre a importância do desenvolvimento infantil nos primeiros anos de vida, abarcando o desenvolvimento linguístico e cognitivo. Segundo essa autora, esse olhar segue coexistindo com as preocupações médicas, como o combate à desnutrição infantil e a amamentação. Agrega-se a esse quadro o questionamento político por parte de educadoras/es, sobre o necessário contraponto das funções pedagógicas e sociais às funções meramente assistencialistas.

Nesse período - década de 1980 e 1990 - nasce a possibilidade concreta de conceber que o trabalho realizado em creches e pré-escolas contribua para o combate às desigualdades sociais (OLIVEIRA, 2012, p.29), em afinação com as discussões sobre justiça social na Educação, expostas por Zeichner (2008). Relembramos que tal conceito equivale ao combate 
às desigualdades sociais pela Educação e, nessa tese, corresponde especificamente à promoção da subversão das desigualdades de gênero, raça, classe e geração, a serem reconfiguradas dentro e fora da escola, com vistas à transformação social. Contudo, Fúlvia Rosemberg (1984), em olhar atento à dimensão de implantação das creches brasileiras, adverte que "[...] a creche se constitui como presa fácil da manipulação ideológica", pois:

O fato de a reivindicação/concessão de creches ter se justificado principalmente pela necessidade /vontade da mãe trabalhar fora de casa, acabou por emprestar à creche o caráter de instituição provisória, de emergência ou substituição, acarretando-lhe uma história cíclica, restringindo-a a apenas uma parte das famílias, dificultando o acúmulo de experiências, tanto em nível de seu funcionamento interno quanto da população usuária (ROSEMBERG, 1984, p.74)

Rosemberg (1984, p. 75) observa que as orientações das políticas de creche não rompem com a vinculação aos "[...] programas de promoção social e ao trabalho materno". Essa visão convive com a procura da compreensão da complexidade psicológica, social, econômica e política da criança cidadã, o que resulta numa tensão entre esta e a "[...] representação idílica da socialização da criança pequena pela maternagem compulsória, não sendo tida como uma instituição de todas as crianças” (ROSEMBERG, 1984, p. 74). Essa não-universalidade, apontada por Rosemberg (1984), pode também corresponder a um não rompimento de olhar conservador, o da cidadania incompleta das crianças, o que é preocupante e grave, uma vez que

Nesse sentido, amplos setores da sociedade não se veem tocados por movimentos em torno da expansão das redes de creche e sua melhoria, na medida em que a instituição nem sempre é percebida como legítima. Ao contrário, muitas vezes a creche é percebida como usurpadora ou competindo com imagens arcaicas (míticas ou não) da mãe provedora. Por outro lado, pode ser tida como instituição de emergência e substituta, respondendo apenas a uma situação circunstancial, a posição que as creches vêm ocupando nos planos governamentais - a verba que lhe tem sido alocada, a previsão de expansão de suas vagas, a criação de serviços que lhes sejam indispensáveis (por exemplo, cursos de formação para seus profissionais) - não corresponde a uma avaliação intrínseca de quais sejam as necessidades da criança socializada nessa instituição (ROSEMBERG, 1984, p.74).

Esse panorama, ainda conforme as pesquisas de Fúlvia Rosemberg (1990), é gerador de uma situação que ainda perdura na atualidade, como a insuficiência de recursos, que, por sua vez, acarreta em um atendimento sem a qualidade necessária, reforçando a creche como 
um "[...] paliativo, um mal menor na experiência de vida de algumas crianças" (ROSEMBERG, 1990, p.74). Esse menosprezo histórico para com a creche se materializa tanto no imaginário social quanto no cuidado dispensado pelos governos às políticas de creche. Isso também foi apontado nas conclusões da Dissertação de mestrado desta pesquisadora, cujo estudo realizado na cidade de Juiz de Fora (MG), apontou a insuficiência de dados sobre o público de crianças e jovens da localidade, o que acarreta em ausência de políticas públicas que dialoguem com as necessidades concretas dessa parcela da população.

Para ilustrar esse argumento, Rosemberg cita o movimento de criação de creches nos Estados Unidos. O maior movimento de implantação das creches observado no citado país ocorreu no período da Segunda Guerra Mundial, a fim de atender às crianças filhas de mulheres que trabalhavam nas indústrias de guerra. Estima-se que à época havia 1, 6 milhões de vagas nas instituições de creches e pré-escolas. Com o fim da guerra, o governo norteamericano retirou o apoio federal aos programas, de modo que houve um encolhimento para o montante de 300.000 vagas em todo o país (ROSEMBERG, 1984, p.74), o que corresponde a um completo descaso para com a figura da criança e também com a mulher.

Em todo o mundo, a década de 1970 foi marcada pela expansão das creches, em muito, pelas propostas de movimentos feministas e movimentos sociais preocupados com questões do cotidiano e com a emancipação da mulher. Salvo algumas exceções, a escassez de cuidados infantis continua sendo problemática em todo o planeta. Serão apresentados nesse momento como outros países da América, além do Brasil, dedicam sua atenção às creches.

\subsection{FEMINISMOS NA AMÉRICA LATINA}

O trabalho das professoras latino-americanas Nancy Saporta Sternbach, Marysa Navarro-Aranguren, Patricia Chuchryk e Sonia E. Alvarez intitulado Feministas na América Latina: de Bogotá a San Bernardo recupera a caminhada dos feminismos na América Latina, a partir da participação na conjuntura política latino-americana na década de 1970 de modo geral, e de modo mais específico retratando os debates das mulheres acessados em Encontros Feministas que se realizaram ao longo das décadas de 1980 até o ano de 1990.

As citadas professoras e feministas localizam a década de 1970 como marco histórico das manifestações feministas em todo o mundo, e também na América Latina. Como já apontado pelo trabalho de Teles (2003), os feminismos latino-americanos se posicionam em contextos assolados por crises econômicas e políticas, em especial os governos militares, em 
movimentos de oposição. Sternbach, Navarro-Aranguren, Chuchriyk e Alvarez (1994) apontam que os primeiros movimentos de criação de grupos feministas surgem não apenas questionando o patriarcado, na forma do estado militarista - no olhar para a família, a opressão sexual e as relações homem/mulher - mas também mobilizaram esforços junto a outros movimentos denunciando opressões sociais, políticas e econômicas, o que expõe fortemente o engajamento sobre a bandeira da luta de classes.

O autoritarismo, proclamavam as feministas, representava "a forma mais elevada" da opressão patriarcal. Como declarou uma feminista latinoamericana, referindo-se ao Chile: "A Junta, com um sentido muito claro dos seus interesses, entendeu que devia reforçar a família tradicional e o papel dependente das mulheres, que é reduzido ao de mãe. A ditadura, que institucionaliza a desigualdade social, é fundamentada na desigualdade na família" (Sternbach; Navarro-Aranguren; Chuchryk; Alvarez, 1994, p.258).

Sternback; Navarro-Aranguren, Chuchrik e Alvarez (1994) apresentam os contextos de incoerência, repressão e truculência que as feministas enfrentaram e enfrentam na América. As professoras discorrem que tanto nos governos militares, quanto nos civis, os "apelos" aos valores da família tradicional e cristã estavam focados na segurança nacional, na contra insurgência e na política social recessiva. Contudo, se observa um enorme distanciamento entre o discurso estatal e a realidade concreta das mulheres latinas. Enquanto o discurso oficial exaltava a figura tradicional da mulher, impelindo-a à maternidade, os contextos de crise e de políticas econômicas recessivas as empurravam ao mercado de trabalho. Ao lado disso, os aparelhos repressivos de Estado submetiam as mulheres à violência e exploração sexual, o que não se harmonizava com as falas dos governos. $O$ final da década de 1970 foi marcado por muitos movimentos reacionários que contaram com ampla adesão de mulheres, pertencentes a todas as classes sociais que "[...] desafiaram sua exclusão histórica das coisas políticas e uniram-se à oposição em números sem precedentes" (STERNBACH; NAVARRO-ARANGUREN; CHUCHRYK; ALVAREZ, 1994, p.259). No Brasil, Santos (2015) analisa que, mesmo o país estar sob um regime autoritário, como já mencionado pro Teles (2015), notou-se uma mudança em termos de participação popular, que ocupou um espaço até então só ocupado pelas elites, ainda que não por uma democratização social, mas como uma estratégia de legitimação dos Governos Militares. De todo modo, é pertinente salientarmos que isso representa um ganho, em termos de visibilidade, em tempos tão hostis. 
Na década de 1980, no Peru, as mulheres fizeram parte das lutas rurais de base. Nesse mesmo período, ficaram mundialmente conhecidas as mobilizações femininas no Brasil, Argentina, Uruguai e Chile, manifestando-se a favor da democracia e dos direitos humanos. Sobre o engajamento político das feministas latino-americanas, as mesmas professoras destacam que:

Como na América do Norte (Canadá e Estados Unidos) e na Europa Ocidental, então, o feminismo de segunda leva na América Latina nasceu da "Nova Esquerda". Mas, como a oposição progressista era dominada pelo machismo e sua prática sexista, as mulheres e "seus problemas" eram invariavelmente relegadas a uma posição secundária nos movimentos progressistas e revolucionários. [...] as latinoamericanas mantiveram firme $o$ compromisso com a mudança radical nas relações sociais de produção - e de reprodução - enquanto continuavam a combater o sexismo no seio da esquerda (STERNBACH;NAVARRO-ARANGUREN;CHUCHRYK; ALVAREZ, 1994, p.260).

Obviamente, as bandeiras das feministas se aproximavam dos setores opositores, como o combate à pobreza e às desigualdades sociais, mas não sem consequências para suas manifestações. Sternbach, Navarro-Aranguren, Chuchryk e Alvarez (1994) avaliam que os movimentos de esquerda influenciaram muito o início dos movimentos dessas mulheres, que chegaram a privilegiar a questão das classes ao gênero, afastando-as de suas demandas específicas, semelhante ao ocorrido em contexto brasileiro. Influenciadas pelo legado marxista, leninista/guevarista, as mulheres da América Latina foram se tornando “[...] a vanguarda do que viria a se tornar um movimento de mulheres revolucionário, com base nas massas e interclasse" (STERNBACH; NAVARRO-ARANGUREN; CHUCHRYK; ALVAREZ, 1994, p. 261). Além dos desejos de emancipação, autonomia, independência e dignidade, adquiridas pelo acesso aos direitos e a satisfação das necessidades, fica evidente, a partir da análise das autoras, o quão presente é o componente da solidariedade nas lutas das mulheres, ainda que perpassado por variados conflitos e obstáculos.

A "retaguarda", neste panorama, viria a ser formada por centenas de grupos de mulheres da classe operária que então proliferavam em grande parte da América Latina. As crises econômicas levaram as mulheres da classe operária a desenvolver criativas estratégias de sobrevivência coletiva. Muitas vezes sob a tutela da Igreja Católica e da esquerda masculina, formaram-se grupos de mulheres em nível de bairro para prover as necessidades básicas da vida, uma responsabilidade consistente com os papéis femininos tradicionalmente definidos. Dentro de suas responsabilidades socialmente atribuídas como esposas, mães e provedoras da família e da comunidade, as mulheres assumiram a liderança nas estratégias de resistência do cotidiano 
das classes populares da América Latina. Em cada país da região, elas têm participado de modo desproporcional em movimentos para assegurar melhores serviços urbanos, protestar contra o aumento do custo de vida e assegurar assistência médica e educação a seus filhos, A tortura, os desaparecimentos e outras formas de repressão política também uniram mulheres de todas as classes sociais na organização de movimentos pelos direitos humanos (STERNBACH; NAVARRO-ARANGUREN; CHUCHRYK; ALVAREZ, 1994, p. 261).

Conforme os estudos de Sternbach, Navarro-Aranguren, Chuchryk e Alvarez (1994), o movimento inicial das feministas latino-americanas foi o de dedicar esforços em organizar as mulheres operárias pobres em um amplo movimento de lutas comunitárias pela sobrevivência "[...] fomentando ao mesmo tempo a consciência de como os papéis sexuais moldavam seu ativismo político" (STERNBACH; NAVARRO-ARANGUREN; CHUCHRYK; ALVAREZ, 1994, p. 261). A postura das feministas, em priorizar a esfera do trabalho a questões como a sexualidade, relações familiares, poder e reprodução, se justificou pelo receio em alienar a grande massa de mulheres e de se ver perdida a legitimidade do movimento perante os companheiros de luta "macho leninistas", que concebiam o feminismos como sendo de uma vertente "boa" (que privilegiava a luta de classes) e uma vertente "ruim" (um feminismo importado e burguês, exemplo de um imperialismo ideológico). Sobre isso, as autoras esclarecem que:

Ainda hoje, em muitas organizações populares de mulheres ligadas à Igreja
Católica progressista da esquerda, elas são continuamente advertidas contra
a adoção de crenças feministas "ruins", como o direito ao aborto e à livre
determinação sexual, vistas como intrinsecamente burguesas e prováveis
"divisoras" da luta unida da classe operária. É significativo, portanto, que
muitos grupos de mulheres da zona rural sejam subvencionados ou
controlados pela Igreja ou pela esquerda, enquanto, junto com a mídia,
religiosos e ativistas masculinos seculares tergiversam e deturpam o sentido
e o caráter do feminismo, muitas vezes obstruindo deliberadamente o
desenvolvimento de uma consciência sexual crítica entre as participantes dos
movimientos de mujeres. Isto, em muitos casos, explica a reticência de
mulheres nessas organizações a incorporar o rótulo de feminista, mesmo
quando comungam crenças feministas. Ou seja, essa relutância não é um
resultado "natural" de suas posições de classe. (STERNBACH; NAVARRO-
ARANGUREN; CHUCHRYK; ALVAREZ, 1994, p. 262).

Ao longo de movimentos de aproximação e diálogo, as feministas conseguem perceber o quanto é contestável e machista a argumentação da esquerda com relação a um feminismo bom ou mal. Questões relativas à sexualidade e outros temas interessam às mulheres tanto quanto as preocupações relacionadas à sobrevivência e ao trabalho. Os partidos de esquerda também impunham às mulheres a sua própria agenda política, interferindo em sua 
organização enquanto movimento, dizendo que "o sexismo desapareceria após a Revolução". Diante de conduta manipulatória, as mulheres passam a argumentar sobre a nocividade que essas tentativas de imposição, o que lhes rendeu objetividade no debate à esquerda. Esse entendimento fez o feminismo avançar em termos de teoria, prática e identidade política (STERNBACH; NAVARRO-ARANGUREN; CHUCHRYK; ALVAREZ, 1994), o que podemos observar pelo crescimento do contingente de mulheres que acessam as discussões de modo parlamentar, e pela adoção do conceito de gênero em várias agendas políticas atuais, como as políticas de saúde da mulher, da esfera jurídica e da Educação.

Muito em resposta ao posicionamento da esquerda latino-americana em rejeitar as formas de imperialismo, Sternbach, Navarro-Aranguren, Chuchryk e Alvarez (1994) ponderam sobre a grande preocupação das feministas em enfatizarem a dimensão da especificidade de suas lutas. Com relação à saúde da mulher, as feministas não focam somente na questão do controle e direito ao corpo, mas também alertam sobre o sentido da "[...] compreensão de como as organizações internacionais e empresas multinacionais determinam as políticas de saúde e de população nacionais em seus países", em clara luta anticapitalista. Sobre a violência sexual contra a mulher, as feministas denunciam a especificidade do contexto latino americano, em que as mulheres prisioneiras políticas são submetidas à tortura sexual.

Assim sendo, o feminismo na América Latina, assim como em outras partes do mundo e no Brasil, atuou em "[...] uma ampla variedade de formas organizacionais e combate à opressão feminina em toda a gama de arenas políticas, econômicas e culturais." (STERNBACH; NAVARRO-ARANGUREN; CHUCHRYK; ALVAREZ, 1994, p. 262). As autoras atestam que as manifestações de ação feministas latino-americanas caminhavam "[...] conclamando a uma revolução na vida diária, afirmando que uma transformação social radical tem de abranger mudanças não apenas nas relações de classe, mas igualmente nas de poder". Cada vez mais se faziam críticas às formas e estilos de "fazer política", típicos dos grupos revolucionários dominados por homens, no que as feministas, de modo a buscar a mudança social radical, contrapunham sistemas mais participativos e democráticos.

Dessa evolução, surgem os Encontros Feministas, com o objetivo de discutir em fóruns a política feminista voltada à justiça social na América Latina, assim como espaço de fortalecimento e troca de troca de experiências para dar unidade ao ideal comum dessas mulheres. 
Os Encontros Feministas latino-americanos e caribenho teve sua primeira edição no ano de 1981, em Bogotá, na Colômbia. Sternbach, Navarro-Aranguren, Chuchryk e Alvarez (1994) relembram que, naquela ocasião, foi possível dimensionar a amplitude do alcance do Feminismo. Esse encontro contou com a participação de delegações provenientes do México, Brasil, República Dominicana, Porto Rico, Colômbia, Panamá, Curaçao, Venezuela, Equador, Peru, Chile e Argentina.

\begin{abstract}
Algumas participantes eram jovens universitárias; outras, organizadoras mais velhas, das classes operárias. Eram arquitetas, médicas, professoras, advogadas, funcionárias públicas, trabalhadoras rurais, poetas e cineastas. Vinham dos centros de mulheres agredidas, organizações camponesas, grupos de pesquisa, mulheres que trabalhavam nas favelas das grandes cidades da América Latina, em coletivos de cinema e revistas feministas. (STERNBACH; NAVARRO-ARANGUREN; CHUCHRYK; ALVAREZ, 1994, p. 265).
\end{abstract}

Como era de se esperar diante de tal pluralidade, o Encontro de Bogotá foi palco de intensos e conflituosos debates com prioridades divergentes, que demonstraram "[...] concepções radicalmente diferentes sobre a luta de gênero na América Latina e Caribe na última década" (STERNBACH; NAVARRO-ARANGUREN; CHUCHRYK; ALVAREZ, 1994, p. 266). As autoras analisam que os primeiros embates surgiram logo na organização do evento, sobre qual público o encontro se direcionaria: as feministas ou todos os grupos de mulheres? De base individual ou com representação organizacional? Para sanar essas questões, a organização convocou uma reunião nacional para tratar desses tópicos. Em votação, o Encontro decidiu abrir suas atividades " [...] a todas as mulheres 'engajadas na luta por sua liberação' e tornar a representação das organizações e partidos políticos a base da participação". Da realização do Encontro propriamente dito, as mesmas estudiosas dizem que:

Na seção mais amplamente concorrida, Feminismo e Luta Política, as participantes concordaram em discutir três tópicos considerados os mais relevantes para as feministas latino-americanas: a autonomia (independência política ideológica e organizacional) do movimento feminista; dupla militância, ou participação simultânea e compromissos duplos, com um partido político e o feminismo; e feminismo e imperialismo. As questões em discussão variaram de como ampliar, fortalecer e aprofundar a participação das mulheres dos setores populares, até a forma de fato que deveria assumir um Encontro e as condições específicas da prática política feminista na América Latina. Embora as participantes concordassem em alguns princípios básicos, como por exemplo a existência da desigualdade sexual, divergiram muitíssimo quanto às estratégias que as feministas deviam adotar para acabar com a opressão de gênero (STERNBACH; NAVARRO-ARANGUREN; CHUCHRYK; ALVAREZ, 1994, p. 266). 
Foi ponto pacífico entre todas as participantes do Encontro de Bogotá

[...] que as mulheres sofrem uma opressão específica, que se torna particularmente aguda nas classes mais exploradas. As mulheres, portanto, precisam articular-se e lutar por suas exigências específicas: o fim da dupla jornada, pagamento igual por trabalho igual, direito de trabalhar, direito de fazer aborto e "maternidad libre y voluntaria" (STERNBACH; NAVARROARANGUREN; CHUCHRYK; ALVAREZ, 1994, p. 268).

As feministas também diagnosticaram que tais questões não haviam sido incluídas nas plataformas de partidos, movimento político que ocorreu também no Brasil, já debatido nesse capítulo pelo olhar de Teles $(2003 ; 2015)$. Ao lado disso, foi possível identificar duas posições que dividiam as ativistas do movimento feminista, "[...] independentemente do país de origem, classe ou status de educação". Sternbach, Navarro-Aranguren, Chuchryk e Alvarez (1994) analisam que a primeira vertente tinha o entendimento que nem o capitalismo, tampouco o socialismo poderiam, de maneira isolada, eliminar a opressão sofrida pelas mulheres, o que exige das mulheres uma mobilização em movimento independente de qualquer partido. Segundo esse posicionamento, “[...] o feminismo representava um novo projeto revolucionário, a primeira alternativa para a transformação total das relações sociais opressivas na América Latina”. Assim, concebendo a ação política dos feminismos, as feministas adeptas sugerem outra leitura sobre a dicotomia convencional entre feminismo, militância e ativismo político. "Rejeitaram o uso do nome militantes ou políticas em oposição a feministas, porque viam o feminismo como uma prática política legítima e abrangente". Para elas, as feministas deviam atuar em suas próprias organizações feministas. Entretanto, algumas defenderam a possibilidade de estabelecer alianças com partidos políticos em busca de metas especificas. (STERNBACH; NAVARRO-ARANGUREN; CHUCHRYK; ALVAREZ, 1994, p. 269).

A esse respeito, compreendemos que, apesar das especificidades, a forma de manifestação e engajamento das mulheres ocorrem em termos de espaço de interlocução. Isso se dá mediante a dimensão da "presença", de uma e de seu outro, ou outra, o que, segundo o professor Jader Janer Moreira Lopes (2008, p.80), em seus estudos sobre Geografia da Infância, coloca a Geografia como uma lupa possível a ler a configuração de ação e participação social das crianças, na simultânea construção de lugares e também não-lugares.

A noção espacial, como parte integrante dos sujeitos, seria assim uma noção social, uma construção semiótica, constituída a partir do contexto cultural no qual se está inserido. Apresenta, portanto, um caráter ideológico e semiótico, 
sem o qual não existirá para as pessoas, corroborando dessa forma a construção de nossas subjetividades (LOPES, 2008, p.76).

Considerando tal pressuposto, torna-se possível estender a materialização das ações das crianças, como conformadoras de territórios de infâncias, à materialização das ações das mulheres, como criadoras de territórios democráticos. Pensando o espaço de interlocução promovido pelas mulheres, pelos atravessamentos de distintos interesses, concepções e formar de agir descritos nesse capítulo, tal reflexão se aproxima da definição de território proposta pelo geógrafo Rogério Haesbert (2004, p.79):

[...] a partir da concepção de espaço como um híbrido - híbrido entre sociedade e natureza, entre política, economia e cultura, e entre materialidade e "idealidade", numa complexa interação tempo-espaço, como nos induzem a pensar geógrafos como Jean Gottman e Milton Santos, na indissociação entre movimento e (relativa) estabilidade-recebam estes os nomes de fixos e fluxos, circulação e "iconografias" [na acepção de Jean Gottman], ou o que melhor nos aprouver. (...) o território pode ser concebido a partir da imbricação de múltiplas relações de poder, do poder mais material das relações econômico políticas ao poder mais simbólico das relações de ordem mais estritamente cultural.

Assim sendo, considerando também como fundamental componente da produção do território a dimensão da historicidade, elemento bastante discutido na tese como importante construtor de saberes. Haelsbert (2004) e, também, Lopes (2008) nos instigam a pensar a presença e o território pela ótica e contribuição das mulheres. Quaisquer disputas, ou as distintas ordens dos conflitos descritos pela tese, na multiplicidade dos contextos sociais aqui evocados, produzem territórios, para além de sua existência geográfica. Isso porque todos os debates remetem à construção de uma organização social, política e, também, econômica. Logo, a partir dos conceitos dos citados professores, e ao lado dos escritos de Mouffe (2018), que versam sobre os embates no interior das sociedades democráticas, é pertinente refletir que, a partir da noção de que as disputas políticas estão postas, e que estas conformam as lutas sociais em termos de poder, a presença das mulheres pode ser, em alguma medida, potente à conformação de territórios democráticos, já que contribuem na ampliação dos debates políticos.

Cabe acrescentar que o componente do fortalecimento das mulheres enquanto grupo, assim como descrito nas movimentações feministas brasileiras e latino-americanas no presente capítulo, também é reconhecido pelas participantes da pesquisa de campo, que relataram que "como que todas elas se ajudam e tentam mudar as coisas, superar as 
dificuldades, e como o apoio é importante porque quando uma mulher fala alguma coisa e outra fala e vai também isso ajuda". Além disso, quanto maior a participação, em uma sociedade democrática, maior é a deliberação, o que, segundo Mouffe (2005), torna vibrante as possibilidades de interpretação das realidades. Sobre isso, a autora enfatiza que "a estabilidade e a ordem resultariam mais provavelmente do compromisso entre interesses diversos do que da mobilização do povo em direção a um consenso ilusório acerca do bem comum" (MOUFFE, 2005, p.12).

Sternbach, Navarro-Aranguren, Chuchryk e Alvarez (1994) ressaltam que havia mulheres que "[...] insistiam em que o feminismo em si e por si talvez não fosse um projeto revolucionário. Devido ao seu compromisso básico com o socialismo, elas argumentavam que o feminismo não devia ser separado do partido, mas ter autonomia orgânica naquela estrutura". Sob essa ótica, as feministas compreendiam que não deviam separar-se dos objetivos da classe operária “[...] e de sua luta para acabar com a opressão de classe”. Ainda que reconhecessem as dificuldades práticas de ser feminista no âmbito de um partido político, elas entendiam que tais problemas não eram insuperáveis. No término do Encontro, os fóruns deliberaram sobre muitas resoluções, em termos de manifestações de "[...] solidariedade a mulheres de países específicos (Chile, Colômbia, Guatemala e as Mães da Plaza de Mayo, da Argentina), e com lutas nacionais específicas (Nicarágua e El Salvador)”.

Sobre questões de cunho mais amplo, realizaram-se debates sobre "[...] pagamento igual por trabalho igual, direitos de reprodução, cuidado de crianças, melhoria educacional e direito ao trabalho". No que toca ao tema da violência contra as mulheres, foi declarado o dia 25 de novembro como o Dia Internacional da Não Violência contra Mulheres, em homenagem à memória das irmãs Mirabal ${ }^{35}$, mulheres dominicanas mortas no ano de 1960 (STERNBACH; NAVARRO-ARANGUREN; CHUCHRYK; ALVAREZ, 1994, p. 269). Não é apontado nos relatos das autoras que se tenha abordado o tema das creches nesse Encontro, mas a responsabilidade com as crianças foi abordada.

A segunda edição do Encontro Feminista realizou-se em Lima, no Peru, em 1983, e contou com a participação de cerca de 600 feministas. A temática central do segundo Encontro destacou os impactos do patriarcado, tema que é considerado controverso pelas mulheres e homens não feministas. Acirrou-se nessa oportunidade a divisão entre as

\footnotetext{
${ }^{35}$ Maria Teresa, Minerva e Patria Mirabal foram ativistas políticas que lutaram contra a ditadura de Rafael Trujillo, na República Domicana, brutalmente torturadas e assassinadas pelo regime trujilista. Fonte: https://aventurasnahistoria.uol.com.br/noticias/vitrine/historia-caso-irmas-mirabal.phtml Acesso em 17/09/2020.
} 
feministas e os movimentos de mulheres, pois "[...] as participantes se conscientizaram política e estrategicamente de que ser feminista e trabalhar com mulheres não eram necessariamente a mesma coisa" ${ }^{\text {36 }}$ (STERNBACH; NAVARRO-ARANGUREN; CHUCHRYK; ALVAREZ, 1994, p. 270). De todo modo, se repete a presença do grande número de mulheres de todos os países da América Latina nessa iniciativa, o que denota o alcance dos feminismos, e a identificação delas com as bandeiras dos movimentos, ao lado de outras demandas específicas visibilizadas na ocasião.

\begin{abstract}
Vários workshops que não faziam parte do programa original representaram um significativo afastamento das compreensões marxistas convencionais sobre a questão da mulher, e assinalaram a complexidade e diversidade crescentes de lutas consideradas feministas. Pela primeira vez, houve uma resposta pública às exigências das lésbicas de que sua presença no feminismo latino-americano fosse reconhecida. Historicamente, esse workshop assinalou o surgimento da visibilidade lésbica dentro do movimento, e desafiou as feministas heterossexuais a enfrentarem sua homofobia. Para muitas, esta foi uma das conquistas mais significativas do encontro de Lima. Do mesmo modo, o mini workshop sobre racismo, embora não com presença tão maciça, ou tão publicamente visível, proporcionou um fórum para criticar a falta de espaço no Encontro para enfrentar o racismo. Esse workshop, do qual participaram basicamente negras e índias, desafiou o encontro de Lima e os subsequentes a tratar do racismo, não apenas levando em conta as experiências vividas por mulheres em seus variados contextos sociais, culturais e nacionais, mas também dentro do próprio movimento feminista (STERNBACH; NAVARROARANGUREN; CHUCHRYK; ALVAREZ, 1994, p. 272).
\end{abstract}

Ainda que o Encontro representasse avanços importantes na articulação das feministas latino-americanas, Sternbach; Navarro-Aranguren; Chuchryk e Alvarez (1994, p.273) observam que se "[...] estabeleceu, ao mesmo tempo, uma estrutura na qual alguns problemas difíceis pudessem ressurgir mais tarde. A análise do patriarcado e das relações de poder de gênero, por exemplo, deu um novo contexto para o diálogo entre feministas e militantes", colocando em discussão as estratégias feministas a serem adotadas. Outro ponto em questão levantado pelas estudiosas foi a participação daquelas que trabalhavam com mulheres, mas que não se reconheciam como feministas. Isso estabeleceu para o movimento feminista a denominação dos movimentos de mulheres.

\footnotetext{
${ }^{36}$ Essa distinção foi debatida pelas feministas, calorosamente, nos Encontros posteriores, o que será exposto nos próximos momentos do texto. De toda maneira, ainda que com enfoques e teses distintas, pode-se dizer que é feminista quem questiona a sujeição das mulheres, buscando a justiça.
} 
Já em 1985, o terceiro Encontro Feminista, realizado em Bertioga, no Brasil, contou novamente com uma pluralidade étnica e cultural, personificada na ampla gama de atividades, ideologias e formas de organização. Conforme os estudos de Sternbach, Navarro-Aranguren, Chuchryk e Alvarez (1994, p. 274); o feminismo latino-americano tornara-se de fato independente, política e culturalmente, pois “[...] buscavam suas metas numa ampla variedade de espaços institucionais e extra-institucionais", com destaque para a organização do feminismo brasileiro, o mais diversificado, radical e politicamente influente do continente, mesmo sofrendo retaliações e contraofensivas. Foram significativas as discussões sobre as intersecções dos feminismos e as lutas revolucionárias, indicativos do crescimento do movimento e da diversidade que ele criara, novamente sem mencionar as creches.

O quarto Encontro Feminista no ano de 1987 foi sediado em Taxco, no México, reunindo pela primeira vez mulheres da América central e do Sul, além do Caribe e Cuba. Esse evento transcorreu em um novo contexto político, já com os processos de democratização.

\begin{abstract}
As participantes estavam comprometidas com todos os tipos concebíveis de ativismo feminista - político, cultural e educacional. Havia mulheres trabalhando para o Estado, em comissões ou ministérios recém-criados sobre a condição da mulher; "mulheres de partido", que podiam ou não se considerar feministas; sindicalistas (tanto urbanas quanto rurais); e, claro, as dos movimentos de mulheres. Também estavam presentes "trabalhadoras culturais" - mulheres que trabalhavam nas artes, incluindo cineastas e videomakers, escritoras e poetas. Havia ainda as que trabalhavam com projetos especificamente feministas - grupos de apoio a mulheres agredidas, centros de assistência à saúde e centros de documentação feministas - e, pela primeira vez, um significativo número de ativistas feministas católicas. Desta vez, as lésbicas não apenas participaram do Encontro, mas também realizaram seu próprio Encontro imediatamente antes do de Taxco, com a presença de 250 mulheres (STERNBACH; NAVARRO-ARANGUREN; CHUCHRYK; ALVAREZ, 1994, p. 277-278).
\end{abstract}

Diante de tal contexto político, e da ampliação das bases do movimento feminista realizadas pela heterogeneidade dos debates ao longo dos Encontros, Sternbach, NavarroAranguren, Chuchryk e Alvarez (1994) asseveram que o Encontro em Taxco foi palco de muitas tensões e contradições entre o que cada mulher buscava e priorizava nesse espaço. Esse conflito é percebido ainda nos dias de hoje, cujas faces e dimensões de divergência são ilustradas na fala contundente de uma participante veterana:

Temos de encontrar um meio de nos organizar e autofinanciar. Acho que precisamos de Encontros bem menores. Há uma história por trás desses 
Encontros, e não podemos negá-la, nem começar do ponto zero todas as vezes. Na América Latina, os movimentos de mulheres estão crescendo. Estamos chamando isto de um Encontro feminista, e ele se revela um Encontro de mulheres. O movimento feminista não pode permanecer estagnado. Temos de progredir. Nossos Encontros ajudaram a nos revitalizar, e agora não estão mais fazendo isso. Estamos cansadas de ser as 'compafreras agitadoras, ativistas', que têm de explicar porque somos feministas, lésbicas que têm de explicar porque são lésbicas. Estou cansada de me sentir culpada. Na América Latina, precisamos de dois espaços: um para as feministas e outro para os movimentos. Não podemos misturá-los. Bertioga nos mostrou que se podia misturá-los, mas que também precisamos manter certa ordem. Há dois espaços aqui, e cada um tem de ser respeitado. O problema deste Encontro é que quiseram fazer tudo, um grande e belo evento com a participação de todos os países e, portanto, de todos os problemas. Mas não podemos resolver tudo isso aqui. Não podemos nos sentar e conversar sobre países, quero falar como Maria, não como Equador. Não que eu ache que não é necessário conversar sobre o Equador, mas este Encontro foi criado para se falar de Maria, Cecília, Maria Rosa etc., Cada Encontro nos dá um desses estímulos. Portanto, é hora de repensar os Encontros. Se não temos dinheiro, precisamos de espaços menores. E, claro, temos ainda de continuar a nos encontrar, mas (a organização) não deve depender dos trabalhos de só um país, e sim de vários" (STERNBACH; NAVARRO-ARANGUREN; CHUCHRYK; ALVAREZ, 1994, p. 284).

Segundo Sternbach, Navarro-Aranguren, Chuchryk e Alvarez (1994, p. 284-285), essas tensões foram a culminância de uma situação surgida no Encontro de Lima, em que a defesa de um "[...]movimento de base ampla, multirracial e multiclassista" convivia com a "[...] suposição de que a realidade centro-americana não é de fato "feminista" o bastante, sua frustração com a ausência de discurso feminista dos movimentos de mulheres". A esse quadro, somou-se o problema da não existência de espaços em que pudessem ser discutidos os problemas específicos de cada país ou região. Nesse embate, as feministas denominadas históricas asseguravam que somente a organização de mulheres não constituía a prática feminista. Nessa perspectiva, os motivos pelos quais as mulheres se reunissem e se mobilizassem só corresponderiam ao feminismo quando estes fossem relativos aos direitos sexuais, de reprodução ou de violência, ou seja, especificamente relativos às questões de gênero. A essa alegação, houve uma contraposição das mulheres da classe operária, que enfatizaram que "[...] a opressão sexual assume formas diferentes entre mulheres de diferentes classes e grupos étnico-raciais" o que, no ponto de vista delas, coloca problemas como o de abastecimento de água como sendo uma empreitada feminista, já que como socialmente responsáveis pela família, a questão afeta o trabalho das mulheres, perspectiva essa com a qual esta tese concorda. 
Nessa perspectiva se somaram as argumentações das mulheres negras, apresentando outra maneira que o gênero se faz presente, desta vez, combinado com a categoria raça, debatendo a representação da mulata ${ }^{37}$. Movimento semelhante também foi apontado, em momento anterior deste texto, na análise de Teles, ao destacar a forma de a sociedade brasileira invisibilizar a mulher indígena.

A maioria das mulheres insistiu em que a diversificação de arenas de luta feminista representava um avanço para o movimento. Pareciam estar desenvolvendo um conceito revisado de dupla militância: em vez de levar a linha de seu partido para uma organização feminista, a mulher podia levar a linha feminista para dentro de seu partido, sindicato, organização de bairro, ou para seu trabalho. Esta reformulação da prática feminista, argumentavam, seria mais apropriada numa época de regimes democratizantes e extensa mobilização política popular. Um movimento feminista de base, respondendo às novas democracias, desenvolveria novas críticas, ideias e meios inovadores de "fazer política", assegurando deste modo que as feministas que trabalham nos partidos e no governo permaneçam honestas e responsáveis perante o eleitorado de um movimento. Uma estratégia sugerida impunha questionar, criticar e observar cuidadosa e incansavelmente os "manipuladores". Ao mesmo tempo, elas continuariam a incentivar a consciência feminista entre mulheres de todos os setores sociais, a adiantar-se à cooptação por movimentos, partidos e instituições masculinos[...]. (STERNBACH; NAVARRO-ARANGUREN; CHUCHRYK; ALVAREZ, 1994, p. 286).

Esse impasse também se materializou em fala de participante na pesquisa de campo. Ao emitir sua opinião sobre a questão do aborto a outra participante da pesquisa, disse: "Então, o que ela está falando é o que eu entendo sobre os feminismos, mesmo eu não me considerando uma feminista". Ao ser questionada sobre o porquê de sua afirmação, a participante prossegue: "Porque eu não... Então, o que está em discussão é o direito ao corpo, que a mulher não tem", omitindo sua justificativa. Talvez sua hesitação em verbalizar sobre não ser feminista possua alguma relação com essas possíveis interpretações do que significa ser feminista, ou do que se classifica como pauta feminista, como ter ou não filiação em movimento social, como já colocado nos Encontros Feministas, ou ainda, guardar alguma relação com o fenômeno da demonização dos feminismos, que será explorado no capítulo 5 da tese.

${ }^{37}$ Mulata é um termo de manifestação da subrepresentação da mulher negra, reduzida a ícone do espaço doméstico e em objetificação sexual e de dissimulação. Trata-se, portanto, de expressão linguística que traduz como a interseccionalidade de classe, raça e gênero podem estruturar as desigualdades e serem representadas por palavras que acabam por se naturalizar e corresponder à designação da raça. "A representação das mulheres pardas ou 'mulatas' como símbolo sexual faz parte de uma iconografia festejada dentro de uma concepção de nação brasileira miscigenada" (CANDIDO; FERES JUNIOR, 2019, p. 1). 
O Encontro de San Bernardo, na Argentina, ocorrido em 1990, teve como tema central "O Feminismo como um Movimento Transformacional: Avaliação e Perspectivas na América Latina" e comemorou os dez anos de realização desses eventos feministas. Houve momentos de apresentação de trabalhos e dentro da proposta maior foram propostos debates relativos à "[...] construção de identidades coletivas e valores conflitantes; variantes organizacionais e espaços de desenvolvimento; relações entre feminismo e outras áreas sociais; e propostas, perspectivas e estratégias políticas". Sternbach, Navarro-Aranguren, Chuchryk e Alvarez (1994) destacam também os avanços alcançados em termos de organização e financiamento dos Encontros, além das redes de parcerias e aproximações com setores como a imprensa feminista alternativa, escritoras, o grupo Católicas pelo Direito de Decidir, a Rede de Violência Doméstica do Cone Sul e com as mulheres integrantes do DAWN (Desenvolvimentos Alternativos para Mulheres no Novo Amanhecer).

Sternbach, Navarro-Aranguren, Chuchryk e Alvarez (1994) entendem que esses movimentos possuem dois eixos: "a relação entre feminismo e a luta revolucionária por justiça, e a relação entre o que era um movimento feminista predominantemente de classe média e os crescentes movimentos de mulheres de base popular”. As mesmas autoras atestam que isso não impediu o crescimento dos Feminismos latino-americanos. É graças a uma heterogeneidade em sua composição que o movimento é política e socialmente comprometido com "a justiça socioeconômica e o fortalecimento popular". Ainda com todos os embates, observa-se no Chile, e em outros lugares, uma interação e apoio entre os movimentos de mulheres e os movimentos feministas, como na campanha de legalização do aborto na Argentina, que contou com um comitê formado por mulheres feministas e de movimentos de mulheres, no ano de 1990.

Diante desses exemplos de ação coletiva, como ponderam Sternbach; NavarroAranguren; Chuchryk; Alvarez, (1994), entendem que o maior desafio dos Feminismos da América Latina é o de gerir as demandas dos movimentos de mulheres, [...] em favor da construção de um projeto feminista transformacional mais inclusivo, com consciência racial e de classe". Ao lado disso, as autoras compreendem que as ativistas feministas se conscientizaram que é preciso resistir e lutar pela igualdade sexual numa ampla variedade de contextos, pois os contextos de crise e repressão criaram condições para a mobilização de mulheres pobres, da classe operária e de variadas etnias. Tais condições compõem o repertório que move as mulheres a se embrenharem, dentre outras demandas não menos importantes, nas lutas pelos direitos assistenciais e creches públicas. 
E é nessa latente situação de desigualdades sociais e econômicas da América Latina que as creches estão inseridas. O trabalho "Política pequena" para as crianças pequenas? Experiências e desafios no atendimento às crianças de 0 a 3 anos na América Latina da professora catarinense Roselane Fátima Campos (2012), ao focar as creches nos países da América Latina, discutem como os acordos econômicos afetam as políticas de educação das crianças pequenas, num contexto que caminha ao lado do reconhecimento dos direitos das crianças, e como são recentes as reflexões sobre contextos, o que explica a ausência do tema nos Encontros Feministas. A análise de Campos (2011) descortina e aprofunda o panorama de focalização da educação nos segmentos vulneráveis da população, reatualizando práticas de assistência e de educação compensatória, o que guarda relação com os critérios de seleção para que as crianças acessem as vagas das creches, como apresentado em capítulo anterior. Esse olhar compensatório vem permeando o sentido da Educação Infantil brasileira, e também dos países vizinhos, trazendo, nas palavras de Campos (2012, p.83), “[...] novos dispositivos de controle social sobre as crianças e suas famílias".

Ao lado disso, observa-se um novo fenômeno relacionado às infâncias e aos critérios adotados para o ingresso nas creches, como apontado anteriormente nesse texto. Campos (2012, p.82) argumenta que a centralidade da infância no século XXI se compõe em dupla condição: "por um lado, a visibilidade das crianças e de suas misérias e, por outro, invisibilidade das condições econômico-sociais que as produzem". Para além de uma dinâmica discursiva das diferentes concepções de infância, é uma expressão perversa de "repolitização da pobreza" ao passo que se dissipam as condições estruturais que a produz, e suas diferentes manifestações.

É, pois, negando a organicidade entre as relações econômicas e políticas que governantes e organismos multilaterais atuantes na região podem anunciar a emergência de um fenômeno de tipo novo: a "infantilização da pobreza" (CEPAL, 2010). Neste contexto, a infância, a criança e sua educação adquirem um sentido de urgência e um caráter estratégico, posto considerarse que educar desde cedo é o meio mais eficaz para romper com o chamado "ciclo geracional da pobreza". (CAMPOS, 2012, p.82).

A “infantilização da pobreza", é mencionada em documentos dos organismos multilaterais que atuam na América Latina (UNESCO, UNICEF, Banco Mundial, CEPAL Comissão Econômica para a América Latina e o Caribe), e necessita ser "compreendida como decorrência do ajuste estrutural adotado pelos países da região nas décadas de 1980 e 1990". Tais ajustes se relacionam às indicações do Consenso de Washington, produzindo uma “[...] 
intensificação sem precedentes da exclusão social e da pobreza", que culminaram, nas palavras da autora, em um "holocausto social". Pressionados pelas condições impostas pelos países desenvolvidos, toda a América Latina se viu obrigada a adotar, programas e ajustes, conforme afirma Campos:

[...] fortes programas de ajustes fiscais considerados essenciais à criação dos superávits necessários ao pagamento da dívida externa, cortando, em consequência, substancialmente os recursos destinados às políticas sociais. Esses programas, associados a aspectos estruturais decorrentes da própria crise do processo acumulativo vigente, produziram massas de desempregados e subempregados, jogando milhares de trabalhadores em situação de miséria ou pobreza absoluta (CAMPOS, 2012, p.83).

Diante desse fracasso, Campos (2012) nos revela que uma segunda onda de reformas ocorreu, dessa vez, utilizando o argumento de uma revalorização social, como a defesa de redução da pobreza, promoção de equidade social e fortalecimento das democracias e dos direitos humanos, evocando diretamente as crianças.

Começa-se a falar da pobreza como "uma nova questão social" e, mais recentemente, da "infantilização da pobreza" como fenômenos novos, marcados por três traços essenciais: a) são massivos; b) atingem amplos setores da população; c) tendem a se tornar crônicos, especialmente entre os grupos sociais que vivem em pobreza extrema, ganhando nova visibilidade social, especialmente nos espaços urbanos. (SERNA, 2010 apud CAMPOS, 2012, p.84).

Conforme Campos (2012), a CEPAL (Comissão Econômica para a América Latina e o Caribe) considera a pobreza como uma situação multidimensional, multifacetada e heterogênea, geradora de um novo paradigma que deve considerar tanto a privação de renda, quanto o acesso aos direitos básicos. A esse respeito, a CEPAL entende que:

A articulação das múltiplas dimensões da pobreza com as particularidades individuais e coletivas ajuda a captar a heterogeneidade dos pobres, produto, por exemplo, de desigualdades de gênero, etnia e idade. Na região, uma parte significativa das crianças e adolescentes enfrenta adversidades que os prejudicam nesta fase do seu ciclo de vida, eles os afetarão pelo resto de suas vidas e serão transmitidos às gerações subsequentes. (CEPAL/UNICEF, 2010a, p. 4, apud Campos, 2012, p.84-85).

Partindo dessa premissa, a CEPAL faz um levantamento que informa que em 2007, 29,2\% (cerca de 59,2 milhões) de crianças latino-americanas se encontravam em situação de 
extrema pobreza, o que é considerado violação de seus direitos básicos. Outros 28, 3 milhões convivem em situação familiar com uma renda mínima, o que o organismo internacional concebe como situação de privação de direitos, e outros 31 milhões de crianças vivem em situação de pobreza monetária, mas possuem seus direitos básicos atendidos. A CEPAL também detalha, a partir de apontamentos no texto de Campos, (2012) que:

Das crianças que vivem em situação de "pobreza extrema" $(29,2 \%)$, em torno de $43 \%$ pertence a "famílias indigentes", situação que atinge, sobretudo, as crianças indígenas e afrodescendentes. Enfim, se desprezarmos as estratificações considerando que nos subgrupos mencionados todas as crianças são pobres, chegamos à perversa cifra de 105,3 milhões $(62,8 \%)$, ou seja, teríamos aproximadamente apenas $37 \%$ das crianças da região vivendo em condições adequadas. (CEPAL/UNICEF, 2010a, apud CAMPOS, 2012, p.85).

A leitura de Campos (2012) sobre a mensuração da pobreza realizada pela CEPAL é a de que ela deixa em evidência muitas lacunas. A autora pondera que tal visão - cujo critério principal de tabulação é a situação financeira que considera "1 dólar por dia" - não avança na interpretação da pobreza. Não considera suas causas e nem propõe medidas necessárias ao seu efetivo combate. Campos (2012) acrescenta, ainda, que a leitura da pobreza baseada em cifras como uma questão meramente técnica tem o objetivo de tornar eficientes as políticas sociais focalizadas, "[...] na medida em que o conhecimento das dimensões afetadas pode ser objeto de ações diferenciadas e específicas, gerando uma "nova gramática" da pobreza e uma "nova economia" nas políticas sociais" (CAMPOS, 2012, p.85). Aprofundando sua análise, Campos (2012, p.86) observa que, nessa visão de pobreza, a educação ganha destaque "[...]tanto por ser considerada como necessária a formação do "capital humano" demandado pelo desenvolvimento produtivo da região, como também por ser considerada "chave para a equidade", posto que o acesso às "oportunidades" sociais dependeria também do nível educativo das pessoas".

Subordinando-se ao capitalismo, a América Latina - tida como periferia- sofre com o obscurecimento das "relações fundamentais que estão na base do valor do trabalho, o que é providencial num continente em que predomina o subemprego e a informalidade" (CAMPOS, 2012, p.87). Deste modo, perduram-se as desigualdades sociais, no que perversamente os organismos internacionais interferem com o intuito de "aliviar" a pobreza, estabelecendo índices de estabilização econômica a serem atingidos sem que, para isso, sejam necessários investimentos efetivos à superação das desigualdades sociais. Ou seja, esse olhar não promove concretamente a justiça social, gerando implicações referentes a uma cidadania 
incompleta, pois se crianças seguem não dispondo de vagas suficientes em creches, os seus direitos à Educação ficam comprometidos, assim como os direitos das mulheres também.

A falta de creche impacta a vida das mulheres-mães, em um ciclo de desrespeito à concretização de sua cidadania, numa perpetuação de conhecidas barreiras. Conforme dados divulgados no estudo Retratos das desigualdades no Brasil $^{38}$, divulgado pelo Instituto de Pesquisa Econômica Aplicada (IPEA), a ocupação das mulheres com a responsabilidade com os cuidados com suas famílias ainda é o fator que mais se reflete nos índices de participação delas no mercado de trabalho, em fenômeno de amplitude que Jane Felipe e Cristiano da Rosa denominam, no artigo Uma Diva Dentro de Mim: descobertas femininas sobre scripts de gênero no processo de montação drag queen (2019), como as oitavas jornadas de trabalho das mulheres.

São as mulheres e meninas as principais pessoas a se ocuparem da vasta gama de tarefas no âmbito doméstico, em regime de acumulação com o cuidado com as crianças, com o corpo, com as relações, preparo de alimentos e outras incumbências (ROSA; FELIPE, 2019), perfazendo uma diferença de 7 horas e meia a mais de dedicação, quando comparadas aos homens, de acordo com o estudo do IPEA. Nas duas últimas décadas, o mesmo estudo revela que o percentual de mulheres que estão empregadas oscila em torno dos $55 \%$, nunca ultrapassando os $60 \%$.

Isso equivale a dizer, baseado na pesquisa do IPEA, que quase metade das mulheres brasileiras não estão no mercado de trabalho formal. Tal fato não incide sobre os homens, que apresentam taxas de participação de $85 \%$ no mercado de trabalho, além do fato de os homens brancos ocuparem o topo da pirâmide, em termos de participação no mercado trabalho. As participantes da pesquisa de campo se mostraram curiosas ao fato de não existir discussões sobre a estabilidade do homem após o nascimento de sua criança, ao que observaram: "verdade, ninguém nem fala...". Isso é um indicador do quanto ainda estamos distantes de conceber a maternagem como tarefa de todas as pessoas, e também do pai.

A base dessa desigualdade é composta por mulheres negras, diagnóstico feito pelo cruzamento de indicadores como a raça, o sexo, a escolaridade, a renda, a taxa de desocupação e o uso do tempo, que se somam como agravantes às oitavas jornadas de trabalho. Além de não possuírem renda, elemento que as colocam como a maior parte de

\footnotetext{
${ }^{38}$ Fonte: https://www.ipea.gov.br/portal/images/stories/PDFs/170306_retrato_das_desigualdades_de_genero_ra ca.pdf. Acesso em 02/02/2021.
} 
beneficiárias dos programas sociais do governo ${ }^{39}$, as mulheres ainda têm de enfrentar as desiguais cobranças que estão ligadas à idealização da maternidade (BADINTER, 1985) em construções que exigem atributos correspondentes aos de super-heroínas (BURMAN, 2009), penalizando socialmente como "mães más" aquelas que não correspondem a esse suposto ideal.

Ao lado desse contexto social e econômico, a ênfase na atenção à Educação Infantil na América Latina na década de 1990 se deu a partir do compromisso global com a Conferência "Educação para Todos", realizada em Jomtien no ano de 1990. Contudo, Campos (2012) nos alerta que, mesmo ocorrendo um lapso de 20 anos desde esse compromisso, pouco se observou em termos de adequação nas metas acordadas na citada Conferência, ilustradas nos seguintes percentuais.

De acordo com a UNESCO (2010b), na América Latina a taxa bruta de escolarização das crianças entre 3 e 5 anos passou de $56 \%$ a $65 \%$ no período de 1999 a 2007; entre 2002 e 2008, o crescimento foi da ordem de $2 \%$ ao ano. Esses percentuais ocultam, no entanto, profundas disparidades tanto intra como inter países, assim como dos segmentos etários atendidos. Considerando apenas a idade de 5 anos, obrigatória em boa parte dos países da região, a cobertura dessa faixa etária vai desde a universalização Argentina (95,8\%), Uruguai $(97,3 \%)$ e Chile $(92,56 \%)$, até países em que o acesso ainda é bastante restrito - Guatemala $(35,4 \%)$, Honduras $(47,1 \%)$, Equador (56,6\%) (CAMPOS, 2012, p.87).

Conforme o estudo de Campos (2012), os percentuais nacionais têm diferenças acentuadas, quando enfocados os indicadores de renda e matrículas.

[...] no Uruguai, na idade de 3 anos, $40 \%$ de matrículas situam-se no quintil mais baixo, e $92,7 \%$, no mais elevado; na idade de 4 anos: $81,5 \%$ e $97,6 \%$; e 5 anos: $95,9 \%$ e $99 \%$, respectivamente. No Brasil, apenas $66,8 \%$ das crianças de 4 e 5 anos de idade, cujas famílias têm renda per capita de até um quarto de salário mínimo, estavam matriculadas em alguma instituição educativa; já para aquelas pertencentes a famílias de renda per capita acima de um salário mínimo, esse percentual sobe para 86,9\% (IBGE, 2010b); ou seja, as crianças pertencentes aos $20 \%$ mais pobre da população são aquelas que menos acesso têm à educação (CAMPOS, 2012, p.88).

No Brasil, os dados do IBGE acessados pela autora informam que as matrículas de crianças com idade entre 4 e 6 anos, faixa etária já obrigatória, também são desproporcionais: Goiás (58\%), Rio Grande do Sul (50,1\%), Amapá e Acre (51,5\% e 51\%), Piauí e Ceará

\footnotetext{
${ }^{39}$ Fonte: http://www.onumulheres.org.br/noticias/mulheres-brasileiras-sao-maiores-beneficiarias-deprogramas-sociais-destaca-nova-publicacao-da-onu-mulheres-e-do-governo-brasileiro/. Acesso em 20/02/2021.
} 
(90,7\%) e Rio Grande do Norte (83,8\%) (CAMPOS, p.89). Já sobre o atendimento das crianças de 0 a 3 anos, poucas são as informações encontradas sobre a América Latina, à exceção do Brasil, que dispõe dos seguintes números: no ano de 2009, aproximadamente 18\% das crianças de 0 a 3 anos frequentaram algum tipo de creche. Já no Chile, o documento Educación parvularia y equidad: antecedentes diagnósticos para la política pública disponibilizou dados do ano de 2003, constando que apenas 6,2\% das crianças com menos de 2 anos de idade frequentavam alguma instituição educativa. Na Argentina, para a idade de 3 anos, observa-se que $36,6 \%$ das crianças menores de 4 anos estavam matriculadas, ao lado do percentual de $76,5 \%$ da faixa etária seguinte. Desse montante, $85,4 \%$ das crianças pertenciam às camadas médias e altas, e 35,4\%, aos segmentos mais pobres da população. No Uruguai, país com os melhores indicadores de desenvolvimento humano da América Latina, conta com “[...] 13,1\% das crianças de 0 a 2 anos são atendidas, crescendo esse percentual quando se trata das crianças de 3 anos $-48 \%$. O crescimento nas taxas de matrículas pode ser atribuído à adoção da obrigatoriedade nas idades finais dessa etapa educativa" (CAMPOS, 2012), o que se relaciona também os menores percentuais de atendimento aos bebês.

Sobre a instituição da obrigatoriedade, a América Latina é o continente que mais a tem estipulado: dos 17 países que a compõe, 14 já a implementaram, quase todos na metade dos anos 2000, a exceção do Peru, que teve tal regulamentação no ano de 2003. Campos (2012) assinala que a instituição da obrigatoriedade na citada década explica o aumento de matrículas no grupo de crianças de 5 anos.

Outra questão destacada por Campos (2012, p.90), agora na dimensão da gestão e organização, são os termos de identificação das crianças pequenas: "“educación parvulari', 'educación inicial', 'educación de la primera infancia', 'educación preescolar', 'educación preprimaria', 'educação infantil'”. De modo geral, concebe-se que a Educação Infantil “[...] se estenda do período do nascimento até os 5 anos; há países como a Venezuela que incluem o período pré-natal”. É comum a todos os países da América Latina a organização da educação das crianças pequenas em dois segmentos ou ciclos: 0 a 3 (ou 2 anos) e 4 (ou 3 anos) a 5 anos. Campos (2012) também observa que há:

[...] uma flexibilização pode atingir desde as jornadas (integral, parcial, "estendida") até o modo de organização dos espaços institucionalmente dedicados ao atendimento educativo: jardins de infância (espaços regulares e institucionalizados), "guarderías" (com fraco componente educativo), salas itinerantes (para populações afastadas dos centros urbanos), salas mistas, brinquedotecas, professores visitantes (visitas domiciliares para populações indígenas e campesinas) e educação das famílias (atividades com crianças e 
orientação às famílias, podendo ocorrer em centros comunitários ou por visitas familiares). Além dessas, encontramos também estratégias específicas para atender a populações indígenas e outras populações cujas atividades laborais são marcadas pela sazonalidade. Essas configurações dos sistemas educativos expressam e, ao mesmo tempo, instituem modos particulares de representação da infância e de sua educação (CAMPOS,2012, p.91-92).

Aprofundando mais sobre as representações de infância e também da educação, os estudos de Campos (2012) revelam que os países com maiores taxas de pobreza - e que reajustaram a Educação - têm grande aproximação com as orientações das indicações e orientações técnicas dos organismos internacionais, como a UNESCO, CEPAL e UNICEF. Essas orientações concebem a educação da primeira infância atrelada ao "sucesso escolar e, portanto, do desenvolvimento do capital humano futuro". Além disso, os documentos difundem o entendimento de que "quanto mais cedo se educa a criança, mais "oportunidades" de desenvolvimento psicofísico-social ela terá, evitando-se assim que privações se transformem em futura situação de iniquidade social. Educar torna-se assim a principal estratégia para combater a pobreza" (CAMPOS, 2012, p.92). Essa "preocupação" tem se mostrado como forte base do pensamento político de países que tornam a educação préescolar obrigatória, o que apaga a compreensão da Educação como um direito de todas as pessoas.

Sobre os programas de transferência condicionada de renda, Campos (2012, p.93) analisa que tais ações "[...] tendem a fomentar ou, muitas vezes, exigir a participação das famílias e das crianças em atividades relacionadas à educação, saúde, nutrição, cujo objetivo seria melhorar as condições de vida da chamada "primeira infância"”. Ainda que compreendida como direito das crianças, a Educação Infantil passa a se orientar em duas lógicas distintas: "políticas universalizadas para um grupo (4 a 5 anos) e políticas focalizadas e compensatórias para 0 a 3 anos", que se dividem dos seguintes modos, todos financiados por organismos internacionais, conforme apresentados nos estudos de Campos (2012):

[...] a programas desenvolvidos em centros de educação infantil que oferecem atendimento diário em período parcial ou integral, que contam com profissionais formados e voluntários; podem ser abrigados em instalações públicas ou cedidas pela comunidade. Boa parte dos programas situados nessa categoria são executados por organizações sociais. Podem ter um caráter menos de "atenção" e mais de preparação para a escola; $b \mid$ programas de atendimento direto, de caráter socioeducativo, oferecidos em espaços comunitários, realizados por pessoas da própria comunidade, que recebem orientações (treinamento) de equipes de coordenação para o desenvolvimento de atividades de saúde, nutrição e educação. Podem ter frequência diária, com jornadas estendidas, observando sazonalidade 
(períodos do ano e espaços) dos grupos atendidos. Dependem de elevado envolvimento da comunidade; c| programas desenvolvidos em espaços comunitários ou em centros próprios destinados à atenção socioeducativa de crianças pequenas, orientados pela concepção de estimulação do desenvolvimento. Articulam orientação familiar, especialmente às mães, com atendimento direto às crianças, pelo menos uma ou duas vezes na semana. O foco é o fortalecimento da relação entre a família e a criança. Estes programas também podem ser itinerantes (o educador comunitário vai à casa da família); $\mathrm{d}$ | programas de caráter socioeducativo dirigidos às famílias; não implicam atendimento direto às crianças, mas seu alvo são as famílias que recebem orientações sobre como estimular o desenvolvimento de suas crianças. É desenvolvido por meio de visita domiciliar (CAMPOS, 2012, p.94).

Outros elementos, também, podem se associar a esses programas, como a iniciativa das classes itinerantes ou "jardins sob rodas", existentes na Argentina, as brinquedotecas na Venezuela, os programas televisivos e programas voltados para grupos específicos (mães adolescentes; mães em privação de liberdade) no Chile. Tais iniciativas também podem ser modificadas, segundo Campos (2012, p.94), em função dos grupos étnicos - casos da Bolívia, do Equador e do Peru -, considerando "[...] as referências culturais que orientam as relações educativas entre família e crianças, e comunidade e crianças, ou da localização - regiões rurais ou mais afastadas dos grandes centros urbanos". Eles têm o caráter de estimulação precoce e de promoção de cuidados infantis. Campos (2012) assevera que a dinâmica desses programas denota o controle social, pois:

Essas estratégias, que combinam intervenções e disciplinamento dos "modos de vida" das famílias, visam a disseminar "conhecimentos científicos" sobre o desenvolvimento das crianças e estratégias pedagógicas de cuidado: livretos, materiais para uso com as crianças, difusão em mídias, são alguns recursos utilizados para isso. (CAMPOS, 2012, p.96).

Explicitadas as bases que os programas sociais atuam, Campos (2012, p.96) compreende que as ações se voltam à educação das famílias "no sentido de habilitá-las, qualificá-las para a educação das crianças pequenas, e já naquelas em idade pré-escolar se estimula o desenvolvimento de competências preparatórias para o desempenho escolar futuro". Nesse sentido, a autora compreende que duas dimensões dialogam: a da atenção e a educação, observando que o primeiro componente sobressai-se ao segundo. Ao reproduzir tal concepção, os programas sociais contribuem para que se perpetue o entendimento de que "[...] a atenção é fundamentalmente tarefa das famílias", dissimulando o papel do poder público, relativizando o significado simbólico da educação com centralidade no desenvolvimento 
físico e na dimensão cultural. Tal entendimento é recorrente nas falas das participantes da pesquisa de campo, categóricas em afirmar, em diversos temas que "isso tem que vir de casa".

Acrescentamos que essa concepção se choca profundamente com a dimensão dos direitos, constituindo um desrespeito. A própria UNESCO "tem tomado também essa concepção na orientação de seus programas, o que pode ajudar a compreender a crescente hegemonia da tríade conceitual: 'atenção integral', 'equidade' e 'vulnerabilidade social'”. Campos (2012, p.98) expõe que "[...] dada a condição de pobreza da região, em alguns casos, é necessário que as crianças recebam atenção extrafamiliar”, mesmo porque é também função do Estado gerar condições para que os direitos básicos das crianças sejam respeitados.

É nesse panorama que Campos (2012) conclui que desde a década de 1980 já se anunciava que a pobreza era 'pobremente' tratada. Essa afirmação se baseia na "persistência em tratar a educação das crianças pequenas como estratégia para mitigar a miséria", sendo tal postura responsável por criar “[...] novas formas de segmentação e de focalização de políticas, que, longe de distribuir com "equidade" as "oportunidades educacionais", criam novas formas de discriminação e de subalternização". Sobre o currículo, Campos (2012) atesta que:

Isso se reflete também nas orientações curriculares: para as primeiras, o
preparo para a escola, visto que os principais argumentos para a
obrigatoriedade são os impactos positivos da pré-escola nas trajetórias
escolares futuras. Para as segundas, a oferta de programas dirigidos à
educação das famílias "que vivem em situação de pobreza ou de extrema
pobreza" - para que estas, devidamente instruídas, se encarreguem de
desenvolver boas "práticas de criação", além de atividades lúdicas e
estimulantes. (CAMPOS, 2012, p.99).

Ainda sobre os efeitos dos programas sociais destinados à pequena infância na América Latina, Campos (2012) adverte que boa parte das mulheres aos quais as ações dos programas se direcionam são trabalhadoras, "[...] quase sempre exercendo atividades laborais fora do lar e, muito frequentemente, com baixos níveis de escolaridade, além de reafirmarem a "privatização do cuidado" sob a responsabilidade das mulheres." (CAMPOS, 2012, p.99). Ainda que todos os sistemas de ensino da América Latina tenham incorporado o direito das crianças pequenas à educação, Campos (2012) observa que em muitos países a educação das crianças de 0 a 3 anos se inclui em uma modalidade "não escolarizada", provida por organizações sociais de natureza privada, que atuam sob a chancela do poder público "prestando esse serviço" para as comunidades, o que denota diversos tipos de arranjo institucional e de dispositivo de regulação envolvendo a esfera pública e a privada, mas com pouco controle estatal efetivo sobre esses arranjos. 
As orientações dos organismos internacionais multilaterais, "promotores e árduos defensores de políticas compensatórias para as crianças pobres" (CAMPOS, 2012, p.100) tendem a articular argumentos em torno de demandas advindas de pressões sociais, o que ganha espaço principalmente em países cujos governos vêm desencadeando reformas estruturais de base. $\mathrm{O}$ acesso à creche continua muito restrito, se considerarmos o percentual apresentado por Campos (2012) no qual no Brasil apenas $18,4 \%$ de crianças frequentando a creche no ano de 2009. É uma discrepância considerável quando esse número é comparado às metas do Plano Nacional de Educação de 2001, que estabeleceu a meta de 30\% para o ano de 2006 e de $50 \%$ até o ano de 2010.

Entre os anos de 1999 e 2009, ainda segundo dados do IBGE acessados por Campos (2012), houve um crescimento de 10,8\% nas matrículas em creche, ao passo que a pré-escola, nesse mesmo período, contou com um crescimento de matrículas em torno de 27,8\%. Também na creche encontramos as taxas mais elevadas de atendimento em instituições privadas. Focando na renda familiar, dados do ano de 2009 revelam que apenas 11\% das crianças pertencentes ao quinto mais pobre da população estava matriculada em creches, contra $34,9 \%$ das crianças do quinto mais rico. Esses números revelam as desigualdades sociais e regionais aos quais as infâncias são significativamente afetadas, já que $70 \%$ das crianças de 0 a 6 anos pertencem a famílias com renda per capita de até um salário mínimo, portanto, aquelas mais atingidas pela pobreza (CAMPOS, 2012, p.102).

Sobre a unidade pedagógica prevista na Lei de Diretrizes e Bases da Educação Nacional (LDBEN), entre creches e pré-escolas, Campos (2012) compreende que a obrigatoriedade da pré-escola "tende a modelá-la e aproximá-la da norma pedagógica da escola", ao mesmo tempo em que:

[...] a oferta pública da educação para esse segmento etário, devido à priorização dos governos em atender ao preceito constitucional, pode levar a uma ampliação na transferência da "prestação do serviço" educativo das crianças de 0 a 3 anos para instituições privadas conveniadas. Essa estratégia é crescentemente adotada pelos municípios que, premidos pelo Ministério Público e pressões sociais, priorizam atender ao nível obrigatório (CAMPOS, 2012, p. 100-101).

Comparando a realidade brasileira com as que aqui foram citadas em contexto latinoamericano, Campos (2012) aponta que o Brasil se distingue "pela institucionalização da unidade pedagógica da educação infantil: creche e pré-escola são consideradas a primeira etapa da educação básica, a que antecede o período escolar”. Contudo, a mesma autora 
informa que, referentes às creches, "carecemos de estudos que revelem a real situação sobre as relações entre a esfera pública e a privada", mesmo porque, diante da obrigatoriedade, a demanda por vagas tem levado muitos municípios a diminuir o número de vagas para as crianças de 0 a 3 anos nas instituições públicas, reorientando sua ação para a ampliação dos convênios. Campos (2012) relembra que as orientações do FUNDEB sinalizam a essa direção, pois não preveem medidas de transição ou mesmo alguma objeção institucional ou temporal para os convênios em creches, o que explica a atuação de ONGs na Educação Infantil. O que era uma alternativa até a década de 1980 passou a ser forte prestação de serviços, o que Campos (2012) aponta como "setor público não estatal". Desta maneira, a Educação é vista como “"serviço” e não como direito social básico" (CAMPOS, 2012, p. 101), tornando prejudicada a noção de cidadania das crianças e das mulheres, público que acessa as creches e escolas de Educação Infantil.

Desse panorama latino, passamos a conhecer como os países europeus concorrem em políticas de atenção às infâncias e como tais políticas afetam a cidadania destas e das mulheres.

\subsection{UM GIRO PELA EUROPA: EDUCAÇÃO E ATENÇÃO ÀS CRIANÇAS PEQUENAS}

O documento Primeira infância e emancipação das mulheres: para a refundação do serviço público, redigido pelas ativistas feministas Anne Bucas-Français, Jacqueline PenitSoria e Nicole Savey ${ }^{40}$, da Coordenação Feminista de uma Europa Alternativa no ano de 2006, analisa que, em todos os países da União Europeia a demanda pelo cuidado de crianças pequenas pelos pais é maior do que a oferta de vagas em creches públicas. O citado texto agrupa os países conforme a oferta e os tipos de oferta de educação e cuidados dispensados às crianças da seguinte maneira:

Grupo 1: Países nórdicos onde as instalações públicas foram massivamente desenvolvidas. As taxas de cobertura de uma creche (assistente coletivo ou materno) são de $48 \%$ na Suécia e $64 \%$ na Dinamarca, com um tempo médio de atendimento de 8 horas (Suécia) e 10-12 horas (Dinamarca).

Grupo 2: França e Bélgica oferecem uma ampla variedade de cuidados e apoio público.

Grupo 3: Alemanha, Áustria e Holanda, onde há poucas instalações de recepção e o setor privado às vezes é bem desenvolvido; Na Alemanha, viveiros coletivos públicos ou privados recebem apenas $6 \%$ das crianças em

${ }^{40}$ O texto foi redigido com as contribuições de Ana Azaria, Françoise Claireaux, Monique Dental, Sabine Lagoutte, Françoise Maquin, Monika Karbowska, Marie-Hélène Tissot e Stéphanie Treillet. 
1994 e não há nenhum tipo de prestação de cuidados infantis. Nos Países Baixos, 3/4 da capacidade de recepção é gerida pelo setor privado. $\mathrm{Na}$ Áustria, 50\% das creches coletivas são administradas privadamente (OCDE, 2003)

Grupo 4: Reino Unido e Irlanda, em que a oferta pública é fraca e já está sendo retransmitida, principalmente, por iniciativas locais e privadas, o que permite a esses países atingir índices de cobertura de $31 \%$ e $34 \%$. Na Irlanda, as creches são geralmente privadas que recebem poucos subsídios públicos e são frequentemente comerciais (OCDE, 2003). Dos 31\% das crianças alojadas em estruturas "coletivas", 19\% são informalmente cuidadas por auxiliares de creches não registrados, que podem manter até 3 crianças sem qualquer regulamentação especial. No Reino Unido, as taxas de estruturas privadas são altas, e o Estado oferece assistência substancial às famílias mais modestas sob a forma de um crédito fiscal de trabalho.

Grupo 5: Países mediterrâneos onde as estruturas de acolhimento de crianças são escassas e a solidariedade familiar desempenha um papel importante. (BUCAS-FRANÇAIS; PENIT-SORIA; SAVEY, 2006, p. 6).

O período da década de 1970 é impulsionador de inúmeras iniciativas feministas de defesas dos direitos das mulheres, e consequentemente, de atenção às suas demandas. Essas iniciativas, para além da satisfação de necessidades exclusivas das mulheres, oportunizam a construção de uma sociedade mais democrática, pois assim, segundo Rosemberg (1990), todas as pessoas poderiam usufruir- e não só os homens - das mesmas condições, oportunidades e responsabilidades. Conforme o texto de Bucas-Français, Penit-Soria e Savey (2006), ainda persistem formulações institucionais essencialistas quanto à figura da mulher, mesmo em países como a França, considerado avançado nas políticas de atenção ${ }^{41}$ à infância.

As autoridades públicas, propondo soluções de "reconciliação" entre vida profissional e vida familiar, apenas escondem a dimensão da divisão sexual do trabalho na sociedade. Elas raramente fazem a conexão entre a necessidade de um serviço público na primeira infância e seu papel na emancipação das mulheres. As políticas atuais, a serviço do neoliberalismo, mantêm a organização patriarcal da sociedade (BUCAS-FRANÇAIS; PENIT-SORIA; SAVEY, 2006, p. 2).

Bucas-Français, Penit-Soria e Savey (2006) apontam que a expansão das creches e escolas maternais públicas na França ocorreu no período compreendido entre as décadas de 1960 e 1980, favorecendo o acesso das mulheres ao trabalho em tempo integral e auxiliando a mulher com mais de dois filhos em autonomia financeira e também em emancipação (BUCAS-FRANÇAIS; PENIT-SORIA; SAVEY, 2006, p.3). Desse panorama geral, as

${ }^{41}$ O texto de Bucas-Français, Penit-Soria e Savey (2006) utilizam o termo "atenção" quando se referem às ações políticas governamentais que subsidiam os cuidados com as infâncias. Tal termo é empregado na tese somente em referência às análises dessas autoras. 
autoras passam a analisar pormenorizadamente as opções que os países dispõem às mulheres mães de crianças pequenas, alertando que "[...] os dispositivos públicos estabelecido não são neutros. Eles revelam as representações coletivas da maternidade e funções parentais" (BUCAS-FRANÇAIS; PENIT-SORIA; SAVEY, 2006, p.5), como identificado a seguir.

Três dimensões se combinam em cada país para entender a importância dos orçamentos públicos da parte dedicada ao cuidado de crianças pequenas e à natureza dos dispositivos instalados:

-1: a importância que a ação pública dá à atividade profissional das mulheres como o motor da igualdade entre homens e mulheres

-2: a concepção "política" da família, e que implícita a maior ou menor complementaridade dos papéis sociais masculinos e femininos:

-3: a importância dada à socialização precoce da criança como elemento de luta contra os efeitos da desigualdade.

Dependendo de como esses três parâmetros são combinados, as políticas podem desempenhar um papel mais ou menos emancipador para as mulheres (BUCAS-FRANÇAIS; PENIT-SORIA; SAVEY, 2006, p.5).

Em toda a Europa, as famílias contam com três opções de cuidados com as crianças, conforme as informações disponibilizadas por Bucas-Français, Penit-Soria e Savey (2006, p.5): os modos de guarda coletiva, na forma de creches, berçários e jardins de infância, que dispõem de equipes qualificadas que prestam atendimento o dia todo em instituições públicas ou privadas; os modos individualizados, na forma de auxiliares de creche que mantêm crianças em casa, e a assistência domiciliar, em que os pais contratam pessoas para cuidar das crianças em casa, com ou sem ajuda do Estado. Até o ano de 2004, os provimentos estatais dispunham das seguintes denominações e critérios de disponibilização:

1/APJE (subsídio para crianças pequenas): benefício básico pago a qualquer família com filho a cargo menor de 3 anos de idade. Além do prêmio pago durante a gravidez, ela incluiu uma mesada mensal de recursos. Cerca de $60 \%$ das famílias com crianças com menos de 3 anos de idade receberam este subsídio em 2001, no montante de 156 euros por mês.

2/ APE (subsídio de educação dos pais): benefício pago quando um dos pais (a mãe em 98\% dos casos) cessa (ou reduz) a sua atividade profissional para criar pelo menos dois filhos (um dos quais tem menos de três anos). Em 2001 , o montante pago a taxa plena era de $485 €$ por mês e $23 \%$ das mães com um filho com menos de 3 anos beneficiaram dele.

3/ AFEAMA (Assistência à família para o emprego de um assistente maternal aprovado): é concedido para o emprego de um assistente de jardim de infância. Foi $380-400 €$ por mês. Por um lado, incluía um subsídio que variava de acordo com a renda da família e, por outro, a assunção das contribuições previdenciárias e do empregador.

4/ AGED (subsídio de puericultura). Correspondeu a um subsídio de 75\% das contribuições associadas com o salário do trabalhador doméstico que cuida da criança com um teto do salário. Em 2001, a média era de $180 €$ por 
mês. Além disso, é acompanhado de uma dedução fiscal concedida no âmbito geral das isenções fiscais concedidas para o emprego de um trabalhador domiciliário e que corresponde a $50 \%$ das despesas incorridas até ao limite de $6900 €(\mathrm{em} \mathrm{2001)}$. Este teto foi aumentado para $€ 10.000 \mathrm{em}$ 2003 (Bucas-Français; Penit-Soria; Savey; 2006, p.9).

Tal respaldo legal europeu se difere quando comparado ao quadro brasileiro. $\mathrm{O}$ salário-família ${ }^{42}$ pago às trabalhadoras/es brasileiros com filhas/os, corresponde, em valores atualizados no ano de 2020, ao valor de $\mathrm{R} \$ 48,62$ por criança, direcionado aquelas/es cujo salário não ultrapasse o valor de $\mathrm{R} \$ 1.425,56^{43}$, sem denominações de finalidade de uso desse recurso. Há também o Programa Bolsa-Família, cuja transferência de recurso é direcionada à famílias em situação de pobreza ou miserabilidade, que possuam filhas/os com idade de 0 a 17 anos. Criada em 2004, a Lei ${ }^{\circ} 10.836 / 04$, que dispõe sobre esse benefício, estabelece que sejam observadas as condições de saúde e de educação das crianças e adolescentes contempladas $^{44}$.

Outro interessante olhar sobre as dimensões da responsabilidade para com as crianças, desta vez no nível das relações familiares, é trazido pelo texto das psicólogas brasileiras Luana Pasinato e Clarisse Pereira Mosmann (2016), intitulado Transição para a parentalidade e a coparentalidade: casais que os filhos ingressaram na escola ao término da licença-maternidade. As citadas autoras discutem sobre os impactos que o duplo trabalho impõe à dinâmica familiar, realidade esta que tende a reconfigurar os modos de participação na educação das crianças e as responsabilidades familiares como um todo, ainda que se enfrentem conhecidos desafios no reconhecimento dessa tarefa, como a pouca participação dos homens.

Pasinato e Mosmann (2016) também mencionam a enorme a desigualdade das licenças parentais a que homens e mulheres acessam no Brasil: 120 dias para as mulheres, e apenas 5 para os homens. Em virtude do ano de publicação, tal texto não menciona que o Programa Empresa Cidadã (Lei 11.270, de 09 de setembro de 2008) foi alterado, prorrogando a licençapaternidade para 20 dias, para aqueles que trabalhassem em empresas que aderissem ao programa $^{45}$. Mesmo tal programa constituindo uma mudança, o tempo exíguo imposto pela

\footnotetext{
${ }^{42} \mathrm{O}$ salário-família é direito da/o trabalhadora/or brasileira/o, que trabalhe junto à empresa vinculada à Previdência Social Brasileira, proporcional ao número de filhas/os menores de 14 anos, conforme estipula a Consolidação das Leis do Trabalho, na forma da Lei no 4.266 , de 3 de outubro de 1963.

43 Fonte: https://economia.uol.com.br/guia-de-economia/salario-familia-valor-cota-baixa-rendabeneficio-inss-empregado.htm Acesso em 23/01/2021;

${ }^{44}$ Fonte: http://www.sedes.df.gov.br/bolsa-familia/ Acesso em 23/01/2021.

${ }^{45}$ Fonte: http://www.planalto.gov.br/ccivil_03/_ato2007-

2010/2008/lei/11 1770.htm\#: :text=LEI\%20N\%C2\%BA\%2011.770\%2C\%20DE\%209\%20DE\%20SE
} 
legislação trabalhista brasileira pode comprometer a apropriação da coparentalidade, elemento importante na consolidação dos processos de maternagem. Isso é um contrassenso mediado pelo Estado, já que há uma socialização discrepante no que toca à dedicação dos genitores às crianças nascidas, ou adotadas, na família. Isso se afasta da legislação, que estabelece que a Educação das crianças é responsabilidade da família, com a colaboração da sociedade, inclusive do poder público, personificado pelas ações do Estado.

Retornando ao contexto europeu, no ano de 2004, após reforma que visou simplificar os sistemas de ajuda, as famílias passaram a contar com um serviço global denominada $\mathrm{PAJE}^{46}$ (prestação de cuidados infantis) que recobriu um número maior de famílias em virtude de ajuste do teto das rendas familiares e se destinou ao acesso destas a um/a assistente maternal, de maneira individualizada. No entanto, as feministas asseveram que essa mudança não representou significativamente o acesso a essas/es profissionais pelas camadas mais modestas da população, posto que menos de $10 \%$ das famílias que possuem renda familiar na faixa dos 748 a 950 euros contratam assistentes maternais (BUCAS-FRANÇAIS; PENITSORIA; SAVEY, 2006).

Há também expressivas diferenças nas maneiras de cada país atuar nas medidas de atendimento institucional. A esse respeito, as análises das feministas Anne Bucas-Français, Jacqueline Penit-Soria e Nicole Savey (2006) apontam que a Suécia e a Dinamarca dão amplo suporte às crianças e investem muito nos serviços públicos de atendimento à infância. Já na França, ao lado de avançadas políticas de atenção, como o pagamento de abonos firmados pelo governo, existe o desprestígio e o abandono dos serviços de creches comunitárias, em detrimento dos sistemas de cuidados individuais, popularizados no início dos anos de 1980. No Brasil, como já exposto, os benefícios disponibilizados pelo governo, quando existem para tal finalidade, são destinados às famílias em condição de pobreza, com exigência de emprego regulamentado, determinação de teto salarial e de frequência à escola, como critérios de usufruto dos mesmos.

Os ganhos mais significativos dos movimentos feministas em termos de políticas de creches estão nos países escandinavos ${ }^{47}$, em que "[...] a igualdade de gênero não é apenas um valor, mas um princípio de ação" (BUCAS-FRANÇAIS; PENIT-SORIA; SAVEY, 2006, p.7). Lá se observa a maior taxa de empregabilidade das mulheres de toda a Europa, com

TEMBRO\%20DE\%202008.\&text=Cria\%20o\%20Programa\%20Empresa\%20Cidad\%C3\%A3,Art. Acesso em 23/01/2021.

${ }^{46}$ Prestation d'accueil du jeune enfant.

${ }^{47}$ A região da Escandinávia engloba a Dinamarca, Suécia, Noruega, Finlândia, Islândia e as Ilhas Ferie. 
poucas diferenças quando comparadas aos homens. Grande parcela dessas mulheres (35\%) atua em trabalhos de tempo parcial, e o modelo da dona de casa encontra-se ameaçado. Isso porque "[...] os direitos sociais dos cidadãos são individualizados, eles não dependem de gênero ou status familiar" (BUCAS-FRANÇAIS; PENIT-SORIA; SAVEY, 2006, p.8), ganho conquistado pelas mobilizações feministas naquele país, já que as questões familiares não intervém nos direitos e nas provisões de Estado. Logo, nos países escandinavos o atendimento às crianças pequenas em equipamentos coletivos é um direito legal consolidado. A regulamentação da licença parental em 15 meses, e as salvaguardas existentes para que pais e mães de crianças menores de 8 anos possam reduzir a sua carga horária diária de trabalho sem perdas financeiras são outros avanços importantes, mas as feministas atestam que esses dispositivos infelizmente não mudam as expectativas sociais com relação às figuras tradicionais da mãe e do pai, uma vez que em sua grande maioria são as mulheres que reduzem sua jornada de trabalho, ainda comumente em setores ligados ao cuidado (BUCASFRANÇAIS; PENIT-SORIA; SAVEY, 2006). Parece-nos que, tal dissonância apontada em solo europeu corresponde, assim como no Brasil, a um processo em construção da socialização igualitária de gênero, já que se caminha em meio a avanços e estagnações sociais.

$\mathrm{Na}$ Suécia, existe um sistema de ensino pré-primário a partir dos 2 anos de idade, sendo a idade de escolaridade obrigatória estabelecida aos 7 anos, com a particularidade de não ser totalmente gratuita. É somente a partir de 2003 que crianças de 4 a 5 anos podem se beneficiar desse ensino de maneira pública.

Bucas - Français, Penit-Soria e Savey (2006) atestam que, ao lado de progressos e retrocessos, nos países da Áustria e da Alemanha a família é uma instituição social tradicional e poderosa, que perpassa a relação entre o indivíduo e o Estado. Há muita rigidez por parte do Estado em conceber que somente a mulher é responsável pela socialização da criança, e que é função do homem prover financeiramente as necessidades da família. Isso resulta em políticas de alocação de auxílios pagos às mulheres grávidas, mas pouco investimento em equipamentos públicos, como creches e jardins de infância. Tal quadro colabora para a descontinuidade das atividades laborais das mulheres, que param de trabalhar quando têm filhas/os, retornando ao trabalho somente quando estas/es já cresceram. O corte etário das mulheres nessa situação está compreendido entre os 25 e 40 anos, o que contribui para que a mulher-mãe seja estigmatizada na sociedade alemã. Na Alemanha e na Áustria a instituição tradicional para crianças de 3 a 6 anos é o jardim de infância em instituição privada. 
Sobre a questão do trabalho das mulheres-mães, as participantes da pesquisa de campo relataram que tem conhecimento de reclamações por parte de pessoas cujas crianças não acessaram vaga na creche, ao contrário de outras, "que a mãe não trabalha, e conseguiu". Algumas participantes opinaram pela priorização de atendimento das crianças filhas de mães trabalhadoras, enquanto outras questionaram "Mas como vai arrumar emprego? Com o filho no colo?". Nesse momento do debate há um tensionamento dos direitos das crianças e os direitos das mulheres, precisamente no direito à Educação e o direito ao trabalho. Como opinou uma participante: "a creche é direito da criança, ela é prioridade", no que obviamente concordamos. No entanto, fica a reflexão sobre o que é necessário para que os direitos das mulheres e os direitos das crianças sejam pensados de modo relacional, de modo a evitar o impacto de uma possível sobreposição dos direitos, pois o direito à educação de uma criança cuja mãe não trabalha, ao ser preterido ao de uma criança que a mãe esteja no mercado de trabalho, constitui um desrespeito.

Ainda sobre as políticas de atendimento à infância na Europa e as realidades em cada país, Bucas-Français, Penit-Soria e Savey (2006) apontam que o Reino Unido e os países do sul da Europa não concebem a questão do cuidado com as crianças como uma obrigação do Estado. Nesses países, as mulheres lançam mão de redes de solidariedade e proximidade para lidar com essa situação. No Reino Unido, só a partir de 1997 foi atribuído financiamento público para acolher as crianças dos 3 aos 6 anos, para fazer face à pobreza crescente. Na Espanha ainda há o fator agravante de os homens não partilharem as tarefas domésticas. Existe uma "tolerância" para com as mulheres que diminuam o número de horas trabalhadas por conta dos cuidados com as crianças, prática esta que ilustra a tensão entre o público e o privado, polarizando as famílias como "modernas" (aquelas que conciliam o trabalho e o cuidado com a família) e "tradicionais" (aquelas que as mulheres atuam como donas de casa pela ausência de possibilidades de assistência à infância). Em contexto brasileiro, as participantes da pesquisa de campo destacaram que "uma mãe provém os cuidados dos seus filhos, visando sempre os cuidados de cada etapa e idade de vida para sua criança, respeitando e educando seus filhos ficará bem mais fácil para integrar uma criança a uma sociedade justa e civilizada", o que indica que os olhares conservadores sobre a maternidade - e a maternagem - não são exclusivos do continente europeu.

Em termos orçamentários, Bucas-Français, Penit-Soria e Savey (2006) reconhecem que os valores dispensados aos cuidados com a infância aumentaram, passando de 756 bilhões para 832 bilhões no período de 1993 a 2001. Isso significa uma vontade política de dispor de 
atenção às crianças. Porém, as feministas alertam que esses meios financeiros foram enormemente aplicados à modos individualizados de cuidados, pois o montante de 5000 vagas em creches públicas criadas no período de 1985 a 1996 decaiu de modo considerável, passando para apenas 1500 entre os anos de 1996 a 1999. As feministas atribuem a essa situação a descentralização da construção de creches ocorrida na década de 1980. Tornou-se importante a questão voltada aos custos dessas instituições, o que fez o Estado buscar alternativas de parcerias com os municípios. Essa transferência de responsabilidades ocasionou em muitos casos, a escassez de recursos para que as famílias fossem atendidas, pois os municípios deveriam arcar com 30\% dos custos de construção e manutenção, situação inatingível para muitas localidades. Tal política agravou a situação de desigualdade atendimento às crianças em estruturas coletivas, já que os meios urbanos são melhores equipados que as zonas rurais.

Outra nuance debatida por Bucas-Français, Penit-Soria e Savey (2006) foi o acesso à EPA e as desigualdades embutidas perversamente nesse sistema. Não se trata de uma livre escolha ou mesmo um direito o acesso a esse benefício. Além de novamente a mulher ser chamada à responsabilidade de cuidar da prole, mães que não trabalham não recebem qualquer auxílio. Só o recebe a mãe que se retirou do mercado de trabalho por ocasião do nascimento da criança. O recebimento do EPA obscureceu a situação do trabalho das mulheres, pois $30 \%$ das beneficiárias se encontram trabalhando em tempo parcial ou desempregadas. A reintegração profissional dessas mulheres passa pelas dimensões da baixa valorização (mais precisamente pelos salários inferiores dos trabalhos em tempo parcial) e também pela falta de trabalho. Ademais, como a prioridade dos lugares na creche são das mães que trabalham, as crianças filhas de pais e mães desempregadas têm o acesso dificultado a uma condição que poderia contribuir na busca por um emprego, como também debatido pelas participantes da pesquisa de campo. Essa conjuntura termina por afirmar os modos de guarda individuais, principalmente da mãe, como "[...] uma maneira de fugir de um emprego por causa das más condições de trabalho" (BUCAS- FRANÇAIS; PENIT-SORIA; SAVEY, 2006).

Aprofundando mais a análise sobre as influências advindas do neoliberalismo no cuidado e educação das crianças pequenas, Bucas-Français, Penit-Soria e Savey (2006) são contundentes em afirmar que as escolhas políticas e econômicas são também ideológicas, no que diz respeito às políticas de infância. Com relação à situação dos empregos - precarizados financeiramente em nome da flexibilização de horários, que pretensamente resolveria o 
problema do desemprego - Buca-Français, Penit-Soria e Savey atestam que os subempregos afetam mais as mulheres do que os homens, pois torna possível empregar mulheres ao mesmo passo que as retornam para o lar com o pagamento do EPA, além de reduzir as despesas com a puericultura. Tais ações são menos dispendiosas que abrir vagas nos berçários. Isso se liga à uma ideologia maternal, como se outras pessoas não pudessem se incumbir da educação das crianças, onde "podemos ver como as escolhas neoliberais e a circulação dos estereótipos femininos e masculinos, produtos da dominação patriarcal, reforçam-se mutuamente" (BucaFrançais; Penit-Soria; Savey,2006, p.17).

$\mathrm{Na}$ opinião das autoras, o descaso com os investimentos públicos em estruturas públicas voltadas às crianças é um retrocesso social significativo que afeta a autonomia das mulheres de modo geral, e de modo mais específico, as mulheres de origem humilde, pois a sociedade as abandona com a falta de vagas em creches coletivas, única alternativa para elas. Além disso, a dedução fiscal com o gasto de contratação de um/a assistente maternal beneficia apenas as famílias de classe mais alta, o que denota mais uma desigualdade. Faz parte dessa conjuntura a incursão de empresas privadas no provimento de creches, inclusive contando com o apoio financeiro do Estado, no que consiste em medida descabida no suprimento de setor de área fundamental e de responsabilidade das políticas de caráter público (BUCAFRANÇAIS; PENIT-SORIA; SAVEY, 2006), posturas criticadas também em contexto brasileiro. Anteriormente, as creches privadas na França funcionavam com a participação da administração pública ou de maneira independente. Com o avanço nos acordos econômicos, a preocupação maior é com a vulnerabilidade da escola maternal na Europa, já que além de não ser obrigatória, não é autônoma na sua existência e manutenção.

As feministas denunciam que são raras as menções sobre os jardins de infância na França, alertando sobre o possível desaparecimento gradual das escolas maternais na França. As tendências assumidas pelas políticas de governo vêm se afinando com as recomendações da $\mathrm{OCDE}^{48}$, cujas elaborações voltadas ao desenvolvimento sustentável social e econômico indicam que "por exemplo, créditos operacionais podem ser reduzidos a escolas ou universidades". O temor dessas estudiosas é o do uso perverso dos dados de pouca frequência em creches por conta dos modos de cuidado individual incentivados pelos auxílios à educação. Esses dados não correspondem à totalidade da situação de crianças atendidas: há locais que as creches têm baixa adesão, ao lado de instituições que acolhem um grande número de crianças. Esses números não recobrem todas as situações que interferem no acesso

\footnotetext{
${ }^{48}$ Organização de Cooperação e de Desenvolvimento Econômico.
} 
aos berçários e jardins de infância, como a concorrência com creches privadas, o baixo número de instituições públicas ou a oferta (ou inexistência) de outras opções de cuidado. Medidas de ajustamento, como a supressão de classes baseados em argumentos superficiais ou de benefício individual podem impactar a contratação de professoras/es, desmerecer as especificidades da educação das crianças pequenas e imprimir mais uma desigualdade de recursos e equipamentos à população pobre, que deixa de contar com a gratuidade das creches públicas.

Tal contexto vai em sentido contrário à emancipação das mulheres também, que dependem dessas instituições para a manutenção de sua vida profissional (BUCAFRANÇAIS; PENIT-SORIA; SAVEY, 2006). O equipamento dos jardins de infância é tão significativo para a autonomia das mulheres que, em termos numéricos disponibilizados pelas feministas, a taxa de crianças matriculadas em jardins de infância na década de 1960 era de 36 $\%$, mantendo-se proporcional ao montante de mulheres que retornavam ao mercado de trabalho após a maternidade (42\%). Com o aumento dos investimentos nesse setor se nota que no ano de 2003, 80\% das mulheres mães exercem atividades profissionais, resultado do acesso em $100 \%$ de crianças com idade entre 3 e 6 anos aos jardins de infância. Essa relação foi apontada também em contexto brasileiro, na pesquisa de Doutorado da economista brasileira Viviane Sanfelice. A economista atesta que a redução em 10 pontos percentuais no número de crianças aguardando vaga em creches na grande São Paulo impactaria a taxa de emprego das mulheres-mães em 1, 2 ponto percentual, em efeitos diretos na redução da pobreza $^{49}$.

Ainda com relação ao trabalho, Bucas-Français, Penit-Soria e Savey (2006) detalham que essa continuidade na vida profissional se deve à popularização dos empregos em tempo parcial. O trabalho em meio-expediente não corresponde a um melhor gerenciamento das vidas profissionais e familiares, já que dados acessados pelas autoras informam que $45 \%$ das mulheres prefeririam trabalhar em período integral, se existissem mais e melhores possibilidades de atendimento à infância. Outra questão apontada por mulheres europeias é que não são permitidas negociações nos horários de trabalho, imposições estas que interferem no tempo do cuidado das crianças depois da escola. Esse contexto desigual afeta principalmente as mulheres imigrantes, que representam $37 \%$ do total de empregos em tempo parcial, e também mulheres em situação monoparental.

\footnotetext{
${ }^{49}$ Fonte: https://www.valor.com.br/brasil/6062547/creche-publica-eleva-em-44-pontos-probabilidadede-mae-trabalhar. Divulgado em 14/01/2019.
} 
Outro dado significativo sobre o emprego de mulheres em meio período é que apenas $34 \%$ delas optaram por esse tipo de trabalho para conciliar os cuidados e educação das crianças. Essa parcela de mulheres tem qualificação profissional e dispõe de emprego estável, contudo, isso também desfavorece a carreira, já que essas mulheres passam a ter maior dependência do cônjuge na partilha de responsabilidades e com desigual compartilhamento das tarefas domésticas (BUCAS-FRANÇAIS; PENIT-SORIA; SAVEY, 2006). Com relação às profissões, as feministas analisam que as mulheres - tanto em empregos qualificados quanto nos de natureza informal - são absorvidas pelo setor de prestação de serviços, que não são bem remunerados. Na Suécia, as ocupações das mulheres se distribuem geralmente como cuidadoras e profissões afins, concentradas nas áreas de enfermagem, educação e obstetrícia. Observa-se realidade profissional feminina semelhante nos demais países, incluindo a França.

No mercado de trabalho, na seara da Educação, assim como no Brasi1 ${ }^{50}$, as mulheres na Europa ocupam massivamente a profissão de professora, e são as mulheres também as responsáveis por todos os trabalhos desenvolvidos nas creches, berçários e jardins de infância. Qualificadas ou não, 99\% das auxiliares de berçário são mulheres. Observa-se nesse nicho profissional os mais altos percentuais de pessoas não qualificadas. Estima-se que $35 \%$ das pessoas que trabalham nos berçários e $43 \%$ das assistentes maternais não tenham formação pedagógica. Bucas- Français, Penit-Soria e Savey (2006) analisam que a concepção comumente difundida sobre as aptidões de quem se dedica aos setores de cuidados estejam mais ligados às habilidades apresentadas do que as noções necessárias à área, o que não contribui na perspectiva de desconstrução das desigualdades de gênero. Cabe aqui reiterar que a mulher continua sendo invisibilizada e deslegitimada como profissional docente.

Diferentemente das competências, elas são consideradas intimamente constitutivas da personalidade e relacionadas ao pertencimento do sexo, mas não relacionadas ao nível de qualificação e remuneração. Assim, desenvolve uma visão naturalista dessas qualidades, muitas vezes consideradas inatas. Essas qualidades estão, de fato, intimamente relacionadas com as dimensões relacionais dos ofícios e associadas às representações da "natureza feminina". Atenção, escuta, presença, compreensão, psicologia, simpatia por todos os setores estudados, mas também pela inteligência do coração, ternura, dedicação, gentileza (BUCAS-FRANÇAIS; PENIT-SORIA; SAVEY, 2006, p.33-34).

O retorno a uma concepção conservadora de gênero é situado pelas estudiosas feministas como resultado da prioridade delegada às indicações das discussões da Comissão

${ }^{50}$ Dados divulgados pelo Ministério da Educação noticiam que 97,9\% das educadoras/professoras da Educação Infantil são mulheres. Fonte: http://www.todospelaeducaçao.org.br. Acesso em 03/03/2011. 
Europeia desenvolvidas no âmbito da Estratégia Europeia de Emprego, em que, como bons adeptos da doutrina neoliberal, reconhecem a importância dos cuidados da infância para que as mulheres acessem o mercado de trabalho, mas ocultam o quão lucrativo é mascarar - sob o argumento de uma "engenharia familiar" necessária ao desenvolvimento - o real significado da conjuntura profissional feminina: empregos precários, desvalorizados e desqualificados (BUCAS-FRANÇAIS; PENIT-SORIA; SAVEY, 2006).

Concluindo essa densa análise sobre as creches, serviços de atenção à infância e os direitos das mulheres, e como forma de revigorar as forças para que se continue lutando contra essas ofensivas que afetam as crianças e as mulheres na Europa, as feministas francesas propõem que o cuidado das crianças seja articulado de modo coletivo, criando mais vagas em creches e tornando um direito legal o acesso de crianças menores de 3 anos à instituições de cuidado e educação, assim como a integração das creches ao sistema público nacional de educação. É também fundamental que se estabeleçam modelos de qualidade relacionados ao trabalho nas instituições de atendimento à infância, como o reconhecimento da qualificação profissional, revisão de acordos trabalhistas, construção de carreira e formação. Desta forma, se prestigia a criança e também a mulher, que assim como os homens, têm direito à um emprego genuíno, valorizado e de tempo integral (BUCA- FRANÇAIS; PENIT -SORIA; SAVEY, 2006).

Uma contraposição interessante socializada pelo trabalho de Buca-Français, PenitSoria e Savey (2006) é a iniciativa de um serviço em Saint- Etienne du Rouveray, localizada na região da Normandia, que ilustra a materialização das propostas feministas. Esse município possui, desde o ano de 1992, um centro polivalente público criado pelo Conselho Geral e Conselho Regional. A Casa da Primeira Infância busca soluções originais que procuravam satisfazer as necessidades das famílias, e socializar as crianças gradualmente à escola obrigatória. A citada estrutura coletiva atende crianças menores de 6 anos. Há setores em que as crianças são atendidas de modo regular e também em situações ocasionais, com capacidade para 18 e 14 crianças, respectivamente. O jardim de infância conta com o berçário, creche extracurricular e centro de lazer. A instituição nasce a partir de preocupações com as dificuldades sociais e econômicas do município, e realiza intercâmbios com outras creches locais, assim como iniciativa brasileira na qual as crianças de cidade paranaense contam com creches no período noturno, mencionada nesse trabalho. Isso denota o quão importante é a vontade política da sociedade em concorrer para as mudanças e satisfação das necessidades e demandas de uma dada realidade. 
Findando o panorama dos Feminismos e lutas por igualdade de gênero e creches na Europa, a partir da análise da obra das feministas Anne Bucas-Français, Jacqueline PenitSoria e Nicole Savey. Com esse mesmo foco, também acessamos as batalhas das mulheres na América do Sul, pela ótica do texto das professoras Nancy Saporta Sternbach, Marysa Navarro-Aranguren, Patricia Chuchryk e Sonia E. Alvarez (1994) e em especial as lutas feministas e demanda por creches no Brasil pelo olhar de Amelia Teles, Céli Pinto, Fúlvia Rosemberg, Zilma Oliveira e Roselane Campos. Assim como Campos (2012), essa tese compreende que as crianças pequenas são as mais afetadas pelas desigualdades sociais. As crianças que menos acesso têm a creches e escolas de Educação Infantil são aquelas pertencentes aos estratos mais pobres da classe trabalhadora, o que é agravado também pela raça. Isso se comprova por meio de pesquisas divulgadas nessa tese e por dados da PNAD (Pesquisa Nacional por Amostragem de Domicílios contínua) divulgados em 2018, que noticiam que $33,9 \%$ das crianças de 0 a 3 anos que estão fora da creche pertencem à camada dos $20 \%$ das pessoas mais pobres da população brasileira, ou por falta de vagas ou por não ter creche próxima ao seus domicílios, o que, na camada da população de renda mais alta, ocorre com apenas 6, 9\% das crianças ${ }^{51}$. Diante desse cenário, a situação de desigualdade e vulnerabilidade das infâncias, ao coexistir com a situação da criança cidadã é um dos pontos de interesse do debate dessa tese, na tensão com a cidadania da mulher mãe. Essa confluência reflete-se no equipamento da creche - também ocupada em sua maioria por mulheres - que ao atender esse público, se coloca como corresponsável pela educação em uma perspectiva que se propõe, pela legislação vigente, a ser integral, o que implícita o enfoque das categorias mencionadas nesse texto, ou seja, o gênero, a classe, a raça e a geração.

Ao lado disso, o trabalho da mulher - seja ele na creche ou não - é duramente impactado pela (não)cobertura das citadas instituições. Baseando-se em cruzamento de dados do IBGE, PNAD e Secretaria Municipal de Educação de São Paulo (SP), a pesquisa de Doutorado de Viviane Sanfelice - desenvolvida na Universidade de Rochester em Nova York - apurou que a oferta de creches públicas aumentam as chances de a mulher se empregar em 44 pontos percentuais, se comparados à localidades que não disponibilizam esse serviço, o que visibiliza a desigualdade da participação das mulheres no mercado de trabalho e, em consequência disso, a discrepância em termos de renda para além das já conhecidas diferenças salariais entre mulheres e homens. A questão do acesso ao mercado de trabalho persiste.

\footnotetext{
${ }^{51}$ Fonte: https://g1.globo.com/educacao/noticia/um-terco-das-criancas-de-0-a-3-anos-mais-pobres-dobrasil-estao-fora-da-creche-por-falta-de-vaga-diz-ibge.ghtml Acesso em 27/02/2019.
} 
Mesmo porque, diante das sociabilidades contemporâneas em que as mulheres exercem um papel considerável também perante o provedorismo do lar, a suspensão de suas atividades laborais por um grande lapso de tempo impactaria a situação financeira de suas famílias. A nível macro, a (não)atuação das mulheres como população economicamente ativa foi analisada por Elisabeth Badinter (2009), que pondera que sobre a probabilidade de recessão da economia, no que "certamente o emprego das mulheres seria atingido". Como atualmente é impensável o retorno das mulheres ao âmbito do lar, no sentido de se apresentar como a única perspectiva de existência possível, compreende-se o porquê de muitas mulheres se sentirem desencorajadas a vivenciar a maternidade, tanto pelo peso da responsabilidade para com as condições materiais necessárias à educação das crianças, quanto pela culpabilização difundida socialmente de que uma mãe deve à criança todo o suporte emocional e afetivo (BADINTER, 2009), o que destoa e desconsidera tanto as suas pretensões pessoais quanto a participação de outras pessoas, do Estado e da sociedade como um todo na obrigação de maternar. Isso foi apontado no recorte histórico dos embates feministas na luta por creches, frente à distintas concepções políticas e sociais dos governos, bem como as regulações econômicas de organismos internacionais no Brasil e em vários países do mundo que interferem no apoio financeiro e ideológico conferido à Educação e aos mecanismos de cuidado das famílias (BUCA- FRANÇAIS; PENIT -SORIA; SAVEY (2006); TELES (2003); CAMPOS (2012)).

Em contexto brasileiro, vale lembrar que o conceito de vulnerabilidade social se sobressai ao direito à Educação. É fundamental o papel do poder público na interferência e no provimento aos direitos e proteção das crianças, como na atuação e fiscalização dos Conselhos Tutelares, e na promoção de políticas de combate à violência de gênero sofrida pelas mulheres, como apontado em conclusões de pesquisa de Mestrado (RAMOS, 2016) já mencionada em outros momentos. O que se pretende discutir é que o necessário controle social exercido pela interferência do poder público concorre para que se visibilize apenas a figura da mãe no cumprimento das obrigações com as infâncias, o que invisibiliza outros agentes sociais comprometidos por lei com a educação das crianças, o que configura uma desigualdade a ser debatida e superada.

Essas e outras tensões foram apresentadas e discutidas com a equipe da creche participante da pesquisa, se propondo a debater e dimensionar o controle social sofrido pelas crianças e pelas mulheres, tocadas pela vulnerabilidade social e econômica, assim como o papel das políticas sociais e dos Conselhos que asseguram e debatem sobre os direitos desses 
grupos, notadamente perpassados pelas questões de classe, gênero, raça e idade. Desse modo, os textos e obras aqui discutidas demonstram que, mesmo com propostas políticas concretas de emancipação e superação das desigualdades sociais e educacionais, como o conhecido e não superado debate sobre a cobertura de creches, mulheres e crianças continuam a ser interpretadas e atendidas de modo desigual, o que fere a condição de cidadania conferida pelo Estado Democrático de Direito ${ }^{52}$.

Essa incoerência necessita ser combatida, ao que os estudos feministas ferrenhamente apontam como cerne a ideia consagrada do amor materno, cujo entrave necessita ser superado, como debatido nas obras de Badinter (1985; 2009) e Chodorow (1990), sob pena de seguirem naturalizados conhecidos modelos de idealização da figura da mulher e a injusta divisão de tarefas e responsabilidades com os cuidados e Educação, em um ciclo perverso de perpetuação de desigualdades impostas às mulheres e às crianças, o que afeta a cidadania de ambas. Um caminho possível, apontado pela perspectiva feminista - o qual a presente tese pretende explorar - é a conscientização política acerca das relações de maternagem. Na perspectiva dessa tese, a maternagem, se levada a termo, atuaria em criação de condições justas e fortalecimento do trabalho das mulheres, dentro e fora da Educação Infantil. Compreende-se que uma Educação que compartilha as responsabilidades vem a tornar-se mais fraterna e mais democrática, o que reconstrói e reparte às infâncias um contexto mais digno e mais democrático para todas as pessoas, que é justamente o que pretende as formulações e conquistas dos Feminismos.

\footnotetext{
52 O Estado Democrático de Direito se funda: (1) Na soberania popular; (2) Na necessidade de providenciar mecanismos de apuração e de efetivação da vontade do povo nas decisões políticas fundamentais do Estado, conciliando uma democracia representativa, pluralista e livre, com uma democracia participativa efetiva; (3) É também um Estado Constitucional, ou seja, dotado de uma constituição material legítima, rígida, emanada da vontade do povo, dotada de supremacia e que vincule todos os poderes e os atos dela provenientes; (4) A existência de um órgão guardião da Constituição e dos valores fundamentais da sociedade, que tenha atuação livre e desimpedida, constitucionalmente garantida; (5) A existência de um sistema de garantia dos direitos humanos, em todas as suas expressões; (6) Realização da democracia - além da política - social, econômica e cultural, com a consequente promoção da justiça social; (7) Observância do princípio da igualdade; (8) A existência de órgãos judiciais, livres e independentes, para a solução dos conflitos entre a sociedade, entre os indivíduos e destes com o Estado; (9) A observância do princípio da legalidade, sendo a lei formada pela legítima vontade popular e informada pelos princípios da justiça; (10) A observância do princípio da segurança jurídica, controlando-se os excessos de produção normativa, propiciando, assim, a previsibilidade jurídica (SILVA, 2005, p.228-229).
} 


\section{CONHECENDO O TERRENO: A POLÍTICA E O POLÍTICO DA EDUCAÇÃo INFANTIL}

Este capítulo fornece o contexto geral das creches e escolas de Educação Infantil no município de Juiz de Fora (MG), caracterizando a localidade e descrevendo a trajetória política e social atinente ao atendimento das crianças pequenas no município, bem como apresentando o perfil de atendimento. Não obstante, os problemas e contexto específico, a situação do atendimento às crianças pequenas em Juiz de Fora (MG) acompanha o traçado das discussões em nível nacional e a sedimentação das políticas, concepções de infância e entendimentos sobre a criança cidadã, conceito que será debatido também. Uma vez que entendemos que todo contexto local é uma reverberação de um contexto maior, será explorado o entendimento de que a creche é um dos locus de encontro entre o público e o privado, tanto em formulação geral que diz respeito aos interesses da família e do governo (DIDONET, 2001), quanto em seu aspecto mais específico, foco desta tese, que é o de consolidar os direitos de crianças e mulheres via maternagem.

Para a construção deste capítulo, foram utilizadas dissertações e teses que recuperam o contexto nacional e local da Educação Infantil e das políticas educacionais, ao lado de aprofundamento apoiados em autoras de referência, como Fúlvia Rosemberg, Patrícia Corsino, Maria Fernanda Nunes e outras acessadas em busca bibliográfica. Além das discussões políticas, as relações da construção da cidadania se tangenciam pela dimensão da Educação e pelas iniciativas que buscam operacionalizar as melhorias da Educação das crianças pequenas pelos marcos educacionais e legais, disponibilização de recursos entre outros. O final da década de 1970 e início da década de 1980 foi bem movimentado em todo o mundo em olhar prestigioso às crianças pequenas e à Educação infantil por conta do Ano Internacional da Criança (AIC) em 1979. A instituição do citado ano como marco se deu a partir das dissonâncias para com a Declaração dos Direitos da Criança, formulada em 1958 pela Organização das Nações Unidas.

Decorridos 20 anos da formulação da Declaração, milhões de crianças viviam (e ainda vivem) em condições de degradação humana. No ano de 1976, em Comissão Parlamentar de Inquérito (CPI) - conhecida como CPI do Menor - houve o diagnóstico de que havia 25 milhões de crianças carentes e abandonadas no Brasil, ao lado da escassez de recursos para a assistência das mesmas, o que movimentou as estruturas de atendimento e reconhecimento social das crianças brasileiras. Esse percurso é recuperado no presente capítulo. 


\subsection{A DEMOCRATIZAÇÃO DA EDUCAÇÃO INFANTIL NO BRASIL}

As preocupações acerca da educação destinada às crianças de 0 a 5 anos de idade não é fato recente no Brasil. Conforme a tese de Doutorado Políticas Públicas de Educação Infantil em Juiz de Fora - MG: Escolas Municipais de Educação Infantil da professora brasileira Alesandra Maia Lima Alves (2016), é com a promulgação da Constituição de 1988 e com a regulamentação da Lei de Diretrizes e Bases da Educação Nacional de 1996 (Lei n ${ }^{0}$. 9394/96) que a expressão Educação Infantil passou a designar todas as instituições de atendimento para crianças pequenas. Sobre as concepções pedagógicas da Educação Infantil, o trabalho de Maia (2016) corrobora os estudos de Campos (2011), que explanou, no capítulo anterior, sobre a caracterização da dualidade do atendimento ao público, no que diz respeito à relação direta com a classe social e com a raça. A autora nos recupera que as concepções pedagógicas "estiveram próximas daquilo que cada momento histórico construiu, reservou e atribuiu para o que é ser criança e ter uma infância" (MAIA, 2016, p.74), o que pressupõe que a creche também seja concebida como um território, assim como o concebe Haesbert (2004), citado no capítulo 2 , no qual nos baseamos para reler esse conceito a partir da possibilidade de interlocução democrática. Nesse contexto, serão apresentados os diálogos relativos ao reconhecimento da cidadania das crianças via Educação, as tendências, meios e o envolvimento de atores sociais na trajetória de construção da Educação Infantil brasileira, com destaque para o enlace com as sociabilidades das mulheres e o papel das instituições e políticas públicas.

$\mathrm{O}$ entendimento sobre a necessidade das creches nasce propondo um desafio aos reformadores republicanos, em equacionar os modos de vida doméstica com o mundo do trabalho, notadamente pelas classes populares, nos séculos XIX e XX, junto às expectativas de que as crianças eram o futuro da nação (Rosemberg 1999). De acordo com a perspectiva higienista da época, a pobreza, a ignorância e o abandono da mãe eram os principais "problemas" da criança. Rosemberg (1999) atesta que o primeiro texto referente às creches que se tem registro no Brasil consta de publicação da revista Mãi de Família, no ano de 1879. O médico K. Vinelli, responsável pela Casa dos Expostos da Santa Casa de Misericórdia do Rio de Janeiro, escreveu à época:

A creche é um estabelecimento de beneficência que tem por fim receber todos os dias úteis e durante as horas de trabalho, as crianças de dois anos para baixo, cujas mães são pobres e de boa conduta, e trabalham fora de seu domicílio [...] No Brasil, ainda não existe a creche, entretanto, sua 
necessidade me parece palpitante, sobretudo, nas atuais condições em que se acha o nosso país depois da moralizadora e humanitária Lei de 28 de setembro de 1871, em virtude da qual não se nasce mais um escravo. Agora que, graças à iniciativa do governo e dos particulares em não pequena escala, com a emancipação da escravatura vai desaparecendo o vergonhoso estigma que a civilização repele e abomina, um grande número de mulheres que quando escravas trabalhavam para seus senhores que por sua vez eram obrigados a lhes dar alimentação, domicílio e vestuário, a cuidar de sua saúde e de seus filhos, ganhando liberdade, veem-se, não poucas vezes abandonadas com filhos pequenos, que ainda mamam, sem ter quem os sustente, na indeclinável e urgente necessidade de procurarem pelo trabalho, ganhar os meios da própria subsistência, e de seus filhos e em muitos casos, sem poderem consegui-lo porque a isso as impedem como obstáculo insuperável os filhos pequenos, que elas não têm a quem confiar e cuja tenra idade não lhes permite mandá-los para a escola. Não há senhora alguma dona de casa, que ignore a extrema dificuldade senão impossibilidade que encontra uma criada, por exemplo, em alugar-se quando traz um filho a quem amamenta. [Com a criação da creche] a mãe já não encontra dificuldade em empregar-se e pode então tranquila dedicar-se ao trabalho que lhe há de trazer-se os meios de manter-se (CIVILETTI, 1991, p. 36-37 apud ROSEMBERG, 1999, p. 12-13).

O fragmento do texto do Dr. Vinelli é a comprovação da contundente afirmação de Fúlvia Rosemberg (1999, p.12) acerca da concepção brasileira sobre as creches: "a creche não foi pensada para a 'produção' de qualquer ser humano, mas dos filhos recém-libertos das escravas". A esse cenário se somam as já debatidas vinculações do sexo feminino à responsabilidade familiar e com trabalhos de cuidados e educação - aspectos marcantes e recorrentes da Educação Infantil - abordados em outros momentos na tese por trabalhos como os de Badinter (1985;2009), que discute sobre a relação da mulher com o advento da maternidade, e seus atributos; Hirata $(2012$; 2016), que debate sobre as mulheres serem predominantemente as trabalhadoras dos cuidados; e Sorj (2014), cujo olhar se volta à precarização do trabalho das mulheres, em detrimento dos trabalhos domésticos. Os apontamentos das citadas autoras ainda se fazem presentes tanto na organização quanto no perfil atual das trabalhadoras da Educação Infantil, nacional e local, como será exposto ao longo do capítulo, no qual observa-se um quadro de avanços e estagnações, no que concerne à organização da creche, enquanto instituição e como política pública.

Dados do ano de 2018 divulgados pelo INEP estimam que no Brasil existiam 69.745 creches. Dessas, 41.586 são públicas e 28.159 são privadas ${ }^{53}$. Conforme pesquisas de Moysés Kuhlmann Jr. (1998), em meados do século XIX, as primeiras iniciativas relacionadas às creches e pré-escolares surgem como uma proposta inovadora à época: trata-se de um

\footnotetext{
${ }^{53}$ Fonte: Ministério da Educação (MEC)/Instituto Nacional de Estudos e Pesquisas Educacionais Anísio Teixeira (Inep)/Diretoria de Estatísticas Educacionais (Deed).
} 
alargamento da assistência. Segundo o autor, o conjunto de medidas que abarcavam questões como a nutrição, habitação e pobreza eram admitido como elaboração "moderna" e "científica", exaltando-se a ideia de progresso. A creche foi vista como uma substituição à Casa dos Expostos, "para que as mães não abandonassem suas crianças" (KUHLMANN JR, p.1998, p.82), problema já sinalizado, no capítulo 2, pelo artigo do Dr. Vinelli. Ao lado disso, o professor Vital Didonet (2011) alega que a importação dos modelos europeus de jardins de infância, marcantes desse período, reforçaram o caráter assistencial da creche e o caráter educativo da pré-escola.

Se as condições econômicas eram fatores que influíam fortemente no tipo de instituição em que as crianças eram atendidas, os objetivos e as atividades também eram determinantes das características desses estabelecimentos. Assim, as creches geralmente visavam o cuidado físico, saúde, alimentação, formação de hábitos de higiene, comportamentos sociais. Incluíam, por vezes, orientações à família sobre cuidados sanitários, higiênicos pessoais e ambientais, orientações sobre amamentação e desmame, preparação de alimentos e relacionamento afetivo. O jardim de infância, de inspiração froebeliana, tinha outro olhar para a criança: seu desenvolvimento físico, social, afetivo e cognitivo, por meio das atividades lúdicas, do movimento e da autoexpressão (DIDONET, 2001, p.17).

É pertinente salientar que a criação de creches, ligadas à necessidade de regulamentação das relações de trabalho, particularmente o feminino (KUHLMANN JR, 1998; ROSEMBERG, 1999) traz à tona, além da discussão sobre a maternidade, o trabalho e a dimensão dos cuidados e das responsabilidades, a questão do risco social eminente expressa pelas participantes da pesquisa de campo, que observam que "[...] às vezes, o único lugar que existe alimentação é aqui”. A pobreza como uma ameaça social faz parte das históricas preocupações higienistas, e se fazem ainda presentes em contexto atual, como um argumento que é cúmplice da manutenção de práticas que denotam uma construção social conservadora. Essas preocupações e argumentos acabam por secundarizar as origens causadoras da questão da pobreza e da fome no Brasil, ainda muito presentes em seus desdobramentos, no cotidiano, como por exemplo, as nossas origens escravagistas nos processos da formação social brasileira. 
Figura 3. 1: Família pobre recolhendo o produto do trabalho da negra velha que carrega água" (Jean-Baptiste Debret, 1827)

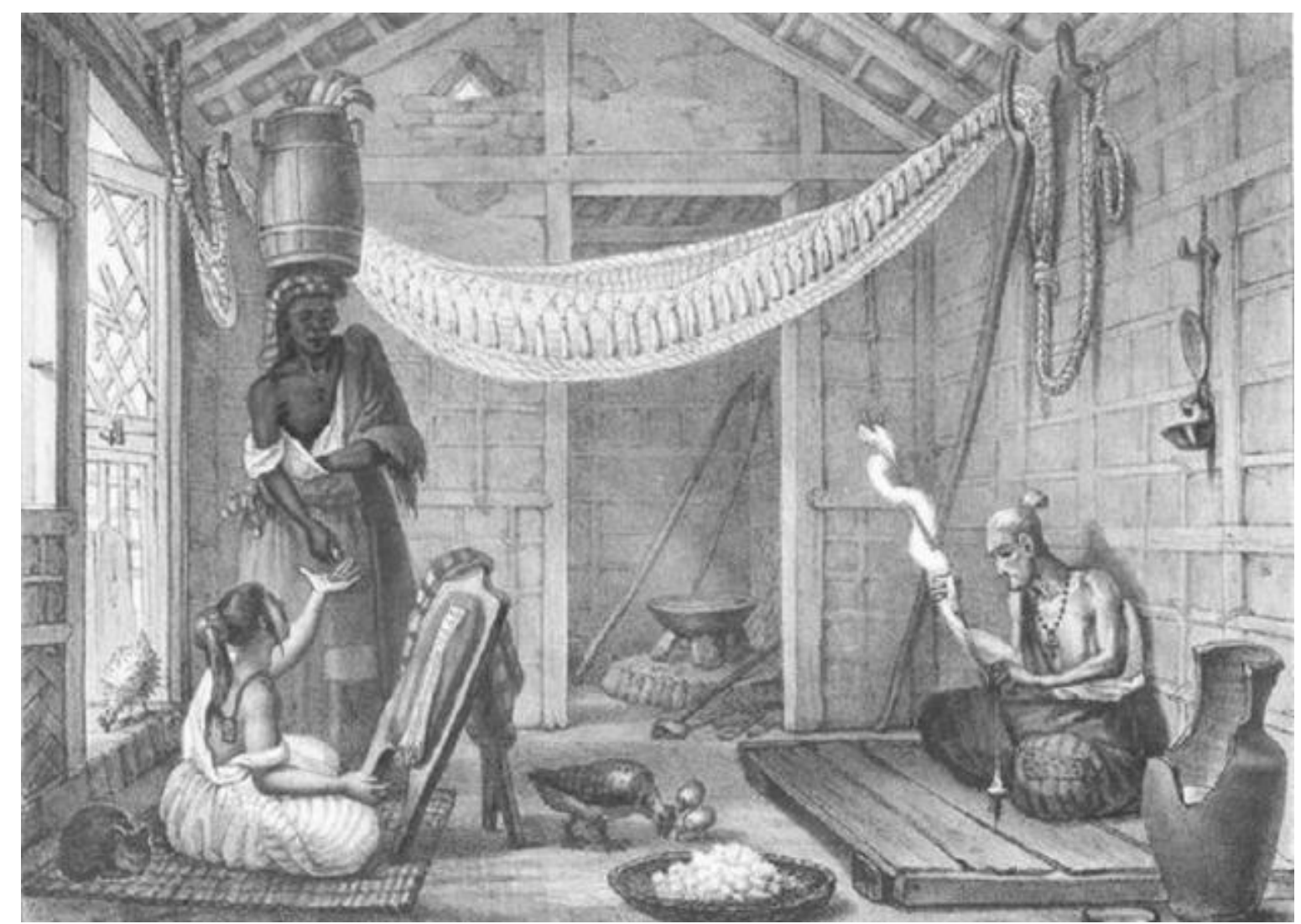

Fonte: https://ensinarhistoriajoelza.com.br/contrastes-sociais-brasil-colonia-debret/

É a partir desse entendimento que a creche passa a ser compreendida como um "mal necessário", e não como um direito, mas como condição de progresso do país. Essa condição se pautava a partir de uma linha divisória que colocava crianças pobres, negras, órfãs, descendentes dos povos indígenas, deficientes de um lado e de outro as crianças brancas, filhas das classes média e alta, como aponta o livro Educação Infantil no Brasil: primeira etapa da Educação Básica de autoria de Maria Fernanda Resende Nunes, Patricia Corsino e Vital Didonet publicado em 2011. A escolarização era tida como promotora do desenvolvimento, o que não seria grave se as fontes estudadas e os relatos da pesquisa de campo não apontassem que as desigualdades socioeconômicas estiveram associadas a uma possível "ameaça" à ordem nacional e social, identificada pela categoria das infâncias. Ao lado da esperança e dos avanços depositados nas gerações futuras, mais uma vulnerabilidade se constrói.

Para demonstrar esse argumento - a necessidade de combater as "ameaças" à ordem social - recuperamos rapidamente a vigência da esfera jurídica. A preocupação com as 
infâncias se consolida com a criação do Código de Menores, conhecido como Código de Mello Mattos, no ano de 1927. Destinado a proteger a infância moralmente abandonada, o Código de Menores se propunha a ser a base legal a qualquer ato que tratasse de "menores abandonados, delinquentes ou em situação de o ser" (ZANELLA; LARA, 2015, p.116). Sob a Doutrina da Situação Irregular, o citado Código regulamenta as ações destinadas à proteção e ao controle social. Somando às desigualdades de gênero, raça e classe, acrescenta-se, ainda, a desigualdade geracional. O Código, ao utilizar a denominação menor traz a perspectiva que não reconhece a criança como pessoa, mas como não-pessoa, cujo entendimento possui similaridades com o movimento que Lopes (2008) caracterizou como a produção do lugar e o não-lugar, no que toca às presenças, em simultaneidade da construção da ausência, como já debatido no capítulo 2. Sobre essa "condição" da infância, Nunes, Corsino e Didonet (2011) descrevem que a legislação da época encarava a criança ora como uma pessoa menor, pobre e infratora, logo, questão de segurança; ora uma pessoa menor, abandonada e fragilizada, logo, objeto de assistência. Esse entendimento perdurou até a promulgação do Estatuto da Criança e do Adolescente em 1990, que trouxe consigo “[...] a revolução conceitual e criar os mecanismos operacionais para a implementação dos direitos da criança no Brasil" (NUNES; CORSINO; DIDONET, 2011, p.26), o que será aprofundado nos próximos momentos da tese.

De volta à creche, no Brasil, a primeira creche destinada às crianças filhas de operárias/os foi fundada no ano de 1899, na Companhia de Fiação e Tecidos Corcovado, no Rio de Janeiro (KULHMANN JR., 1999). Já os primeiros jardins de infância surgiram em 1875, 1896 e 1904, também no estado do Rio de Janeiro, e em 1896 no estado de São Paulo, em atendimento às classes média e alta. Outra iniciativa de projeção foi a fundação do Instituto de Proteção e Assistência à Infância do Brasil no ano de 1880, pelo médico Arthur Moncorvo Filho, que foi árduo defensor da organização de serviços públicos voltados às crianças. Conforme Kuhlmann Jr.(1999), o citado Instituto possuía, no ano de 1929, 22 filiais, inclusive uma delas na cidade de Juiz de Fora (MG), localidade desse estudo.

Apesar de compactuar com a perspectiva higienista - exercendo o que a médica brasileira Maria Marta Luna de Freitas nomeou como caridade científica - prestando serviços ligados à assistência social, como atender menores, recém-nascidos, regular serviços de amas de leite, criar maternidades, creches e jardins de infância, "o Instituto exerceu grande influência nas concepções sobre criança e sociedade, na responsabilidade pública em relação à saúde, integração social e desenvolvimento das crianças" (NUNES; CORSINO; DIDONET, 2011, p.19), incluindo a saúde da mulher gestante. Tais preocupações foram amadurecendo 
até o nascimento de formulações relativas às políticas públicas e condições técnicas para a disponibilização dos serviços de educação e cuidados, sempre articuladas às políticas voltadas à saúde.

Outro grande marco histórico brasileiro foi o Congresso de Proteção à Infância, realizado o ano de 1922, em que surge a sugestão de construção de espaços em que as mulheres pudessem amamentar suas crianças nos locais de trabalho, sem prejuízo de salário, o que veio a se tornar lei na Consolidação das Leis de Trabalho em 1943.

Ainda conforme o estudo de Nunes, Corsino e Didonet (2011), o mesmo Moncorvo Filho empreendeu a fundação do Departamento da Criança no Brasil no ano de 1919. O Departamento era responsável por zelar pelas leis de proteção à infância, realizar e divulgar estudos sobre esse tema, promover congressos e fomentar ações que visassem o desenvolvimento infantil numa perspectiva integral. Já em 1940, foi fundado o Departamento Nacional da Criança (DNCr), que, para além dessas funções, também, coordenava atividades relativas à adolescência e à maternidade, o que se insere no amadurecimento mencionado, e expansão do olhar para com as crianças, inclusive pelo fato de o Departamento se vincular ao então Ministério da Educação e Saúde Pública (MIESP). Em 1953, as questões de saúde passaram a ser atribuições de um ministério específico, o que ocasionou a vinculação do Departamento ao Ministério da Educação e Cultura (MEC). Em 1970, o citado Departamento foi renomeado como Coordenação de Proteção Materno-Infantil, e hoje suas atribuições estão situadas na Coordenação de Saúde Mental (NUNES; CORSINO; DIDONET, 2011).

É digno de nota que, em 1952, o Departamento Nacional da Criança lançou uma publicação que continha indicações para que as creches disponibilizassem "materiais apropriados para a educação das crianças pequenas, cuja lista não difere muito das que são feitas hoje" (NUNES; CORSINO; DIDONET, 2011, p.21). Somente em 1967, surgiu o Plano de Assistência ao Pré-Escolar, cuja orientação era no sentido da "criação de escolas maternais e jardins de infância como instituições auxiliares da família na educação de seus filhos pequenos", na faixa etária dos 2 anos. O Plano tinha o objetivo de "promover o desenvolvimento integral harmonioso da criança, por meio de experiências de vida que favorecessem a formação de hábitos sadios e estimulassem a capacidade de adaptação progressiva ao meio social", em que fica demonstrada a valorização da pequena infância. Logo, a preocupação com o atendimento integral, unindo educação e cuidados, ganha o status de política pública, ainda que o Ministério da Educação não prestigiasse a Educação das 
crianças pequenas, devido à lógica de baixo custo, ou seja, construção de uma educação “pobre para os pobres" (NUNES; CORSINO; DIDONET, 2011, p.22).

É pertinente destacar que, em 1969, outro ministério passou a dedicar atenção à criança. O Ministério do Trabalho passou a contar com a ação do Departamento de Segurança e Higiene do Trabalho, cuja responsabilidade era cumprir e fiscalizar as normas de instalação de creches nos locais de trabalho. Por força do Decreto-Lei de número 5.452/1943, os estabelecimentos e empresas que contassem com pelo menos 30 funcionárias mulheres tinham que dispor de um local apropriado para alojar as crianças pequenas no período da amamentação. No entanto

[...] a possibilidade de cumprir a exigência mediante convênio com entidades públicas e privadas para atendimento das crianças em creches distritais, comunitárias ou dirigidas pelo SESI, pelo SESC e pela LBA ampliou o tempo e os objetivos definidos para o "local de guarda" na empresa. A determinação legal não obteve grande aplicação no país e tornou-se inócua como política pública (NUNES; CORSINO; DIDONET, 2011, p.23).

No ano de 1968, houve o I Encontro Interamericano de Proteção ao Pré-escolar, realizado no estado da Guanabara, atual Rio de Janeiro. Tal evento, que envolveu o DNCr, a OMEP $^{54}$ (Organização Mundial da Educação Pré-escolar), a LBA, a FUNABEM ${ }^{55}$ (Fundação do Bem Estar do Menor), a Secretaria de Educação do Estado da Guanabara e o UNICEF, rendeu debates sobre a percepção de políticas públicas integradas para o atendimento e atenção às crianças. De acordo com Nunes, Corsino e Didonet (2011), os principais tópicos de discussão versaram sobre a necessidade de ações interdisciplinares, a relação do desenvolvimento global e a nutrição, a presença de educadores formados nos serviços do préescolar, a articulação de estudos de áreas de conhecimento e a exigência de criação de um departamento específico no Ministério da Educação foram as principais colocações.

Houve também grande ênfase no envolvimento das mães nos serviços psicopedagógicos da escola, o que reforça a figura da mulher como estritamente responsável pela educação das crianças, como mãe ou como educadora, tendência de ação observada

\footnotetext{
${ }^{54}$ Fundada em 1948, a OMEP é uma organização não governamental com estatuto consultivo junto à Unesco, Unicef e Conselho da Europa. A OMEP é representada em comitês nacionais e está presente em uma centena de países. Fonte: https://grupocomunitarioalta.wordpress.com/quemsomos/organizacao-mundia-ensino-pre-escolar-omep/ Acesso em 13/02/2020.

${ }^{55}$ A FUNABEM foi um órgão fundado no período da Ditadura no Brasil, no ano de 1964. Tinha a responsabilidade de formular e aplicar medidas à adolescentes e menores infratores que atentassem contra a ordem social. Situada no âmbito da Ministério da Previdência e Assistência Social, serviu de molde para a criação de instituições equivalentes nos Estados: as conhecidas Febens (Fundação Estadual do Bem Estar do Menor) (NUNES; CORSINO;DIDONET, 2011).
} 
também no município de Juiz de Fora (MG), com a participação das Mães de Creches, detalhada no item dedicado ao município. Ainda que o governo brasileiro fosse pressionado pelos organismos internacionais a dedicarem atenção à infância pela introdução dos debates do citado congresso, o que realmente ocorreu foi o reforço da adoção dos modelos assistenciais e de uma educação pré-escolar de massa, com a contratação de mão de obra mal remunerada e/ou voluntária, com baixa ou nenhuma qualificação profissional (NUNES, CORSINO; DIDONET, 2011; ROSEMBERG, 1999), predominantemente, feminina. O argumento adotado à época foi a necessidade de uma ação rápida, dada a precariedade da situação de atenção às crianças pequenas que ocorria em um contexto de recursos escassos. Ao lado disso, há o barateamento dos programas de educação das crianças pequenas, questão que vagamente era debatida em termos de orçamento, já que o MEC contava com o apoio dos recursos fornecidos pelo Fundo de Assistência Social.

É justamente na busca por uma solução ágil que a mulher é iluminada como responsável pelos processos educacionais da criança. A real intenção do apelo para que a comunidade participe da implantação da política do pré-escolar, segundo Rosemberg (1999), é que os organismos proponentes tão somente se basearam nas "aptidões" supostamente natas dos cuidados atribuídos às mulheres para que o problema da atenção às crianças em países em desenvolvimento se equacionasse facilmente, seguindo, portanto, um modelo simplificado de educação. A mesma autora atesta que tal olhar demarca duas trajetórias na Educação Infantil brasileira: uma baseada na profissionalização, baseada na formação educacional, e outra baseada na lógica doméstico-familiar, no que tange a uma captação da disponibilidade da comunidade, sem a devida profissionalização, ou perpassada por capacitações esporádicas às funções exercidas junto às crianças pequenas. Isso se observou, inclusive, em pareceres do Conselho Federal de Educação, vinculado às ações do MEC, que além de conclamar a participação das famílias nas atividades do pré-escolar, indicavam em seu bojo conhecidas orientações relativas às creches: a utilização de espaços disponíveis ou ociosos, a conscientização da família sobre a importância do pré-escolar, a integração dos atendimentos relativos à nutrição e educação, além da utilização de meios de comunicação para atingir as populações distantes do espaço escolar (ROSEMBERG, 1999). A mobilização popular também foi aspecto marcante do nascimento das creches em Juiz de Fora (MG), em discussão a seguir.

O primeiro grande momento de expansão da rede de creches no Brasil ocorreu durante os Governos Militares. Rosemberg (1999) observa que apenas em 1974 ocorre a criação de 
setor relativo às demandas da Educação Infantil no Ministério da Educação. No citado ano, foi criado o Serviço de Educação Pré-escolar, vinculado inicialmente à Secretaria de Ensino Fundamental, que, em reorganização posterior, passou a se chamar Coordenação de Educação Pré-escolar (COEPRE) e, mais tarde, renomeada para Coordenação Geral de Educação Infantil (COEDI). De modo a favorecer o acesso ao ensino fundamental, o pré-escolar se alinhava, à época, com as já mencionadas indicações da UNESCO e a UNICEF, que recomendavam um atendimento público com adequações à idade da criança, baseados em modelos europeus, por sua vez, materializados no programa Educação Pré-escolar: Uma Nova Perspectiva Nacional, que se tornou o modelo nacional. No entanto, foram as ações oriundas da LBA (Legião Brasileira de Assistência) que tiveram a grande projeção na ampliação das creches. O Projeto Casulo, nascido no ano de 1977, que dispôs de unidades inclusive no município de Juiz de Fora (MG), obteve grande sucesso, visto que utilizou justamente o discurso de combate à desordem social, ao lado da estratégia de diminuição do custo per capita repassado às entidades beneficiárias, consolidando-se antes da política nacional do MEC. O Programa Educação Pré-escolar só foi efetivamente implantado quando da implantação do Movimento Brasileiro de Alfabetização (MOBRAL), que contava com o financiamento e recursos técnicos disponibilizados pela Fundação Mobral, o que redesenha o repasse de verbas, refletindo-se na expansão de vagas do pré-escolar já na década de 1980 (ROSEMBERG, 1999).

Tanto a LBA, quanto o MEC, ao se alinharem com a proposta de educação compensatória - na supressão de carências e escassez de recursos pautados em questões territoriais e socioeconômicas - apresentaram resultados similares, quando da avaliação de suas ações: a baixa formação profissional, materiais pedagógicos insuficientes, ao lado da precariedade das instalações físicas e da alimentação ofertada. Ainda assim, houve uma expansão no atendimento. Acompanhando essa expansão e, ainda, pautando-se na supressão das carências, Fúlvia Rosemberg analisa que os municípios passam a ser estimulados pelo governo a abrirem vagas para as crianças com idade próxima ao ingresso ao nível de ensino obrigatório, o que gera outra conhecida vulnerabilidade da Educação Infantil: o desprestígio como etapa anterior ao ensino fundamental, educação admitida como regular. Em movimento semelhante, em tempo atual, destacamos a criação da vulnerabilidade da Educação das crianças de 0 a 3 anos, surgida perante a obrigatoriedade da escolarização a partir dos 4 anos, instaurada em 2009 no Brasil. Novamente um desprestígio, agora do direito à educação dos bebês. 
Outros contornos também surgem, mesmo com a regulamentação e com o reconhecimento da Educação Infantil como primeira etapa da Educação Básica na ocasião da promulgação da Lei de Diretrizes e Bases da Educação Nacional, como as "[...] soluções opcionais, criadas pela comunidade, como creches domiciliares, creches comunitárias, filantrópicas e até mesmo privadas com fins lucrativos”. Grande parte dessas instituições é fruto de movimentos comunitários, principalmente, de mulheres em luta pelo direito a um lugar digno para deixar os filhos durante a jornada de trabalho, corroborando as análises de Teles (2015). Nesse sentido, a creche segue apresentando duas faces: a do direito, formalmente reconhecido, e a das limitações concretas, em sua existência real e material.

Embora os tempos políticos tenham mudado, as condições precárias de
muitas destas creches mantiveram-se. Várias creches comunitárias ainda
ocupam espaços improvisados, localizados em comunidades pobres, favelas,
invasões, periferias em geral, lugares que, como o seu entorno, funcionam
como podem, com recursos da comunidade e de convênios com o poder
público. São instituições que prestam serviço público - não governamental,
não estatal - junto às camadas mais pobres da população, instituições que
contam com verbas públicas para se manter e que precisam mais do que os
recursos que já recebem dos convênios atuais para poder oferecer um serviço
de melhor qualidade à população infantil pobre, seja com instalações e
materiais mais adequados, seja com pessoas habilitadas para atender as
crianças, entre outras. Se, por um lado, há equívocos sobre as
responsabilidades e as competências municipais e estaduais, por outro, a
política de educação infantil tem assumido novos contornos, adquirindo uma
identidade em relação a referências nacionais de qualidade de serviços, para
a infraestrutura, para a proposta pedagógica, para o funcionamento, para a
definição de um perfil profissional - antes, qualquer pessoa poderia atuar
nessa área -, para o estabelecimento de fontes de recursos
constitucionalmente subvinculadas (NUNES; CORSINO; DIDONET, 2011,
p.50-51).

O reconhecimento da importância da Educação Infantil e a consolidação do direito à Educação desde o nascimento são marcos extremamente importantes à cidadania da criança. Contudo, parafraseando Rosemberg (1999), não é possível desconsiderar a existência de "realidades paralelas". Além dos olhares do atendimento à criança pobre e a desvalorização do trabalho docente pautado nos modelos de gênero, bases de um histórico atendimento de cunho assistencialista, a conquista recente da inclusão da Educação Infantil nos orçamentos do FUNDEB (Fundo de Manutenção e Desenvolvimento da Educação Básica e de Valorização dos Profissionais de Educação) corresponde a um enorme ganho na construção de uma política para a Educação Infantil, no que se refere à intervenção do Estado e à 
projeção da creche como equipamento complementar à ação da família (NUNES; CORSINO; DIDONET, 2011). Entretanto, esse avanço também possui outra face.

O FUNDEB, conforme levantamento divulgado em artigo de nome $O$ financiamento da educação infantil não é brincadeira de criança: entre ausência no Fundef e a insuficiência do Fundeb, de autoria de Wellington Ferreira de Jesus (2008), ainda se mostra como política inócua, pois imprime investimentos tímidos no nível da Educação Infantil. Nas palavras do autor, em termos de investimentos, o FUNDEB transita entre o "mínimo e o "necessário", devido ao custo-aluno de creches e escolas de Educação Infantil, sobretudo, as primeiras, de tempo integral ${ }^{56}$. Segue o impasse de subvinculação de verbas federais insuficientes aos recursos municipais junto ao custo-aluno, ao lado da concentração regional por parte dos mesmos investimentos, tema já debatido também por Campos (2012), ao discutir o investimento de 1 dólar por dia. A esse respeito, concordamos com Rosemberg (1999) sobre o processo de democratização da Educação Infantil brasileira, em que nota-se um descompasso entre a produção científica, o discurso, o reconhecimento social nas políticas públicas e a aplicação concreta desse reconhecimento - como a sobrecarga por parte dos municípios - em afinação com a condição cidadã das crianças pequenas.

A atuação da COEPRE na Comissão Nacional Criança e Constituinte, em meados da década de 1980, teve papel essencial na defesa da criança como sujeito de direitos, especialmente do direito à educação, já a partir do nascimento. As discussões sobre esse entendimento iniciaram no ano de 1985, quando chegam ao fim os governos militares. Uma nova Constituição Federal deveria ser elaborada, no que consistiu intensa mobilização das organizações sociais em apresentar propostas de construção de sociedade e Estado à Assembleia Nacional Constituinte. As crianças são, então, reconhecidas como cidadãs, alçadas com prioridade nas ações institucionais, políticas e administrativas, finalmente atribuída à dignidade a esse grupo.

Sob a coordenação do COEPRE foi criada, segundo nos relata Nunes, Corsino e Didonet (2011), por iniciativa do Ministério da Educação, a Comissão Nacional Criança e Constituinte (CNCC) no ano de 1986. A comissão era composta por representantes dos

\footnotetext{
${ }^{56}$ Conforme dados divulgados pela Portaria Interministerial $n^{\circ} 1027$, de 19/08/2008, o valor-aluno de creches e pré-escolas, em termos de repasses (mínimos e máximos) eram, para as creches integrais, de aproximadamente $\mathrm{R} \$ 1.245,58$ e $\mathrm{R} \$ 2.925,25$. Às creches parciais os valores estimados eram de $\mathrm{R} \$ 905,57$ e $\mathrm{R} \$ 2.055$, 24. Já os pré-escolares integrais tinham de ter investidos, por aluno, o valor mínimo de $\mathrm{R} \$ 1302,20$, com o máximo chegando a $\mathrm{R} \$ 2055,24$. Na modalidade parcial, a estimativa de verba dos pré-escolares contava com o valor mínimo de $\mathrm{R} \$ 1019,11$ por aluno, chegando ao máximo de R $\$ 2.312$, 14. (NUNES, CORSINO, DIDONET, 2011, p.63). O artigo de Wellington Cruz (2008), também explora as discordâncias e impedimentos sobre esses valores.
} 
ministérios da Educação, da Previdência e Assistência Social, da Cultura, da Saúde, do Planejamento e do Trabalho, bem como organizações sociais e civis, como a Sociedade Brasileira de Pediatria (SBP), a Pastoral da Criança e Conferência Nacional dos Bispos do Brasil (CNBB), a Organização Mundial para a Educação Pré-escolar/Brasil (Omep), o Conselho Nacional dos Direitos da Mulher (CNDM), a Ordem dos Advogados do Brasil (OAB), o Movimento Nacional Meninos e Meninas de Rua (MNMMR), a Frente Nacional dos Direitos da Criança (FNDC) e a Federação Nacional dos Jornalistas (FENAJ). Tais instituições tinham em comum o interesse pelas crianças, representando, além da esfera governamental, diferentes áreas de atuação social voltadas a esse público. Notável, também, foi a intensa participação das crianças em manifestações públicas, como reuniões, seminários, congressos, assembleias e debates nos mais diversos ambientes (NUNES, CORSINO, DIDONET, 2011). A Comissão organizou o Movimento Nacional Criança e Constituinte, com comissões presentes em todos os estados.

$\mathrm{O}$ funcionamento das comissões (nacional e estaduais) durante dois anos, numa diversidade de ações técnicas e políticas, demonstrou que o tema dos direitos da criança na sociedade brasileira é capaz de reunir, unir, mobilizar e produzir resultados que alteram o rumo da história do atendimento à criança. O que aconteceu no âmbito federal ocorreu, também, em todos os estados e no Distrito Federal. A criança foi assunto de debates na Assembleia Nacional Constituinte, nos ministérios envolvidos, na imprensa (TV, rádio, jornais e revistas), nas escolas e nas pré-escolas, em universidades, nas Assembleias Legislativas e nas Câmaras de Vereadores, em consultórios pediátricos, salas de advocacia, igrejas, sedes de movimentos sociais. Um abaixo-assinado com 1,2 milhão de assinaturas, conseguidas por crianças, pais, profissionais e imensa quantidade de jovens voluntários, pedindo a inclusão dos direitos da criança na Constituição, foi entregue ao vicepresidente da Assembleia Nacional Constituinte sob os flashes dos jornalistas, que estamparam as imagens na TV e nos jornais no dia seguinte. Todo esse movimento levou a uma visão de criança mais ampla que a de menor, e ela passou a ser concebida como cidadã: não mais como problema, mas como pessoa sujeito de direitos, não mais fracionada em áreas independentes - físico, social, afetivo, cognitivo -, mas um ser indivisível que requer, para ser compreendido e adequadamente atendido, atenção integral (NUNES; CORSINO; DIDONET, 2011, p.29).

Logo, a construção coletiva e democrática fomentou as novas regulamentações que consolidaram os direitos das crianças previstos na Constituição, como o Estatuto da Criança e do Adolescente (ECA) e a Lei de Diretrizes e Bases da Educação Nacional, além da Lei Orgânica da Assistência Social (LOAS). 
Um importante passo na garantia do direito à educação deu-se quando ela passou a ser definida como direito público subjetivo, o que significou poder de ação na proteção e na defesa de um bem considerado inalienável e, ao mesmo tempo, legalmente reconhecido (HORTA, 1998, p. 6). Este poder de ação implica acionar o poder público e mobilizar instâncias da sociedade civil organizada no caso da falta de atendimento à demanda pela educação NUNES; CORSINO; DIDONET, 2011, p.73).

Criada em 1993, a LOAS segue acompanhando a diretriz constitucional "de que a assistência é um direito do cidadão e um dever do Estado e se destina a quem dela necessitar". Desse modo, se estabelece que o atendimento público adote a perspectiva da proteção integral, visando garantir “[...] os mínimos sociais, ao provimento de condições para atender contingências sociais e à universalização dos direitos sociais", o que leva ao distanciamento dos propósitos do assistencialismo (NUNES; CORSINO; DIDONET, 2011, p.25). Indiscutivelmente, a LDBEN, ao definir a Educação Infantil como primeira etapa da Educação Básica e atribuir "como finalidade o desenvolvimento integral da criança até seis anos de idade, em seus aspectos físico, psicológico, intelectual e social, complementando a ação da família e da comunidade" (BRASIL, 1996, art. 29) é um dos maiores marcos legais educacionais. Além de regular a profissionalização e a formação, por meio dos termos do artigo 62, a LDBEN socializa o papel da creche em iniciar a formação integral da criança, ao passo que a pré-escola segue esse mesmo processo.

Em relação às novas elaborações sobre a Assistência, regulamentada pela Lei Orgânica da Assistência Social, acompanhando esse movimento, no ano de 1995, a LBA encerra as suas ações. As atividades e convênios referentes às creches comunitárias, e também algumas municipais a essa altura, passam a ser responsabilidade da Secretaria de Assistência Social do Ministério da Manutenção, que existiu até o ano de 2008. Ainda em 2007, o Ministério do Desenvolvimento Social (MDS) ${ }^{57}$ autorizou a utilização do Piso Básico de Transição (PBT) por parte dos municípios que transferissem a rede de Educação Infantil da competência das Secretarias de Assistência Social para as Secretarias de Educação.

Esses recursos poderiam ser destinados a ações socioeducativas de apoio a famílias de crianças de 0 a 6 anos vulnerabilizadas social ou economicamente, em serviços ofertados pelos Centros de Referência da Assistência Social (CRAS). Em 2009, houve a transição definitiva da gestão das creches ao Ministério da Educação, o que consolidou, além da

\footnotetext{
${ }^{57}$ Atual Ministério do ''Desenvolvimento Social e Combate à Fome. A renomeação ocorre em 2004, quando se somam às competências do Ministério a responsabilidade sobre o Programa Bolsa Família.
} 
reformulação sobre a assistência, a clara caracterização da creche como instituição educacional a partir das legislações (NUNES, CORSINO, DIDONET, 2011).

Nas legislações educacionais, as adequações das prescrições são mais notáveis a partir de 1996. A década de 1990 foi marcada por debates do MEC junto a gestores municipais e estaduais de educação para que fossem definidas as linhas de ação para as melhorias da Educação Infantil. Esses debates geraram o documento Política Nacional de Educação Infantil: pelo direito das crianças de zero a seis anos à Educação (BRASIL, 2006). Com o objetivo de garantir o direito à Educação, mediante a ação de colaboração entre municípios, estados e União, o documento debate as respectivas competências dos entes federados, ressalta a importância da qualificação do atendimento, disponibiliza orientações técnicas e estratégias, a fim de fortalecer o sistema educacional. E enfatiza a relevância da formação e participação de professoras/es em concorrer na construção da política. Ainda sobre a participação da sociedade nas discussões sobre as políticas educacionais, Nunes, Corsino e Didonet (2011) destacam.

[...] os conselhos municipais de educação antecederam à instituição dos sistemas de ensino, conforme apontam os dados da pesquisa "Perfil dos conselhos municipais de educação de 2006" (BRASIL, 2007b). Há experiências de conselho municipal na década de 1970, mas sua institucionalização ocorreu em 1988. Dos 5.564 municípios brasileiros, verificam-se os seguintes avanços expressivos: 3.127 têm Conselho Municipal de Educação instituído, representando 56\% 49 24. "Dos 2.430 municípios que responderam à referida pesquisa em 2006, 2.038 (84\%) possuem conselho de educação, criado por lei; 1.289 (53\%) possuem sistema de ensino instituído e $1.214(50 \%)$ possuem plano de educação, aprovado por lei municipal. A região Sudeste é a que apresenta índices mais elevados de CMEs (94\%) e PMEs (66\%) instituídos. (NUNES; CORSINO; DIDONET, p.50).

É de grande mote a atuação do Conselho Nacional de Educação, como já destacado no capítulo 1, que contribui em pareceres e resoluções que originaram as Diretrizes Curriculares Nacionais para a Educação Infantil. Documento norteador com força de lei, além de dispor sobre a organização, desenvolvimento e avaliação das práticas pedagógicas da Educação Infantil, as Diretrizes estabelecem os princípios éticos, políticos e estéticos a serem seguidos e as dimensões a serem favorecidas no trabalho pedagógico, tendo como eixo a interação e a brincadeira (RAMOS, 2016).

A expansão da Educação Infantil coloca para debate o grande tema atinente à qualidade. Essa é importante pauta, discutida em seminários, publicações, universidades e 
fóruns de Educação Infantil. Destaca-se o Movimento Interforuns de Educação Infantil do Brasil (MIEIB), ativo desde o período de elaboração da LDB, e as ações da Coordenação Geral de Educação Infantil (COEDI). A COEDI possui a responsabilidade de articular a etapa da Educação Infantil debatendo a relação do cuidar e educar, e de prestar assistência técnica aos Estados, municípios e Distrito Federal, conforme as disposições relativas a esse nível de ensino contidas na LDBEN, PNE e Plano de Desenvolvimento da Educação (PDE).

Considerando as diferenças regionais e as demandas de cada rede, o resultado dos diálogos contínuos do MEC, representado pela COEDI, com a comunidade acadêmica e com representantes e entidades da sociedade civil, resultaram em várias publicações direcionadas às professoras e professores. "Política Nacional de Educação Infantil" e "Por uma política de formação do profissional de educação infantil" foram elaborados no ano de 1994. "Critérios para o atendimento em creches que respeitam os direitos fundamentais das crianças" foram orientações publicadas no ano de 1995, e em 1996 surgiu o documento "Propostas pedagógicas e currículo em Educação Infantil”. No ano de 1998 foi publicado o documento "Subsidios para credenciamento e funcionamento de instituições de Educação Infantil". Também é do ano de 1998 o controverso documento "Referenciais Curriculares da Educação Infantil", criticado pela comunidade acadêmica por sua construção falha e contraditória $^{58}$. No que diz respeito à avaliação da Educação Infantil, o MEC publicou, em 2009, o documento "Indicadores da qualidade na educação infantil”, que é um instrumento de autoavalição que visa a subsidiar o olhar respeitoso para com os direitos fundamentais das crianças.

Tais iniciativas, mediadas pela COEDI, constituíram significativas ações de reflexões sobre os cotidianos e as múltiplas dimensões do trabalho docente com as crianças pequenas, em especial, realizado sob um trabalho coletivo. O trabalho coletivo, se pensado em movimento dialógico, de disputas, debates e consideração das distintas interpretações possíveis advindas dos diálogos em conjunto de vários segmentos, como a COEDI, ao lado do MEC, universidades, docentes e sociedade civil, se aproxima do modelo agonístico defendido por Mouffe, como materialização democrática dos pressupostos da Educação Infantil, e como consequência, um modo de a sociedade exercer a maternagem das crianças pequenas, tendo

\footnotetext{
${ }^{7}$ Uma melhor exploração das críticas ao RCNEI pode ser acessada em minha Dissertação de Mestrado Relações de Gênero e docência na Educação Infantil: interfaces entre políticas públicas e abordagens pedagógicas (2016). Tais críticas são embasadas pelas análises da professora Ana Beatriz Cerisara, cujo texto $A$ produção acadêmica na área da educação infantil a partir da análise de pareceres sobre o referencial curricular nacional da educação infantil: primeiras aproximações (1999) é referência nesse tema.
} 
em vista o árduo trabalho de reflexão acerca das dimensões envolvidas nos trabalhos pedagógicos destinados a elas.

Esses documentos atuam de maneira significativa a subsidiar os trabalhos pedagógicos, permeados pela reflexão, avaliação e construção coletiva, impondo às práticas o caráter da profissionalização. $\mathrm{Na}$ ocasião da promulgação da LDBEN, outra mudança foi a exigência da formação inicial superior, "em curso de licenciatura, de graduação plena, em universidades e institutos superiores de educação, admitida, como formação mínima para o exercício do magistério, a oferecida em nível médio, na modalidade Normal" (NUNES; CORSINO; DIDONET, 2011, p.67). Isso gera uma definição, e logo um reconhecimento, da categoria profissional, o que leva à incursão em plano de carreira de 30 ou 40 horas semanais, com remuneração em acordo com a formação a nível médio ou superior. A mesma lei passa também a mencionar a formação continuada. Dentre outras iniciativas de destaque, houve a criação do Programa Proinfantil pelo governo federal em 2011, destinado à formação das professoras que possuíam instrução a nível médio. No estado de Minas Gerais, houve a ação do Programa Veredas, nessa mesma época, enfocando a Educação Infantil também nos anos iniciais de Pedagogia.

Nunes, Corsino e Didonet (2011) observam que a maior parte das matrículas em creches está a cargo das redes municipais de ensino, que abrangem em média de 65,2\%, seguidas por $34 \%$ de matrículas nas redes privadas. Dentre todas as etapas da educação básica, está na creche a maior participação da rede privada. A relação público/privado é um traço ainda forte no tocante às creches. Atualmente, muitas instituições desses ramos mantêm convênios com a esfera pública, atendendo grande parte das crianças, assim como se observa em Juiz de Fora (MG), que, no momento, conta com convênios, em sua maioria, com instituições confessionais ou filantrópicas. Ainda de acordo com as mesmas autoras, muitas creches brasileiras contam com parte significativa de seus profissionais - inclusive docentes constituída de terceirizados, vinculados a organizações sociais ou organizações não governamentais, que recebem verbas públicas para realizar a prestação dos serviços.

Tem-se consolidado, no âmbito das políticas educacionais, desde o ano de 2011, o regime de colaboração entre os entes federados, cujo objetivo é o combate às desigualdades educacionais. Essa ação vem se materializando por meio do Plano de Ações Articuladas dos Municípios (PAR) que, a partir de uma avaliação diagnóstica da realidade educacional local, permite que o município trace um plano de metas que enfrentem tais desigualdades. Vinculado ao Plano de Desenvolvimento da Educação Básica (PDE), o PAR busca enfrentar 
estruturalmente as desigualdades de oportunidades educacionais na perspectiva de reduzir desigualdades sociais e regionais. Assim sendo, Nunes, Corsino e Didonet (2011) são enfáticos em apontar a fundamentalidade da visibilidade da Educação Infantil nas avaliações diagnósticas municipais,para que, ao serem mapeadas as necessidades da Educação, seja possível atingir a visão sistêmica da educação básica postulada pelo PDE. Do modo como as demandas, metas, ações e oferta de programas por parte do MEC se conjugam, a função colaborativa vai se transversalizando, e a maior consequência disso são a exigência de parcerias, a maior responsabilização dos entes federados e o compromisso entre o PAR, as metas do PDE e a oferta de projetos e programas do MEC, no exercício de sua função colaborativa, no que constituem mais alguns desafios a uma Educação Infantil de qualidade.

Os novos marcos legais amealhados nos dois últimos anos (2009-2010) pela educação infantil trazem com eles consequências e desafios. É oportuno o momento de mudanças; mas não se pode perder de vista que rompimentos e criações se fazem com disputas, resistências, desvios, e que, nas políticas, o que está em jogo são os projetos de sujeito e de sociedade (NUNES, CORSINO, DIDONET, 2011, p.90).

A integração da Educação Infantil aos sistemas de ensino impulsionou a elaboração e a revisão das propostas curriculares municipais. Observa-se um movimento das secretarias municipais de educação na produção de instrumentos para subsidiar creches e escolas na elaboração dos seus projetos político-pedagógicos, o que será debatido no próximo tópico do capítulo. Outro movimento atual é a construção da Base Curricular Nacional Comum (BNCC), prevista na Constituição de 1988, no Plano Nacional de Educação e na LDB, que prescreve em seu $26^{\circ}$ artigo que:

Os currículos da educação infantil, do ensino fundamental e do ensino médio devem ter base nacional comum, a ser complementada, em cada sistema de ensino e em cada estabelecimento escolar, por uma parte diversificada, exigida pelas características regionais e locais da sociedade, da cultura, da economia e dos educandos. (BRASIL, 1996, art.26).

Essa prescrição conduz à compreensão central da BNNC, no capítulo que compete à Educação Infantil: o "conhecimento curricular contextualizado pela realidade local, social e individual da escola e do seu alunado", fundamento pautado pelas Diretrizes Curriculares Nacionais da Educação Infantil. O documento em tela expressa que "as competências e diretrizes são comuns e os currículos são diversos", tentando romper com a aprendizagem de conteúdos mínimos. 
Sobre o notável e gradual crescimento da Educação Infantil brasileira, ainda que os percentuais de frequência sejam crescentes, há uma distância entre o que prescreve a meta $1^{59}$, estipulada pelo Plano Nacional de Educação ${ }^{60}$ (PNE), e a satisfação das necessidades sociais. Em recentes dados divulgados pelo INEP (Instituto Nacional de Estudos e Pesquisas Educacionais Anísio Teixeira) e Censo Escolar, sintetizados pela PNAD Contínua, compreendendo o período 2016-2017 ${ }^{61}$, o percentual de crianças de 0 a 3 anos que frequentaram creches no Brasil atingiu a média de 34,1\%. Desse montante, $26 \%$ das crianças que frequentaram creches se encaixavam no recorte do quinto de renda mais pobre, contra $55 \%$ de crianças do recorte do quinto mais rico da população. Tais informações confirmam as análises de Rosemberg (1999), Nunes, Corsino e Didonet (2011), no que compete ao desigual acesso às creches em todas as regiões do país, bem como aquelas que residem em área urbana, quando comparadas àquelas que residem nas áreas rurais. Persistem ainda as desigualdades de acesso de crianças negras às brancas, e entre brancas e pardas, bem como as de famílias mais humildes ante as de famílias ricas.

O INEP estima que a população de idade entre 0 e 6 anos gira em torno de 20 milhões. Aproximadamente 1,5 milhão de crianças e jovens não frequentavam a escola em 2017, dos quais 370.410 eram crianças de 4 e 5 anos. A pesquisa não menciona como essa situação afeta a faixa etária de 0 a 3 anos, o que já é um indício da não-obrigatoriedade. Na faixa etária dos 4 e 5 anos, a situação é bem melhor. A média nacional de frequência atinge o percentual de 93\%. Tomando como referência o recorte populacional mais pobre, 91,3\% das crianças frequentaram a pré-escola, enquanto que $96,1 \%$ das crianças pertencentes às classes altas frequentaram o mesmo nível de ensino. No ano de 2018 , estima-se que $71,6 \%$ dessas matrículas foram atendidas pela rede pública, totalizando um público de 8,7 milhões ${ }^{62}$. Conforme as regiões, as matrículas atingem os seguintes patamares no ano de 2017:

\footnotetext{
${ }^{59}$ Universalizar, até 2016, a educação infantil na pré-escola para as crianças de 4 (quatro) a 5 (cinco) anos de idade e ampliar a oferta de educação infantil em creches de forma a atender, no mínimo, $50 \%$ (cinquenta por cento) das crianças de até 3 (três) anos até o final da vigência deste PNE (BRASIL, 2014).

${ }^{60}$ Lei 13.005 do ano de 2014. A vigência do Plano compreende o período do ano de 2014 até o ano de 2020.

61 Fonte: http://estatico.redeglobo.globo.com/2019/11/06/infancia_em_dados.pdf Acesso em 06/02/2020.

${ }^{62}$ Fonte: http://estatico.redeglobo.globo.com/2019/11/06/infancia_em_dados.pdf. Acesso em $06 / 02 / 2020$.
} 
Quadro 3. 1: Comparativo de creches e pré-escolas por região.

\begin{tabular}{|l|l|l|}
\hline REGIÃO & CRECHES & PRÉ-ESCOLAS \\
\hline Norte & $18,3 \%$ & $86,7 \%$ \\
\hline Nordeste & $30,6 \%$ & $95,6 \%$ \\
\hline Sudeste & $40,4 \%$ & $94,5 \%$ \\
\hline Centro-Oeste & $26,9 \%$ & $88,6 \%$ \\
\hline Sul & $40,9 \%$ & $90,4 \%$ \\
\hline
\end{tabular}

Fonte: Organizado pela autora a partir de dados do IBGE/PNAD Contínua/INEP.

Mesmo praticamente se atingindo a universalização do acesso das crianças de 4 e 5 anos, o acesso das crianças de faixa etária de 0 a 3 anos ainda se arrasta. Mesmo apresentando dados que indicam os avanços na área da Educação, muitas desigualdades que afetam as crianças ainda precisam ser superadas para que possamos dizer que cumprimos integralmente com a obrigação de protegê-las, resguardá-las e garantir que os seus direitos sejam cumpridos, como as desigualdades raciais.

As crianças pretas e pardas superam as brancas, justamente nas regiões economicamente menos desenvolvidas: na zona rural para o conjunto de desenvolvimento nacional; nas regiões Norte, Nordeste e Centro-Oeste. Associando-se densidade populacional e composição racial, observa-se que as crianças brancas residem no Sudeste $(70,4 \%)$ e as não brancas no Nordeste $(49,8 \%)$. Desse modo, foram principalmente as crianças pretas e pardas que se defrontaram com o modelo de educação não formal introduzido no início da década de oitenta o que acarretou impacto racial no impacto do usuário dos diferentes programas oferecidos (ROSEMBERG, 1999, p.25).

Recentemente, o Observatório da Criança e do Adolescente ${ }^{63}$ divulgou que, das 3.651.989 crianças matriculadas nas creches no ano de 2020 no Brasil, 108.424 são crianças negras, outras 1.357.361 são brancas, enquanto 1.066.986 são pardas. Outras 10.481 são indígenas, e 10.266 são declaradas amarelas. Tais números precisariam ser analisados mais precisamente à luz de outros indicadores sociais, mas ao indicar uma expressiva maioria de crianças brancas tendo acesso à Educação desde a pequena infância, fíca explícita a importância de maiores debates sobre as questões raciais no Brasil e na Educação Infantil. Por essas reflexões sobre o teor as creches e pré-escolas, nas tendências e fatores de influência nas

\footnotetext{
${ }^{63}$ Fonte: https://observatoriocrianca.org.br/cenario-infancia/temas/educacao-infantil/679-numero-dematriculas-em-creches-segundo-cor-raca?filters $=1,902$. Acesso em 15/02/2021.
} 
construções das políticas voltadas à Educação Infantil de modo geral no Brasil, o próximo tópico dá a conhecer sobre essas construções no município de Juiz de Fora (MG).

\subsection{EDUCANDO CRIANÇAS PEQUENAS EM JUIZ DE FORA (MG)}

Esse tópico caracteriza a localidade de Juiz de Fora (MG), apresentando seus aspectos gerais, bem como o panorama da Educação Infantil nesse município, utilizando como fontes teses e dissertações produzidas na municipalidade, abordando as principais discussões em torno desse nível de ensino.

Juiz de Fora é um município localizado no estado de Minas Gerais, em uma região geográfica conhecida como Zona da Mata. A cidade foi fundada no século XVIII, no período da mineração do ouro, às margens da estrada Caminho Novo, a partir de um povoado conhecido como Santo Antônio do Paraibuna, fundado em 1850, dentre outros que serviam como pontos de registros e físcalização de mercadorias. Segundo o levantamento histórico produzido na tese da professora Alesandra Maia Lima Alves (2016), a cidade, já batizada com o nome de Juiz de Fora ${ }^{64}$, foi pioneira no ramo da indústria, ocasionando a elevação de município mais importante do estado, e a fama de "Manchester Mineira" e "Princesa de Minas". Tendo como atividade principal a cafeicultura, Juiz de Fora sofre sérios abalos econômicos com a Crise de 1929, só retomando seu crescimento na década de 1960. A partir da citada crise global, a economia de Juiz de Fora, bem como seu desenvolvimento, sofreu uma retração sentida mais fortemente nos anos de 1940, "em virtude da incapacidade de atrair novos mercados e pela perda de parte de seus mercados tradicionais" (ALVES, 2016, p.91).

Juiz de Fora é uma das cidades brasileiras com melhores índices de qualidade de vida e um dos principais polos industriais, culturais e universitários do estado de Minas Gerais. Conforme dados divulgados pelo IBGE em 2010, a população somava 516.247 habitantes e apresenta Índice de Desenvolvimento Humano (IDHM) de 0,778, considerado alto para os parâmetros de desenvolvimento que englobam a área da saúde, da educação e renda. Atualmente, a cidade de Juiz de Fora se subdivide em 111 bairros, além dos distritos de Torreões, Rosário de Minas e Sarandira, ocupando uma área territorial de $1429,875 \mathrm{~km}^{2}$.

\footnotetext{
${ }^{64} \mathrm{O}$ nome de Juiz de Fora surge a partir da vinda de um juiz -vindo de fora- nomeado pela Coroa de Portugal, para atuar na região, que não possuía um juiz de direito. A história conta que esse juiz residia em uma fazenda próxima ao povoado de Santo Antonio do Paraibuna, em local que ficou conhecido como Sesmaria do juiz de fora. Fonte: https://pt.wikipedia.org/wiki/Hist $\%$ C3\%B3ria_de_Juiz_de_Fora Acesso em 28/04/2020.
} 
Ainda hoje exerce influência sobre outros municípios da região da Zona da Mata, Sul de Minas Gerais e cidades do interior fluminense, pela proximidade geográfica.

Figura 3. 2: Delimitação do município de Juiz de Fora (MG)

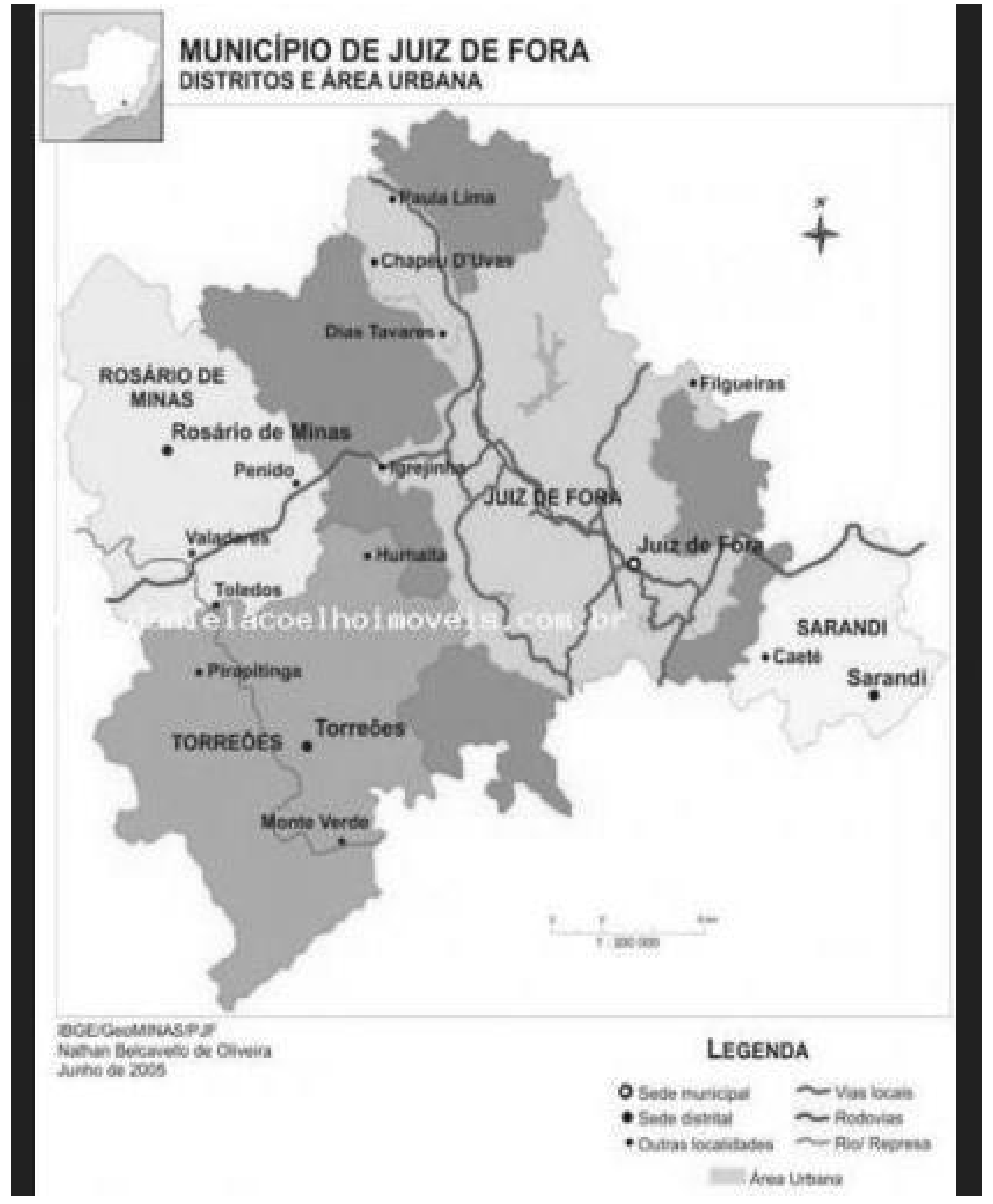

Créditos: na própria imagem. 
A tese de Alves (2016) apura que a retomada do desenvolvimento econômico e industrial de Juiz de Fora (MG) ocorreu durante o período da Ditadura Militar. Para que fosse possível a promoção da retomada da industrialização, os políticos da cidade se empenharam em atrair recursos por meio do investimento em infraestrutura urbana básica. Entretanto, a autora nos alerta que tais mudanças não corresponderam ao fim dos problemas sociais. Os políticos locais, nesse período, empenharam-se em promover o seu poderio industrial, atraindo investimentos e diminuindo problemas sociais através de investimento em infraestrutura urbana básica. No entanto, a mão de obra imigrante continuava a ser explorada e remunerada com salários ínfimos, ao lado da população negra e livre não incorporada ao mercado de trabalho. Havia índices consideráveis de pessoas pobres e miseráveis, além de altos índices de evasão e repetência escolares, e pouca disponibilidade de vagas em escolas públicas. Juntamente com as condições sociais deficitárias, as condições de higiene e limpeza urbanas também eram precárias, condições presentes até a década de 1990, acompanhando os períodos de recessão econômica observados no país como um todo.

É a partir da década de 1990 que Juiz de Fora retoma o seu crescimento e desenvolvimento, notadamente pelas reformas urbanas, em que serviços como o calçamento de ruas, saneamento, recenseamento da população, tão necessários para o desenvolvimento da indústria e do comércio foram sendo desenvolvidos. No caso da Educação, investiu-se em também na construção de escolas, creches, ampliando o número de vagas. É nesse contexto de carências sociais, comuns ao Brasil e demais países da América Latina, como já debatido no capítulo 2, que emerge a história da constituição das creches no município de Juiz de Fora (MG). Outra similaridade dessa história no citado município reside na contribuição de ações de mobilização e organização populares, constituindo um movimento participativo junto aos órgãos de governo, a ser exposto no decorrer do capítulo.

Para melhor compreensão do contexto em questão, outra tese de doutorado, intitulada O processo de transição das creches da Assistência Social para a Educação em Juiz de Fora/MG (2008-2013), da professora brasileira Alexsandra Zanetti (2015) nos expõe os principais movimentos da localidade em torno das creches. O movimento inicial local ocorreu na década de 1980, com a formação do Grupo Pró-Creche. Esse grupo nasce com o objetivo de mobilizar a comunidade para as questões da criança carente, discutindo sobre a criação e a contribuição social acerca das creches comunitárias. Esse movimento inicia um convencimento da população sobre a necessidade de abertura de creches, assim como a captação de recursos necessários para essa ação. 
Com relação às categorias profissionais de atendimento às crianças pequenas, Nunes, Corsino e Didonet (2011) dissertam sobre a existência de dois perfis de profissionais que atuam nos dois ramos da Educação Infantil. As pré-escolas geralmente funcionam em meio período e as creches em período integral. Também há distinções relacionadas ao nome atribuído a estas trabalhadoras: "professoras para as pré-escolas, pajem, crecheiras, monitora, auxiliar de desenvolvimento infantil etc., para as creches”. No caso de Juiz de Fora, a situação não se apresentava diferente. De fato, as participantes da pesquisa de campo utilizaram apenas uma vez o termo "professora" ao longo dos seis encontros formativos. A denominação mais utilizada foi a de "educadoras". Tal diferença de nomenclatura também é notada nos planos de carreira, condições de trabalho e vencimentos. As primeiras fazem parte do quadro de trabalho do magistério da Prefeitura de Juiz de Fora, com um plano de carreira estabelecido, enquanto que as segundas são contratadas, com vínculo empregatício pela Consolidação das Leis Trabalhistas (CLT), pela Associação Municipal de Apoio Comunitário (AMAC), um órgão de assistência social.

Ao discorrer sobre a natureza empregatícia das profissionais pertencentes à AMAC no município de Juiz de Fora (MG), Maia (2016) descortina mais uma "das questões que expressam a dualidade na Educação Infantil no Município". Por ser instituição que esteve até recentemente à frente dos serviços de creches em Juiz de Fora (MG), as ações da AMAC serão melhor exploradas em item em separado, nos próximos momentos da tese.

Nunes, Corsino e Didonet (2011) são enfáticas em afirmar que suprir a demanda pela Educação Infantil é cumprir um dever do Estado, assim como defendido na presente tese, diante de um direito da criança e de uma opção dos pais.

A proteção dos direitos sociais, perante as desigualdades brasileiras, tem
exigido a presença do Estado e o controle da sociedade civil organizada na
adoção de políticas públicas adequadas para o seu efetivo cumprimento. Esta
lição tem como sustentáculo a concepção de que as crianças são seres sociais
ativos, produtores de cultura e, ao mesmo tempo, por ela produzidos, sujeitos
de direitos, cidadãos em processo, cujo desenvolvimento se dá de forma
integral nos aspectos físicos, sociais, emocionais e cognitivos (NUNES;
CORSINO; DIDONET, 2011, p.74).

Logo, a construção de políticas públicas para a Educação tem-se efetivado por meio de debates com toda a sociedade, especialmente nas instituições acadêmicas e nas diversas entidades que demandam ações em torno do direito à educação pública e de qualidade para todos os brasileiros (NUNES; CORSINO; DIDONET, 2011, p.80). Tal movimento, em termos de compartilhamento das preocupações com a Educação Infantil pela sociedade e 
outros entes além das mulheres-mães, o que indica uma dissociação passível de ser pensada e alinhada ao pressuposto da maternagem, que é a incumbência para com a Educação e o cuidado para além da gestação (MEYER, 2011).

Os municípios não alcançam o objetivo de construir políticas públicas isoladamente, principalmente com relação ao público da faixa etária de 0 a 3 anos. No caso de Juiz de Fora (MG), que no início do século XX não dispunha nem de condições de infraestrutura satisfatória, também não existiam instituições municipais que atendessem as crianças pequenas. O primeiro jardim de infância do município foi fundado na década de 1920 . O Jardim de Infância Mariano Procópio foi a instituição pioneira da região, surgindo por iniciativa do Governo Estadual. Além dessa iniciativa, Alves (2016) a partir de compilado de jornais e documentos municipais da época, relata que surgem outras ações voltadas às crianças pequenas, realizadas por instituições assistenciais e filantrópicas, tais como as ações de acolhimento da Santa Casa de Misericórdia, e o trabalho da Associação de Damas Protetoras da Infância, (ADPI), também conhecida como Lactário São José. Essa organização foi criada em 1934, por pediatras da cidade de Juiz de Fora (MG), com a finalidade de combater a mortalidade e desnutrição infantis.

Logo em seguida, as atividades da ADPI passaram a ser administradas pelas damas, do que era percebido na localidade como alta sociedade juiz-forana, o que nos remete a um sentido diferente das associações de mulheres descritas nos capítulos 1 e 2. Diferentemente dos movimentos de bairros e associações comunitárias de mulheres das classes mais pobres, cujo intuito de reivindicar direitos e buscar soluções para problemas de infraestrutura e outras necessidades, o propósito de mobilização de mulheres das classes mais altas ocorria por conta de interesses políticos, em uma prática conhecida como primeiro-damismo, foco do texto $O$ primeiro damismo na assistência social: uma análise crítica (2019), escrito pelas psicólogas brasileiras Camilla Lopes e Fabiana Grossi.

Conforme o citado texto de Lopes e Grossi (2019), o primeiro damismo remete às atividades de caridade, exercidas pelas mulheres denominadas Primeiras Damas, atuando como coadjuvantes em contribuir à uma boa imagem dos trabalhos que seus maridos desenvolviam junto à sociedade. Ainda que com propósitos distintos, as diferenças de classe não bastavam para que essas mulheres ricas exercessem outras ocupações além dos cuidados com as pessoas, o que torna possível vislumbrar a extensão dos trabalhos domésticos, de esfera privada, também na esfera pública, materializando as análises de Joan Scott (1997) sobre o gênero. Este quando relacionado à classe social, e também como classe enquanto 
grupo, permite que apreendamos, em perspectiva feminista interseccional, que todas as mulheres, mesmo em diferentes graus, a depender de suas especificidades, sejam socialmente inferiorizadas.

Em Juiz de Fora (MG), a Escola Infantil Amélia Pires, fundada no ano de 1966, é a primeira escola pública municipal a atender as crianças de até 7 anos. No ano seguinte foi fundada a Escola Infantil São Tarcísio, no bairro Nossa Senhora Aparecida. Tais escolas configuraram uma exceção para o período, pois a real expansão das escolas municipais de educação pré-escolar ocorreu em Juiz de Fora nas décadas de 1970 e 1980. Sobre as condições de vida dos alunos e alunas, tanto na zona rural quanto na urbana, Alves (2016) pontua que "se caracterizavam como precárias, pois, em sua maioria, eram filhos de uma população de baixo poder aquisitivo", uma vez que um terço da população possuía renda de até 3 salários mínimos. Isso consiste em um dado que corrobora a atenção às categorias sociais privilegiadas na presente tese, já que essa se baseia em construção de cunho higienista debatida por Kulmann Jr. (1998), que associava a pobreza às mazelas sociais, de maneira irrefletida, sem se ponderar sobre as origens dos problemas sociais que acometiam a população, como o acesso à Educação e a precariedade do alcance de políticas de empregos, responsabilidades do poder governamental.

Ao lado disso, a década de 1970 foi marcada pela já mencionada campanha nacional para combate ao analfabetismo (MOBRAL), que se destinava a recobrir a demanda de um público em torno de 30 milhões de brasileiros. Juiz de Fora (MG) aderiu a esse movimento e juntamente com os governos federal e estadual, passou a investir mais no setor da Educação. O município promoveu a ampliação do número de instituições escolares, e investiu na oferta e incentivo da participação dos docentes em cursos de formação. Os investimentos e recursos eram provenientes do Ministério da Educação e Cultura, que desenvolveu o Projeto PróMunicípio. Tal projeto foi concebido a partir das orientações do Banco Mundial, cuja principal diretriz era a associação da Educação como vetor de desenvolvimento. Mesmo que a principal intenção do Projeto fosse promover, de acordo com Alves (2016) "a municipalização do ensino de $1^{\circ}$ grau", a captação de recursos sem dúvida favoreceu a abertura de classes pré-escolares e a construção de escolas municipais infantis, o que, em certa medida, indica um processo de democratização da Educação Infantil, até então praticamente nula no município.

Assim, Juiz de Fora iniciou na década de 1980 as obras das Escolas Municipais de Educação Infantil, com instalação da rede física específica e equipamentos próprios, o que 
caracterizou uma nova era para o atendimento municipal infantil. Concomitantemente, Juiz de Fora tinha a necessidade de melhorar a qualidade das séries iniciais, que apresentava altos índices de evasão e reprovação. Para modificar esse cenário, a Educação Infantil foi considerada como necessária. Diante disso, Alves (2016) aponta que houve a aprovação da realização do Projeto Especial Educação Pré-Escolar, que destinava financiamento para a edificação de 12 Escolas Municipais de Educação Infantil, primeira ação de grande porte no município.

Acompanhando a tendência nacional, no final da década de 1970 e início da década de 1980, o pré-escolar de Juiz de Fora se concretizou pela ação do Programa de Atendimento e Promoção ao Pré-Escolar (PAPPE). Esse programa, que resultou de um convênio entre a Prefeitura de Juiz de Fora e a Legião Brasileira de Assistência (LBA), que, em 1977, objetivava atender à faixa etária de 2 (dois) a 6 (seis) anos de idade. Segundo Alves (2016), cabia à Prefeitura arcar com os recursos humanos competentes, enquanto a LBA era responsável pelas verbas destinadas à alimentação e à compra dos materiais fornecidos às crianças, como brinquedos, materiais escolares, roupas e calçados.

Com o passar do tempo, os PAPPEs passaram a ser denominados como Escolas Municipais de Educação Infantil (EMEI), fazendo-se apenas algumas reformas nas edificações. Outro programa atrelado às EMEIs foi o Programa de Alimentação Escolar (PAE), que se voltava a garantir o desenvolvimento das crianças combatendo a desnutrição. $\mathrm{O}$ primeiro PAPPE foi construído no bairro São Benedito, expandindo-se após à outros bairros considerados carentes, como Dom Bosco, Furtado de Menezes, Jóquei Clube, Linhares, Nossa Senhora Aparecida, Ipiranga e São Pedro, seguidas da construção de unidades nos bairros Progresso, Ipiranga, Borboleta, Cerâmica e Marumbi. Os PAPPEs juiz-foranos chegaram a atender a atender, ao final do ano de 1981, cerca de 1300 crianças (ALVES, 2016).

Ainda distante de cobrir a demanda por creches, no citado período, Juiz de Fora (MG) priorizava a importância da alimentação. No final da década de 1970, Alves (2016) nos relata que o PAPPE distribuía três refeições diárias para as crianças no período de férias, principalmente para alunos carentes que frequentavam o pré-escolar, no que resultou na promoção de eventos tais como a Semana da Alimentação, a Semana da Cantineira e a Semana da Comunidade.

Ainda segundo Alves (2016) Juiz de Fora também contou com as ações do Programa Especial de Pediatria (PEP), que defendia campanhas preventivas em benefício da criança brasileira. Como já mencionado anteriormente na tese, o olhar prestigioso às crianças 
pequenas e à Educação infantil por meio de políticas públicas ocorreu por conta da instituição do Ano Internacional da Criança (AIC) em 1979. A situação das crianças pobres, vivendo em condições sub-humanas em todo o mundo, não se mostrava distante da realidade das crianças brasileiras, tampouco das crianças pobres de Juiz de Fora (MG), com um número considerável de crianças e adolescentes vivendo em situação de risco ou vulnerabilidade. Juiz de Fora adotou a perspectiva da importância da Educação Infantil, mas esse movimento se ligou muito mais ao empreendimento de combate aos problemas sociais, de abandono e de sanar os problemas do Ensino Fundamental, do que propriamente valorizar a educação e o potencial da pequena infância. Nas assertivas palavras de Alves (2016), “a valorização da educação infantil advém do olhar assistencial, do salvacionismo e indica a ideia da privação cultural".

Ainda por influência do Ano Internacional da Criança (AIC) e Ano I da Criança Brasileira, outros setores também se movimentaram em ações à esses marcos. A programação local contou com iniciativas como o evento "A Enfermagem e as Crianças na Realidade Brasileira", as ações da Legião Brasileira da Assistência e a instalação de um comitê da Organização Mundial de Educação Pré-Escolar - (OMEP) em Juiz de Fora. O citado evento realizou atividades ligadas à prestação de assistência às crianças, contando com a participação da Faculdade de Enfermagem da Universidade Federal de Juiz de Fora (ALVES, 2016) e contou com cerca de 50 profissionais da área. Ainda que com palestras e proposituras de ações práticas, Alves (2016) observa que essa iniciativa pouco contribuiu com a mudança na realidade das crianças, por terem sido episódios pontuais, e por se concentrarem, sobretudo, na área do lazer.

Ainda de acordo com a tese de Alves (2016), o convênio da prefeitura de Juiz de Fora com a Legião Brasileira de Assistência teve início no ano de 1975. As creches-casulo tinham o objetivo de proporcionar atendimento integral às crianças menores de 7 anos com poucos recursos, oferecendo repasses financeiros para tal. No entanto, as unidades das creches do projeto casulo contavam com o trabalho voluntário, o que denota a precariedade das políticas voltadas às crianças. A meta da LBA era, na década de 1980, atender a 1 milhão de crianças nas creches casulo. Para se atingir esse objetivo, o Programa conclamava à todas as instituições - secretarias estaduais e municipais de educação, empresas e comunidade- para analisarem as possibilidades de atendimento em termos de infraestrutura física., o que é retrato conhecido da Educação Infantil brasileira e em toda gama de políticas "para os pobres". 
Sobre a educação pré-escolar, Juiz de Fora (MG) também segue acompanhando as tendências nacionais, fundando no ano de 1979 o comitê da Organização Mundial de Educação Pré-Escolar (OMEP), também acompanhando as atividades do Ano Internacional da Criança. Uma ação de destaque da OMEP no município foi a criação de uma creche para filhas/os de empregadas domésticas no ano de 1980. A unidade vinculava-se ao Projeto Casulo, logo mantida pela LBA, funcionando em tempo integral (ALVES, 2016). A OMEP também atuava na formação de profissionais para atuarem com segmento pré-escolar, e contava, para se manter, com o auxílio e apoio de pessoas, entidades e voluntários.

Como já mencionado, o atendimento à infância em Juiz de Fora foi impulsionado pelo Movimento Brasileiro de Alfabetização (MOBRAL). Cerca de 70 mil crianças foram incorporadas ao programa de atendimento às crianças de 4 a 6 anos que o MOBRAL vinha realizando entre a população de baixa renda, junto à instituições que atuavam na área social e com apoio da comunidade, principalmente pais e mães. Esse programa nacional foi responsável por implantar 60 unidades de educação pré-escolar, que atendiam a 1562 alunos nos Núcleos de Desenvolvimento da Infância (NDI), além de oferecer cursos profissionalizantes. Conforme a tese de Alves (2016), o MOBRAL trabalhava em conjunto com a Campanha Nacional de Alimentação Escolar (CNAE), cuja parceria garantia a merenda escolar para as crianças que participassem do Programa na cidade de Juiz de Fora (MG).

Em 1985, após a extinção do MOBRAL, criou-se a Fundação Educar (Fundação Nacional de Educação de Jovens e Adultos). Na ocasião, a população ficou receosa com a interrupção dos serviços, especialmente com relação à educação pré-escolar. Alves (2016) nos conta que as famílias das crianças atendidas nos NDIs - em 60 postos de atendimento reivindicaram que houvesse a continuidade das ações educacionais. Por força de reinvindicação popular, foi mantido o convênio com a Prefeitura Municipal, com algumas mudanças, e também manutenções. Com a criação das EMEIs, as crianças que frequentavam os NDIs foram sendo absorvidas. Em relação aos recursos, a Fundação Educar continuaria a se comprometer com a contratação de professoras/es e monitoras/es do Pré-escolar, mas seguia incentivando a participação voluntária da população. Sobre essa informação, Alves (2016) nos detalha que:

Uma das cláusulas do convênio firmado dizia que, caso os profissionais não tivessem habilitação necessária, poderiam ser contratados educadores sem a formação específica, que teriam o prazo máximo de 4 anos para se habilitar. Essa cláusula confirma que eram admitidos professores sem formação necessária, o que caracterizava um atendimento pré-escolar emergencial e 
com práticas assistenciais. A Prefeitura de Juiz de Fora não poderia, por questão de princípio e, consequentemente, por sua legislação, que determinava que o ingresso na carreira de Magistério só seria feito por exame de seleção, com professores habilitados, comprometer-se com o aproveitamento de todas as ex-monitoras das salas de pré-escolar do antigo MOBRAL. O caráter de voluntariado, com remuneração simbólica, em unidades escolares, contrariava as disposições político-administrativas da época. Outro fator a se destacar diz respeito à manutenção das salas de aulas de pré-escolar nos locais (Núcleos de Desenvolvimento Infantil) em que vinham funcionando, o que implicava atacar condições qualitativamente inferiores aos mínimos estabelecidos pela legislação e compatíveis com o respeito aos direitos das crianças (ALVES, 2016, p.109).

Ao lado disso, outra questão importante é apontada por Alves (2016): o impasse municipal, que de um lado era pressionado pela comunidade para que mantivesse o atendimento às crianças e, de outro, o curto orçamento da Secretaria Municipal de Educação, que não dispunha de meios de arcar com a demanda dos postos de pré-escolar da cidade. De acordo com Alves (2016), a Secretaria de Educação elaborou, em 1986, uma proposta que registrou as modificações necessárias, tanto do ponto de vista financeiro quanto do ponto de vista da concepção dos serviços voltados para as crianças pequenas. No entanto, a proposta ainda estava distante de oferecer concretamente uma educação de qualidade para os pequenos, uma vez que ainda se pautava como um serviço, e não como um direito das crianças. Logo, a Prefeitura, segundo Alves (2016), ao admitir que não dispunha de condições de arcar com o compromisso dos encargos do pré-escolar, frente à demanda do Ensino Fundamental -etapa obrigatória- situou a importância do apoio financeiro do MEC.

Apesar de as EMEIs terem contribuído de forma ímpar à educação das crianças no município, elas não foram suficientes para atender à toda a população. Assim nasce as redes de convênios voltadas às escolas infantis.

Tal crescimento se deu devido às pressões da sociedade civil, à saída da mulher para o mercado de trabalho, ao reconhecimento legal da Educação Infantil como direito da infância, as discussões políticas da necessidade dessa etapa educacional e de que não havia mais como continuar negando a necessidade dessa etapa de ensino para o desenvolvimento integral das crianças pequenas. Parte desse atendimento era feito através da Associação Municipal de Apoio Comunitário (AMAC).

\subsection{AMAC: UM CAPÍTULO IMPORTANTE NA EDUCAÇÃO INFANTIL DE JUIZ DE FORA (MG)}


Como explicitado em item anterior, o poder público de Juiz de Fora (MG) vinha caminhando no processo de municipalização da educação das crianças pequenas desde a década de 1980, com a criação das Escolas Municipais de Educação Infantil e com as iniciativas das Creches Comunitárias. Tal movimento veio crescendo, em meio a conhecidos, e também novos desafios. A Associação Municipal de Apoio Comunitário (AMAC) teve atuação importante e longeva na seara das creches em Juiz de Fora, atuando do ano de 1985 até o ano de 2019, cuja trajetória será recuperada nesse item.

A regulamentação da Educação Infantil como primeira etapa da Educação Básica, através da Lei de Diretrizes e Bases da Educação Nacional, no ano de 1996, é reconhecido em toda a produção teórica acessada (NUNES; CORSINO; DIDONET, 2011; ALVES, 2016; ZANETTI, 2015) como o grande marco de um projeto de sociedade que confere a legitimidade do reconhecimento do direito à Educação, pelas cidadãs crianças. Significa uma mudança profunda, de não somente uma transferência de responsabilidade de setores assistenciais à Educação, mas de uma mudança de compromisso nas múltiplas dimensões de desenvolvimento infantil. Isso implica, conforme as palavras de Zanetti (2015) em efetivar mudanças relacionadas à expansão do atendimento, das regulamentações, da proposta pedagógica, dos currículos, do financiamento, da infraestrutura, padrões de qualidade e formação de professoras/es. Todo o Brasil, e também Juiz de Fora (MG), passa a ter de lidar concretamente com a responsabilização legal por esse nível de ensino. Além disso, a Educação Infantil passa a ser obrigatoriamente, da alçada da Educação. Como já explicitado em outros momentos, o atendimento às crianças pequenas se dava no âmbito da área social, especialmente aquelas de faixa etária entre 0 e 3 anos. Na cidade de Juiz de Fora (MG) essa é era competência da Associação Municipal de Apoio Comunitário (AMAC).

A AMAC foi fundada em 8 de janeiro do ano de 1985. No entanto, Alves (2016) nos elucida que a instituição foi criada a partir da Lei de $n^{0} 6.624 / 1984^{65}$. A citada Lei municipal, explicita em $1^{\circ}$ parágrafo que "é o Município de Juiz de Fora autorizado a contratar, com as pessoas indicadas no artigo $3 .^{\circ}$, a constituição de associação civil, com personalidade jurídica de direito privado, sem finalidade lucrativa e do prazo indeterminado, desde que observado o que dispõe esta Lei” (JUIZ DE FORA, 1984). Em seguida, a mesma Lei, agora no segundo artigo, inciso 5, que versa sobre as finalidades da associação estabelece a permissão de

${ }^{65}$ LEI N. ${ }^{\circ} 6624$ - de $1^{\circ}$ de novembro de 1984. Autoriza o Município de Juiz de Fora a contratar, com as pessoas que menciona a constituição de associação civil e dá outras providências [...] Parágrafo Único - A associação a que se refere o artigo, denominar-se-á Associação de Apoio Comunitário (AMAC).

Disponível em https://jflegis.pjf.mg.gov.br/norma.php?chave=0000018638 
“captar recursos públicos e privados com vistas à consecução dos seus objetivos" (JUIZ DE FORA, 1984), tendo em vista que a presidência é exercida pelo prefeito do município, ao lado de sócios "fundadores contribuintes",66 "contribuinte", "honorários" e "beneméritos" (JUIZ DE FORA, 1984, art. $5^{\circ}$ ), que também têm suas cotas de disponibilização de recursos. Desta maneira, a AMAC se torna a entidade que exerce "[...] atividades típicas da administração públicas, uma vez que é responsável pelo planejamento e execução da Política de Assistência Social na cidade" (ALVES, 2016, p. 121). A esse respeito, Alves (2016) completa:

Essa instituição ficou caracterizada, então, como entidade civil de natureza jurídica privada, sem fins lucrativos, com personalidade jurídica distinta da de seus sócios, os quais não respondem solidária ou subsidiariamente pelas obrigações por ela contraídas. A AMAC, nesse sentido, ficou responsável pela assistência social pública no Município e voltou-se historicamente para a introdução de mecanismos de apoio às organizações da sociedade civil, e não diretamente à população [...]. (ALVES, 2016, p. 121).

Sobre o contexto político e social da década de 1980 em Juiz de Fora, (MG) período da criação da AMAC, Alves (2016) situa como fundamentais as ações da gestão municipal do período, que organizou as funções da Secretaria de Bem Estar Social. Essa Secretaria focavase em combater problemas relacionados ao abandono, à pobreza e situações de risco social, pela promoção de programas sociais, atendimentos emergenciais em áreas de risco habitacional e de urbanização precária, alimentação, dentre outros, na forma de mutirões de voluntários (ALVES, 2016).

Com os objetivos claramente assistenciais, voltados à população carente, é das ações da AMAC que surge o Programa de Creches na cidade de Juiz de Fora (MG). Alves (2016) rememora que a instituição implantou os Programas Pró-Creche, Pró-Criança, PróAlimentação, Pró-Energia e Pró Habitação. Esses programas se destinavam a aliviar a situação de vulnerabilidade de crianças e de famílias pobres.

Conforme o Catálogo Social do município, a AMAC tinha como público - alvo as crianças, adolescentes e pessoas idosas, e é descrita como entidade que presta acolhimento institucional, assistência pedagógica, psicológica e social, além de oferecer oficinas educativas e de serviços de terapia ocupacional. Possui ações voltadas à treinamento, capacitação e encaminhamento profissional, bem como comercializa produção artesanal,

\footnotetext{
${ }^{66}$ De acordo com o texto da lei 6624/84, os "fundadores contribuintes", além do município de Juiz de Fora são: o Departamento de Água e Esgoto (DAE) do município; a Empresa Municipal de Pavimentação e Urbanização (EMPAV); o Departamento Municipal de Limpeza Urbana (DEMLURB) e a Fundação Cultural Alfredo Ferreira Lage (Funalfa), assim como "pessoas físicas ou jurídicas interessadas" (JUIZ DE FORA, 1984, Art. $3^{\circ}, \S 1^{\circ}$ ).
} 
promove ações de lazer e alimentação e presta assistência à dependentes químicos. Sobre a finalidade específica da AMAC, Alves (2016. p.22) coloca que esta reside em "executar a Política de Assistência Social [...] em consonância com os princípios da Lei Orgânica de Assistência Social, da Norma Operacional Básica e da Política Nacional de Assistência Social".

Sobre o Movimento Pró-Creche, ocorreu no ano de 1983 a implantação do Programa Especial de Creches. Segundo Alves (2016), esse grupo era formado por pessoas interessadas em discutir as questões das crianças carentes e, segundo fontes consultadas pela autora, há registros de políticos e empresários, "o que pode ser uma das raízes das práticas clientelistas que perpassam a história das creches na cidade" (ALVES, 2016, p.123). Tendo em vista os recursos necessários, foram feitos convênios, como o firmado com a LBA (Creches Casulo), e também a promoção de eventos de modo a angariar fundos e doações, como o Mutirão da Criança, o Mercado Pró-Criança, o Primeiro Festival Super Cross e a Festa das Nações ${ }^{67}$. Foram cruciais também a realização de bazares, quermesses e campanhas coordenadas pelas comissões pró-creches dos bairros (ALVES, 2016), o que denota também a mobilização dos atores sociais para a melhoria da realidade do município.

Além disso, a convocação de voluntariado para atuar nas creches fizeram nascer em Juiz de Fora (MG) a figura das Mães de Creches, reforçando de modo precário a figura da mulher como cuidadora e educadora. Sobre esse contexto, Zanetti (2015) nos relembra que ainda não existia uma política de creches, no que constituía ato comum o poder público não se incumbir desse encargo, no que a própria sociedade tomou as primeiras e principais iniciativas no município.

Alves (2016) relata que para se ter acesso à creche comunitária, era preciso que a mãe exercesse atividade laboral. Além disso, era cobrada uma taxa, conforme as condições da família. A mesma autora diz que a administração das creches era composta por um administrador, nutricionista, médico, pedagogo, psicólogo, assistente social, estagiários de serviço social e auxiliar de expediente. Na medida em que o serviço foi se ampliando, acrescentando as disposições contidas na LDBEN, também passou-se a adotar exigências relacionadas à formação inicial, como o curso de Pedagogia ou Magistério. As profissionais da AMAC, como já exposto, possuíam vínculo empregatício distinto das profissionais

${ }^{67}$ Conforme a dissertação de Mestrado de Fernanda Costa (2006), o Mutirão da Criança era uma ação de arrecadação de alimentos e utensílios para as creches. O Mercado Pró-Criança foi o primeiro meio de arrecadação de recursos para as creches, funcionando em local cedido, com a venda de material arrecadado. O Festival Super Cross, assim como a Festa das Nações, eram eventos que convertiam a renda em prol da construção das creches. 
contratadas pela Secretaria de Educação, que ingressavam por meio de concurso. Isso evidenciou, nas palavras de Alves (2016, p.126)," sua vulnerabilidade enquanto instituição" e complicou a incorporação das creches no sistema educacional, uma vez que sua situação jurídica híbrida não a vinculava a nenhuma Secretaria do poder público, o que por sua vez não a responsabilizava por realizar contratações por meio de concurso.

De todo modo, a AMAC seguiu atuando junto à Educação Infantil, em meio a discussões de quem deveria ser responsável pela liderança efetiva da assistência em Juiz de Fora (ALVES, 2016). Ao lado da prescrição da LDBEN da municipalização da Educação Infantil, houve então a criação da Secretaria de Assistência Social, sendo retirada da AMAC a função de gestora da política social.

No que se refere às creches, para atender à disposição do ano de 2008 do Ministério de Desenvolvimento Social, que reforçou a natureza educacional das creches e pré-escolas, Zanetti (2015) assevera que o citado Ministério estabeleceu que, a partir de janeiro de 2009, toda creche e pré-escola que fosse mantida pela área da Assistência Social deveria ser transferida à área da Educação. Isso levou o Ministério Público a propor, no ano de 2009, que o município assinasse um Termo de Ajustamento de Conduta (TAC), para que a entidade fosse extinta, e que se realizassem concursos públicos para os cargos. O município não aderiu ao acordo, o que motivou a impetração de duas Ações Civis Públicas.

Zanetti (2015) analisa que a ação voltada à extinção da AMAC afetava diretamente as creches, pois impedia contratações, conforme afirma a autora:

[...] que a entidade realizasse novas contratações de funcionários até o julgamento final, mesmo que em caráter de substituição, ficando também o município impedido de celebrar novos convênios ou efetuar novos repasses, com exceção daqueles vigentes que poderiam ser prorrogados nas mesmas condições atuais (ZANETTI, 2015, p.103).

Isso levou a Prefeitura de Juiz de Fora, no ano de 2010, a tomar medida emergencial de remanejamento de profissionais das creches municipais às creches comunitárias. De acordo com Zanetti (2015) essa medida foi alvo de duras críticas por parte das profissionais, organizações sindicais e comunidade em geral, pois a interpretação geral era a de que fosse respeitado o caráter público da rede de creches municipais, o que não correspondia ao perfil jurídico da AMAC. Houve a suspensão da liminar que impedia as contratações, e a decisão judicial publicada pela mídia local, em 28 de novembro de 2019, foi a de que a Prefeitura de Juiz de Fora, representantes do Ministério Público do Trabalho (MPT), do Ministério Público 
de Minas Gerais (MPMG) e do Sindicato dos Servidores Públicos de Juiz de Fora (Sinserpu) assinaram o TAC que reconhece a AMAC como uma entidade civil de natureza privada, o que encerra as disputas com a Administração do município. De acordo com o Jornal Tribuna de Minas, o TAC prevê o reaproveitamento dos postos de trabalho, bem como a redistribuição mediante concurso ${ }^{68}$.

\subsection{QUADRO ATUAL DA EDUCAÇÃO INFANTIL JUIZ-FORANA: INSTITUIÇÕES, ACESSO E FORMULAÇÕES EDUCACIONAIS}

Atualmente, Juiz de Fora (MG) conta com uma rede pública de creches e escolas de Educação Infantil que é composta por creches de origem comunitária, conforme já mencionado, escolas infantis municipais e também instituições conveniadas, que têm um perfil congregacional e/ou filantrópico. A Secretaria Municipal de Educação de Juiz de Fora possui o Departamento de Educação Infantil (DEI), bem como é assessorada por Conselhos Municipais, a saber: o Conselho de Alimentação, o Conselho de Educação e o Conselho do Fundeb. No âmbito das políticas educacionais, conta com o Plano Municipal de Educação e com duas propostas de Educação Infantil em vigência.

De acordo com informações divulgadas pela Secretaria de Educação do município, Juiz de Fora possui 28 creches municipais e 46 creches e escolas infantis conveniadas, totalizando 74 instituições ${ }^{69}$. Para acessar uma vaga nas creches, após a realização de uma chamada pública, a pessoa responsável pela criança deve comparecer junto ao Centro de Referência de Assistência Social (CRAS) de sua região domiciliar, portando documentação pessoal e indicação de creche a qual se deseja matricular a criança. A entidade CRAS realiza o cadastro e o encaminha à Secretaria de Educação, que contata a família quando houver a disponibilidade de vaga. A atual seleção das vagas em creches públicas em Juiz de Fora difere da disposição das décadas anteriores, que contemplava as crianças filhas de mães que tivessem vínculo empregatício, como já exposto. A classificação hoje se baseia em critérios ligados à vulnerabilidade social. Em face desse critério, necessária se faz uma observação sobre essa classificação.

Segundo informações do Mapa Social de Juiz de Fora (2012), a Prefeitura de Juiz de Fora adota para a formulação de políticas de vigilância social, com finns ao enfrentamento das

\footnotetext{
${ }^{68}$ Fonte: https://tribunademinas.com.br/noticias/politica/28-11-2019/tac-formaliza-desvinculacaoentre-amac-e-pjf.html. Acesso em 22/01/2020.

${ }^{69}$ Fonte: https://www.pjf.mg.gov.br/secretarias/se/creches/atendimento_creches.php. Acesso em 03/02/2020
} 
situações de vulnerabilidade, o Índice de Desenvolvimento Familiar (IDF), que consiste em amplo diagnóstico socioeconômicos dos domicílios juiz-foranos. Esse Índice se propõe a ser um ponto de partida nas construções políticas sócio assistenciais, adotando o cruzamento de seis dimensões: vulnerabilidade familiar, acesso ao conhecimento, acesso ao trabalho, disponibilidade de recursos, desenvolvimento infantil e condições habitacionais (JUIZ DE FORA, 2012, p. 15). Como dimensões interessantes ao escopo da pesquisa, destacamos o olhar sobre algumas delas.

A dimensão da vulnerabilidade familiar considera indicadores como a presença de mulheres gestantes ou em período de amamentação, crianças, jovens e idosos no núcleo familiar, bem como a dependência econômica, ao pressupor dimensões adicionais de cuidado e educação ou de situação financeira desvantajosa ao considerar que sejam codependentes. Sobre o acesso ao conhecimento, o IDF considera a escolaridade e o analfabetismo. Já a dimensão do desenvolvimento infantil relaciona componentes como o trabalho precoce, o acesso e o progresso escolar. E, finalmente, a dimensão das condições habitacionais considera a abrigabilidade, o acesso à água e saneamento básico, coleta de lixo e eletricidade.

Dados produzidos pelo IDF (JUIZ DE FORA, 2012) informam que 68,5\% das famílias de Juiz de Fora não têm a presença de cônjuges na organização das famílias, sendo que, desse percentual, 42,9\% têm crianças. Em relação ao trabalho, 62,2\% das famílias não têm membros ocupados no setor formal, e a média salarial de um salário mínimo é a renda de $81 \%$ dos lares. Já sobre o acesso à escola, Juiz de Fora possui 7.087 famílias que têm crianças de 0 a 6 anos fora da escola, o que corresponde a um percentual de 25,3\% das famílias pesquisadas. Sobre as condições de moradia, o IDF aponta que 98\% das famílias de Juiz de Fora (MG) vivem em agrupamentos de 2 pessoas por cômodo, 7,1\% das famílias não têm acesso adequado à água; $4,8 \%$ não têm acesso adequado à esgoto; $1,7 \%$ não tem seu lixo coletado e 2,5\% não têm acesso à eletricidade. Essa população está principalmente nas áreas periféricas atendidas pelas 11 unidades dos CRAS, e como a vulnerabilidade é critério para a seleção nas creches, mencionar tais dados é de suma importância, pois estes têm relação direta com a dignidade, o acesso e exercício dos direitos e serviços por parte da população, em especial as crianças e as mulheres.

Em relação às estruturações político-educacionais da Educação Infantil em Juiz de Fora, a Secretaria de Educação do município elaborou, em 2010 e em 2011, respectivamente, os dois documentos municipais norteadores da Educação Infantil. A proposta curricular Educação infantil: A construção da prática cotidiana (2010) e A prática cotidiana na EI: 
diálogos no cotidiano (2011) foram construídas por meio de intenso diálogo entre os profissionais da área, ocorridos em grupos de estudos, cujas produções articularam sobre uma afinação entre as concepções de crianças, suas infâncias, as dimensões e as práticas pedagógicas, postulando-se que não devem ser compreendidos de forma isolada, mas em constante interação (JUIZ DE FORA, 2010). Os dois materiais destacam que as crianças são sujeitos ativos, participativos, seres sócio-histórico-geográficos, e que devem "também devem ser vistas como possuidoras de processos de significação próprios e como seres brincantes e coletivos, que se singularizam na vivência com seus pares e com outros sujeitos" (RAMOS, 2016, p.86).

Obedecendo às prescrições do Plano Nacional de Educação (BRASIL, 2014), Juiz de Fora também construiu o seu Plano Municipal de Educação (PME), a partir das ações do Fórum Municipal de Educação, que contou com representantes de 25 instituições. As discussões geraram o documento oficial, homologado na forma da Lei $\mathrm{n}^{\mathrm{o}} 13.502$, de 28 de março de 2017, com vigência de 10 anos. O PME de Juiz de Fora estabelece em seu $2^{\circ}$ artigo as diretrizes gerais, que se propõem à...

I - Erradicação do analfabetismo;

II - Universalização do atendimento escolar;

III - superação das desigualdades educacionais, com ênfase na promoção da cidadania e na erradicação de todas as formas de discriminação;

IV - Melhoria da qualidade da educação;

V - Formação para o trabalho e para a cidadania, com ênfase nos valores morais e éticos em que se fundamenta a sociedade;

VI - Promoção do princípio da gestão democrática da educação pública;

VII- Promoção humanística, científica, cultural e tecnológica do País;

VIII - Estabelecimento de meta de aplicação de recursos públicos em educação como proporção do Produto Interno Bruto - PIB, que assegure atendimento às necessidades de expansão, com padrão de qualidade e equidade;

IX - Valorização dos(as) profissionais da educação;

$\mathrm{X}$-promoção dos princípios do respeito aos direitos humanos, à diversidade e à sustentabilidade socioambiental.

XI - Promoção de ações que visem a garantia da segurança física, mental e moral dos profissionais de educação no exercício da profissão.

Parágrafo único. Por diversidade entenda-se, no corpo desta Lei e dos seus anexos, estritamente, toda modalidade de Educação Inclusiva ou Especial, nos termos da Constituição Federal de 1988, da Convenção da Guatemala (1999) e da Lei ${ }^{\circ}$ 8.069, de 13 de julho de 1990 (JUIZ DE FORA, 2017, s/p, grifos nossos).

Nossa ênfase na terceira diretriz do PME se dá uma vez que ela acompanha o texto do atual Plano Nacional de Educação, que suprimiu o termo gênero do texto oficial após 
inúmeras disputas e discussões sobre a abordagem da categoria gênero na Educação. A supressão dessa categoria no PNE foi debatida em dissertação de Mestrado de Ramos (2016), cujas contribuições serão recuperadas brevemente aqui. Os termos do terceiro inciso do $2^{\circ}$ parágrafo do PNE, que versava sobre a "promoção da igualdade racial, regional, de gênero e de orientação sexual" foram substituídos na redação final do atual PNE. O mesmo artigo traz atualmente a prescrição voltada à "[...] superação das desigualdades educacionais, com ênfase na promoção da cidadania e na erradicação de todas as formas de discriminação" (BRASIL, 2014, p.22), prescrição esta reproduzida na íntegra pelo PME de Juiz de Fora (MG). Além de prescrição genérica, que não visibiliza, como na redação anterior, o cerne de questões ligadas aos preconceitos que deveriam ser combatidos desde a infância, o PME ainda ressalta que o termo "diversidade", evocado na décima diretriz se refere à inclusão no que toca à educação Especial. Em outras palavras, o PME municipal expressa o entendimento de "diversidade" em parágrafo único, como sendo privilegiada a dimensão de existência vivenciada pelas pessoas com deficiência, aparado inclusive em diretriz estabelecida pela Convenção da Guatemala, da qual o Brasil é signatário.

Cabe aqui uma ressalva sobre o termo "diversidade", na qual nos amparamos na dissertação de Mestrado da professora brasileira Fernanda Bichara da Silva, intitulada "Dos usos e abusos da diversidade como slogan". O termo "diversidade" tem sido atualmente empregado em uma infinidade de contextos dos quais se fazem necessárias designações do que é diverso, "as características ou elementos diversos entre si, que existem sobre um assunto, ambiente, etc.” (SILVA, 2016, p.23). Uma crítica do trabalho da citada autora vai na direção da polissemia da expressão "diversidade" para "conferir legitimidade a discursos que pretendem dispensar "igual tratamento" a travestis, pessoas com deficiência, negras e negros, lésbicas e gays, população de rua, transexuais e prostitutas", para citar alguns grupos de população. O questionamento da autora é justamente que o emprego genérico da expressão "diversidade" atua como um apagamento das especificidades das importantes lutas de enfrentamento à discriminação por parte de diversos movimentos sociais. Silva (2016) nos apresenta a necessidade da afirmação de qual expressão a "diversidade" se refere, para que se alcance a mudança “de corações e mentes", no sentido do qual o tema se propõe a debater as diferenças e desigualdades.

Logo, a partir das análises de Silva (2016), nos parece que o PME de Juiz de Fora (MG) - mesmo afirmando o legítimo reconhecimento social e educacional das pessoas com deficiência- se coloca na contramão das produções teóricas que debatem a desconstrução de 
preconceitos, visto que não menciona outras dimensões que afetam populações igualmente importantes, como as mulheres, pessoas negras ou indígenas, e que compõem a pluralidade brasileira, notadamente por acompanhar os discursos governamentais ${ }^{70}$. De acordo com Ramos (2016), ocorreram muitas interferências de setores conservadores, em especial aqueles setores cuja tendência se paute em dogmas religiosos. Outra materialização dessa interferência observada no PME é a tônica acerca da compreensão acerca da Cidadania e dos Direitos Humanos, que vale a citação em sua íntegra:

A promoção da cidadania e dos princípios do respeito aos direitos humanos e à diversidade não poderá se sobrepor aos direitos dos pais à formação moral de seus filhos, nem interferir nos princípios e valores adotados ao ambiente familiar, conforme assegurado pela Convenção Americana dos Direitos Humanos, Constituição Federal de 1988, Código Civil Brasileiro e demais normas infraconstitucionais (JUIZ DE FORA, 2017, art.2 ${ }^{\circ}$, s/p).

Esse artigo coloca os trabalhos pedagógicos da Educação Infantil de Juiz de Fora submetido aos princípios socializados no meio familiar, o que não está em consonância com o que a LDBEN prevê como finalidade da Educação Infantil, ou seja, contribuir para "o desenvolvimento integral da criança de até 5 (cinco) anos, em seus aspectos físico, psicológico, intelectual e social, complementando a ação da família e da comunidade" (BRASIL, 1996, art.29). Logo, outras práticas, que não outras senão as já acessadas no seio da família, poderão ser questionadas, o que não seria um problema, se fosse reafirmado no documento o direcionamento do papel complementar da Educação na socialização de outros valores.

Ao lado disso, vale notar que o Brasil também é signatário da Convenção sobre a Eliminação de Todas as Formas de Discriminação contra a Mulher (CEDAW), cujos EstadosPartes se comprometem em "abster-se de incorrer em todo ato ou prática de discriminação contra a mulher e zelar para que as autoridades e instituições públicas atuem em conformidade com essa obrigação" (CEDAW, art.2º alínea d, 1979, p.2). Deste modo, ao não mencionar o combate à discriminação da mulher, não obstante reforçar e amparar a discussão da diversidade em apenas uma dimensão, o documento deixa de cumprir acordo internacional, bem como deixa de incentivar relevantes debates sobre questões sociais importantes que

\footnotetext{
${ }^{70}$ Após a escrita desse capítulo, houve outro desdobramento relativo à discussão sobre a restrição do termo diversidade contida no PME de Juiz de Fora. Em decisão judicial, tal restrição foi considerada inconstitucional. Essa informação pode se acessada em https://tribunademinas.com.br/noticias/politica/02-09-2020/tjmg-considera-inconstitucional-restricaoa-diversidade-em-plano-municipal-de-educacao-de-jf.html Acesso em 02/07/2021.
} 
afetam o usufruto aos Direitos Humanos e a cidadania plena de mulheres e de crianças, e de todas as pessoas, por terem sua educação afetada por esse descaso.

Feita essa complementação, retornemos ao âmbito da Educação Infantil. O PME de Juiz de Fora destina uma meta, a de número 1, à educação das crianças pequenas. A citada meta prevê.

Universalizar, até 2016, a Educação Infantil para as crianças de 04 (quatro) e 05 (cinco) anos de idade e ampliar a oferta de Educação Infantil em creches de forma a atender às crianças de até 03 (três) anos, até o $5^{\circ}$ (quinto) ano de vigência do Plano Municipal de Educação, alinhando o percentual de atendimento ao que foi estabelecido no Plano Nacional de Educação, condicionado ao apoio técnico e financeiro da União (JUIZ DE FORA, 2017 ,

$\mathrm{s} / \mathrm{p})$.

Para a concretização dessa meta, o PME detalha uma série de estratégias a serem adotadas pela Secretaria de Educação, em parceria com as unidades educacionais para a universalização do acesso e a ampliação do atendimento, tais como a supressão de convênios, articulação de ações junto à núcleos de pesquisas e cursos de formação, o monitoramento da demanda, o atendimento integral à crianças com deficiência, transtornos globais e altas habilidades, a implementação de Programa de Proteção à Infância, acompanhamento do acesso e permanência, ampliação do tempo integral, bem como promover a otimização dos trabalhos da Educação Básica promovidos pela iniciativa privada e zelar pela especificidade da Educação Infantil em consonância com os parâmetros nacionais e com as Diretrizes Nacionais Educacionais para a Educação Infantil.

De modo geral, observa-se que o município de Juiz de Fora tem procurado avançar na direção de promover uma Educação Infantil de qualidade, como na iniciativa precoce de promover a municipalização da Educação Infantil, anterior à prescrição da LDBEN, e na promoção de diálogos significativos e democráticos sobre a área, em movimento de afinação com a construção da política educacional brasileira, ainda que em muitas passagens relatadas, não tenha adotado as melhores estratégias para o atendimento às crianças pequenas. Tal quadro configura um caminho social, histórico e político comum, de avanços, estagnações e reformulações que acompanham a tendência nacional, como o olhar assistencial, a precariedade dos serviços e o rompimento tardio com a área da assistência, ao lado de problemas estruturais significativos, como a escassez de recursos e investimentos. Também chamamos a atenção para a urgente necessidade de aprofundamento das discussões que tratam da diversidade, pois o olhar impresso à Educação pela municipalidade falseia o pressuposto 
em que se baseia a Pedagogia Engajada, preconizada pela professora feminista estadunidense bel hooks (2013).

A autora (2013, p.20), ao idealizar práticas pedagógicas radicais, voltadas para a transformação social, afirma que é essencial "incluir um verdadeiro reconhecimento social das diferenças-determinadas pela classe social, pela raça, pela prática sexual, pela nacionalidade, e por aí afora", no que pode ser rica a contribuição dos Feminismos, em debaterem suas pautas, em suas vozes, na área da Educação, nos múltiplos modos de socialização dessas discussões.

Delineado o panorama educacional local, e pontuadas as principais questões e olhares envolvidos na educação das crianças pequenas, passamos a conhecer o olhar das professoras de uma creche do município sobre as questões que envolvem os direitos das crianças e dos direitos das mulheres. 


\section{RETRATOS DO CAMPO: A DIMENSÃO DOS DIREITOS DAS CRIANÇAS E DAS MULHERES A PARTIR DA CRECHE}

O presente capítulo traz as dinâmicas desenvolvidas a partir das análises da etapa da pesquisa de campo, realizada no período dos meses de março a dezembro do ano de 2019. A pesquisa consistiu em 6 (seis) encontros formativos com professoras de uma creche em Juiz de Fora em que foram debatidos materiais selecionados para promover discussões sobre os direitos das crianças e os direitos das mulheres. Os comentários das professoras foram gravados em áudio, que posteriormente foram transcritos e categorizados a partir dos elementos apontados e/ou silenciados nas falas. Foi requisitado às professoras, no início e no fim da pesquisa de campo, que redigissem comentários escritos que expressassem seus entendimentos acerca da interface entre os direitos das crianças e os direitos das mulheres, tendo como locus a creche.

Os enfoques e impressões das professoras foram analisados à luz da bibliografia adotada na tese, distribuídas em duas grandes categorias, cuja construção se pautou no entendimento feminista de Cidadania. Nas palavras de Marques Pereira (2009, p.), a cidadania corresponde à "prática de conflito ligada ao poder e às lutas para o reconhecimento dos atores considerados protagonistas de reivindicações legítimas. Ela é também ligada a uma prática consensual de participação e representação, bem como de formação das políticas públicas" (MARQUES PEREIRA, 2009, p.39). Considerando tal pressuposto, as duas grandes categorias foram denominadas como Práticas constituintes de Cidadania e Práticas não constituintes de Cidadania.

Essas duas categorias principais foram elaboradas a partir dos enfoques sobre os direitos das crianças e dos direitos das mulheres, em comparação aos silenciamentos sobre os mesmos, amplamente debatidos na tese. Tal comparação se baseou no que a tese entende pela maternagem, em uma perspectiva feminista, alinhada com a corresponsabilização prevista na legislação brasileira. A maternagem defendida na tese é a incumbência e responsabilidade da educação das crianças, pela família, por equipamentos de proteção e educação, e pela sociedade como um todo, noção essa obtida a partir de releitura das análises de Meyer (2006) e do artigo sobre a Educação da Constituição brasileira.

A categoria Práticas constituintes de Cidadania comporta as reflexões que privilegiam o enfoque dos direitos, bem como a socialização de práticas acolhedoras, transformadoras e respeitosas, no que supomos serem critérios que contribuam a uma ampliação dos horizontes e fins da Educação, pensados em uma perspectiva feminista. Do 
acesso aos dados de campo, essa grande categoria se dividiu em subcategorias, a partir dos olhares socializados nos encontros formativos, abrangendo e perpassando as seguintes temáticas: Percepção de direitos e Socializações igualitárias.

A subcategoria Percepção de direitos compreendeu reflexões que, quando de apontamentos sobre as crianças, trouxeram enfoques relacionados ao respeito, afeto e proteção. No que compete às mulheres, nessa subcategoria se encaixaram reflexões que apontaram para o reconhecimento de demandas, necessidades e sobrecargas ligadas ao âmbito do trabalho de modo geral.

Já a subcategoria denominada Socializações igualitárias surge de menções que denotaram a materialização da ruptura com as construções de gênero conservadoras, como a existência das brincadeiras de modo compartilhado e/ou coletivo. Como agentes dessas ações, as crianças. Outra materialização de ruptura, que foi incluída nessa subcategoria, tem como agentes as educadoras, que demonstraram acolhimento e incentivo nas mesmas brincadeiras, e, em assim o sendo, entendemos haver alguma ampliação de referências não sexistas.

A segunda principal categoria, denominada Práticas não constituintes de Cidadania surge a partir de discussões que indicaram alguma superficialidade, invisibilidade, equívoco ou prejuízo sobre a percepção dos direitos das mulheres e/ou os direitos das crianças. Essa categoria nasce a partir dos dados que indicaram indícios de resistências conservadoras, no que compete aos olhares sobre o gênero, classe, raça ou geração, o que, em nosso entendimento, comprometem a percepção sobre os direitos, e com isso, se reduz a magnitude da maternagem na creche. Para sinalizar em quais discussões esses dados se fazem presentes, surgem as subcategorias Resistências conservadoras e Práticas conservadoras.

A subcategoria Resistências conservadoras comporta menções ligadas aos entendimentos que demonstram a materialização de modelos de comportamento hierarquizadores e tradicionais. Nessa subcategoria estão os dados que sinalizaram a reprodução de modelos conservadores por parte das famílias, das crianças e das professoras. Conforme apurado em campo, essa materialização ocorre, na interação família-creche, em intervenções do homem pai. Já por parte das professoras, a resistência se apresenta nas dificuldades em distinguir a mulher por trás da mãe, na romantização da maternidade, em julgamentos de valor endereçados às mulheres e na banalização das questões reprodutivas. No comportamento das crianças, as participantes observaram atos de censura proferidos por elas, por associação por cores e objetos. 
Das concepções observadas, buscou-se apurar como, ou a partir de que, esses modelos se materializam. Surge, então, a subcategoria Práticas conservadoras de gênero, que nos revela que, concretamente, no cotidiano do campo, as professoras contribuem para um quadro apagamento da figura da mulher, enquanto se delineia uma noção de divisões de objetos pautadas por sexo às crianças. Sobre a interação família-creche, surge a figura do homem, que intervém como autoridade em situações que sejam "ameaçadoras" às masculinidades convencionais.

No decorrer dos encontros formativos, foram registradas observações que fizeram emergir uma terceira categoria de dados. A categoria Imbricações de Cidadania surge a partir da produção de reflexões que, ao considerar os sujeitos beneficiados pela tese - crianças e mulheres- sinalizaram possibilidades de visibilizar outros olhares possíveis a essas pessoas e, também, às realidades e direitos que ambas compartilham.

Ao lado disso, questões correlatas ao tema da tese, abordadas pelas participantes na fruição dos debates, foram analisadas em separado, a fim de privilegiar outras dimensões igualmente importantes ao campo. Essas compõem o capítulo 5 da tese, configurando um pano de fundo desafiador ante a construção da socialização da maternagem.

Como subtítulos das seções desse, e do próximo capítulo, foram adotadas as próprias falas das participantes da pesquisa de campo, selecionadas e visibilizadas com a finalidade de enunciar as principais temáticas abordadas em cada um dos encontros formativos. Contamos com a presença das 16 mulheres que concordaram em participar dessas dinâmicas, em todos os seis encontros formativos realizados.

\subsection{ENCONTRO PRELIMINAR: APRESENTANDO A CRECHE E AS PARTICIPANTES DOS ENCONTROS FORMATIVOS}

A creche-campo tem sua estrutura física dividida em dois pavimentos: o andar térreo conta com um hall de entrada, em que se localiza um pequeno bazar e um quadro de avisos. É nesse andar que se localiza a secretaria e a sala da coordenação da creche. $O$ primeiro pavimento também conta com uma sala de aula e três banheiros (um destinado a pessoas adultas), depósito de materiais pedagógicos e uma brinquedoteca. O corredor de acesso conduz a um amplo refeitório, à cozinha e a um parquinho ao fundo. $\mathrm{O}$ acesso ao segundo pavimento se dá por uma rampa, local que são expostas as atividades das crianças. Esse andar superior possui 6 salas de aula, dois banheiros destinados às crianças e o berçário. Anexo ao 
berçário, existe outro parquinho. A creche-campo situa-se em bairro de periferia de Juiz de Fora (MG), e atende crianças de 12 meses a 3 anos e 11 meses.

Figura 4. 1: Sala de aula e ilustração do corredor da creche
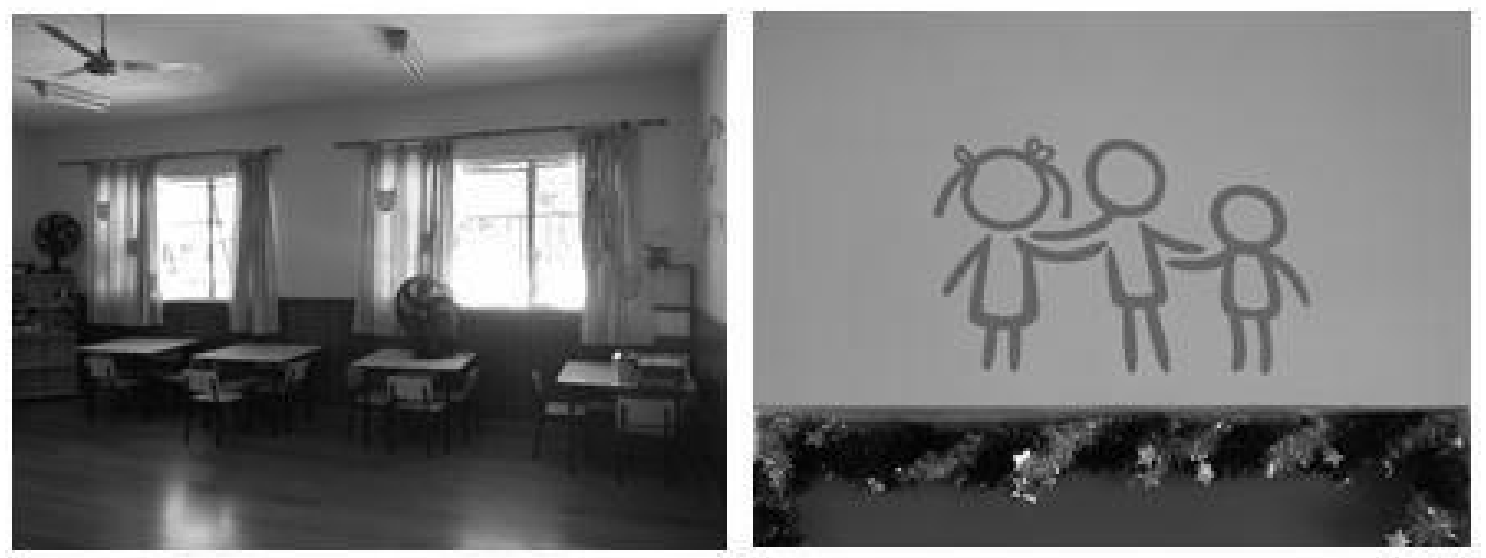

Fonte: Acervo de pesquisa da autora

Figura 4. 2: Parquinho e banheiro das crianças
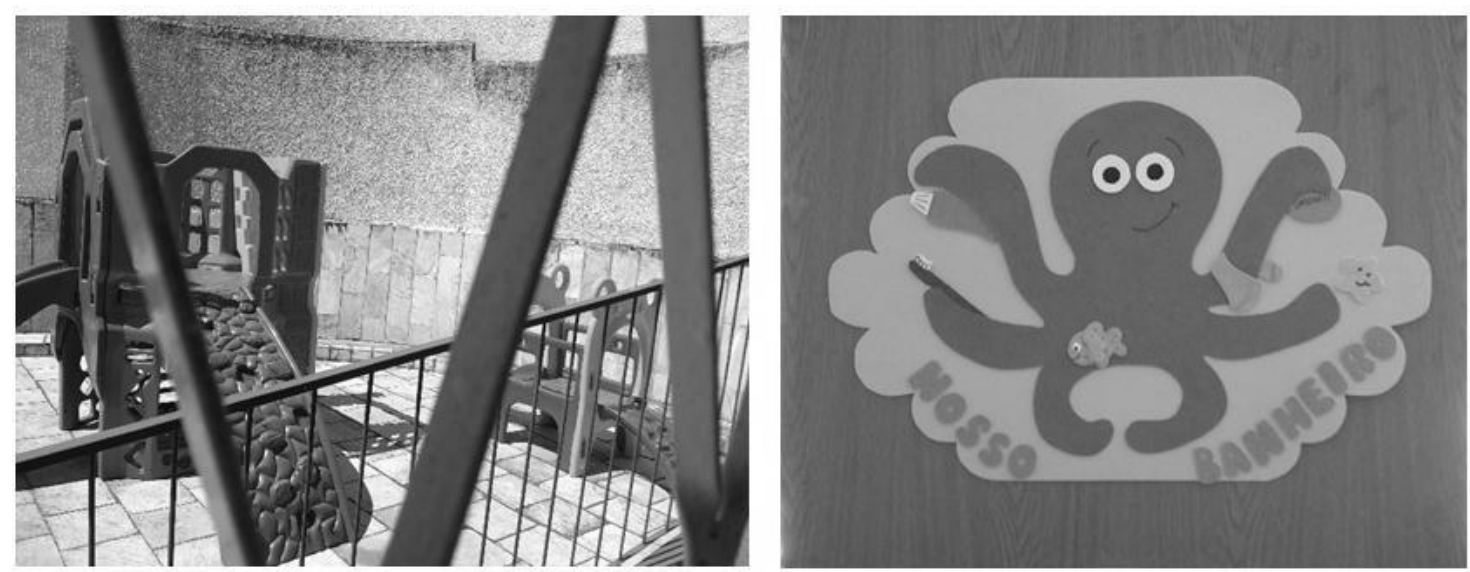

Fonte: Acervo de pesquisa da autora

Todas as profissionais da creche concordaram em participar, totalizando um grupo de 16 pessoas, 16 mulheres. O grupo agregou 14 professoras, a coordenadora da creche e a profissional de serviços gerais. Num encontro preliminar, foi apresentado todo o teor da pesquisa, bem como sanadas todas as dúvidas sobre as dinâmicas de realização da pesquisa, tendo em vista que a creche nunca havia participado de pesquisa acadêmica. Estando todas em 
concordância, iniciamos com um contato interpessoal, com a apresentação das professoras e da pesquisadora, que informaram nome, tempo de trabalho na creche e formação.

Das 16 participantes, 5 possuem ensino superior concluído, das quais 3 são formadas em Pedagogia e 2 em Normal Superior. Uma professora informou que estava cursando uma pós-graduação em Educação. Das 11 pessoas restantes, 7 estão cursando Pedagogia e 1 pessoa faz graduação em Educação Física. Ao lado disso, duas professoras possuem somente o Curso de Magistério e 1 não informou a escolaridade. Das professoras que possuem a graduação completa ou ainda em curso, 6 também fizeram o curso em nível de Magistério. O tempo que as professoras trabalham na creche-campo varia de 1 mês a 6 anos.

\section{2 “UM LAÇO DE GRANDES DESCOBERTAS, APRENDIZAGEM E AMOR”: MÃES, CRIANÇAS E CRECHES}

Nesse primeiro encontro formativo, foi proposto às participantes que redigissem um comentário escrito sobre da proposta geral da pesquisa, a fim de familiarizar a pesquisadora sobre o entendimento delas acerca do grande tema direitos das crianças e direitos das mulheres via creche. A pergunta geral foi "como vocês compreendem a maternidade e o acesso à creche?".

Sobre a maternidade, muitos comentários enalteceram a importância desse momento na vida da mulher, assim como as diversas emoções e atribuições que ganham uma maior proporção quando ela se torna mãe. A partir dos trechos abaixo, podemos acessar os sentimentos relacionados à experiência vivida, especialmente, as construções sociais de doação, cuidados e abnegação que se espera de uma mãe, elementos esses já explanados na tese no capítulo 1, pelos escritos de Elisabeth Badinter (2009) e Erica Burman (2009), que versaram sobre como comumente a maternidade é lida e internalizada socialmente. 
Figura 4. 3: Participante Juliana

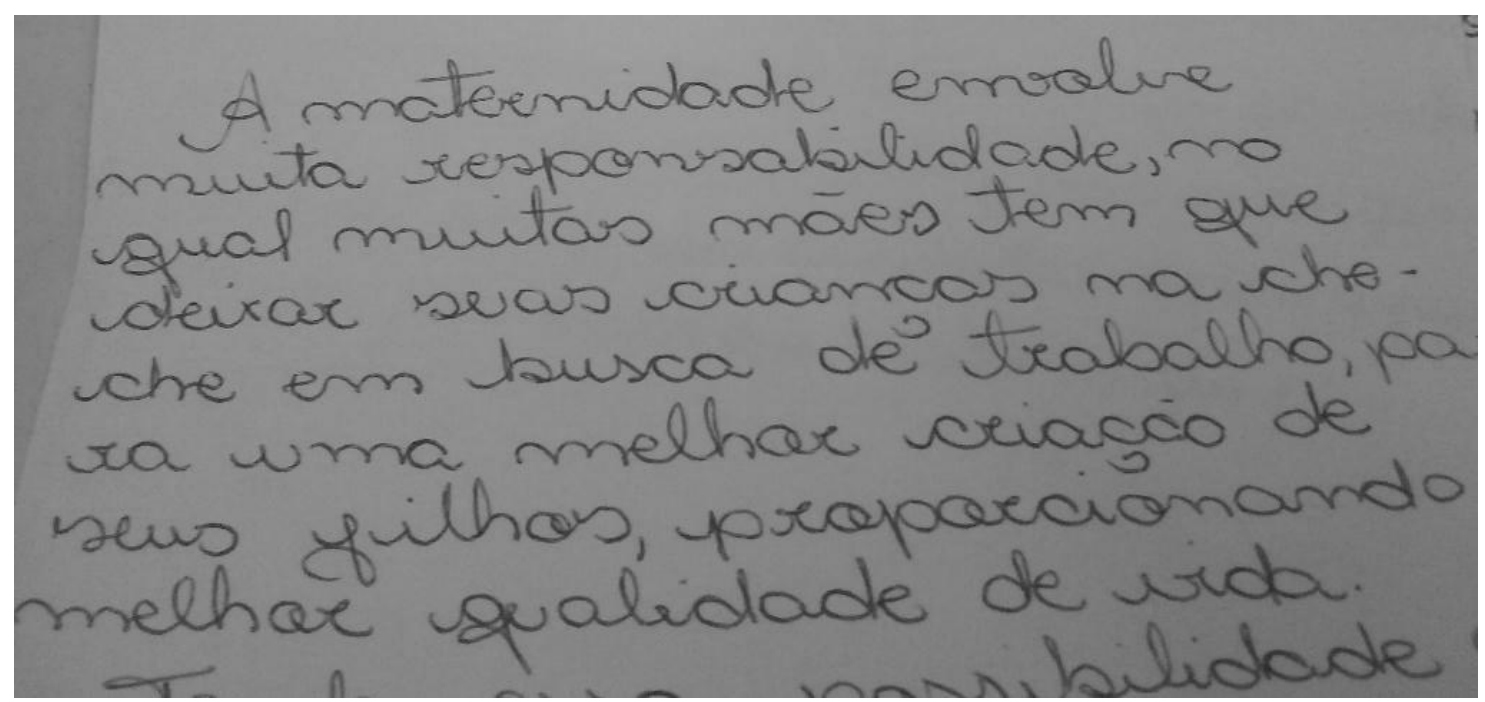

Figura 4. 4: Participante Elô

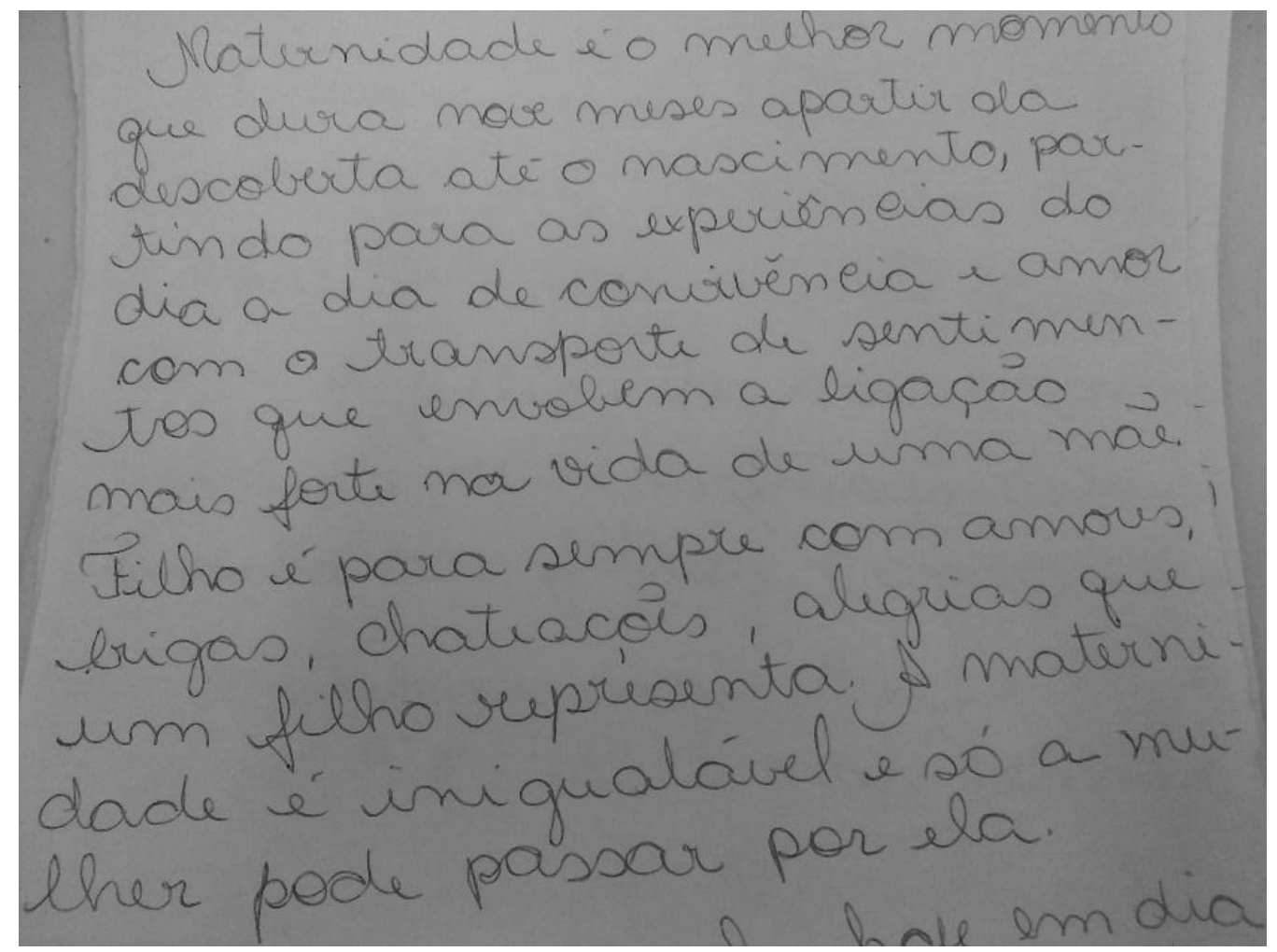

Fonte: Acervo de pesquisa da autora.

As impressões das entrevistadas acerca da maternidade são interessantes pelo modo como opinam sobre o que nos parece ser "o ônus e o bônus de uma mãe". Enquanto Juliana ${ }^{71}$ (Figura 4.3) aponta o encargo da responsabilidade, relacionando-a com o trabalho da mulher,

\footnotetext{
${ }^{71}$ Foram utilizados nomes fictícios a fim de resguardar a privacidade das participantes.
} 
situa a creche como um veículo para se buscar a qualidade de vida, Elô (Figura 4.4) disserta sobre os sentimentos que a maternidade desperta, exaltando-a como experiência afetiva ímpar, sem deixar de mencionar, de outra maneira, a responsabilidade sobre isso, dizendo que "Filho é para sempre”. As idealizações que envolvem a figura materna, bem como as questões relativas ao trabalho e atividades profissionais foram debatidas por Badinter (1985) e são o retrato das elaborações das entrevistadas. Conforme a autora, as construções sobre a mãe, difusas no imaginário social são acessíveis, e sempre as mesmas: o amor imaculado e incondicional, a realização pessoal e a ideia da obrigação. Badinter (1985, p.9) afirma que tais construções são de tal força que "Continua difícil questionar o amor materno, e a mãe permanece, em nosso inconsciente coletivo, identificada a Maria, símbolo do indefectível amor oblativo". Tanto que a associação com a dimensão divina foi mencionada também por Sueli.

Figura 4. 5: Comentário Sueli

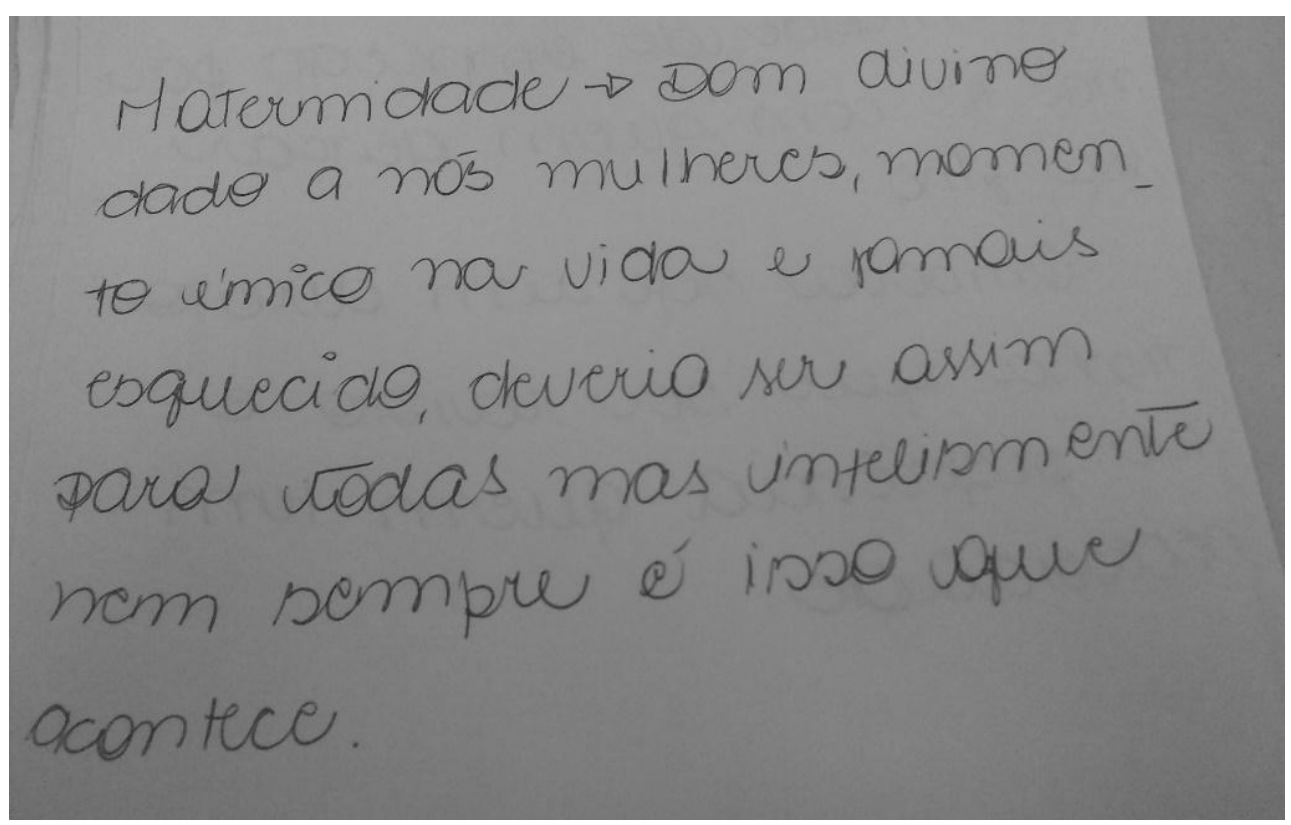

Fonte: Acervo de pesquisa da autora.

A partir do comentário de Sueli (Figura 4.5), observa-se a associação das paixões sociais coletivas relacionadas ao ofício "sagrado" de ser mãe, que, de tão pronunciado ainda nas sociedades, aponta ao final um lamento, por nem todas as mães conceberem a dimensão da fundamentalidade afetiva e social que a maternidade carrega em si. Isso também sinaliza outra possibilidade de análise: as citadas participantes não colocam a maternidade como uma opção. Tal dado remete ao foco do trabalho da historiadora brasileira Tania Maria Gomes da Silva (2013), que ao publicar artigo intitulado Mulheres, maternidade e identidade de gênero, analisa que, mesmo com outros olhares acerca da maternidade, como a notória diminuição do 
número de filhos/as por mulher no Brasil, as/os filhas/os ainda são fortes elementos constituintes das identidades das mulheres. A presente tese não tem a intenção de reforçar o essencialismo, apenas pontuar, assim como Silva (2013) que as identidades se constroem a partir do cotidiano vivido.

Desse modo, tanto são cabíveis as narrativas de maternidades como um sonho, quanto aquelas em que as mulheres não priorizem, ou não desejem a maternidade. Considerando tal premissa, não se nota, nas falas das participantes, alguma consideração de outras possibilidades de conceber a maternidade, a não ser como algo próximo de uma dádiva. Logo, por seu caráter restrito, tais comentários levam ao entendimento de uma Prática não constituinte de Cidadania, pois carregam a ideia do apagamento da mulher enquanto sujeito, pressupondo a maternidade como um destino do qual não se pode escapar.

Badinter (1985) pondera que o foco na maternidade afeta outras sociabilidades. No caso das mulheres, ao enaltecer a mãe, tendo como argumento de autoridade o sentimento do amor, a esfera do trabalho também se remodela. A autora analisa que a partir do XVIII, as mudanças relacionadas à modernização das sociedades e ao desenvolvimento destas, colocam como central o advento do trabalho. Nesse sentido, assevera que o valor social da mulher-mãe alterou-se, a partir de olhares sobre o papel delas na sobrevivência das crianças, em prol do desenvolvimento da nação. Decididamente, os elevadíssimos índices de mortalidade infantil dos séculos anteriores não condiziam com o desenvolvimento, tampouco colaboravam na potencial oferta de mão de obra, necessária à geração de riquezas ao Estado. Logo, as obrigações e cuidados familiares, bem como a visibilização da pequena infância, foram se modificando, caindo em desuso costumes comuns à época, como a utilização de amas de leite e a criação das crianças fora dos domicílios familiares (BADINTER, 1985).

Também à luz do que a autora explana, sobre a construção dos "lugares" de mulheres e crianças, é interessante pensar sobre a construção do não-lugar, já mencionado no capítulo 2, por Araújo (2014) e Lopes (2008). No que diz respeito às mulheres, e a posição delas com relação à maternidade, ainda é orientada por uma lógica machista, pois as subjuga em termos de autonomia, como é o que ocorre nas discussões relacionadas ao aborto e o olhar socialmente preconceituoso para com as mães solo, que têm suas crianças advindas do ato sexual, ou não, como aquelas que recorrem à reprodução assistida ou pela adoção. Outra manifestação de desrespeito à autonomia das mulheres vem do acesso à laqueadura, que dispõe de critérios etários mínimos, e se a mulher for casada, é necessária a concordância do marido para realizar o procedimento. Diante dessas questões, perguntamos: como nos 
tornamos mulheres, enquanto existirem socializações essencializadoras e que naturalizam pressupostos biológicos de modo a igualar todas as mulheres, todas as maternagens, todas as maneiras de ser mulher?

A questão da sobrevivência, do crescimento da vida urbana e do progresso colocam a necessidade de buscar alternativas aos cuidados com as crianças, diante das mulheres que passam a trabalhar, também, fora de seus lares, a fim de buscar o sustento de suas famílias (NUNES; CORSINO; DIDONET, 2011). Essa necessidade primeira é a grande marca do nascimento das creches em todo o mundo, rememorada no comentário de Juliana, mesmo com o reconhecimento da Educação como direito das crianças já ser vigente no Brasil desde a promulgação da Constituição em 1988. Sueli (Figura 4.6) menciona esse direito, mas o condiciona ainda à dimensão das necessidades de trabalho da família.

Figura 4. 6: Comentário Sueli.
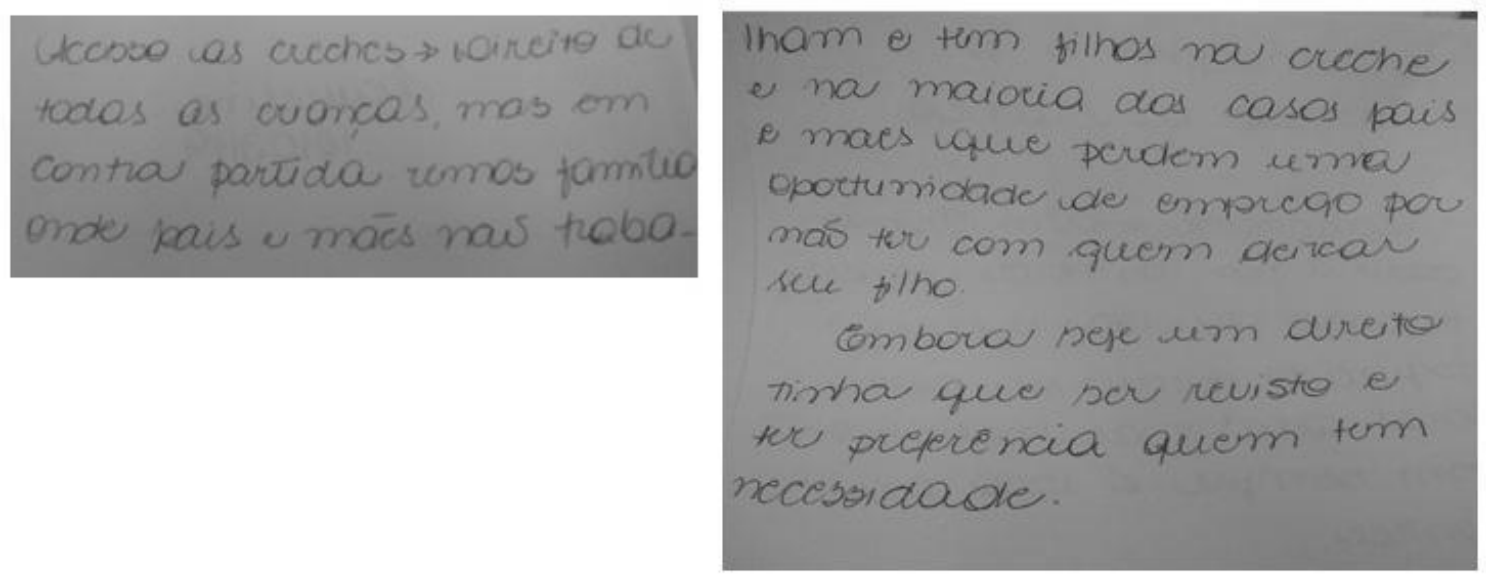

Fonte: Acervo de pesquisa da autora.

Outro ponto evocado na percepção de Sueli sobre a maternidade e a creche - o de a creche ser a alternativa para quem não tem com quem compartilhar os cuidados com as crianças - também remete às análises de Fonseca (2000) e Campos (2012), constantes no capítulo 2 da tese. A primeira autora, ao nos trazer colocações sobre as buscas das mulheres em construírem redes de cuidado para com as crianças, descortina o panorama de abandono e contexto econômico precário de grande parte das famílias brasileiras. Que, ao ser debatido, também pela segunda autora, torna possível vislumbrar a tendência de omissão por parte do Estado, que historicamente vincula suas prioridades à esfera econômica. Isso gera impactos nas políticas de educação, pois ao se desconsiderar a questão de fundo - condições estruturais produtoras da pobreza - a creche segue admitida comumente, rememorando Rosemberg 
(1984), como uma tábua de salvação contra a pobreza, tendo sua função cidadã desprestigiada, a uma ação secundária, como exposto no capítulo 3 da tese. Ainda assim, o entendimento atual sobre a assistência corresponde a um direito. Temos aqui uma tensão sobre as faces que a assistência pode adquirir, pela dimensão do acesso e pela dimensão do usufruto. De todo modo, o comentário de Sueli remete ao acesso, ou seja, à existência concreta de creches, possibilidade importante de construção de Práticas constituintes de Cidadania, pois representa o direito das crianças à Educação, e recurso que significa mudanças também na vida da mulher-mãe.

Ainda que perdure socialmente esse entendimento sobre a creche, notamos em outros depoimentos a presença de opiniões como a de Carmen (Figura 4.7), que aponta para o reconhecimento da função educadora e da socialização das crianças, bem como o compartilhamento da tarefa de educar junto às famílias, pontuado por Christina (Figura 4.8), o que denota que a concepção tradicional sobre essa instituição vem sendo ampliada, o que indica uma Prática Constituinte de cidadania pelo olhar sensível da Educação Infantil à criança como sujeito em desenvolvimento, o que compreende uma valorização enquanto cidadã em formação, em uma prática socializada.

Figura 4. 7: Comentário Carmem

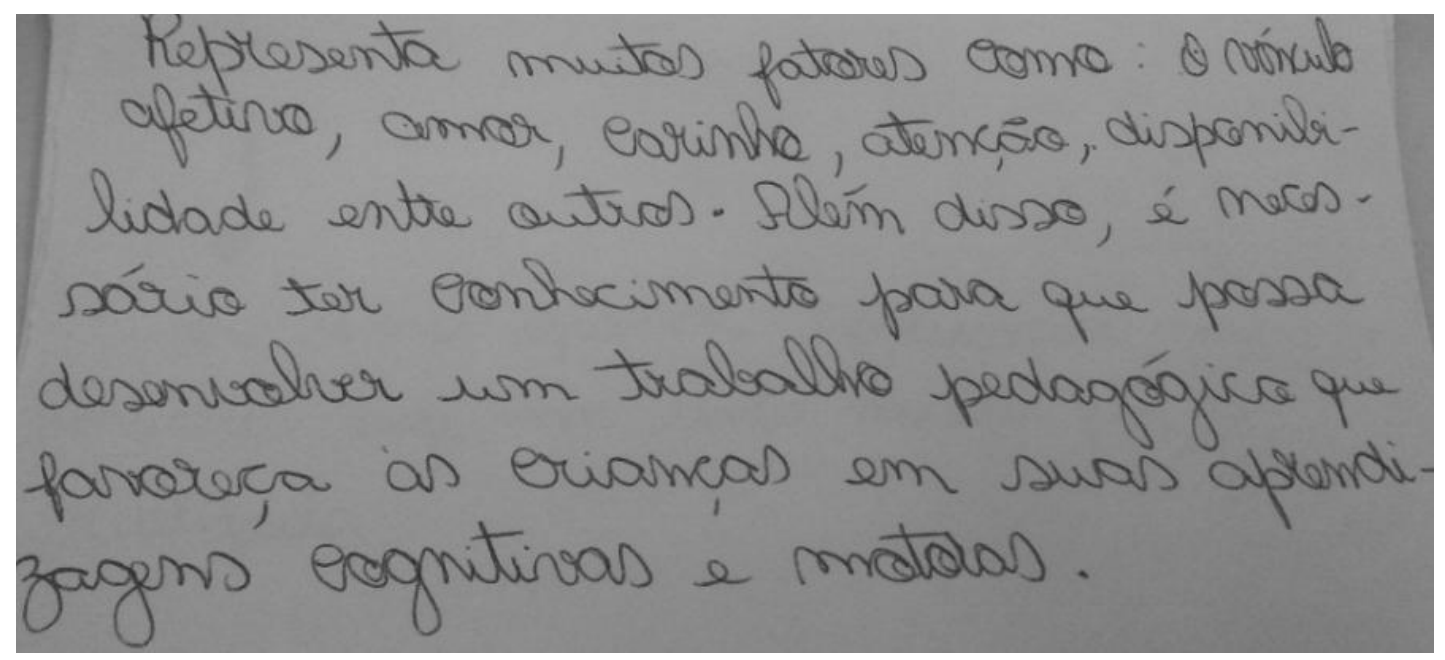

Fonte: Acervo de pesquisa da autora. 
Figura 4. 8: Comentário Christina

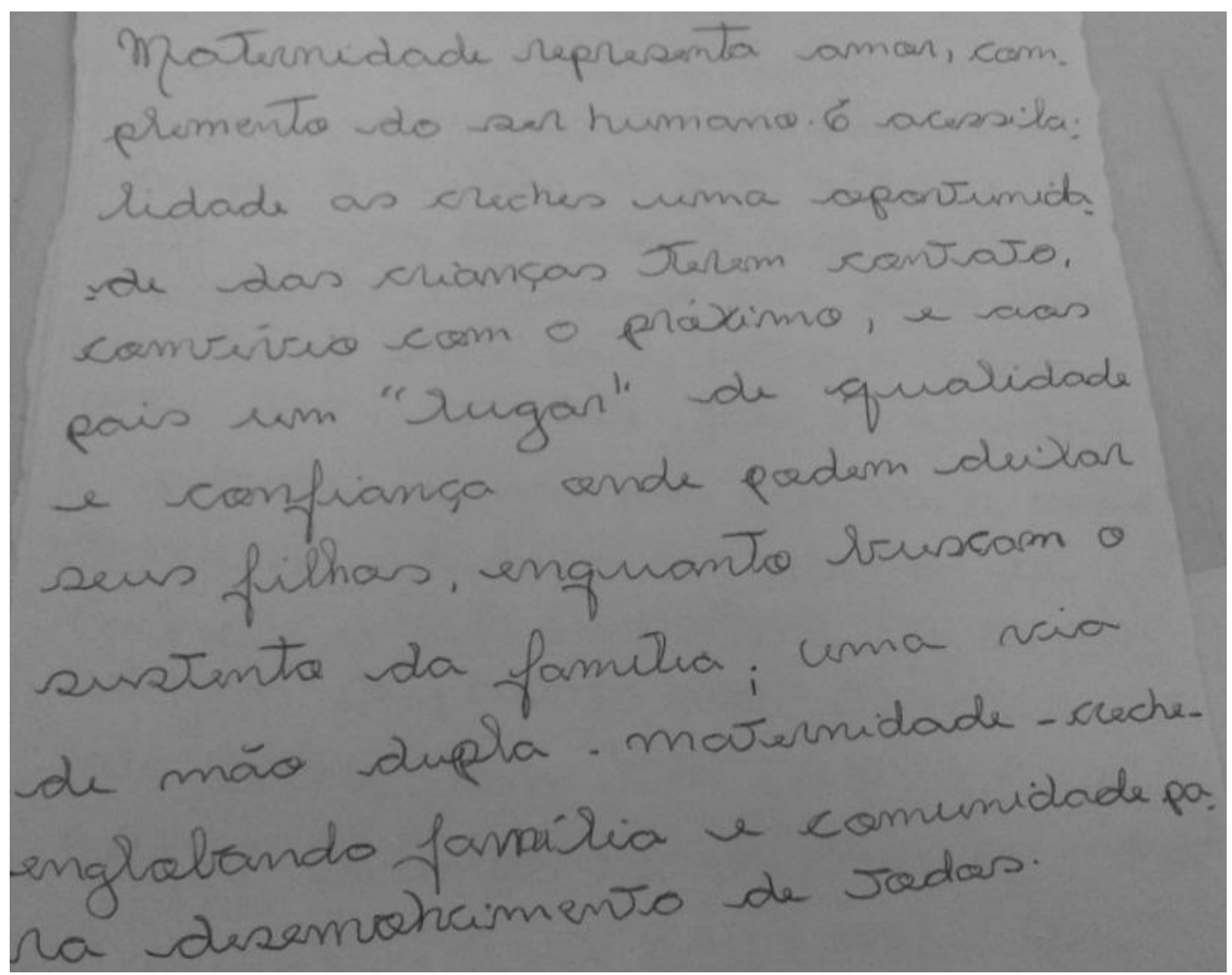

Fonte: Acervo de pesquisa da autora.

O comentário de Christina (Figura 4.8) sintetiza os elementos mais presentes nas construções sociais sobre a maternidade e a creche, como o amor, a socialização da criança para além da família e a dimensão da necessidade do trabalho. No entanto, a entrevistada coloca o par maternidade-creche como em que família e comunidade se encontram, "para o desenvolvimento de todos". Essa consideração se aproxima com os estudos de Resende e Machado (2012), que defendem que a Educação tem de se comprometer, também, com as relações inerentes aos processos educativos, como a relação com as famílias, acrescentando-se a isso o direito de proteção integral das crianças por parte da família, sociedade e Estado, prescrito no Estatuto da Criança e do Adolescente, como debatido no capitulo 1. Ainda que a mãe figure como responsável direta pela educação das crianças, como exposto no comentário da entrevistada, nota-se uma ampliação no entendimento de participação de outros entes nessa tarefa, o que indica uma Prática constituinte de Cidadania, indicativo de um possível processo de reconstrução da maternagem, da forma que é defendida na tese. 
Duas participantes fizeram colocações sobre a influência da maternidade em suas carreiras como educadoras na creche, como apontado por Elisângela (Figura 4.9). As práticas dos cuidados, que estabelecem suas bases na relação mulher-criança, foram discutidas no capítulo 1 da tese, amparadas nos estudos de Pena (2015) e de Auad (2004).

Figura 4. 9: Comentário Elisângela

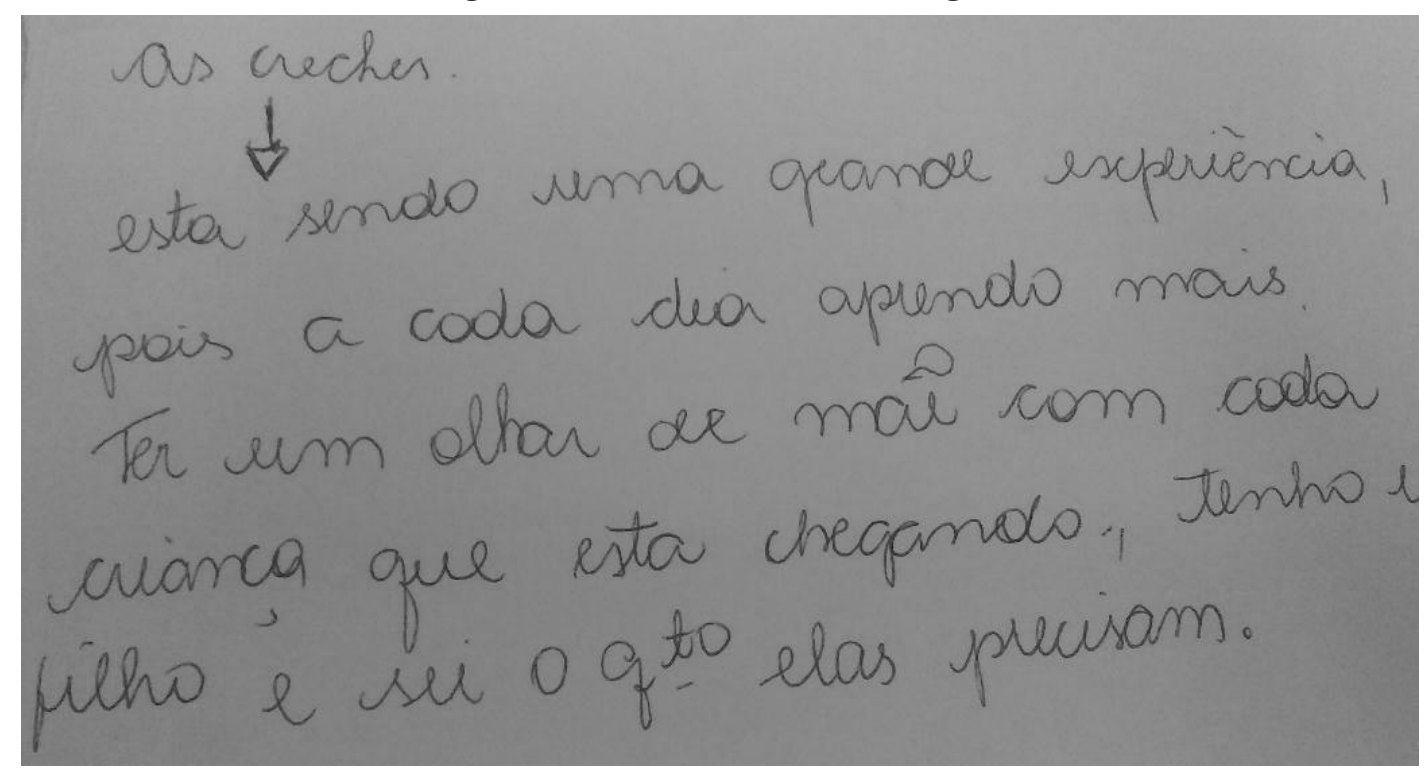

Fonte: Acervo de pesquisa da autora.

Os debates acessados pelas autoras analisam que a transposição social errônea de adjetivos ocorre em múltiplas dinâmicas no âmbito das profíssões, como aqueles que se associam ao gênero. A associação de uma perspectiva materna à carreira de professora é problemática, pois além de não comportar a sistematização técnica que a profissão docente exige, se reverbera em condições precárias de trabalho, uma vez que as profissões ligadas ao cuidado são mal remuneradas e desprestigiadas socialmente (HIRATA, 2016). A Educação Infantil, que conta com um perfil massivo de trabalhadoras mulheres, ainda conta com as expectativas de associação com a maternidade como uma regularidade social forte, como exposto nos capítulos 1 e 3 da tese. Isso corresponde a uma Prática não constituinte de Cidadania, pela atuação das relações de gênero tradicionais na esfera profissional, justamente pela desvalorização que o amparo em socialização primária, advinda do âmbito familiar, e baseada em habilidades de cuidado, acarreta ao ofício de professora, que requer formação técnica e acadêmica, como outras tantas profissões.

Logo após o movimento de escrita, as participantes socializaram suas opiniões, em um movimento de ampliação sobre cada colocação em pauta, em dinâmicas que refletiram sobre uma triangulação de questões, como a questão da creche como recurso para a sobrevivência 
familiar e a necessidade de cuidados e carinho para com as crianças. Também foram visibilizados os conflitos com a visão de trabalho profissionalizado nas creches, confrontados aos cuidados maternais.

As participantes relataram nesse debate que "Quem é mãe e conhece a creche é uma, e a partir do momento que a gente é mãe e tá aqui dentro, a visão é outra" (Participante Sueli). Essa mudança de olhar nos sugere um movimento que se aproxima com a reflexão sobre as construções acerca da tríade mãe-mulher-professora ${ }^{72}$, concepção debatida em artigo de Daniela Auad e Maria Rita Ramos, intitulado Relações de Gênero e Docência na Educação Infantil: interfaces entre políticas públicas e abordagens pedagógicas (2015). A citada tríade diz respeito ao errôneo olhar histórico de associação da figura da mãe à da professora, pela correspondência direta de elementos como o afeto e a proximidade com crianças a uma dotação "natural" à carreira docente, pelo simples fato de a pessoa ser uma mulher.

Sobre isso, as autoras dizem que é preciso superar as históricas correspondências de que basta ser mãe para ser professora. O que se pode aferir, pelas análises de Auad e Ramos (2015) e o comentário de Sueli é que, ainda que marcado pelas expectativas de gênero, a vivência concreta do oficio de professora pode gerar reflexões acerca dessas expectativas, já que rompe com a superficialidade de construções sociais comumente difundidas, como a de que a mãe seja a única e mais adequada referência de educação e cuidados, e de que o trabalho na creche seja semelhante aos cuidados em âmbito doméstico. Isso nos permite pensar que a construção da tríade mãe-mulher-professora, que perpassa o olhar sobre a carreira docente na Educação infantil é passível de ser reelaborada, tanto pela vivência concreta quanto pelo conhecimento teórico.

A participante Sueli pontuou que, embora ela tivesse acesso à creche quando do nascimento de seus filhos, mencionou que muitas mulheres escolhem não ter filhos por não disporem de ajuda, “- Aí, acaba que é uma mão na roda”. Logo, para além da creche ser equipamento consolidador do direito à Educação, potente construtor de aprendizagem, "- Para gente poder ajudar as crianças também" (Participante Helena), a creche também representa independência e autonomia das mulheres (TELES, 2015), tanto em suas escolhas de

\footnotetext{
${ }^{72}$ A tríade mãe-mulher-professora é um conceito pensado pela Profa. Daniela Auad desde os tempos de sua graduação, na Faculdade de Educação da Universidade de São Paulo, tendo sido registrado em relatório de pesquisa para aquela instituição, na década de 90 . O conceito foi revisitado pela professora em variados momentos de suas reflexões e recuperado no artigo de Auad e Ramos (2015). A tríade mãe-mulher-professora será conceito trabalhado em livro em desenvolvimento pela Profa. Daniela Auad, e que contará com a pesquisadora da presente tese como co-autora, a ser lançado em 2022.
} 
dedicação ao trabalho quanto à possibilidade de constituir e cuidar de uma família, se assim o desejar.

Encerrada essa reflexão inicial, foi solicitado ao grupo de entrevistadas que realizassem pesquisas pautadas sobre a creche como locus de direitos das mulheres e das crianças para o aprofundamento do panorama no encontro seguinte.

\section{3 “A PÚBLICA É MAIS O CUIDADO, O PARTICULAR É MAIS O PEDAGÓGICO”: VISÕES DE CUIDADO NA CRECHE}

No momento seguinte, foi solicitado que as participantes pesquisassem materiais que abordassem a creche em termos dos direitos, tanto das crianças quanto das mulheres. Foram debatidos elementos de dois textos trazidos pelas participantes: um artigo que versava sobre o nascimento da Educação Infantil, e outro que, além de apresentar esse mesmo olhar histórico, discutia, também, as abordagens distintas da Educação Infantil no ensino público e privado. Esses grandes temas se desdobraram em outras questões, como a historicidade dos cuidados com as infâncias e as situações de vulnerabilidade social, a serem apresentadas a seguir.

O teor do primeiro artigo, apresentado pela participante Elô, ressaltou como a socialização contribui para que a sala de aula seja locus de democracia, a partir da interação das crianças com os brinquedos "e tudo ao redor dela", parecendo se referir às dinâmicas que a criança passa a participar, construindo sua autonomia. Acrescenta que as melhorias nas creches foram uma luta constante das mulheres e movimentos sociais, que batalharam para que a creche não fosse vista apenas como necessidade, mas como "direito formal que todo mundo tem direito". E enfatiza que “[...] não é só assim: ah, porque eu trabalho eu tenho direito. Não. A criança de certa idade tem que ter esse direito, porque é uma necessidade não só da mãe, mas também dela". As participantes demonstraram concordar com as considerações de Elô, sem manifestar o desejo de acrescentar algo ao quadro exposto. A expressão dessa opinião coloca a interface dos direitos das crianças e das mulheres, que, ao valorizar ambas, sem exclusões ou condicionamentos ao acesso à creche, reconhecemos como reflexão atinente à categoria Imbricações de Cidadania.

A fim de contribuir na exposição da educadora, esta pesquisadora questionou o grupo de participantes sobre o conhecimento do fato de as feministas terem contribuído ao reconhecimento da creche como direito das crianças. Diante da negativa do conhecimento desse fato, Elô se manifesta novamente, apontando as condições de abandono das crianças, 
citando o dispositivo das Rodas dos Expostos, além de pontuar que o acesso à Educação era um privilégio das classes altas, que podiam pagar por esses serviços. As dimensões evocadas pela participante, que recuperam a vinculação da Educação Infantil com grupos subalternizados historicamente, bem como o percurso de mudanças na Educação foram complementados pela pesquisadora, sobre a atuação de movimentos sociais de mulheres que, primeiramente, demandaram e, posteriormente, reivindicaram a qualidade dos serviços educacionais, no que as participantes demonstraram ter conhecimento sobre essas lutas.

Já o segundo artigo debatido pelas participantes discorreu sobre a historicidade da Educação Infantil em Portugal, também ligada ao trabalho das mulheres e às diferenças dos contextos educacionais públicos e privados, em que os primeiros priorizam as questões dos cuidados enquanto os segundos tem um olhar mais voltado para o educar. Dessa apresentação, surgiram questionamentos, tais como "- Como que ela vai começar a trabalhar?" (Participante Larissa); “- Procurar serviço com a criança no colo?” (Participante Sueli). Ao se referir às crianças, a participante Vanusa afirma que “-É direito delas também”. A participante Larissa nos traz outras faces dos direitos das crianças à creche, pela interação com as famílias:

A gente explica que é um direito da criança e não, né, só dos pais, às vezes tá tirando a criança de algum risco. Porque mãe que não trabalha, isso eu penso na minha cabeça, não trabalha e a criança tá aqui na creche, e as vezes a mãe tá ali na praça usando droga, então é o tempo que a gente tem de cuidar deles aqui e eles não estar lá na praça junto, tem essas coisas.

A situação de risco social é complementada pela participante Bárbara: “- Às vezes, o único lugar que existe alimentação é aqui. Não pode olhar só pela mãe". Observa-se a presença da perspectiva higienista debatida nos trabalhos de Kulmann Junior (1999). Em capítulo anterior, o autor tece análises sobre as ações políticas que objetivavam combater os males sociais, regulando assim a sociedade. A noção de vulnerabilidade permeia os olhares de atendimento das creches, assim como já debatido também por Alves (2016), no que toca justamente na suscetibilidade à privação de direitos e oportunidades, provocadas pelas desigualdades sociais. A manifestação dessas vulnerabilidades na creche, de acordo com as participantes, se dá pela possibilidade de acesso à alimentação e à proteção social perante situações que expõem as crianças às violências. Elas não mencionam a creche como instituição educativa, ou a importância da Educação Infantil, restringindo, assim, o seu papel. Isso implica em um olhar questionável e, por esse motivo, situa esse posicionamento na categoria Práticas não constituintes de Cidadania. 
A participante Carmen questiona sobre a mudança da faixa etária das crianças ao adentrarem à escola, o que originou comentários acerca das mudanças sobre as infâncias, dos cuidados e estímulos aos bebês e as relações verticalizadas com as/os adultas/os. Nesse contexto, a entrevistada Carmen faz uma pergunta à pesquisadora, interessante para seguirmos debatendo sobre as faces que a instituição creche adquire perante a sociedade:

“- Maria Rita, você acha que essa questão das mães estarem trabalhando, e de ter a creche para as crianças e tal, influencia em alguma coisa negativa no comportamento das crianças, em questão de ser rebelde, igual eles falam assim '- Criança, hoje em dia, é muito malcriada.'. Você acha que isso influencia? Porque, assim, no caso a mãe que trabalha fica o dia inteiro fora e quer compensar o tempo que não tava com a criança dando um presente, aí acaba com a criança, sei lá, talvez outras atitudes".

Sobre essa pergunta, podemos analisar por dois vieses: o eterno e conhecido "entendimento" que a mãe é a figura mais adequada para a educação das crianças e o padrão comportamental de mulheres culpabilizadas por não se dedicarem integralmente às crianças. Os dois vieses foram debatidos pelos estudos sobre maternidade de Badinter (1985; 2009), e os dois correspondem a Práticas não constituintes de cidadania, pois inferiorizadoras da mulher. O mito do amor materno, socialmente construído, atribui a expectativa de nocividade a quaisquer outros ambientes ou agentes socializadores que não sejam a mãe. Ao analisar o apagamento da mulher, enquanto indivíduo, em detrimento da mãe, se deixa de discutir o conflito do apagamento e da sobrecarga advinda da responsabilidade exclusiva. Badinter (2009) localiza a culpa como sentimento mais recorrente nas mulheres-mães que trabalham, justamente porque as sociabilidades se transformaram, mas não as expectativas sociais tradicionais sobre a maternidade, evocadas constantemente pela filosofia naturalista. Logo, mesmo conquistando o direito ao trabalho, e de executar atividades fora do lar, a mulher que não se dedica exclusivamente ao lar sofre também internamente, inclusive tendo a postura compensatória por meio de presentes, como exemplificou Carmen:

[...] a contradição mais dolorosa reside no íntimo de cada mulher que não se confunde com a mãe. Todas as que se sentem divididas entre o amor pelo filho e os desejos pessoais. Entre o indivíduo egoísta e o que quer o bemestar de seu pequenino. A criança concebida como fonte de realização pode, portanto, revelar-se um obstáculo a esse indivíduo. É certo que, de tanto superestimar os deveres maternos, a contradição torna-se ainda mais aguda (BADINTER, 2009, p.145). 
Dessa maneira, podemos pensar que o baixo prestígio das creches nas políticas governamentais, e na própria sociedade, podem trazer em si a expectativa tradicional sobre a sacralização do lar.

Em expressão antidemocrática, o atual governo e o Ministro da Educação defendem a chamada "literacia familiar", ou homescholling, pautado em argumento semelhante, do qual os pais têm a primazia na educação dos filhos ${ }^{73}$. Essa é uma leitura enviesada acerca da responsabilidade da família na Educação das crianças expressa pela Lei Maior brasileira. Esse é um dos modos nos quais as expectativas sociais que remetem à maternidade vão se remodelando. O fenômeno da politização da maternidade abordado por Meyer (2005) pode ser relido a partir do citado posicionamento governamental. Sempre ligada à manutenção e produção da vida por conta da maternidade, a mulher novamente está no centro da cena, pois é sobre ela que recai o encargo de ajudar as crianças nos estudos. Ao lado disso, lembremos que Meyer (2005) pondera que a politização da maternidade articula outros problemas e processos sociais mais amplos, como é o caso da Educação domiciliar. A politização nesse caso reside em focalizar a relação mãe-criança como um "remédio" aos problemas das desigualdades educacionais. Além de retroalimentar a sobrecarga das mulheres, posicionamentos como o citado desprestigia a escola como instituição, sem focalizar os problemas que afetam a sua qualidade.

É impossível não atualizar o quadro da politização da maternidade sem mencionar os impactos da pandemia do Covid 19 sobre as mulheres-mães e as crianças. Ainda que os encontros formativos tenham se encerrado em dezembro do ano de 2019, é nesse mesmo período que se tem notícia que o vírus Sars-Cov-2 (causador da doença Covid 19) se alastra pelo mundo todo, chegando ao Brasil no mês de março de 2020. Pelo alto poder de disseminação, como medida de prevenção, se estabelece o isolamento social e a manutenção apenas dos serviços considerados essenciais. Houve o fechamento das escolas e uma drástica redução dos demais ramos das atividades econômicas, que impõem novas realidades a todas as pessoas, e no que toca às famílias, são articuladas alternativas como o ensino remoto e o home-office.

A pandemia termina por gerar uma reconfiguração do homeschooling, já que as famílias e as crianças contam com suporte de professores e professoras apenas por meios digitais, que além da sobrecarga de utilização, não são acessados por todas as camadas da população. Ao lado disso, as mulheres seguem com seus trabalhos, contando ainda com um

\footnotetext{
${ }^{73}$ Fonte: https://ultimosegundo.ig.com.br/educacao/2019-05-08/weintraub-defende-ensino-domiciliarem-audiencia-no-senado.html. Acesso em 28/05/2020.
} 
trabalho mental extra, pois ficaram solitariamente responsáveis por subsidiar conhecimentos de que nem sempre dispõem, além de manobrar as preocupações relacionadas ao contágio da doença, distanciamento de suas redes de relacionamento, o trabalho doméstico e a manutenção da sobrevivência. Como medida de apoio foi instaurado o Auxílio Emergencial, benefício cuja cota foi destinada às pessoas desempregadas, ou que não possuíssem vínculo formal de trabalho, às mulheres mães que, além de atender a esses critérios, fossem as únicas responsáveis por suas famílias, o benefício foi concedido em cota dupla.

Não obstante, a importância do isolamento social nesse contexto de crise sanitária, tal situação novamente coloca as mulheres e crianças em outras condições de vulnerabilidade, para além das que já foram descritas pela tese. Isoladas em casa, e mesmo com a construção de uma rede de contato virtual com a escola, o direito à Educação tem se mostrado prejudicado, devido às condições de acesso e manutenção de vínculo com a escola, uma vez que a família, e em especial a mãe, passa a ser o principal suporte para a produção de conhecimento pelas crianças, com poucos ou nenhum meio de corresponder a essa produção. Tal quadro se desenha por fatores como a falta de preparo técnico, dificuldades em lidar com as tecnologias, pouca familiaridade com o formato de aulas on line e falta de internet. Ou ainda, como foi noticiado pelo Portal $\mathrm{Gl}^{74}$, por fatores de ordem ainda mais precária, como ocorreu em Belo Horizonte (MG), onde uma mãe declara sua impossibilidade de auxiliar nas tarefas por ser analfabeta.

A pandemia, simplesmente, escancarou todas as vulnerabilidades sociais brasileiras, e em especial as que tocam as mulheres e crianças. Também, cresceram alarmantemente os índices de violência doméstica no ano de 2020, no qual os canais de denúncia, Disque 100 e Ligue 180, registraram 237.992 até o mês de setembro do mesmo ano. Isso representa um número $32,9 \%$ superior ao número de denúncias apuradas no mesmo período do ano anterior $^{75}$. O que corresponde a uma violação dos Direitos Humanos, porque as vítimas de violência estão confinadas com seus agressores, quadro extremamente grave, pois o lar nunca foi, e continua não sendo um lugar seguro, nem para as mulheres e nem para as crianças.

\footnotetext{
${ }^{74}$ Fonte: https://g1.globo.com/mg/minas-gerais/noticia/2020/06/19/analfabeta-mae-desiste-de-pegarmaterial-da-escola-do-filho-em-bh-por-nao-poder-ajuda-lo.ghtml Acesso em 05/03/2021.

${ }^{75}$ Fonte: www.gov.br/casacivil/pt-br/assuntos/noticias/2020/novembro/denuncias-de-violacoes-dedireitos-humanos-crescem-quase-33-em-2020 Acesso em 05/03/2021.
} 


\section{4 “A GENTE TEM QUE PRESERVAR OS SONHOS E APRESENTAR ESSA REALIDADE": DE QUEM É ESSA RESPONSABILIDADE?}

A proposta desse encontro formativo se apoia no olhar sobre o papel da Educação e a figura da criança na creche. Foram exibidos dois vídeos, que demonstraram como as expectativas de gênero afetam a vida de mulheres e homens desde a infância. A pergunta de partida do debate foi o questionamento sobre se tais expectativas se faziam presentes em sala de aula. A participante Jéssica avalia que...

A gente já discutiu um pouco, né?! Essa questão de gênero, até acho que já
avançamos bem nessa questão de separação de brinquedos, de não usar tanto
rosa e azul, né?! Pelo o que eu observo do trabalho delas, mas elas vão falar
também, não tem mais isso "menino não brinca de panelinha e menina não
pode brincar de carrinho", só que a gente é muito questionada pelas famílias,
porque a gente vem de uma cultura que demonstra isso tudo aí, né?! Até a
minha geração algumas coisas eu não podia fazer o que meu irmão fazia.
Meu irmão fez um carrinho de rolimã rosa pra mim e foi, assim, aquele
absurdo “- Ela vai descer aquele morro de carrinho de rolimã?". Então, a
gente veio dessa cultura, né?! E, aí, às vezes, a gente é muito questionada
pelos pais, até o ano passado teve uma avó da sala da XXXX ${ }^{76}$, que viu o
menino brincando de panelinha e achou aquilo um absurdo. Aí, ela tem que
ter essa noção, esse embasamento para explicar para esse pai que não existe
mais isso, ele não vai deixar de ser menino só porque está brincando de
panelinha. A XXXX até usou um exemplo bacana na época, disse que: “-
Quantos chefes de cozinha são homens?". E, aí, fazendo essa referência com
o vídeo, o que consigo ver do nosso trabalho é que a gente já avançou bem.
Não tanto quanto a gente gostaria, porque ainda tem a separação de levar a
menina no banheiro, o menino, né?! Ainda tem os banheiros separados,
apesar de que são muito pequenos, e acaba que tem horas que vão vários ao
mesmo tempo..., mas, eu acho que já caminhamos bem.

Todas as participantes manifestam estar em concordância com a opinião de Jéssica, contando experiências exitosas já realizadas, denotando a existência de Práticas constituintes de Cidadania, inclusive pela naturalidade do comportamento e das interações das crianças. Ao mesmo tempo, as educadoras abordam a discussão dos preconceitos, e percebem na atuação preconceituosa da família como eventual complicadora, quando do conhecimento de brincadeiras e atividades que extrapolam as "fronteiras" de gênero, como na situação que uma avó manifestou desconforto em presenciar o neto brincando com panelinhas. São em momentos como esse que a figura paterna surge, em manifestação de Prática não constituinte de Cidadania:

\footnotetext{
${ }^{76}$ Omissão pela menção ao nome da participante.
} 
O preconceito vem mesmo das famílias, dos pais e, às vezes, o pai até fica irritado de ver o filho brincando com a boneca, ele não consegue entender que isso pode significar que no futuro, o filho vi estar embalando um filho, o filho vai estar ajudando a esposa a tomar conta do neném. Não significa que por ele estar brincando de boneca, que ele vai virar uma menina. (Participante Luisa - grifos nossos).

É interessante observar que as mulheres - mães, avós - são as pessoas que mais aparecem nos relatos, as que acompanham de perto as crianças na creche-campo, ao lado do corpo docente, composto, nessa creche, por educadoras mulheres, correspondendo às estatísticas de ocupação profissional da Educação Infantil, já mencionadas nessa tese. Contudo, a figura do pai aparece fortemente na socialização de gênero como um interdito, como agente ativo cuja maior preocupação é veicular uma "moral" relacionada à sexualidade, ligada à heterossexualidade como um ideal. Uma interpretação possível remete às produções de Auad (2004; 2006), que debate como as construções de gênero que versam sobre o "ser mulher" e "ser homem" correspondem a pertencimentos que "preveem" a "negação e o distanciamento ao sexo que não é o seu" (AUAD, 2006, p.22). A reação de interdição por parte do pai ao menino que brinca com uma boneca é apenas uma forma da materialização das construções de gênero.

Aprofundando um pouco mais sobre como isso se dá nas práticas sociais, o trabalho da feminista estadunidense Adrienne Rich (2010) localiza a heterocentricidade como principal responsável sobre as maneiras que as mulheres, especialmente as mulheres lésbicas, e suas existências são invisibilizadas em sociedade. Rich (2010, p.19) é enfática em apontar que as desigualdades impostas às mulheres, como "a maternidade em contexto patriarcal, a exploração econômica, a família nuclear, a heterossexualidade compulsória" têm amparo inclusive em legislação e em exposições midiáticas, em um movimento de supervalorização semelhante à doutrinação religiosa. O "aprendizado" da heterocentricidade se dá por recorrentes imposições, ensinadas principalmente por meio de censuras (RICH, 2010), por sinal as mesmas que os homens-pais infringem aos seus filhos e filhas, como é o caso do pai que censura os brinquedos ao menino, em relato da participante Luisa.

Percebe-se, ainda sob o foco do homem como socializador de gênero, que os homenspais podem assumir outras posturas perante os filhos, mas que, mesmo assim, ainda se observa o efeito socializador conservador. A participante Luisa, ao prosseguir em seu comentário, revela que interpelou seu marido diante da censura sobre os brinquedos ao filho do casal, já que esse possui irmãs e se junta a elas nas brincadeiras com bonecas. Luisa avalia que o marido compreendeu que não deveria separar o menino de suas irmãs nesses momentos, 
pois não observa mais os momentos de irritação para com a criança. No entanto, a participante admite que esporadicamente seu marido se manifesta em falas como "- Mas já vai brincar de boneca?". É possível refletir, a partir desse relato, que mesmo quando a manifestação da heterocentricidade é debatida com vistas à desconstrução da segregação das vivências infantis, motivadas pela separação dos brinquedos por sexo, nem sempre ocorrem transformações nas mentalidades, o que se comprova pela manifestação de contrariedade do marido de Luisa. Isso reforça a necessidade de ações sistemáticas assumidas de modo coletivo, como apontado em dissertação de Mestrado de Ramos (2016), que coloca como um possível caminho a articulação de uma política pública rumo à igualdade de gênero.

Dando prosseguimento à discussão, as participantes foram questionadas sobre as atitudes das crianças e às relações de gênero. As participantes foram unânimes em afirmar que não observam atitudes em que as crianças façam diferenciações por brinquedos ou brincadeiras de um sexo ou outro, citando exemplos de atividades e brincadeiras compartilhadas, realizadas no cotidiano da creche. Outro comentário ligado a uma possível reconstrução das relações de gênero foi socializado pela participante Carmen, que argumentou ser favorável ao compartilhamento de responsabilidades com a família por parte de mulheres e homens, destacando “-É o que eu aprendi. E se você não ensinar para seu filho, a lavar uma vasilha, ele que vai casar e vai ajudar como esposa dele? [...]. É o que eu falo para minhas crianças". Já a participante Larissa opina, a partir de seu contexto familiar, que "- Muitas meninas não fazem e os meninos fazem. Parece que está invertendo um pouco das coisas, as meninas estão mais relaxadas e os meninos estão tendo assim mais compromisso de fazer as coisas em casa”. Essa fala ilustra a resistência social que perpassa as atividades dos cuidados em todo o mundo.

Assim como Hirata (2016), Faur (2014) pontua que tal resistência, muito forte nos países da América Latina corresponde ao ideal tido como "universal" que situa a mulher como principal responsável nessa tarefa. Nos países latinos, Faur analisa que tal quadro se agrava, pois tal visão é acompanhada por modelos de políticas sociais e de sistemas de direitos que preveem que a mulher se ocupe integralmente das tarefas dos cuidados de crianças e de pessoas idosas, de preferência de modo integral, desconsiderando a realidade social que as impele ao mercado de trabalho, formal ou informal, relegando-as como "trabalhadoras secundárias".

Esse entendimento, amplamente difundido no imaginário social, se ampara em dois eixos, conforme Faur: na ineficácia do Estado em prover espaços públicos de cuidados, não 
cumprindo o seu papel de corresponsável, e a inabilidade de pais e mães em concretizarem a corresponsabilidade. Sobre o primeiro eixo, a autora é enfática em apontar que muitas famílias precisam elaborar estratégias para conciliar as demandas do trabalho e a responsabilidade dos cuidados com as crianças, sem contar com alternativas disponibilizadas pelo Estado, o que acarreta uma perpetuação da pobreza, tendo em vista que as classes baixas são as que mais sofrem esse impacto. A esse respeito, Faur (2014, p.5) assevera que "a política pública tem a responsabilidade de oferecer opções para as famílias decidirem o que maneira de organizar o cuidado de meninos e meninas. A estrutura analítica é os direitos humanos". Além disso, Faur nos revela outra faceta dessa desigualdade. A autora observa que todo debate identificado como progressista esbarra com pautas culturais, o que nos leva ao segundo eixo em questão. Constitui um grande desafio "superar uma ideia maternalista que coloca as mulheres como responsáveis em atendimento exclusivo e expandir direitos e responsabilidades para os homens" (FAUR, 2014, p.9), para além das fronteiras de gênero. Os cuidados são (ou deveriam ser) obrigação e direito de todas as pessoas, considerando que as crianças nascem em ambientes familiares dos mais diversos, com mães e pais, ou mães e mães, ou pais-pais, e outras pessoas também. Desse modo, Faur (2014, p. 3) aponta que "as mulheres não exigem cuidados por capricho".

Como caminhos a serem pensados, Faur situa o papel das legislações trabalhistas, que vem sendo repensados em toda a América Latina. As licenças maternidade e paternidade e os espaços públicos de cuidado têm sido uma mudança na organização dos cuidados, que precisam ser pensadas em um âmbito de políticas articuladas e integradas, em qualidade e acesso sem discriminações (FAUR, 2014). Entendemos que a Educação, nos debates nas escolas, pode vir a contribuir nesse equilíbrio e, principalmente, na superação do entendimento de que "as meninas estão mais relaxadas e os meninos estão tendo mais compromisso", pois se o tema Gênero e Direitos Humanos fosse apropriado pela sociedade, o entendimento seria o de que está havendo uma reconstrução da sobrecarga histórica dos cuidados às mulheres, quando os homens se ocupam das tarefas domésticas. Apenas está se fazendo uma justiça na divisão de tarefas. Esse obscurecimento é mote de Prática não constituinte de Cidadania, pois corrobora uma situação de cidadania incompleta.

Tão importante quanto conceber o cuidado como responsabilidade social, é a compreensão trazida pela participante Carmen. A participante coloca que a dimensão dos cuidados se liga à manutenção da vida também em contextos individuais, ou seja, o cuidado de si. Tal opinião foi compartilhada por muitas participantes, ainda que localizando a família 
como esfera socializadora principal, não fazendo referências a outros entes também responsáveis.

\begin{abstract}
Eu acho que tudo é parte da nossa família, se a família ensinar, vai aprender, se a família não ensinar, não vai aprender. Ainda que essa pessoa não queira casar e se a pessoas for morar sozinha para estudar, passou num concurso em outra cidade... Não vai ter mãe, pai para fazer, vai ter que passar roupa. Dependendo da área, tem que chegar lá arrumadinho, tem que estar pronto, aí se você não sabe fazer, você vai voltar “- $\mathrm{Ah}$, não, porque não estava assim, não estava alinhada."? Aí, você vai perder o emprego por conta disso? Você vai ter que aprender de um jeito ou de outro, melhor você aprender na família, se você não aprender na família, você vai aprender no mundo de um jeito muito pior.
\end{abstract}

Sobre o cuidado de si, Sueli emenda os benefícios da socialização dos cuidados para além dos entendimentos conservadores de gêneros que colocam a mulher como responsável. Amparada em exemplo familiar de participação ativa de um primo nas tarefas de cuidado desde a infância, Sueli argumenta que os cuidados com os irmãos menores e o compartilhamento das tarefas domésticas com a mãe contribuíram para que, já adulto, o citado primo não enfrentasse dificuldades quando foi morar sozinho em outra cidade. A participante acrescenta que tal bagagem foi, nessa ocasião, socializada com colegas que não compartilhavam de saberes relativos aos cuidados com o lar, e ainda, o qualifica como pai presente, afetuoso e responsável atualmente.

Deste modo, pode-se visualizar por esse relato, como é possível, a partir de reorganização do cuidado mencionada por Faur (2014), construir na prática outros patamares de envolvimento na responsabilidade de cuidar e educar, fazendo cumprir os direitos das crianças em serem cuidadas e educadas por outras pessoas além da mãe. Logo, está posta a fundamentalidade da interação com outros modelos de comportamento, que ultrapassem as lógicas conservadoras das relações de gênero relacionadas ao cuidado e à educação. Pelo comentário da participante, quando essa lógica é superada, há benefícios para todas as pessoas, inclusive aos homens, o que nos leva a classificar esse comentário, por seu caráter democrático, como Imbricações de Cidadania.

\title{
4.5 “SÓ NÃO ACHO QUE PRECISA FICAR FALANDO": CONTRADIÇÕES PARA PENSAR
}

Visando sistematizar os conhecimentos veiculados nos encontros formativos, a proposta desse momento final de pesquisa contou com em discussão baseada em palestra 
ministrada pela escritora nigeriana feminista Chimamanda Adichie, intitulada $O$ perigo de uma história única.

Esse material foi selecionado, porque o conteúdo principal versa sobre as construções das representações e significados pelas interações sociais, e seus efeitos nas vidas das pessoas. Esse foco permite uma reflexão sobre as relações de poder, as expectativas sociais, as construções simbólicas intrínsecas nas práticas, envolvendo os racismos, preconceitos e estima social, dentre outros eixos correlatos. Como tais questões se difundem pela linguagem, costumes e preconcepções presentes nas construções sociais, que se difundem num amplo movimento de Educação, o intuito do debate é estabelecer pontes com as realidades e práticas na instituição creche, nas interações com as crianças e as mulheres.

Após assistirem ao vídeo da palestra, a primeira observação das participantes foi o reconhecimento de prática de rotulação das pessoas, sem ao menos conhecê-las, “- Sem saber se é verdade ou não" (Participante Sueli), fazendo relações com o foco central da "ideia única" debatida por Adichie. A construção de rótulos aos quais as participantes se referem nos remetem aos escritos de Louro (1997) sobre os marcadores sociais, nos quais as categorias gênero, etnia, raça e classe têm grande projeção nas construções sociais, em nome do que comumente se concebe pelas diferenças, elemento também debatido pelo trabalho de Bichara (2016), sob o slogan da diversidade. Assim como Bichara (2016), Louro (1997, p.51) pondera que as diferenças estão "sempre implicadas em relações de poder, a diferença é nomeada a partir de um determinado lugar que se coloca como referência", cujo caráter se revela, sob o olhar político, na produção das múltiplas desigualdades. Essa dinâmica, pela compreensão da entrevistada Carla, “- Pode edificar ou destruir também a pessoa”. Logo, a rotulação de pessoas, mencionadas por Sueli, tem papel ativo, por meio da socialização. Se a socialização ocorrer de maneira irrefletida, as marcas sociais se configuram nos estigmas (CAVALLEIRO, 1986), impressas às crianças, inclusive na creche ou escola.

Mediante pedido de colocarem mais detalhes sobre como a creche lida com as "ideias únicas", a participante Larissa faz o seguinte comentário:

É difícil, porque quando vem para gente só vem assim, pai, mãe, como se fosse a certidão de nascimento, a idade, tudo assim. Não é uma coisa especificada. Assim, se está bem, se está isso, se tem ou não tem, porque, às vezes, os próprios pais e mães mentem na hora de fazer a ficha. Aí, a gente vai descobrindo depois assim, que não está casado, que não é assim...Eu tenho meninos lá na sala que estão nessa fase, a mãe deixa com a avó, o pai tem outra que já está grávida, já tem outra família e já tem outro neném. Então, as crianças não sabem ao certo, reconhecem pai, mãe, avô e avó, mas o contexto, eu creio que eles estão bem distorcidos, nem dá vontade de 
conhecer, porque, assim, a gente fica com pena. Mas, eles ficam, assim: “Tia, eu tô na casa da minha vó, não sei se minha mãe vem, não". Aí, assim, "- Mas, a namorada do meu pai tá grávida, vai ganhar neném". Entendeu?! Então, assim, o contexto de família para essa criança eu creio que seja aquele contorno total, a mãe, o vô, a vó, a namorada e o pai...e o neném que vem né, é isso tudo não seria só o pai e a mãe, o contorno [...] não é igual a gente foi acostumado.

A princípio, pensou-se, pelas considerações iniciais de Larissa, que a participante sentia-se pesarosa por uma criança, pelo fato subentendido de que a mesma se encontrava afastada do convívio com a mãe. Contudo, ao nos concentrarmos na justificativa de seu posicionamento, a participante menciona o contorno familiar, delimitado pela percepção tradicional e heterossexual de família, o que reconhecemos como uma Prática não constituinte de Cidadania, pois privilegia apenas uma configuração familiar possível. Percebe-se, nessa justificativa, a preocupação com a coesão familiar, valor tradicional debatido por Badinter (2011), argumento geralmente sustentado (não por essa tese) pelo amor, auxiliado pelas preocupações relacionadas à família desajustada, percepções identificadas por Kuhlmann Junior (1998). Para além da culpa e dos conflitos que pairam sobre as mulheres em se dedicarem a outros projetos e ideias que não a maternidade exclusiva, elementos já analisados na tese, essa concepção conservadora, enfocado em núcleo normativo de família, infelizmente é muito difundida e admitida como única possibilidade de bem-estar à criança. Deste modo, é digno de reflexão que as ideias naturalistas e essencializadoras não afetam somente as mulheres, mas também as crianças.

Com relação a elas, uma frente de atuação muito forte, além da medicina, está na área jurídica. Além da monstruosa Lei da Alienação Parental, que tende a proteger pais agressores e negligentes, pois colocam as mulheres que querem resguardar as crianças de situações de abuso como alienadoras (THURLER, 2010) ${ }^{77}$, a área jurídica brasileira vem se utilizando de outra "teoria" utilizada, sem comprovações científicas suficientes. Trata-se da teoria da Constelação Sistêmica Familiar, ou em termos mais comuns, a Constelação Familiar. Essa abordagem, a princípio desenvolvida como método terapêutico, de modo geral, enfoca a resolução de problemas do meio familiar com o objetivo de promover a conciliação das partes nos processos nas varas de família ${ }^{78}$. O que parece de fato ocorrer nessa prática é o reforço da

\footnotetext{
${ }^{77}$ Fonte: https://www.cfemea.org.br/index.php/colecao-femea/375-numero-167outubronovembrodezembro-de-2010/2852-aprovacao-da-lei-da-alienacao-parental-o-que-significa. Acesso em 03/08/2020.

${ }^{78}$ Fonte: https://g1.globo.com/bemestar/noticia/constelacao-familiar-tecnica-terapeutica-e-usada-najustica-para-facilitar-acordos-e-propagar-cultura-de-paz.ghtml. Acesso em 03/08/2020.
} 
ideia da família tradicional, de preferência alicerçada pelo casamento. No que compete à tese, esse reforço é antidemocrático, pois além de sacralizar as obrigações da mãe e do pai como suporte familiar, reforçando as relações de gênero, ao privilegiar os laços de sangue e delegar aos laços sociais e institucionais um status secundário, fica prejudicado o entendimento da corresponsabilidade, o que só faz confirmar socialmente que somente a família em termos biológicos possui a estrutura adequada ao bem estar e segurança das crianças, correspondendo a um retrocesso.

Ainda debatendo sobre as famílias, as entrevistadas mencionaram a insegurança em como se referir às pessoas LGBT (mãe, pai, tia, tio etc.) e informam que a orientação da creche é, simplesmente, respeitar. A partir desse exemplo, as participantes foram questionadas sobre como elas dialogam com as crianças sobre as famílias, ao que Carmen respondeu:

Sobre o negócio das duas mulheres, a gente respeita, tem que respeitar, mas não foi assim que gente aprendeu. A gente respeita, mas sabe quando parece para você que você está ensinando errado, o que isso? Pra mim família não é isso, eu tenho dificuldade de conversar isso com as minhas crianças, porque eu acho... E, se for para eles aprenderem aqui na creche comigo, eles não vão saber disso. Eu $\mathrm{XXXX}^{79}$, não ensino isso para eles, se eles... Porque, na minha turma aos 3 anos ninguém tem essa curiosidade. Eu aprendi porque a família deles, das minhas crianças era pai, mãe e os irmãos, não tinha essa coisa de duas mulheres, dois homens... Se daqui pra frente chegar para mim e eu tiver uma turma de 3 anos e eles tiverem a curiosidade de perguntar, eu posso até falar, mas eu não falo isso com as minhas crianças, quando eu falo alguma coisa de família eu falo "- Seu pai, sua mãe, seus irmãos", a gente conhece as crianças que a gente tem, mas para mim é difícil falar sobre isso. Respeito, eu também tenho parente que é, tenho, entendeu?!

Sobre esse posicionamento, consideramos pertinente retomarmos uma pergunta formulada por Badinter (2011, p. 165): "Como escapar ao aprisionamento materno quando ele é objeto de um poderoso consenso social?". Além da fundamental necessidade de discussões sobre as relações de gênero na Educação na formação docente, como já debatido por Ramos (2016), Auad (2004). Kishimoto (2002) e outras autoras mencionada na tese, há ainda o componente da subjetividade das professoras que perpassa suas posturas e práticas em sala de aula. Essa é uma tensão que é presente, e que é vigorosa quando fazemos a reflexão sobre as visões distintas sobre a reconstrução das sociedades, como nas propostas feministas e de outros movimentos a que almejam a justiça social. Retomando os escritos de Zeichner (2008), que disserta sobre a formação de professores para a justiça social, o pano de fundo que afeta professores e professoras é bastante fragmentado. Envolve questões como "o baixo status da

\footnotetext{
${ }^{79}$ Omissão do nome da participante.
} 
formação de professores em muitas universidades, a falta de incentivos [...] e a falta de competência entre os formadores de professores" (ZEICHNER, 2008, p.21).

Um entrave à promoção de uma educação que fomente as mudanças sociais, identificado por Zeichner (2008), é a falta de esclarecimento sobre o que se entende por justiça social, pois os sistemas de ensino demonstram sensibilidade a abordagens que dialoguem com as realidades sociais de alunas e alunos. Mas o que de fato se observa, em muitos países, que tais abordagens são transmitidas de maneira suplementar na formação docente. Ocorrendo, assim, uma redução do currículo formador. De maneira desprestigiosa, análoga ao que ocorre com as disciplinas do currículo de formação de professoras e professores, o trabalho docente nas escolas também se depara com o currículo reduzido, pautando-se por metas voltadas às avaliações de desempenho focadas em disciplinas específicas, o que configura-se como uma contradição.

Outro obstáculo identificado por Zeichner (2008) é o de que, apesar de as categorias gênero e raça serem temas que foram visibilizados na formação docente sob a agenda da justiça social, a pura e simples leitura sobre esses temas nos momentos de formação nem sempre correspondem à condução um trabalho efetivo e comprometido com a perspectiva da justiça social por parte de professoras e professores, pois nem todas lecionam ou têm contato com escolas heterogêneas, do ponto de vista de segregações pela pobreza e outras desigualdades sociais.

Logo, é passível de questionamento, a partir de comentário da participante Carmen, como é possível debater os olhares relacionados à maternidade e à família, se é algo que, além de admitido como cristalizado socialmente, não consta como elemento curricular na Educação Infantil? O próprio Zeichner (2008) nos fornece uma pista importante, ao mencionar a falta de definição sobre a justiça social. Assim como a diversidade, o termo slogan já debatido aqui em outros momentos, a justiça social pode ser facilmente tomado como um slogan, sem a devida reflexão e localização do que se entende por desigualdade social. Tal lacuna obscurece também sobre quais agentes deveriam atuar nesse sentido, pois ao não se delimitar tal compromisso, que entendemos ser de toda a sociedade, é injusto, e impossível, que o trabalho docente lute solitariamente contra as desigualdades sociais.

No que toca às crianças, ainda que contempladas pelo direito à Educação, as falas das participantes parecem indicar que a formação, deficitária dessa questão em nível macro, terminam por não tocar em debate significativo sobre as conformações de família, o que também é uma Prática não constituinte de cidadania, pelo silenciamento. Entende-se que, ao 
não se representarem como pauta de debate junto às crianças, os seus direitos a uma Educação, do ponto de vista humano e social, sejam precarizados também, ainda que isso faça parte do cotidiano ou do entorno delas.

Acrescentando opinião ao mesmo debate, a participante Larissa faz uma distinção que parece se afinar com os reflexos sobre a mencionada redução curricular, tanto nos cursos de formação docente quanto na própria creche: “- Agora, no momento, o que a gente tem que fazer é respeitar, a gente não pode opinar, a gente não pode opinar em nada, chegou, a gente tem que aceitar, porque para gente é difícil, mas tem que ser".

A reticência observada nesse, na forma de "- A gente não pode opinar.", foi apoiada por todo o grupo de participantes, que concordaram com os termos da participante. Foi reconhecido pelo grupo que os debates sobre as realidades sociais que estão presentes na creche dizem respeito a foro íntimo, confirmado pela participante Sueli: “- Porque a opinião da gente, você não pode contar aquilo para a criança, ele tem que resolver isso em casa". Além de equívoco teórico, pois tanto a literatura quanto a legislação evocadas nessa tese apontam sobre a construção da democracia e da cidadania na infância (KRAMER, 1989; OLIVEIRA, 2011) e a importância da mediação docente nesses processos, nas relações com o mundo, ou seja, em dimensões micro e também macro, o reducionismo representado pela responsabilização exclusiva da família em apresentar referências de mundo às crianças é reflexo da influência dos discursos conservadores sociais e políticos que, inclusive, constam, como já exposto, no Plano Municipal de Educação de Juiz de Fora (MG), no qual há orientação expressa sobre essa questão. Observa-se mais um desafio à promoção de uma educação que emancipe as mentes para além do seio familiar, redundando em uma Prática não constituinte de Cidadania, pela limitação do conhecimento e, também, da complementaridade do papel da escola.

Cabe acrescentar que o desmerecimento dos direitos das mulheres, além de expô-las a muitas desigualdades sociais e discriminação de gênero, as invisibiliza também como seres humanos que são. Sobre o componente do cansaço e da sobrecarga materna, no que toca ao trabalho mental para com a responsabilidade e a manutenção das necessidades das crianças, a visão da participante Lu indica essa desumanização: “[...] porque eu tenho minhas irmãs que têm filhos e eu penso, às vezes, que ela tá cansada, só que eu penso que você, eu acho que você não precisa de ficar falando". Ainda que esse comentário tenha se dado a partir de um relato feito por outra participante, em defesa de uma criança que era tratada com pouco 
acolhimento em virtude de seu comportamento agitado, ao mesmo tempo, que a participante acolhe a criança, silencia sobre as angústias que ocorrem às mães.

Não se trata de justificar quaisquer condutas familiares que menosprezem a criança, ainda mais quando esse menosprezo é feito diretamente a ela, o que é muito grave, mas de pensar sobre o "outro lado" da maternidade, geralmente negligenciado pela sociedade. Esse outro lado, que diz respeito às dificuldades e os sentimentos ambivalentes foram explorados por Donath (2018) e também por Badinter (2009, p. 22) coadunam-se no seguinte aspecto:

\begin{abstract}
A futura mãe fantasia apenas o amor e a felicidade. Ela ignora a outra face da maternidade feita de esgotamento, de frustração, de solidão, e até mesmo de alienação, com seu cortejo de culpa. Quando lemos os recentes testemunhos de mães, avaliamos o quanto elas estão pouco preparadas para essa conturbação.
\end{abstract}

A questão dos processos envolvidos na maternidade, em especial as situações desgastantes ou conflituosas, não podem sequer ser mencionadas, pois rechaçadas socialmente. Qualquer demonstração de insatisfação remete à figura de uma mãe má, em uma leitura de um "egoísmo materno" (BADINTER, 2009). Isso se afina com o desconhecimento sobre a maternidade real, apontado por Badinter (2009, p.23) como um risco real, bem distante das construções ligadas à realização e plenitude das mulheres, pois muitas vão experenciar "uma felicidade e um benefício identitário insubstituíveis", enquanto outras tentarão conciliar as exigências sociais, ao lado daquelas que "jamais confessarão que não conseguem, e que a experiência materna delas é um fracasso". Esse é um dos muitos consensos sociais baseados em naturalismos em que, novamente, em nome do amor, a mulher é, no discurso, glorificada como mãe (BURMAN, 2009), mas na realidade concreta, é apagada, pois é sempre vista como um apêndice à figura da criança. Ainda conforme Badinter (2009, p.78), é “consenso frouxo e difuso que está a ponto de se tornar nossa ideologia dominante, apesar da constante crítica do maternalismo por parte das feministas históricas francesas". Prova disso foi a colocação da participante Carla, que pontuou que "- Igual à gente que é casada e tem filho, você não pode colocar também só o seu filho na frente não, você tem que saber separar", referindo-se à existência de outros olhares, como a mulher-mãe ter outras prioridades de vida, além das/os filhas/os.

Ainda que seja uma constatação óbvia aos olhos dos Feminismos, quando se trata das crianças, a interação em outros ambientes além do lar ainda é terreno controverso. A participante Carmen questionou a opinião do grupo sobre as razões das famílias se preocuparem muito em ocupar o tempo ocioso das crianças com atividades extracurriculares. 
As opiniões se dividiram em questões como: a) a sobrecarga da criança ("- Se nós adultos, a gente fica cansado com a nossa rotina, eu fico imaginando a criança que tem várias coisas para fazer. Como que dá conta?”); b) a boa intenção da família em promover o desenvolvimento infantil (“- Não, faz falta outra atividade para desenvolver”) e c) a intencionalidade de "cansar" a criança, em um esquivo das obrigações para com elas, gerando a falta de interação familiar ("-Mas os pais fazem isso para cansar a criança, tipo assim deixa eu chego cansado, deixa eu cansar ele, só que ele não tem contato com filho"). Baseadas nas emoções emitidas pelas participantes em suas colocações, as classificações sobre a maternidade, quando estas procuram atividades extras para as crianças, foram: a) mãe insensível ao bem-estar físico da criança; b) mãe zelosa que promove o desenvolvimento; c) mãe egoísta. Essas impressões conduzem à pergunta formulada por Badinter (2009, p. 177), a qual retomamos: "escolher ser mãe ou não deve ser analisado em termos de normalidade ou de desvio?".

Tal pergunta é pertinente à discussão das participantes uma vez que novamente se revelam as inúmeras interfaces entre as crianças e as mulheres, bem como as suas contradições, que criam polarizações sobre a mãe boa e a mãe má, ou egoísta. A primeira ideal, desejável, enquanto as que fogem ao modelo, desprezadas socialmente. Mesmo não mencionando o conhecimento dos propósitos pelos quais as mães colocam as crianças em atividades extracurriculares, ocorrem julgamentos de valor, de modo precipitado sobre a maternidade. Reconhecemos como precipitados, pois Badinter (2009) discorre sobre os distintos elementos constituintes da maternidade, e que comumente são desconsiderados, como: os pesos das normas culturais, a depender da cultura de cada parte do mundo, o acesso à educação, e a situação socioeconômica. As questões citadas exercem influência nos modelos de maternidade predominantes, que variam com o tempo, o que nos permite aludir que essas mesmas variações sejam responsáveis pela ausência de um consenso sobre o que se deve ponderar ou priorizar na decisão de propor atividades extras das crianças. É curioso observar como tal questão parece permear não só o ambiente doméstico, mas também um ambiente de Educação profissionalizado. $\mathrm{O}$ espaço da creche possui muitas expectativas sociais conservadoras relacionadas às mulheres-mães, socializadas pelas participantes, o que denota a ausência de acesso a debates feministas.

Talvez sejam as distintas concepções acerca da maternidade que permitem que essas iniciativas voltadas às crianças tenham olhares tão distintos, ainda que, sem desgastes para as crianças, as atividades extras se revelem benéficas para a saúde, produção de conhecimento e 
interação social. Esse tipo de entendimento, nesse caso específico, penaliza tanto as mães, quanto as crianças. As mães são penalizadas, além da histórica subordinação às crianças, a partir de uma série de contradições, como o julgamento sobre as escolhas da educação das crianças, e a culpa sobre a conciliação entre realização familiar, repertório de vida concreta e realização pessoal. Com isso, as crianças também sofrem uma penalização que as limitam em seus direitos, pois a oportunização em enriquecer sua educação e desenvolvimento, seja ele cognitivo, estético, cultural ou social fica condicionada a uma ideia que se atrela a um suposto abandono da mãe. Logo, mulheres e crianças são vulneráveis e diretamente atingidas pela superficialidade com que a maternagem real é encarada.

Prosseguindo o debate, foi realizada uma intervenção, por parte da pesquisadora, sobre a conjuntura geral das questões que envolvem a maternidade e os cuidados e educação das crianças às participantes (cobranças sociais, idealizações sobre as mulheres e crianças, distintas realidades e propósitos de vida e de educação, entre outros), com o intuito de saber se as participantes se reconheciam como pessoas distintas dos perfis de mulheres mencionados por elas. Todas as participantes reconheceram que: "não!". A partir dessa manifestação, a pesquisadora prosseguiu sua explanação, e a partir de socialização de relato em que foi exemplificado a maneira com que mães se sentem pressionadas a zelar em todos os sentidos pelas crianças, a participante Sueli questiona: “- No mínimo, deve ser separada, isso é coisa de homem, não é?!”. Novamente a dominação masculina se faz presente na socialização de gênero, já que a ação dos machismos direcionam, de modo autoritário, mas sutil, as mulheres à submissão, na forma das expectativas sociais, inúmeras, mas especificamente acerca da incumbência exclusiva para com a maternagem, o que se distancia de prescrição legal.

A feminista estadunidense bell hooks (2013) é referência na questão sobre a problemática situação da falta de reconhecimento de classe que acomete as mulheres, identificada nos julgamentos das professoras, que mesmo se reconhecendo como mulheres, se distanciam como mulheres das mães das crianças da creche, como ocorrido na situação das atividades extraclasse. A chamada irmandade feminina, como apontado por hooks (2013), é ideal feminista ainda distante de se concretizar. Essa dificuldade tem suas raízes nos regimes escravocratas, mais precisamente nas heranças das relações de senhora/escrava, em que as mulheres brancas se sentiam preteridas sexualmente por seus maridos às mulheres negras que, em contrapartida, não encontravam nenhuma solidariedade por parte das mulheres brancas pelas violências sexuais que eram desferidas pelos homens (hooks, 2013). 
Ainda que com alguma proximidade pessoal, as mulheres brancas reproduziam as condutas de violência e de invisibilização às mulheres negras. E o que se iniciou no âmbito doméstico, por tantos anos, perdura ainda nos tempos atuais. Mesmo que muitas mulheres brancas e feministas reconheçam o apagamento da mulher negra, considerando importante debater as questões dos privilégios e da real dificuldade de concretizar alianças entre as mulheres negras e brancas, hooks (2013) assevera que esse como outro fator dificultador, também herdado do apagamento. A postura mais frequente no meio acadêmico é o contato com mulheres negras como fontes a serem consultadas sobre os temas que as afetam, como o racismo, a objetificação, dentre outros. Isso reforça a ideia separatista, em outra roupagem da relação de trabalho servil de senhora/escrava: uma estuda, numa produção ativa de conhecimento, enquanto a outra é o objeto, o que inviabiliza uma construção conjunta e o estabelecimento de laços, pois uma serve e a outra é servida.

A feminista e professora hooks (2013) tem como grande inspiração os escritos do mestre Paulo Freire ${ }^{80}$, que, ao ponderar sobre os aspectos da educação bancária desumanizada e desumanizante, pois de caráter paternalista - situa os aspectos de reconhecimento das relações entre opressores e oprimidos como primordiais à busca pela libertação humana, que conscientiza e politiza, pela via da Educação. Ao refletir sobre as estruturas da dominação no livro Pedagogia do Oprimido, Freire (1987, p.27) se aprofunda nas raízes sobre a falta de consciência de classe, na forma da "dualidade existencial dos oprimidos que, "hospedando" o opressor cuja "sombra" eles introjetam", são ele e, ao mesmo tempo, são o outro". E é quase sempre certo, ainda conforme Freire (1987), que não se reconheça concretamente o opressor, tampouco a "consciência para si", pois a imersão nas situações de opressão são frutos de conjuntura histórica e sociológica, o que se afina com a escassez das relações solidárias entre as mulheres, enquanto classe. Logo, outra manifestação de Prática não constituinte de Cidadania.

Ainda que nenhuma participante tenha se colocado enquanto mulher negra, as análises de hooks (2013) sobre a falta de irmandade entre mulheres negras e brancas são potentes para pensarmos como esse mecanismo atua, mesmo quando a categoria raça não é mencionada, na

\footnotetext{
${ }^{80}$ Ainda que, com todo o devido mérito, Paulo Freire seja considerado precursor da Pedagogia Crítica, existe uma crítica significativa por parte das feministas sobre o sexismo presente em suas obras, o que é uma contradição à uma educação transformadora. No entanto, a postura de Paulo Freire, em tanto admitir essa lacuna, quanto em buscar superá-la em suas obras posteriores, levou hooks (2013) a compreender que as contradições são parte do aprendizado, "parte daquilo que a pessoa deseja mudar - e essa luta, por vezes leva tempo" (hooks, 2013, p.80). Sua compreensão é pertinente ao debate democrático defendido pela tese, na qual entendemos que nossas contradições e diferenças não devem superar a nossa capacidade de fazer alianças e construções conjuntas.
} 
maneira com que as participantes, mesmo sendo mulheres, algumas sendo mães, e outras não, demonstram desconsiderar os motivos pelos quais as mães das crianças colocam as crianças em atividades extraclasses. Para além das preocupações com o futuro educacional ou vida adulta, outras razões conhecidas das mulheres não são sequer lembradas, como a conciliação dos cuidados com as crianças com a jornada de trabalho, ou a proteção à violência, e até mesmo à pobreza.

Grande parte da população e de movimentos sociais sinalizam e reivindicam aos Estados brasileiros a implantação de espaços culturais e de lazer, inclusive existindo iniciativas de utilização dos próprios espaços escolares, aos finais de semana, com a finalidade de promover a interação das escolas com a comunidade e uma cultura de paz (SASTRE, 2011).

Definitivamente isso não equivale ao abandono ou se livrar de um fardo, mas de conscientizações e preocupações ligadas às tensões entre a vulnerabilidade social e o desenvolvimento saudável das crianças. As mulheres, ao cobrar o posicionamento das políticas públicas a serem promovidas pelo Estado, tencionam um debate de direito delas mulheres-mães, em maternar de modo compartilhado - mas também o direito das crianças à proteção social e educação, em contar com uma rede de apoio de modo público, na ausência ou impossibilidade de provimento por parte da família.

Ainda que as participantes, nas falas seguintes, demonstrem compreender e apoiar as mães das crianças de suas turmas em situações classificadas como difíceis (como em relato de Larissa, sobre uma mãe contrariada por um remédio caro ter derramado na mochila de uma criança), o distanciamento das participantes e das mães, enquanto mulheres, novamente se manifesta. Em um questionamento feito acerca da opinião das participantes sobre o regime das creches noturnas, a participante Raquel responde: “- Olha, se tiver isso aqui, eu acho que aí que as mães vão largar mesmo as crianças, só vão aparecer aqui uma vez por mês e olhe lá".

É realmente muito triste que ainda perdure o entendimento de que a criança na escola, usufruindo do seu direito à Educação, ainda seja concebida como uma criança abandonada, principalmente pela mãe. Além disso, é digna de reflexão que os horários das creches, histórica e concretamente, não atendem à jornada de trabalho das mães. Essa motivação é, há muito, apontada na bibliografia da Educação Infantil (ROSEMBERG, 1984; 1994) aqui debatida, na perspectiva dos direitos de cidadania das mulheres, mas cabe ser considerada também à luz dos direitos das crianças. Ainda que a modificação ou extensão de turnos, e a 
adoção da educação de tempo integral também em outros níveis de ensino, seja questão pertinente, pois tensiona a esfera dos direitos das crianças e da organização da família, ainda é encarada com desconforto pela influência das relações de gênero conservadoras, que associam o distanciamento da mãe com o descaso para com a criança, reforçando uma ideia de que o lar é a esfera educativa e cuidadora mais adequada, construção social debatida, mas não superada.

Como fator complicador, o livro "Educação Infantil em jornada de tempo integral: dilemas e perspectivas", organizado pela professora brasileira Vânia Carvalho de Araújo (2015), aponta os problemas relacionados à parcela de responsabilidade por parte do Estado, que entendemos que também concorrem a esse imaginário social, já que um grande entrave é o "descompasso entre a afirmação da qualidade da/na educação infantil com formas precarizadas de atendimento da jornada ampliada" (ARAÚJO, 2015, p.20 ). É questão que envolve recursos, espaços físicos, alimentação, contratação docente, currículo, e a organização da vida como um todo, debate esse que vem sendo aprofundado nas últimas décadas (MOLL, 2012; BRANDÃO, 2012; ARROYO, 2012), mas que sempre foram uma constante quando se trata das creches.

Não se trata somente de olhar as mudanças de turnos como meros anteparos clientelistas com vistas ao mero combate a vulnerabilidade social, mas de nos propor a um exercício de pensar os espaços de educação pautados nos direitos de emancipação das infâncias e das mulheres, na interface entre o diálogo com as realidades sociais, plurais e a corresponsabilidade da família e sociedade, de modo igualitário e democrático. Uma proposição interessante ao escopo da pesquisa é apontada pelo professor Miguel Arroyo (2012), que situa a profícua oportunização de repensar o significado político da escola, no que tange ao direito de usufruirmos a mais e maior educação, pelo direito de termos mais tempo na escola. Esses direitos, segundo o mesmo autor, são o eixo de afirmação dos direitos ao bem-viver, em tempos e espaços dignos.

Logo, as práticas pedagógicas poderiam ser ressignificadas, considerando as questões sociais das crianças e de professoras e professores, em perspectiva ética, ao passo que essa categoria também tem seus fazeres profissionais afetados por elementos sociais, econômicos, políticos e culturais (ARROYO, 2012). Um caminho possível se coloca pela perspectiva da formação de professoras e professores pela justiça social, na qual uma via são as produções feministas, que ao debater as ações e expectativas sobre as mulheres e as crianças reconstroem 
a secundarização social, apontada nas contradições e inconsistências apontadas pelas participantes da pesquisa.

No que compete às mulheres, cabe salientar que o receio demonstrado no comentário de Raquel, em pressupor o abandono das crianças nas creches por expansão dos turnos, pode não corresponder à realidade de muitas mulheres trabalhadoras. As mudanças nas sociabilidades contemporâneas não afastaram as mulheres das responsabilidades com as crianças, pelo contrário. Já foram explanadas as múltiplas, e até oitavas jornadas de trabalho das mulheres (ROSA; FELIPE, 2019), que se sobrecarregam em dar conta de todas as demandas profissionais, domésticas e familiares. É perversa e antidemocrática a maneira com que outros ideais além da maternidade e dos cuidados sejam associados a uma ausência de compromisso com as crianças. Em recente reportagem do Portal G1, sobre o tema das creches noturnas como possibilidade, a opinião das mulheres entrevistadas é unânime em demonstrar que é fantasiosa a falta de compromisso com as crianças e com a família. Na opinião dessas mulheres, trabalhadoras do comércio, em sua maioria, as creches noturnas funcionam como condição concreta de melhorias de vida, ou de manutenção de seus empregos. Questionadas sobre suas vidas caso as creches noturnas fossem uma realidade, além da tranquilidade que isso representa em termos de independência das redes sociais de cuidados, e das onerosas despesas com a contratação de babás, as mulheres declaram que o horário noturno das creches as permitiriam estar com as crianças em casa no período em que elas não estivessem no trabalho ${ }^{81}$.

Logo, se comprova que pouco se sabe sobre as realidades e aspirações concretas das mulheres, sobretudo das mulheres-mães, e muito se conjectura em torno de saberes cristalizados da figura de uma mãe ideal, que, ao se ausentar, é tida como uma mãe má, mediante olhares sociais de referências machistas, como já discutido nesse tópico. Mesmo que essa ausência seja em razão de uma busca por melhores condições de vida para ela e para a criança. Além disso, é direito da criança ser educada desde o nascimento, aspecto esse que, por não ser lembrado, configura um desrespeito ao direito da criança em estar nas creches e nas escolas de Educação Infantil.

Como último movimento dos encontros formativos, as participantes foram convidadas a responder a seguinte questão: “A creche é local de direito das crianças e das mulheres?”. As participantes, de modo geral, reconhecem sim, a creche como local de direito de mulheres e

\footnotetext{
${ }^{81}$ Fonte: https://g1.globo.com/educacao/noticia/2020/02/18/a-polemica-das-creches-noturnas-tiveque-sair-do-trabalho-por-nao-ter-onde-deixar-minha-filha.ghtml. Acesso em 04/07/2020.
} 
crianças, considerando várias questões, que revelam as muitas faces desse instigante objeto de pesquisa.

\begin{abstract}
Nós, mulheres, e as crianças temos direito à creche, sim. Pois para as mulheres a creche é um local de acolhimento e de segurança para a criança onde a mãe pode deixar com a certeza que o filho será bem cuidado para que a mãe possa trabalhar ou resolver os seus afazeres. Para a criança é um excelente lugar, pois tem aprendizado, cuidados, brincadeiras e socialização. (Participante Sabrina)
\end{abstract}

Sim! Com o passar dos anos, a mulher vem adquirindo mais autonomia. A mulher é mãe, pai, trabalhadora e dona do lar. A creche, nesse sentido, vem como um "suporte" para que esta mãe trabalhadora consiga deixar seu filho para que esse seja cuidado. A creche também é um direito das crianças, independente se a mãe trabalha fora ou não. A creche é um local de aprendizagem, cuidado, brincadeiras e socialização, e deve ser ofertado para todas as crianças. Creche é um direito das crianças e da trabalhadora, uma conquista da sociedade (mãe trabalhadora) (Participante Bárbara).

Acredito que sim porque a creche proporciona não só o cuidar, mas o educar, ou seja, a criança tem um desenvolvimento para a vida. As mulheres também, porque através da creche podem trabalhar para mudar talvez a realidade de sua vida ou apenas pode ter um tempo para seu descanso enquanto sua criança está frequentando a mesma (Participante Carmen).

Esses três comentários expressam o olhar com a dimensão concreta da mudança nas realidades de mulheres e crianças, público atendido pelas creches. Todas apontam o que a creche representa em termos de aprendizado, interação e educação para as crianças, e como possibilidade de as mulheres contarem com um apoio para que se dediquem às tarefas cotidianas para além do cuidado com as crianças, mencionando a segurança e a tranquilidade que isso representa. As participantes, ao partirem da concretude da creche como equipamento, colocam, ainda que não, explicitamente, a importância da creche como política pública, cujo dever de disponibilizar recursos, condições e equipamentos para atender à população é de obrigação do Estado brasileiro. Como já exposto em outros momentos da tese, onde existe a creche existe o acesso aos direitos civis e sociais. Outra maneira de olhar sobre o acesso aos direitos civis e sociais pelo público que acessa os serviços da creche se relaciona com o aspecto do acesso à creche:

Sim, é local de todos que têm necessidade de deixar seus filhos para trabalhar, ou mesmo para ter um local onde se sintam protegidos. Toda criança tem direito à creche mesmo que os pais não trabalhem. (acho que os que não trabalham precisam até mais porque podem estar em situação de risco) (Participante Larissa). 
Sim e não. Devido ao grande cuidado que existe com as crianças, no trato, lazer, higiene e psicológico, muitas vezes, o comportamental vem de acordo com o comportamento e a vivência em casa, fazendo, às vezes, com que não seja vista as necessidades das mães. Numa visão geral, a creche é para as mães poderem deixar as crianças para trabalhar, mas nem sempre é assim, outras mães conseguem e ela se desespera por não ter com quem deixar e ter um gasto com escola, cuidador, uma vez que é direito seu. (Participante Eloisa).

Sim, na minha concepção, com certeza, pois em relação às crianças é direito constitucional, mas vai muito além, o respeito, socialização dentre outras coisas que se fosse citar ficaria o dia todo. Quanto à mulher também o direito da criança faz com que a mulher mãe possa trabalhar e saber que seu filho está sendo cuidado, seguro e, também, de ter o direito de participar da vida (rotina da criança). (Participante Raquel).

Os comentários denotam a preocupação com as situações de vulnerabilidade social, distanciando-se do entendimento da Educação como um direito, a ser usufruído pelas crianças. No entanto, não há o que se negar o quanto a creche é potente, para as mães e para as crianças, em concorrer para que haja modificações na situação socioeconômica das famílias, quando as mães conseguem a inserção no mercado de trabalho e quando as crianças passam a ser socializadas e educadas em um ambiente profissionalizado, voltado à sua educação. A creche consolida o direito à educação da criança pequena, e dá condição à mulher-mãe de realizar outros anseios de vida em paralelo à família.

Já outras participantes, paralelamente a essas questões, mencionaram a construção da cidadania pelo trabalho docente:

Sim, a creche como um todo é local de direito da criança, da mulher e da família. Afinal, temos que focar na educação e no bem estar das crianças. Para que garantirmos uma educação de boa qualidade devemos saber do histórico familiar da criança, pois é primordial a presença da família na vida das crianças. As crianças precisam de uma liberdade de expressão, onde as ideias delas são aceitas e respeitadas. Sendo assim, focada a educação infantil. As creches e educadores em geral tem que ter uma visão ampla e segura em relação às didáticas passadas para as crianças no intuito de passar para elas o porquê, do ensino e para que elas tem que aprender e levar para o resto da vida, se socializando e interagindo perante a sociedade. Devemos dizer que o educador, a escola e a família trabalhem juntos. Assim, terão um ótimo resultado sobre a educação das crianças. (Participante Dani).

Sim. Ela é a base para a vida, na creche aprendemos a respeitar a criança, a mulher e a família. Dar suporte é um desenvolvimento para a vida. $\mathrm{Na}$ creche aprendemos a lidar com as diferenças e a olhar para o próximo como ser único com direitos que precisam ser respeitados. Um lugar de 
socialização e de amor por cada ser, uma aprendizagem que se carrega para sempre. (Participante Luísa).

Existem nesses comentários os desafios da formação docente e da parceria com que a família e a instituição creche devam atuar compartilhando a tarefa de educar, de modo complementar. A menção ao compartilhamento, na medida em que não deposita expectativas única e exclusivamente na mãe, já sinaliza a uma reconstrução de gênero relacionada ao cuidado, que pode vir a ser debatida de modo público de maneira a concretizar o entendimento sobre a maternagem, ampliando a dimensão do cuidado como algo social, e não somente doméstico.

Além disso, é mencionado, também, o quão significativo é o contraprocesso ${ }^{82}$ das socializações promovidas na creche. Ao ser apontado o aspecto da interação com as diferenças, a participante indica que há, também, uma ampliação no olhar das professoras para com a pluralidade humana, no que podemos inferir, apoiadas em análise de Tardif (2002), que os saberes docentes se constituem e se modificam, também, pelas experiências do cotidiano. Entendemos que, em alguma medida, assim como apregoa Zeichner (2011), a produção do saber docente a partir das realidades sociais acessadas pode vir a democratizar as práticas de trabalho das professoras, tanto nas escolas como nas creches.

O comentário de Juliana, ao abordar a questão dos direitos de mulheres e de crianças, o faz expandindo sobre os ganhos imateriais que são construídos pelo acesso à creche, o que vai à direção da transformação humana:

Sim, porque é um ambiente em que é acolhedor, onde as mães têm a
oportunidade de sair para o trabalho e também dá essa mesma oportunidade
para as crianças, de se desenvolverem e conhecer novos ambientes para se
explorar e se conhecer, aprender e ensinar com o outro, onde se pode
compartilhar e vivenciar novos ambientes e com o direito de poder ter esse
acesso que é muito importante na vida da criança que irá aprender vários
tipos de coisas que vão ser essenciais para a sua vida, seu crescimento como
cidadão, e para a mulher o direito de poder mostrar para seu filho, e a si
mesma, novos caminhos e conhecimentos, onde o cuidar e ensinar são
também um aspecto da creche.

A participante situa a produção da educação na creche como uma ampla gama de possibilidades às crianças, e aponta, também, a creche como uma via de construção de outras

\footnotetext{
${ }^{82}$ Esse termo inspirou-se na denominação de contramovimento, expressão utilizada para denominar como as ações dos movimentos sociais, ao interpelarem, discutirem e apresentarem outras maneiras de intervir nas realidades sociais, promovem mudanças perante os sistemas político-sociais. $\mathrm{O}$ contramovimento é debatido numa perspectiva feminista nos trabalhos da professora Dagmar Meyer.
} 
existências para as mulheres, parecendo se referir para além das expectativas sociais mais comuns. Essa recriação, por parte de mulheres e crianças, via creche, pode indicar uma maior proximidade com a vivência de uma cidadania plena, o que é o propósito final da organização democrática da sociedade brasileira. No reconhecimento de crianças e mulheres terem seus horizontes ampliados, em conhecimento, formação e oportunidade, a fala de Juliana denota a possibilidade de uma transformação social intergeracional, pela modificação de expectativas de vida das duas faixas de idade.

As contribuições das mulheres participantes dos encontros formativos, formuladas em perspectiva feminista, ao propor a pensar a maternagem na creche, seguem analisadas no próximo capítulo, desta vez, em discussão que abrange a educação e outros aspectos dos direitos para além da creche. 


\section{OUTROS TERRITÓRIOS E CONJUNTURAS DE UM MESMO CAMPO}

Este capítulo aponta outras dimensões e fenômenos ligados à consolidação da maternagem. Remete a elementos úteis e a uma reflexão de construção dos campos de conhecimento debatidos na tese, ou seja, a Educação Infantil e a democracia, numa perspectiva feminista. A partir das impressões das participantes dos encontros formativos que fomentaram diálogos da creche enquanto locus de direitos de crianças e de mulheres, o panorama geral de pesquisa conheceu as principais interfaces que compõem a imbricação desses dois grupos, apresentadas no capítulo 4.

Pensado à luz das mulheres e das crianças enquanto cidadãs, mas também enquanto seres humanos, o presente capítulo se orienta por um movimento de reclassificação das categorias de análise principais - Práticas constituintes de cidadania; Práticas não constituintes de cidadania e Imbricações de cidadania - pelo olhar em suas subcategorias. As subcategorias - Percepção de direitos; socializações igualitárias; resistências conservadoras e práticas conservadoras - surgiram pelos apontamentos "de quem" atua, deixa de atuar ou deveria atuar nas dinâmicas socializadas e apontadas pelas participantes dos encontros formativos. A partir desse diagnóstico, surgiram questões desafiadoras que perpassam a maternagem na creche.

Ao ser elaborada a hipótese de que a Educação poderia contribuir na socialização da maternagem como responsabilidade de todas as pessoas, não se supôs que esse olhar pudesse gerar discussões sobre outros temas, transversais ao objetivo da pesquisa. No capítulo anterior, percebemos que os agentes apontados como atuantes - ativos ou não - das práticas discutidas nos encontros formativos são as crianças, a família, a mãe, o pai, as professoras e os governos. Logo, o panorama desse capítulo propõe reflexões sobre outros fenômenos que compõem um pano de fundo que influencia a atuação dos agentes das práticas sociais mencionados, a partir dos debates na creche-campo.

Tal capítulo nos conduz a uma reflexão sobre a magnitude do campo de pesquisa, pelas interfaces evocadas nas falas das participantes, em temas transversais que conformam a creche como um território em disputa, mas potente na construção de saberes de valorização das mulheres e das crianças. 


\section{1 “ARRUMA UM IRMÃOZINHO PARA ELE”: O QUE NÃO APARECE, MAS SE FAZ PRESENTE NO CURRÍCULO}

Em encontro formativo que promoveu debate sobre o livro Educar meninos $e$ meninas: relações de gênero na escola (2006), escrito pela professora brasileira Daniela Auad, foi apontado um elemento que mereceu ser analisado em separado nesse subitem: a importância do currículo da Educação Infantil na consolidação da maternagem. Essa discussão surge a partir de relato de uma participante e posteriores opiniões socializadas pelas demais, que apontaram para a dificuldade das participantes em descentralizar a responsabilidade da resolução de problemas das crianças do âmbito familiar.

Além de distanciar a creche da concretização da maternagem, isso também compromete os direitos das crianças, pois fica prejudicado o favorecimento de habilidades e capacidades que são pilares de trabalho da Educação Infantil, como mediar os conhecimentos e promover interações culturais e sociais diversas, conforme prescrito nas Diretrizes Nacionais Curriculares da Educação Infantil (BRASIL, 2009).

Destoa, também, do movimento político analisado pela professora brasileira Fabiana Canavieira, no artigo intitulado "Caos calmo": (in)constâncias no cenário da política de Educação Infantil brasileira, publicado no ano de 2012. Nesse texto, a autora traz apontamentos sobre a construção epistemológica e política da Educação Infantil no Brasil, numa crescente dos "novos paradigmas teórico-metodológicos que põem as crianças no centro de seu processo educativo" (CANAVIEIRA, 2012, p.1), compreendendo especialmente os dois governos do ex-presidente Luiz Inácio Lula da Silva, nos anos de 2003 a 2010.

Apesar das idas e vindas, avanços e retrocessos que denotaram a vulnerabilidade da área, Canavieira (2012) distingue, no período estudado, a maior movimentação em termos de processos de construção política coletiva, em que foram discutidas a implantação das Diretrizes Curriculares, a oferta de creches noturnas e nos finais de semana, o conhecimento do perfil de demanda, a continuidade dos programas da COEDI, como o Pro Infância, a avaliação de desenvolvimento das crianças, a invisibilidade dos bebês, dentre outros temas.

A Educação infantil teve ganhos políticos e epistemológicos na divulgação e solidificação de uma concepção de educação para pequena infância que destaca o papel das crianças como centro de seu educativo e a organização dos saberes e fazeres das instituições de educação infantil tendo como base as brincadeiras e interações. Dando destaque também, para a função sóciopolítica desta etapa da educação, além de contemplar a realidade de populações não urbanas (CANAVIEIRA, 2012, p.10). 
Realizado em 2019, dez anos depois da formulação das Diretrizes Curriculares Nacionais da Educação Infantil, e nove anos após significativos diálogos favorecidos por governo de esquerda, olhar político que favoreceu as discussões sobre as crianças pequenas, no presente encontro formativo, foi relatada uma curiosa situação, sobre uma criança que tinha dificuldades em dividir seus pertences. Em diálogo com o pai da criança, a participante Larissa orientou que o casal tivesse outro filho, para que essa nova realidade envolvesse a criança. Perguntada sobre o ocorrido, a participante informa que:

O problema é que o menino está crescendo é difícil para ele, é igual eu perguntei pra ele esse negócio do irmão, o $\mathrm{XXXX}^{83}$ queria muito um irmãozinho para ele, mas tudo é dele. Então, nós ficamos perguntando para o pai dele, eu comentei com a mãe dele também, ela é uma gracinha, super educada, ela falou: "- Não, não eu ainda não posso, não." Que não sei o que. Eu falei não, é porque ele tem essa dificuldade, tudo é dele "- Tudo é meu, quero tudo.", e ele ainda fala assim "- É de menina, é de menino.", coisa que ele está aprendendo ele não aceita nada rosa, isso é de menina, isso é de menino. Se viesse um outro ele ia começar a entender, ia começar a dividir, essas coisas.

Conforme o relato, aparentemente não houve menção da participante em fomentar, por atividades ou práticas realizadas na creche, as habilidades sociais daquela criança, para que ela superasse a dificuldade de emprestar seus objetos. A solução encontrada nessa ocasião foi focar na ação da família, o que incorre em um distanciamento da creche.

Desse ponto, é interessante pensar nas variadas formas de omissão que se reverberam por distintos mecanismos públicos, como a ausência de políticas para a infância no município de Juiz de Fora (MG), apurado por Ramos (2016), os discursos políticos que responsabilizam unicamente a escola e a Educação como combatentes das desigualdades sociais (ZEICHNER, 2008) e as expectativas sociais que desconsideram os direitos de cidadania das mulheres por conta da maternidade e dos cuidados com as crianças.

Aqui tanto o direito da criança a uma educação, quanto o direito da mulher são desmerecidos pela instituição, que deveria contribuir de outra maneira, o que nos coloca uma discussão sobre o currículo e as influências das relações de poder, no que tange aos distintos interesses sociais e políticos, focalizados na educação dos indivíduos. Analisando as construções dos currículos no livro Ideologia e currículo (1982), o professor Michael Apple compreende que as relações e práticas sociais, e seus valores, estão predominantemente

\footnotetext{
${ }^{83}$ Omissão por menção ao nome da criança.
} 
arraigadas em nossas mentes, o que representa distintos compromissos políticos e pessoais na tarefa de educar. Logo, educar é um ato político, distante de neutralidade, pois se reflete, na escola, as dimensões sociais hegemônicas. Apple (1982) é taxativo em dizer que os currículos, enquanto artefatos educacionais, são a materialização desse reflexo, pois é por eles que...

[...] atribuem-se racionalmente significados às coisas, por meio de seus vínculos e ligações complexas com a forma como uma sociedade é organizada e controlada. As próprias relações são as características definidoras. Desse modo, para compreender, digamos, as noções de ciência e de indivíduo, como são particularmente empregadas em educação, precisamos vê-las como categorias basicamente ideológicas e econômicas, essenciais tanto à produção de agentes para ocupar os papéis econômicos existentes, quanto à produção de tendências e significados, nesses agentes, que "farão" com que aceitem esses papeis alienantes sem muito questionamento. Passam a ser assim aspectos da hegemonia. (APPLE, 1982, p.22).

Partindo desse pressuposto, Apple (1982, p.26) propõe que, enquanto professoras e professores, façamos um exame crítico acerca de "um campo de ação mais amplo de conflito econômico, ideológico e social", para que efetivamente acessemos um discernimento e uma compreensão da atividade de homens e mulheres, em dado momento histórico, nas reais condições sociais que nos cercam. $\mathrm{O}$ autor sustenta que uma reflexão consistente acerca dessas condições, e suas manifestações nos currículos escolares, só podem ser entendidas de modo satisfatório por meio de uma abordagem relacional dos conceitos de hegemonia, tradição seletiva e ideologia, em um movimento de "situar" as técnicas educacionais em um contexto mais amplo.

Tal movimento permite um "mergulho" na compreensão do papel das escolas na reprodução cultural e das estruturas de classe das sociedades industriais, em que cumprem uma função ideológica por "prepararem o conhecimento" a ser socializado (APLLE, 2012). Desta forma, é importante ressaltar que a contradição expressa no comentário de Larissa, em se abster de fomentar uma capacidade de socialização da criança, corresponde exatamente ao não cumprimento de uma função primordial da Educação Infantil, a de fomentar o conhecimento de si e das outras pessoas na creche, enquanto coletividade.

Essa "falta" de conhecimento, além de um desrespeito ao direito da criança, se desdobra em outras relações em termos de poder, pois isso implica em negação de acesso a "determinados tipos de poder político e econômico na sociedade" (APPLE, 2012, p.29). Isso 
nos instiga a pensar sobre o conhecimento enquanto poder, e o quanto isso se relaciona à manutenção de uma ausência de poder em certos grupos sociais, como a negação do direito da criança em ser mobilizada em aprendizado de convívio comunitário, mesmo ela sendo reconhecida como cidadã e pertencente ao grupo que é prioritário.

Reconhecemos tal relato como um movimento de conservação como uma manutenção do sistema patriarcal, que, conforme as análises de Saffioti (2011), coloca a dominação masculina, também, em termos reprodutivos, em induzir a mulher a ter e controlar o número de filhos/as, "embora elementos femininos possam intermediar e mesmo implementar estes projetos" (SAFFIOTI, 2011, p.106).

Nos parece interessante pontuar sobre o currículo manifesto, ou real, e o currículo oculto. A família e a sociedade são debates presentes nos currículos da Educação Infantil brasileira, no entanto, a hierarquia familiar tradicional - na perspectiva de gênero - é reforçada, uma vez que foi direcionada ao pai a orientação de ter outro filho, e situada na esfera familiar a resolução para o conflito da criança não emprestar seus brinquedos. Isso é consenso forjado em estatuto social conservador, configurando uma resistência a uma concepção sociointeracionista pela educação, como defende a presente tese, em concordância com os pressupostos de Mollo-Bouvier (2005), e um desafio à consolidação da maternagem na creche, de modo profissionalizado.

Ao lado disso, a participante, ao associar tal relato ao tema da pesquisa, nos traz questionamentos sobre o currículo oculto, pelas tendências e valores presentes nas rotinas e cotidianos institucionais, em aproximação com as ponderações de Apple (1982) a esse respeito. O distanciamento da creche do "conteúdo" desse relato sugere também a existência de uma lacuna reflexiva sobre o "conteúdo" do currículo real da Educação Infantil por parte das educadoras, que é (ou deveria ser) um compromisso desse nível de ensino com a promoção de aptidões para a formação da criança e o compartilhamento da Educação, ou seja, a maternagem.

Outro ponto passível de análise é como uma postura antidemocrática é insensível à promoção de justiça social via Educação, pois a produção intelectual (ou a falta dela) é determinante ao caráter de um controle social que favorece os processos de dominação e vulnerabilização das mulheres e das crianças, o que não se afina nem os Direitos Humanos, nem com a democracia, na perspectiva agonística de Mouffe (2003), com a qual nos identificamos. 
A creche nasceu como bandeira de luta das mulheres, com o primeiro propósito de atender as necessidades laborais, e foi adquirindo outros contornos a partir das preocupações das mulheres com a qualidade do atendimento, respaldadas também pelos avanços científicos que passaram a privilegiar os aspectos relativos às infâncias, ao lado das discussões políticas e sociais que reconheceram a criança cidadã.

A questão dos cuidados com as crianças seguem associadas às mulheres, ainda que a creche se reconheça formalmente como parceira nessa tarefa. Ao lado disso, as participantes dão a entender que essa parceria tem sido somente prática, na atenção com os cuidados e necessidades das crianças, e na forma de preocupações com as situações de vulnerabilidade social. Ainda que sensíveis às questões individuais, observa-se um distanciamento das participantes enquanto mulheres, na maneira apressada em responsabilizar ou classificar negativamente as condutas das mulheres-mães das creches, num claro movimento de diferenciação.

É também nítido o movimento das disputas de poder - em perspectiva retrógrada que perpassam os currículos da creche e da Educação como um todo - que reduzem os debates sobre os direitos ao respeito. Evidentemente, as ações e práticas precisam ser respeitosas, mas se observou, pelas contribuições das participantes, que os olhares da creche seguem estigmatizando os públicos que atendem, pois a raiz de todos os problemas e a solução destes - segundo elas - estariam na socialização primária, ou seja, na família. Isso se dá como efeito dos ataques que as escolas e instituições de ensino vem sofrendo como espaços formadores, enquanto espaços de questionamento e pensamento crítico, principalmente, em relação aos grupos historicamente marginalizados, às desigualdades sociais e à lógica desumanizadora do liberalismo enquanto sistema econômico.

\section{2 "MUITO DIFÍCIL SER MULHER": REFLEXÕES SOBRE GÊNERO, VIOLÊNCIA E CONCEPÇÃO}

Foram apresentados às participantes do encontro formativos dois vídeos, que contrastaram as históricas discussões políticas sobre os direitos das mulheres e o acesso as creches pelas mães trabalhadoras. As participantes informam que não compreenderam o conteúdo do primeiro vídeo, "Movimento feminista e a luta das mulheres - Entrevista com Amelinha Teles". O segundo vídeo, intitulado "Lugar de criança: A sociedade civil e a luta pelo direito à creche" foi melhor acessado pela identificação das participantes com as 
mulheres depoentes, como mulheres e mães trabalhadoras. Muitas questões como o combate às desigualdades, representatividade política e violências contra a mulher foram socializadas nesse momento formativo.

Ao debaterem sobre a notoriedade da Lei Maria da Penha, a participante Sueli disse "Tá, mas deixa eu falar. A lei Maria da Penha existe, mas é muito complicado, porque, muitas vezes, a mulher procura o homem de novo, tem a medida protetiva, mas o cara vai lá e mata.". Sobre isso, Elô relata que "- Mas eu já vi um caso que quando a mulher reage e bate no homem, assim, a mulher bateu no cara e ele não fez nada, ficou com vergonha. E, aí, falaram "- A mulher tá batendo, ela bate também"”. Outro questionamento sobre as violências contra as mulheres é a não compreensão das participantes de a mulher agredida continuar seu relacionamento, ou não denunciar a violência que sofre. As informações colocadas pelas entrevistadas se aproximam com os olhares equivocados e distorcidos sobre a mulher vítima de violência, recorrentemente culpabilizada e crucificada pelo meio social. A reprodução desse olhar exalta uma Prática não constituinte de Cidadania. Esse quadro pode ser analisado conforme a literatura feminista acessada na presente tese, no que se refere à violência contra as mulheres. A violência existe como um sintoma da ordem social e política, que é ressignificada a partir da categoria gênero (SCOTT, 1997).

Saffioti (2011) situou o fenômeno do patriarcado como importante fator estruturante em nossa sociedade forjador das engrenagens das desigualdades entre mulheres e homens. Analisando o par igualdade-desigualdade sob a ótica da violência, haja vista a igualdade legal prescrita na Constituição Brasileira de 1988, Saffioti (2001) pondera que é a partir das práticas cotidianas que a igualdade se transforma em desigualdade. Uma vez que as expectativas negativas à mulher - falta de autonomia por cerceamento dos homens, peso da responsabilidade com as crianças, dupla jornada de trabalho - contribuem a essas se enxergarem como inferiores, o que torna ainda mais urgente "a necessidade de tornar ainda mais visíveis as várias modalidades de violências praticadas contra as mulheres, em especial a violência doméstica"(SAFFIOTI, 2011, p.44).

Logo, a questão da violência, especialmente a ótica sobre as atitudes das vítimas, abordada pelas participantes, é uma das manifestações de interdição e sujeição da mulher pelos machismos, por meio das socializações das expectativas tradicionais pautadas pelo gênero, conforme já reiterado. As dinâmicas das socializações que envolvem o gênero continuaram a compor o debate das participantes. Larissa entende que a instância de maior 
peso nas socializações de gênero é a família. Ela se baseia em fato presenciado na creche, em relato transcrito a seguir.

Ela tem três anos, a menininha, eu dou aula para a turma de três anos. Essa menina veio outro dia para a creche de short curto muito curto [...]. Eu não concordo de pôr short curtinho em criança [...] não era curto só tava dando para ver a polpa da bunda [...]. Aí, eu não falei nada, a própria mãe que falou: "- Olha, tia, olha o shortinho de periguete que ela gosta. Pergunta para ela esse shortinho é de quê?" E a menina falou "- Periguete". A própria criança falou [...], mas isso é porque ela escuta falar em casa.

O relato de Larissa gerou muita comoção entre as participantes, em matéria de concordância com o posicionamento do diagnóstico da postura da família em construção de gênero emitida à criança, em viés pejorativo. No entanto, a participante Raquel apresenta outros direcionamentos possíveis, a partir da instância da família.

“- Eu acho assim, tudo isso acontece, mas eu acho que pode ser diferente eu, por exemplo, sempre falei com meu filho, hoje ele tem 19 anos. Ele não pode fazer a filha dos outros de boba ... Quando ele começou a namorar, eu falava muito isso com ele, que ele tem que respeitar e respeitar o sentimento dos outros ... Aí, ele começou a namorar a menina uma menina boa, gente boa mesmo, de 17 anos na época e tava tudo bem... E, aí, um dia, ele falou comigo vou terminar... Ele disse que não estava legal que gostava dela, mas que não gostava tanto e eu perguntei: "- Meu filho, mas aconteceu alguma coisa porque agora você está vindo com isso? Ela é tão legal". Aí, ele virou para mim e disse: "- Porque você me ensinou a não brincar com as pessoas". Aí, eu calei a boca, porque ele estava fazendo o que eu ensinei. Então, ele é homem, mas não agiu de forma... sabe?! Ele foi honesto e terminou... Então, ela ficou muito triste, eu também, não queria que ele terminasse. Como eu disse eu gostava dela, mas depois eu pensei que foi o melhor mesmo. Melhor que ele ficar fazendo ela de idiota, traindo.

É fato de que a família seja instância de referência importante na Educação das crianças. Mas existem outras, como as escolas, as mídias, as igrejas, os discursos, a política, os símbolos e a justiça, como nos lembra Louro (1997). Contudo, ao compararmos os comentários de Larissa e Raquel, observamos que a materialização de posturas que educam para a socialização do gênero assume efeitos distintos. Os distintos enfoques relatados - o reforço de estereótipo social, no primeiro relato, e a reconstrução da sensibilidade, no segundo - foram os meios que proporcionaram às pessoas procederem a uma $\underline{\mathbf{e}}$ outra interação com as expectativas sociais que tocam o gênero. A despeito de as duas situações mencionadas terem ocorrido pela via da participação da família, é digno de nota que os atos observados se deram através de mecanismo de educação, e ficou explícito que tanto o movimento de conservação 
das relações de gênero tradicionais, quanto o de reconstrução das mesmas relações podem ocorrer. Entendemos que tal ambiguidade são os processos de mudança e de conservação a que as práticas sociais em geral estão sujeitas, o que indica que há uma movimentação ocorrendo no que diz respeito às construções sociais que balizam os processos de educação, mesmo que estas estejam em oposição de suas forças, em disputa de poder.

O tema da família continuou sendo discutido pelas participantes, que comentaram sobre as questões trabalhistas, o que levou a comentários sobre formação da família, reprodução, aborto e métodos contraceptivos. Alvoroçadas, as participantes perguntaram a opinião da pesquisadora sobre a questão do aborto, e a partir dela foram se manifestando. Seguem alguns trechos dessa acalorada discussão: “- Eu não sei” (Participante Mariana); “Eu sou contra” (Participante Raquel); “- Totalmente contra” (áudio com muitos ruídos - sem identificação); “- Eu acho que a mulher tem que fazer em caso de estupro. Fora isso eu acho que a mulher tem que tomar remédio" (Participante Elô); “- Mas e o homem? Mulher não faz filho sozinha” (Participante Carmen); “- Se o homem não liga” (Participante Gabriela); “- A mulher vai e pega e toma" (Participante Sueli); “- Simples" (áudio com ruído-sem identificação). Gabriela pede a palavra e expõe seu posicionamento, ao que Dani se manifesta a seguir:

“- Sou totalmente contra, a não ser em casos de estupro ou em casos, assim, que você contou, ou de risco de vida, assim, alto. Eu sou contra, porque eu penso que isso pode ser evitado, assim, numa situação normal. Eu entendo que sim, tem todas essas situações de dificuldade, mas eu também sei de casos igual a uma vizinha minha, que engravidou e comprou remédio, $o$ $\mathrm{XXXXXXX}^{84}$. Ela usou o remédio, fez o aborto e, dois meses depois, estava grávida de novo. Fez o aborto de novo e depois não sei, porque perdi $o$ contato. Eu fico pensando se o aborto fosse permitido que essa minha vizinha ia ficar fazendo abortos, assim... todo mundo ia engravidar e não pensar em nada. Por isso tudo eu sou a favor da laqueadura". (Participante Gabriela).

“- Então, o que ela está falando é o que eu entendo sobre os feminismos, mesmo eu não me considerando uma feminista... Porque eu não... Então, o que está em discussão é o direito ao corpo, que a mulher não tem. Então, a mulher não tem direito de escolha. Não é sobre fazer o aborto necessariamente, é sobre a gente decidir o que vai fazer com o nosso corpo". (Participante Dani).

Novamente, os debates são marcados pela ambiguidade, dessa vez sobre os direitos das mulheres. O estudo da antropóloga brasileira Andrea Moraes Alves, intitulado "Memória

\footnotetext{
${ }^{84}$ Omissão por menção a nome de medicamento.
} 
da esterilização feminina: um estudo geracional" (2007) aborda o tema da regulação da fecundidade feminina. Para além da medicalização, a laqueadura foi difundida no Brasil como prática a fim de evitar filhos nas décadas de 1970 e 1980, e tratada de forma ambígua pela Ditadura Militar. Coexistiam, na citada época, posturas pró-natalistas, com claras preocupações sobre a questão de ocupação de território, ao lado de preocupações com a utilização de métodos contraceptivos, que tinham o intuito de reduzir a população, em combate à pobreza e à violência urbana. Ao lado disso, fervilhava o movimento feminista em todo o mundo, inclusive no Brasil, reivindicando o poder sobre o corpo. Nos anos 1990, surge a Lei de Planejamento Familiar, de número 9.263 de 1996, a partir do reconhecimento do planejamento familiar como direito social pela Constituição Federal de 1988.

A citada lei regulamenta a laqueadura feminina (e a vasectomia, no caso dos homens) enquanto procedimento a ser oferecido pelo sistema público de saúde, “[...] no quadro de uma política mais ampla de educação sexual e planejamento familiar" (ALVES, 2007, p.189). No entanto, Alves (2007, p.189), baseada em literatura produzida sobre a esterilização feminina, identifica que o tema comporta três dimensões: "a relativização da ideia de autonomia feminina no campo reprodutivo; a relação hierárquica e moralizante entre médicos e pacientes; e a identificação, no país, de uma 'cultura da esterilização feminina"”.

Alves (2007, p. 189) aponta que a esterilização feminina, além da modernização das políticas públicas da área da saúde, contou com outros fatores de influência, "como as políticas de crédito ao consumidor, de telecomunicações, de previdência e de atenção à saúde" o que gerou "impactos não previstos sobre a regulação da fecundidade no Brasil". Ao realizar pesquisa qualitativa com mulheres sobre as representações da esterilização em suas vidas, Alves acessou referências importantes no nexo por trás da decisão pelo procedimento da laqueadura. A autora identificou um movimento de "maternidade responsável", no qual se fizeram presentes razões como a preocupação com o número de filhos, a rede de troca de informações com a família, a estética do corpo, indicações médicas acerca de problemas de saúde, entre outras. No entanto, o aspecto mais recorrente foi a relação com os parceiros.

A razão maior pela qual as mulheres se esterilizam se relaciona com a presença ou ausência do apoio masculino, seguido da falta de responsabilidade dos homens para com os métodos contraceptivos, e de preocupações com os efeitos estéticos que muitas gestações impõem ao corpo, percebidos pelas críticas feitas pelos homens, como também debate Auad (2003). Muitas mulheres, de acordo com Alves (2007), temem a humilhação pelos maridos nesse sentido, seja ela verbal, ou materializada, na forma de casos extraconjugais. 
Deste modo, e ainda que se somem outras preocupações relacionadas à reprodução, e também ao trabalho, as mulheres buscam a laqueadura não inteiramente de forma autônoma, já que decidem pelo procedimento condicionadas ao relacionamento com o homem. O direito de decidir pelo próprio corpo ainda não é pleno, reivindicação feminista relembrada pela participante Dani, mesmo porque o procedimento depende de autorização a ser assinada pelo marido. Destacamos que essa foi a única reflexão em perspectiva feminista observada nos encontros formativos.

Ao lado das questões "pessoais" envolvidas na ocasião da laqueadura, Alves (2007) analisa que o olhar dos programas de governo voltados às mulheres, e os métodos contraceptivos se direcionam as mulheres de baixa renda e baixa escolarização. Comprovando a assertiva de Alves (2007), no ano de 2018, realizou-se uma campanha, promovida pela prefeitura do município de Quaraí, no estado do Rio Grande do Sul, que deixou clara a visão sanitária sobre a constituição de famílias por parte das pessoas pobres.

Figura 5. 1: Campanha de planejamento familiar Prefeitura de Quaraí.

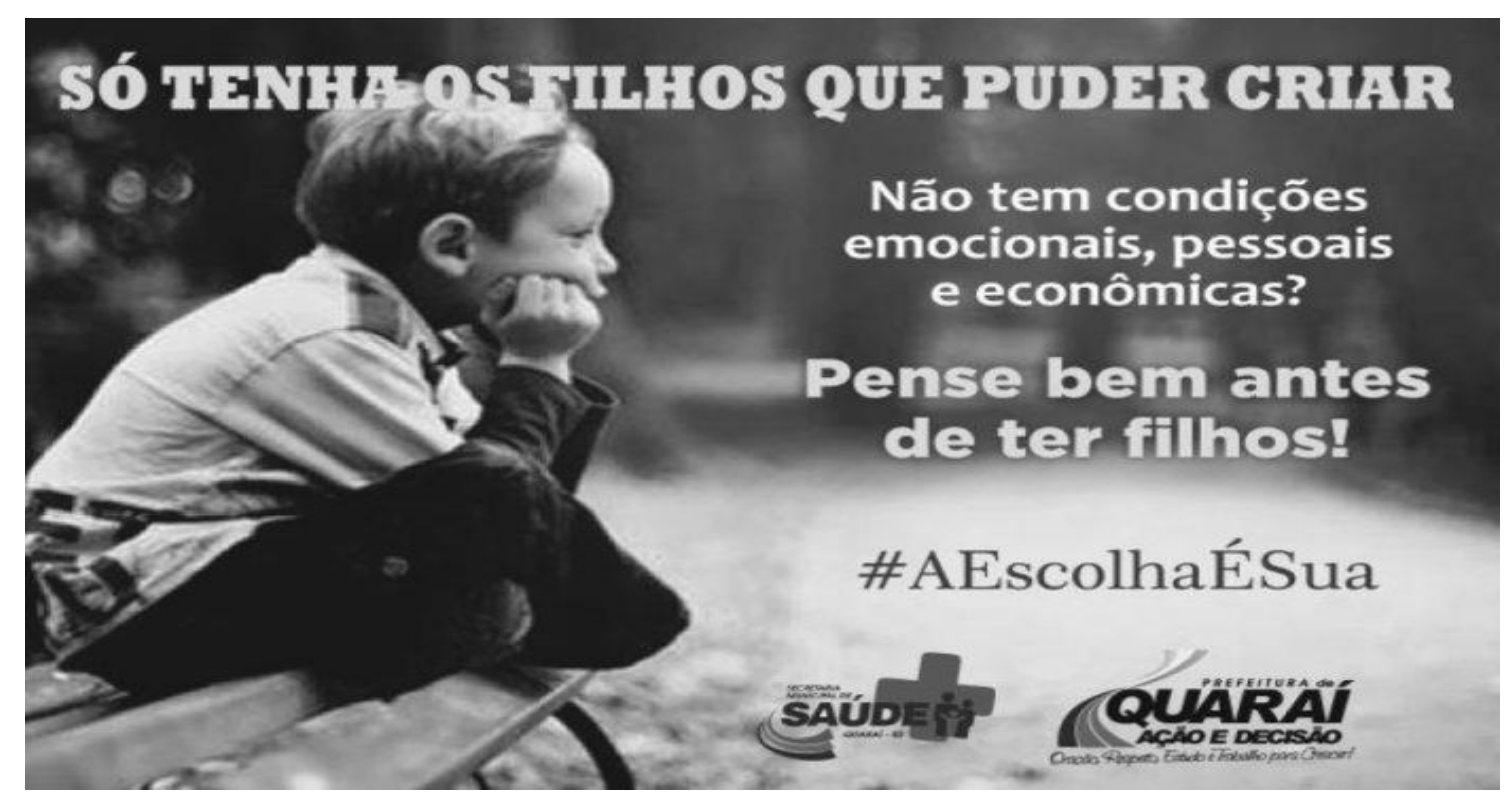

Fonte: Créditos da Imagem- facebook.com

A campanha condicionou o planejamento familiar às possibilidades financeiras, emocionais e pessoais, reforçando o olhar negativo à população pobre, "aferindo" os critérios para constituição de uma família, em flagrante desrespeito a um direito social garantido por lei. Os mecanismos de exclusão e preconceito se fazem presentes e repaginados, pois a justificativa da campanha se pautou na necessidade "de despertar na população 
conscientização, reflexão e responsabilidade ${ }^{, 85}$, o que faz perdurar no imaginário social que a "cultura de esterilização", identificada por Alves (2007) e rememorada no comentário de Gabriela, seja admitida como a melhor "solução" de contracepção.

Além de a responsabilidade do planejamento familiar recair historicamente com maior ênfase na mulher, perdura a estigmatização das famílias pobres, que são tidas como suspeitas em prover uma família, ao contrário das famílias ricas, que manejam distintamente as decisões de constituir (ou não) família. Como se não bastassem os problemas de acesso aos métodos e a precariedade dos serviços do sistema de segurança pública, há outra triste violação dos direitos: a esterilização em massa e involuntária de mulheres. Realizou-se, nos anos 1990, uma Comissão Parlamentar Mista de Inquérito destinada a investigar essa realidade, por meio de denúncias sobre essa prática. À época, o IBGE apurou que $33 \%$ das mulheres casadas ou unidas, de faixa etária entre 16 e 54 anos utilizavam a esterilização. De acordo com o Relatório, se considerada a idade fértil das mulheres, esse alarmante percentual sobe para $44 \%$, cujo entendimento é o de que a esterilização é o medo mais comum de contracepção.

Alves (2007) relata que o pressuposto de que não há leis que estabeleçam uma legalidade sobre a interrupção da função reprodutora, a suspeita da CPI recai sobre um imbróglio que envolve a precarização de informação e a falta de critério na recomendação médica em se indicar a laqueadura, preterindo-se outros métodos. A mesma autora afirma que essa prática possui caráter genocida e racista, pois desde o século XIX, com a descoberta da penicilina, a laqueadura fora utilizada, sob o olhar da eugenia.

A higienização da população brasileira infelizmente não é ideário desconhecido, principalmente às pessoas negras e indígenas. Em publicação recente sobre o tema, o Jornal Intercept reproduz o decreto-lei de número 7.967 de 1934 do governo Getúlio Vargas, que expressa: "Atender-se-á, na admissão dos imigrantes, à necessidade de preservar e desenvolver, na composição étnica da população, as características mais convenientes da sua ascendência europeia (...)" (Art. $2^{\circ}$ ). O citado Jornal aponta que a CPI concluiu que eram verídicos os altos índices de esterilização e apurou-se que programas de controle e planejamento familiar financiados com capital internacional eram entidades que promoviam a esterilização de milhares de mulheres de maneira involuntária, em sua maioria, mulheres negras. Em decorrência do ocorrido, o então presidente Fernando Henrique Cardoso, ao

\footnotetext{
${ }^{85}$ Fonte: https://notisul.com.br/geral/giro-pelo-brasil-campanha-sobre-planejamento-familiar-gerapolemica/. Acesso em 23/05/2020.
} 
sancionar a Lei de Planejamento Familiar, expressou a obrigatoriedade de manifestação pela esterilização por escrito, após discussão sobre os riscos do procedimento ${ }^{86}$.

Mesmo existindo a citada lei, a precariedade por parte do Estado em promover políticas públicas abrangentes e mais específicas, contribui a ações enviesadas com relação ao direito social de planejamento familiar, assim como em outros tempos, foi o mote propulsor do assistencialismo, em ações clientelistas e filantrópicas (ALVES, 2016). A essa situação, se soma o que a cientista social brasileira Marlene Tamanini (2016) reconhece como a ação da intervenção discursiva e simbólica que, por meio de controle, ainda que não exercido de forma objetiva, garante a aplicação da norma. Trata-se de dinâmica que veicula uma idealização, assim como a referente à maternidade, do planejamento familiar, que "se encontra preconizada nas perspectivas das ações em saúde, ou nas legislações e normativas, políticas e em suas institucionalizações" (TAMANINI, 2016, p. 827).

Novamente, uma condição biológica é utilizada no meio social para regular um direito social garantido por lei, em uma sutil e não declarada ação de grupos socialmente dominantes, intervindo na organização familiar. Conforme os dados disponibilizados por Alves (2007) e pelo Jornal Intercept, é possível estabelecer uma análise relacional, pela interseccionalidade das categorias gênero, raça e classe, quanto ao público-alvo de campanhas e decretos de governo e os serviços de saúde.

A diferenciação das classes sociais, apontada por Alves (2007), pela matéria do Jornal Intercept, e pela análise de Tamanini (2016), foi dimensão tocada pelo texto das, também, antropólogas Roseli Maria Porto e Cassia Helena Dantas Souza (2015), intitulado "Ter feito aborto não me tira o direito de ser mãe": dilemas relativos à interrupção de gravidez e o exercício da maternidade nos discursos de mulheres em uma capital nordestina. Tal texto divulgou resultados de pesquisa sobre os itinerários abortivos de mulheres moradoras de uma capital de estado da região Nordeste. Em pesquisa que contou com diversos perfis de mulheres que realizaram abortos provocados, as autoras apuraram que a situação econômica e as redes de contatos foram preponderantemente decisivas nos percursos vivenciados pelas mulheres.

A situação econômica, conforme Porto e Souza (2015) interfere diretamente no planejamento e na aquisição de insumos e medicamentos necessários ao procedimento. As autoras relatam que, ainda que o aborto represente um processo angustiante para todas as mulheres que participaram da pesquisa, ter ou não como arcar com os meios necessários ao

\footnotetext{
${ }^{86}$ Fonte: https://theintercept.com/2018/07/18/laqueaduras-esterilizacao-forcada-mulheres/. Acesso em 23/04/2020.
} 
aborto implicam em vivências mais ou menos constrangedoras, em termos de exposição e condenação pública, seja da mulher que quer abortar, ou da mulher que abortou, que chega aos serviços hospitalares.

Outro ponto revelador que o texto de Souza e Porto (2015) nos traz são sobre as redes de contatos, que apontam uma intensa participação e colaboração dos homens nos itinerários abortivos. De acordo com as autoras, eles são os principais fornecedores de meios para que as mulheres realizem o aborto, inclusive orientando o procedimento. Logo, observamos que se trata de mais uma maneira em que a agência masculina detém o poder de atuar na esfera reprodutiva. Em atuação colaborativa ao aborto, persiste a ação instrumentalizadora do homem, como pontua a cientista social e feminista Lucila Scavone (2001), ainda que a ação expressiva da maternidade caiba à mulher, a dominação segue se projetando, mesmo que a decisão seja de a mulher não seguir com a gravidez.

As preocupações com a interrupção da gestação parecem se relacionar, assim como exposto no capítulo 1 da tese, com a visão em que a valorização das novas gerações surge atrelada à formação dos Estados, vistas como mão de obra de reserva. Tal lógica, que toca a disponibilização de mão de obra, e sua venda no mercado de trabalho denota a força das pressões econômicas, que atuam na valorização, e também desvalorização, da situação da mulher e da criança no sistema capitalista. Nas palavras de Saffioti (2011, p.126):

[...] o capitalismo também mercantilizou todas as relações sociais, nelas incluídas as chamadas específicas de gênero, linguagem aqui considerada inadequada. Da mesma forma, a raça/etnia, com tudo que implica em termos de discriminação e, por conseguinte, estrutura de poder, imprimiu sua marca no corpo social por inteiro. A análise das relações de gênero não pode, assim, prescindir, de um lado, da análise das demais, e, de outro, da recomposição da totalidade de acordo com a posição que, nesta nova realidade, ocupam as três contradições sociais básicas.

Isso corresponde a uma opressão sexista, presente nas discussões sobre a legalização do aborto no Brasil, e que nega a autonomia da mulher, como já o disse Alves (2007), em mecanismo que reforça a autoridade do homem na organização social. Reconhecemos que tal ação é permeada por um ensejo pedagógico, pois a negação desse debate adquire contornos de produção de controle social, consistindo em uma dominação. Outra contradição da mercantilização das relações sociais é que a produção da desumanização que o capitalismo destoa completamente de um contexto legal de direitos iguais a todas as pessoas. 
É digna de nota a contradição expressa nas posturas dos homens com relação a esse tema. Em recente pesquisa divulgada no mês de janeiro do ano de $2021^{87}$, $79 \%$ da população brasileira é contrária ao aborto. Desse percentual, 82,6\% são homens. A linha de frente da formação de frentes parlamentares contrárias ao aborto, inclusive nas situações em que ele é permitido por $1 \mathrm{e}^{88}$ é, em sua maioria, compostas por homens, em "defesa da vida". Esse grande "apelo", no entanto, é utilizado para mascarar a manipulação e uma grande parcela de oportunismo na relação dos homens com a pauta do aborto.

Como demonstram Souza e Porto (2015), os homens estão presentes nas redes de acesso ao aborto, obtendo renda com isso. Corroborando as citadas autoras, o doutor Olímpio Barbosa Moraes Filho, médico responsável pelo aborto legal realizado recentemente em uma menina de 10 anos, oriunda do estado do Espírito Santo, deu declarações ainda mais contundentes sobre a realidade brasileira dos abortamentos à Comissão de Direitos Humanos e Legislação Participativa. Infelizmente, o Dr. Olímpio Barbosa é testemunha da uma triste realidade das mulheres pobres. Elas não contam com o direito ao aborto, ao mesmo tempo, em que ele não é criminalizado quando realizado por mulheres ricas, em clínicas e consultórios que dispõem das medidas profiláticas a um abortamento seguro, realizados por médicos, homens, de modo ilegal, por meio de pagamentos por esse serviço.

É nessa realidade em que nos baseamos para dizer sobre o oportunismo dos homens, que seguem seus próprios interesses à revelia das mulheres, por conveniência, pois como também descortinou o Dr. Olímpio Barbosa, o aborto não é mal visto pelos parlamentares quando as mulheres grávidas em questão são as mulheres de suas famílias que, ao receber toda a assistência, não morrem. Menos ainda, quando as mulheres que abortam "são as suas amantes" $" 89$. Desse modo, os homens fecham os olhos inclusive, ao funcionamento de estabelecimentos em que médicos homens realizam abortos ilegais, os quais se beneficiam economicamente às custas desse problema.

Outra perversidade desse oportunismo masculino em relação à questão do aborto é a contradição relativa à figura da criança. No Brasil, há mais de 5,5 milhões de crianças sem o reconhecimento do pai em seus registros de nascimento, conforme divulgação do Censo

\footnotetext{
${ }^{87}$ Fonte: https://www.poder360.com.br/pesquisas/8-a-cada-10-brasileiros-sao-contra-a-legalizacao-doaborto-mostra-pesquisa/. Acesso em 05/03/2021.

${ }^{88}$ Fonte: brasil.elpais.com/brasil/2020-01-17/lobby-antiaborto-se-espalha-pelos-parlamentosestaduais-brasileiros.html. Acesso em 08/03/2021.

${ }^{89}$ Fonte: https://www.youtube.com/watch?v=pDcuUT4TJ7c. Acesso em 20/07/2020.
} 
Escolar de $2013^{90}$. Outras formas significativas de abandono parental são o abandono material e o abandono afetivo, que tem sido reconhecido pela justiça brasileira como um não cumprimento de responsabilidade, sujeito a pagamento de indenização as/os filhas/os por danos morais. Há casos em que é manifestado o desejo de retirada do nome do pai da certidão de nascimento, matéria jurídica já aplicada na justiça, apoiada em jurisprudência ${ }^{91}$.

Mães solo também têm sofrido grandes impactos, principalmente, em razão da pandemia do Covid 19. As mulheres responsáveis por suas famílias perfazem um total mais de 11 milhões, sendo que $61 \%$ são mulheres negras, $28 \%$ brancas e $11 \%$ são de outras etnias. Com relação à classe social, a Síntese de Indicadores Sociais do IBGE revela que as mulheres negras e pardas correspondem a $24 \%$ do extrato da população mais pobre. Diante disso, as mães solo, se tornam mais vulneráveis a contrair a doença, já que precisam obter renda para sustentar suas famílias. Nessas condições, na impossibilidade de se manterem em isolamento social, as crianças correm sérios riscos de se verem desamparadas.

Logo, é preciso repensar os direitos básicos das mulheres, em perspectiva interseccional, numa justa compreensão das relações estruturais presentes nessas visões, e em seus meandros de ação política, que reproduzem a dependência dos interesses masculinos, em detrimento de condições mínimas de dignidade a elas, e também às crianças.

Figura 5. 2: Representações na Entrada e no Refeitório da creche
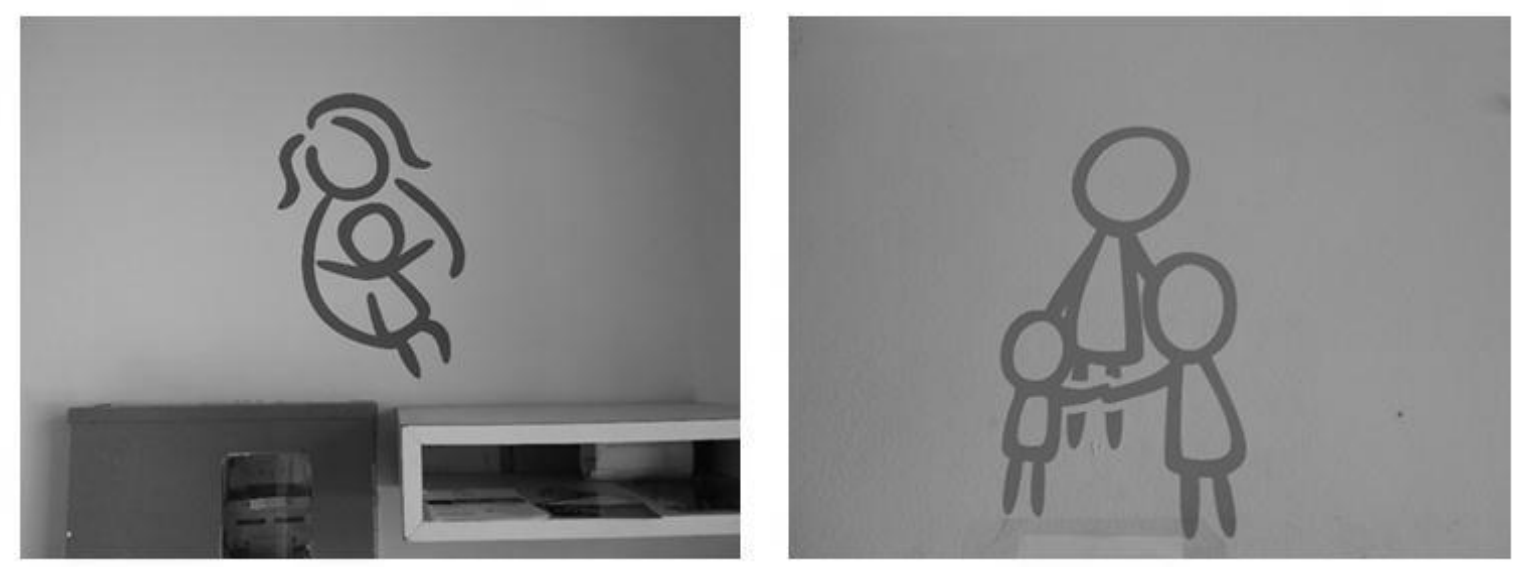

Fonte: Acervo de pesquisa da autora.

\footnotetext{
${ }^{90}$ Fonte:https://ibdfam.org.br/noticias/7024/Paternidade+respons\%C3\%A1vel: + mais + de $+5,5+$ milh $\% \mathrm{C}$ $3 \%$ B 5 es + de + crian $\% \mathrm{C} 3 \%$ A 7 as + brasileiras $+n \% C 3 \% A 3 o+t \% C 3 \% A A m+o+$ nome + do + pai + na + certid $\%$ $\mathrm{C} 3 \% \mathrm{~A} 3 \mathrm{o}+\mathrm{de}+$ nascimento. Acesso em 10/03/2021.

${ }^{91}$ Fonte:https://www.buscadordizerodireito.com.br/jurisprudencia/detalhes/41ae36ecb9b3eee609d05b9 $0 \mathrm{c} 14222 \mathrm{fb}$. Acesso em 10/03/2021.
} 
Logo, libertar as mulheres da maternidade obrigatória substituindo os modos de socialização domésticos pelos trabalhos especializados, atuaria na libertação da sociedade, também, uma vez que as mulheres se tornariam emancipadas, assim como os homens já o são!

A Educação dificilmente consegue reverter tal quadro, até porque é um empreendimento que conta com outras frentes políticas e institucionais, que contribuem na produção e disseminação dos significados das ordens sociais, como a esfera jurídica, ações políticas e a esfera conjugal, no que toca à mesclagem das diferenças entre o público e o privado (SAFFIOTI, 2011). No entanto, no que compete a essa seara - a Educação - o aborto e a violência contra a mulher são temas geradores de conflito, debate, opressão, tão presentes quanto não demarcados, que nos desafiam a transformar racionalmente tanto as relações interpessoais, quanto o olhar para com o conhecimento, ministrado nas creches e escolas de Educação Infantil.

\section{3 "EU NUNCA TINHA PARADO PARA PENSAR NISSO": NUANCES DO ANTIFEMINISMO E DO ANTINTELECTUALISMO}

Nesse encontro formativo, as participantes da pesquisa realizaram discussões baseadas nos elementos e análises do livro Educar meninas e meninos: relações de gênero na escola, de autoria de Daniela Auad (2006), no sentido de aprofundar o debate sobre os direitos das crianças e os direitos das mulheres tendo como locus a instituição creche. Esse material, para além da análise do cotidiano e das práticas escolares sob o enfoque do gênero, sugere caminhos para que uma Educação para a Democracia seja construída a partir da sala de aula, em utilização da desnaturalização das relações de gênero. Entendemos que essa obra possa ser ferramenta potente a um encontro formativo para em discutir o entendimento sobre os direitos das pessoas que acessam a creche. Uma resenha do livro foi disponibilizada à participantes, que após uma leitura conjunta, passaram a comentar os pontos debatidos nesse material, dentre os quais despontaram os fenômenos do antifeminismo - ou demonização do feminismo - e do antintelctualismo, a serem explanados no presente item.

O primeiro ponto levantado pelas participantes foi novamente a socialização de gênero. Ao lado da instância familiar como principal responsável nesse processo, e da identificação do pai como agente ativo, a participante Larissa informa sobre o reforço da socialização conservadora advindo das interações infantis: “- Gente, tem criança que fala 'que não, não pode chorar, porque homem não é mulher'”. Mas eu falo: “- Pode chorar sim!”. Essa 
é uma desconstrução possível das relações de gênero mais conservadoras, a partir da escola. Ao não polarizar as expressões das emoções das crianças, a partir de intervenção da participante, tal relato foi classificado como uma Prática constituinte de Cidadania. Mediante esse comentário, as demais participantes demonstraram concordar com a atitude de Larissa.

Sobre as análises de Auad (2006) que ponderam sobre as relações de poder que perpassam as interações de alunas e alunos com a professora, a participante Raquel se manifestou acerca desses arranjos, mais precisamente sobre as dinâmicas em que as crianças auxiliam em sala de aula:

“- Já aconteceu isso. Mas, por outro lado eu nunca tinha parado para pensar nisso, como isso tudo é feito pela menina o menino se sente desafiado sabe?! Aquela coisa. Uma coisa é autoridade da escola, outra coisa, outra a mulher, no caso a menina que é a colega dele que tem a mesma posição que ele estar com aquela posição, também, de estar lá, de cobrar, de ensinar, entendeu?! Porque acaba acontecendo um pouco, assim, né?!”.

Assim como no debate proposto por Auad (2006) são comuns, pelo olhar de Raquel, os arranjos escolares que permitem que alunas ajudem colegas em seus aprendizados em sala de aula. Raquel parece supor que a mediação dos processos de escolarização se associa à escola como grande agente em proporcionar aprendizados, e de que as relações das pessoas naquele espaço devem (ou deveriam ser) horizontais. Em outras palavras, a participante parece se referir ao entendimento de que todas pessoas na escola podem atuar ensinando e também aprendendo.

A formulação da autora, que versa sobre o significado de que muitas das práticas escolares, na perspectiva de gênero utiliza, dentre outros artifícios, de privilégio e/ou apagamento das ações de indivíduos, que deixam implícitos os sentimentos de superioridade/inferioridade (AUAD, 2006) causa estranhamento em Raquel, que nunca havia pensado sob esse prisma. Tal estranhamento se corrobora pelas pesquisas da própria Auad (2003; 2006), e de todas as autoras feministas que asseveram que a categoria gênero passa despercebida, pois naturalizada como costume, como podemos observar na resposta de Larissa ao comentário de Raquel:

“- Mas eu acho, assim, bem, bem, bem, bem... eu não acho que é humilhar, não... ele é muito quietinho, muito na dele até meio paradão, sabe?! E a XXX tava me contando que a mãe dele tem mania de limpeza, sabe?! Aí, ela tava me contando um dia eu comentei: '- Ele é paradão, como que é na casa dele?'. Aí, ela falou que a mãe sempre deixa ele na casa da avó, porque o negócio dela é limpar a casa, deixar a casa muito limpa, muito isso e aquilo, 
e o XXX não pode ver um pano na minha sala que ele tá limpando entendeu?! Aí, eu não sei se é por causa da idade, não sei isso, antigamente, acontecia, os meninos ver a mãe fazer será que eles reproduziam igual hoje? Porque, eu acho que não acontece com os meninos... Aí, de repente, isso fica na cabeça dele, assim: 'tem que limpar, se eu tô vendo o pano, vou limpar ali que tá sujo', porque as pessoas quando têm mania assim não gosta nem que você respira, né?!".

Larissa parece associar a atitude de aluno ao costume da família, o que é uma reconstrução de gênero possível, na qual o menino contribui, em maneira distinta às expectativas de gênero, para a organização da sala de aula. Sobre a principal linguagem das crianças, o brincar, pilar principal da Educação Infantil, o texto A Produção Científica sobre o brincar entre meninos e meninas na Educação infantil: rompendo fronteiras e construindo novas perspectivas para a diversidade (2013), escrito pelas professoras brasileiras Heliany Pereira dos Santos e Altina Abadia da Silva, nos dá interessantes pistas para pensar sobre a agência das crianças, perpassadas pelas relações de gênero, e a construção de suas ações futuras nas relações sociais.

[...] a importância deste brincar está relacionado à possibilidade de compreender o pensamento e a linguagem de si e também do/a outro/a, pois quem brinca é capaz de improvisar elementos de seu ambiente, buscando novas significações (SANTOS; SILVA, 2013, p. 6).

Ao ponderar que a exploração advinda do brincar, fica subentendido que, além de momento de descontração, é uma ação na qual a criança goza de uma liberdade de criação, ao experenciar os códigos sociais, artefatos e objetos de seu entorno. Partindo desse pressuposto, o comentário de Larissa nos instiga ao questionamento sobre a mediação das educadoras, "quando, e se, é tematizado de alguma maneira, o gênero no cotidiano das crianças?". A participante localiza no estímulo familiar a origem do comportamento do menino em realizar atividades de limpeza, e não a um estímulo que parta da própria educadora, ou da creche. Santos e Silva (2013) relembram que os brinquedos, os objetos e estímulos destinados ao universo infantil são criação das pessoas adultas, pelo que essas entendem como sendo necessárias, ou pertinentes, ao seu desenvolvimento. Do mesmo modo, que a organização dos espaços, brinquedos e conteúdos na creche são carregados uma intencionalidade pedagógica, também, idealizada pelas pessoas adultas. Logo, os estímulos das educadoras são fundamentais a favorecer ressignificações dos modelos tradicionais de gênero 
[...] pois, propicia diretamente através de momentos específicos, a construção e a desconstrução de valores impostos socialmente, quando permite estimula o acesso a outras culturas, outros grupos sociais, outras etnias, enfim, novas vivências garantidas pelas inúmeras possibilidades do brincar possível a partir da prática pedagógica comprometida e voltada para os diversos conteúdos e discussões referentes inclusive, às questões de gênero (SANTOS, SILVA, 2013, p.7).

Outro texto obtido na busca bibliográfica nos apresenta outra tensão no trabalho docente na Educação Infantil. No trabalho intitulado $A$ generificação da docência na Educação Infantil: problematizando discursos presentes em livros de formação de professores, de autoria da professora brasileira Juliana Ribeiro de Vargas e do professor Rodrigo Saballa de Carvalho (2013), é feita uma análise sobre os discursos presentes em livros de formação destinados às educadoras da Educação Infantil. Há, nesses materiais, termos que exaltam a formação da figura da professora exemplar, admitida pelas habilidades relacionais, em que o afeto tem um grande peso, e de organização e presteza. Segundo Vargas e Carvalho (2013), as educadoras recebem uma formação em que é essencial haver uma separação das emoções pessoais, implícito um mecanismo de controle que delimita a vocação e a paixão pela profíssão acima da mulher. Como se fugir desse modelo correspondesse à educadora ser uma má profissional.

Essa interdição enquanto sujeita, em nome da profissional, é passível de interrogações, uma vez que tal imperativo possa influenciar as educadoras da Educação Infantil, como algo delimitador para a maximização da justiça social via escolarização, sob a perspectiva feminista, já que sua função como educadora, nas bases estudadas por Vargas e Carvalho (2013), se constrói sobre atributos domésticos, o que contribui a desvalorizar o trabalho das educadoras junto às crianças pequenas. Sendo assim, salientamos, concordando com Vargas e Carvalho (2013), a pertinência de uma reflexão sob a ótica feminista na Educação Infantil, para que as educadoras se reconheçam, enquanto mulheres e enquanto profissionais, mesmo porque cabe a elas a fundamentalidade de favorecer e estimular as brincadeiras das crianças, de modo a ressignificar as desigualdades de gênero, quando acessadas por elas.

Embora seja um indicativo de rompimento com modelos tradicionais, posto que é um menino que se ocupa com a limpeza e o cuidado com a sala de aula, e também esteja presente uma ressocialização da participação nas tarefas de cuidado e organização, isso não significa que a questão do compartilhamento de tarefas dos cuidados por parte dos homens no Brasil seja questão superada. Os argumentos para essa interpretação se baseiam em pesquisas demográficas e autoras feministas, cuja síntese apresentamos a seguir. 
A pesquisadora do Instituto de Pesquisa Econômica Ana Luiza Neves de Holanda, ao acessar dados do ano de 2017 fornecidos pela PNAD, informa que as mulheres se dedicam em larga diferença em número de horas às atividades domésticas, de cuidados com pessoas e com o lar. As mulheres dedicam $46 \%$ do seu tempo às atividades de cuidados, enquanto os homens investem $28 \%$ de seu tempo nessas tarefas. As atividades domésticas tomam $94 \%$ do tempo das mulheres, contra $79 \%$ do dos homens. Há a diferença de 37 pontos percentuais em tarefas que envolvem a preparação das refeições, cuidados com a roupa e limpeza da casa. Segundo a pesquisadora, os dados chamam a atenção para como as diferenças de tempo para as tarefas domésticas estão diminuindo entre as mulheres, mas não aumentando de modo significativo entre os homens. Sobre isso, Holanda (2017) aponta que, por parte das mulheres, aumentou-se as horas de lazer, e observa-se uma diminuição da jornada remunerada dos homens, o que requer uma análise mais aprofundada sobre a perspectiva de gênero nessa dinâmica. Esses dados são interessantes para pensarmos sobre o que se obscurece sob esses números. Se os homens têm tido menos tempo envolvidos em atividade laboral e se envolvem em alguma medida nas tarefas domésticas, conforme divulga a pesquisa, qual a razão de, mesmo ocorrendo essa mudança, as mulheres seguirem se ocupando em larga diferença com os cuidados com o lar? Podemos inferir que um caminho de desconstrução das relações de gênero vem sendo delineado, uma vez que há alterações com relação aos homens se ocuparem das atividades domésticas, em um indicativo de assumir essas obrigações.

Embora a pesquisa de Holanda seja um prognóstico positivo, não se sabe qual o grau de comprometimento desses homens com tais tarefas, e nem se essas tarefas são compartilhadas ou realizadas por homens que moram sozinhos. Logo, dados positivos não implicam necessariamente em transformações sociais significativas a ponto de afirmarmos que as mulheres $\mathrm{e}$ as famílias possam estar de fato sendo beneficiadas com $o$ compartilhamento das responsabilidades. Tanto que na creche pesquisada, sobre o envolvimento do menino com o cuidado com a sala, Larissa faz menção em seu comentário sobre o componente da memória - "menino que limpa por conviver com o exemplo da avó" que se afina com as análises de Devreux (2011). A autora localiza esse elemento como uma das influências na dinâmica das relações dos homens com os serviços domésticos, e conclui que os quadros de memória são sócio-sexuados: são sociais e também sexuados, pois essas memórias em específico não se associam à figura do pai.

De todo modo, a socialização não perde sua força, pois quando ela atua de maneira igualitária, é promotora de mudanças nas relações sociais, como na participação do menino 
em sala de aula, citado por Larissa, e na fala de Raquel, que diz que "Com o tempo, isso vem mudando, os homens vão mudando, do mesmo jeito que a mulher saindo para trabalhar, o homem pode se educar".

As participantes passam, então, a socializar suas descobertas sobre a presença das questões de gênero no cotidiano, ao observarem as crianças com um olhar mais crítico. Trouxeram questionamentos relativos ao uso de roupas e cores e da responsabilidade com a concepção e a maternidade, que geraram comentários diversos, tanto em apoio a posturas assertivas da mulher, quanto aqueles que, apoiados em juízos de valor conservadores, que comprometem a dignidade da mulher. Depois de todas se manifestarem, esta pesquisadora teceu considerações sobre as dúvidas das participantes, ao que participante Carla expressou:

“- Quando você falou é que são atitudes como essa que acaba em... né?! Continuando, continua o ciclo e a gente não vê e, assim, cansa de brigar sozinha, também, porque a gente ficar falando certas coisas e os outros ficarem '- Ah, não! Porque é bobeira", que não sei o que como se fosse uma coisa ruim, a gente, também, tem hora que a gente cansa, deixa pra lá, né...”.

Mesmo dando a entender que compreende ou acessa os mecanismos que naturalizaram as desigualdades que afetam as mulheres, e as discussões que apontam e propõem diminuir o preconceito, a descrença na mudança social apontada por Carla, por um lado, é perfeitamente compreensível, tendo em vista as múltiplas práticas que injustamente desprestigiam as mulheres, nas quais se invisibilizam as inúmeras sobrecargas, inclusive, as emocionais. Mas por outro lado, esse "desânimo" pode ser interpretado pelo prisma do antifeminismo, ou demonização dos feminismos. Tal temática é debatida no Brasil pela professora e feminista Rita Terezinha Schimidt (2006) e que é, definitivamente, altamente motivadora de Práticas não constituintes de cidadania, fato muito grave.

Em seu trabalho Refutações ao feminismo:(des)compassos da cultura letrada brasileira, Schimidt (2006) analisa que o termo antifeminista basicamente se circunscreve ao ato de refutar os feminismos, não em uma perspectiva crítica, mas por distorções dos conhecimentos propostos, "em várias modulações de sentido, presentes não somente na esfera pública de produção e circulação de bens culturais, mas surpreendentemente também na esfera institucional de produção de conhecimento" (SCHIMIDT, 2006, p. 765-766).

A análise da autora é precisa em apontar como os discursos veiculados na esfera jornalística brasileira foram, com afinco, uma das instâncias responsáveis por vulgarizar os Feminismos, omitindo suas produções de conhecimento e os desqualificando perante a 
opinião pública, em um recorte próximo ao que Susan Faludi realizou nos Estados Unidos, na obra Backlash: a guerra não declarada às mulheres (1985). Analisando essa tendência reducionista, Schmidt (2006) assevera que os setores de produção intelectual também exerce seu papel em rechaçar a abordagem dos Feminismos, articulando uma inteligibilidade científica e masculina.

Tal assertiva também foi apontada no texto Como pensar uma Epistemologia Feminista? Surgimento, repercussões e problematizações, da professora brasileira Patrícia Ketzer (2017). A autora pondera que o pensamento científico tradicional se construiu em uma perspectiva individualista, que desconsiderava o sujeito como um indivíduo corporificado.

Tal pressuposto pode ser observado, também, em outros momentos dos encontros formativos, debatidos no capítulo 4 da tese, como nas opiniões que expressaram desconfianças das mães que ocupam o tempo das crianças com atividades extras, com o intuito de cansarem as mesmas, sem considerar que tais atividades possam ser adotadas visando a promoção de conhecimento, cultura ou saúde. Ou ainda, quando participantes demonstraram contrariedade à atitude de mães que desabafam sobre suas angústias e sobrecargas. Tais comentários se afinam à perspectiva individualista uma vez que, além da invisibilização das mulheres, quando visibilizadas, as mães são admitidas como seres abstratos, como se não tivessem, ou não pudessem ter emoções, sentimentos, ou posturas que visem uma Educação externa aos seus cuidados e vigilância. Lembrando que tais modelos de comportamento foram, por muito tempo, veiculados por vozes de autoridade religiosas e também autoridades jurídicas, médicas, e, portanto, científicas, debates que constam nos capítulos 1 e 3 da tese.

Para ilustrar o argumento científico pautado na noção do individualismo, Ketzer (2017) aponta as construções sobre o sujeito cartesiano, cujo pilar principal reside em conceber que somente "um sujeito descorporificado que pode realizar atos de pura razão" (KETZER, 2017, p.97), descolando os indivíduos de suas emoções e vivências. Essa concepção só passou a se alterar na década de 1970, em que o conhecimento social passa ser reconhecido pelas comunidades científicas. Ketzer (2017) aponta que, concomitantemente ao surgimento da Epistemologia Social, nasce a Epistemologia Feminista, numa crítica que aponta a invisibilização das mulheres. Essa invisibilização é investigada sob a ótica da categoria gênero, inerente aos fazeres científicos, uma vez que essa abordagem revela desde a falta de reconhecimento na produção de conhecimentos, pautadas em desvalorização por supostos déficits cognitivos, quanto na construção estereotipada de sujeito descorporificado e 
individualista, cuja base teórica funda conceitos científicos consolidados, como a razão e a objetividade (KETZER, 2017).

Isso equivale a dizer que os Feminismos, como abordagem teórica, propõem outras construções epistêmicas, denunciando que os ideais de cientificidade privilegiam uma racionalidade masculina. Assim sendo, tal disputa também é política, pois se implica em uma disputa de poder, por reconhecimento, prestígio e legitimidade. Os conhecimentos "científicos" têm seu espaço nessas disputas, por sua indiscutível importância social. No entanto, no que compete às mulheres, e aos Feminismos, têm-se observado impactos perversos.

Ao longo da tese, foram explanadas as muitas contraofensivas direcionadas aos Feminismos, suas conquistas e buscas pela subversão das relações de gênero conservadoras e excludentes, nas quais a maternidade ocupa o lugar central (DONATH, 2018; TELES, 2003; PINTO, 2003; DEVREUX, 2011; MACKINNON, 2016). A partir de formulações que versaram sobre a romantização das maternidades, a contracepção, dentre outros temas, os Feminismos se depararam com a reação de múltiplas forças sociais e políticas que atuaram com o objetivo de fortalecer as dinâmicas patriarcais, diante do levante que desnaturalizava a dominação-exploração das mulheres.

De acordo com Meyer (2006), as manifestações das ciências médicas sobre a maternidade acarretaram na politização da amamentação, exercendo forte impacto na vida das mulheres. Mas, sobretudo, na relação dessas com os Feminismos, como assevera Badinter:

Defender o aleitamento a pedido, pelo tempo que a criança desejar, significa
simplesmente privar a mulher de um tempo para si. Quando a isso se
acrescenta que a sua presença perto da criança até os 3 anos é a melhor
garantia para o seu desenvolvimento, entendemos que todos os outros
interesses são secundários e moralmente inferiores. O ideal constituindo-se
em fazer suceder o face a face ao corpo a corpo. Embora o modelo seja
inacessível a inúmeras mulheres que não podem se dar ao luxo de ficar em
casa, e seja indesejável a inúmeras outras, pelo menos, se impôs. Nas mentes
e nas práticas (BADINTER, 2009, p.134).

A politização, discutida por Meyer (2006) e aprofundada por Badinter (2009) é fruto de reação de cunho naturalista, numa tentativa de retornar às idealizações essencialistas sobre a mulher. Ela pode atuar de diferentes maneiras, mas no aspecto do "desânimo" relacionado aos debates feministas, mencionado na fala de Carla, a politização das discussões assumiram, por conta do diálogo com a ciência, um caráter contraditório. 
O maternalismo tão defendido ainda não engendrou nem matriarcado, nem igualdade dos sexos, mas antes uma regressão da condição das mulheres. Regressão consentida em nome do amor que se tem pelo filho, do sonho da criança perfeita e de uma escolha moralmente superior. Fatores bem mais eficazes que as coerções externas (BADINTER, 2009, p.22).

Diante de todos esses argumentos científicos, as conquistas dos Feminismos, ao debater a contracepção, em desmistificar a maternidade e de buscar outros horizontes para as mulheres, são colocadas em termos de contradição, o que Badinter (2009) localiza como a grande virada ideológica, perceptível principalmente nas gerações de mulheres, filhas de mães feministas.

Elas procederam ao clássico acerto de contas das filhas em relação às mães. Depois dos agradecimentos de praxe pela contracepção e o aborto, vem a constatação de uma derrota. Derrota das mães que as filhas não querem imitar, e que se pode assim resumir: vocês sacrificaram tudo pela independência e, em lugar dela, assumem a jornada dupla de trabalho, são subestimadas profissionalmente e, no final das contas, são derrotadas em todas as frentes. Nessa crítica, o rótulo de "feminista" é rejeitado, como se apresentasse uma imagem desagradável das mulheres. A nova geração assumiu os estereótipos machistas mais gastos: aqueles que associam as feministas à histeria, à agressividade, à virilidade e ao ódio dos homens. $\mathrm{O}$ julgamento foi sem apelação: velharia. Mas por detrás da rejeição do feminismo se escondia outra crítica, mais íntima em relação às mães: a da concepção que tinham da maternidade. Talvez se possa compreender assim: "Você sacrificou tudo pela independência, inclusive a mim. Você não me deu bastante amor, bastante cuidado, bastante tempo. Sempre apressada, frequentemente cansada, você acreditou que a qualidade do tempo que você me dedicava valia mais do que a quantidade. $\mathrm{Na}$ verdade, eu não era a prioridade de suas prioridades, e você nunca foi uma boa mãe. Não repetirei isso com meus filhos" (BADINTER, 2009, p. 134-135).

A falta de interesse percebida na fala da participante denota um descaso com as heranças das conquistas dos Feminismos, pois ainda que vivenciemos muitos contextos de desigualdades, ainda, não superadas, usufruímos de diversos direitos adquiridos que, simplesmente, eram vedados às mulheres, como o acesso à Educação, ao mercado de trabalho, ao voto, e proteções sociais diversas das quais fazemos uso cotidianamente, o que constitui um olhar de anacronismo. A discussão sobre a existência de olhar incapacitante direcionado à mulher foi abordada pelas participantes relacionada ao trabalho da mulher na construção civil, tema no qual Sueli se manifestou da seguinte forma:

Essa questão de negócio de obra, eu já acho ruim... A mulher fazer muito esforço, a mulher vai carregar... o homem tem mais força. Ela vai se esforçar muito mais, ela vai trabalhar muito mais que o homem... Aí, quer dizer, uma 
pessoa para contratar uma mulher, um serviço desse vai querer comprar roda, vai querer que demora mais? Vai querer tudo mais rápido, tudo mais barato, com homem vai ser $[\ldots]$.

Faz-se pertinente retornarmos às movimentações antifeministas apresentadas por Schimidt (2006). Esse é o claro exemplo da estratégia desesperada de conservação da lógica patriarcal mencionada pela autora, e é como se remodelam os mecanismos ligados à incapacitação das mulheres, pela inteligibilidade. O comentário de Sueli coloca dois elementos fortes e inteligíveis culturalmente: a força física e a produtividade, que ao se conectarem, produzem um conteúdo de fácil acesso, vinculado ao sistema econômico. Assim, é criada uma representação, por meio de uma sutil e "sofisticada manobra de dominação em que se inscreve uma subjetividade com marcas que as vinculam aos interesses de um conjunto de sujeitos politicamente situados, localizados em um mesmo campo cultural e alinhados a uma mesma tradição" (SCHIMIDT, 2006, p. 769-770).

Diante desse contexto, e das realidades debatidas pelas participantes da creche-campo, talvez o possível "acerto de contas" com os Feminismos, tomando emprestada a expressão de Badinter (2009), atualmente, seja lutar para que os mecanismos de exclusão e dominação das mulheres sejam acessados na formação docente, estudados também na sua interface e impactos nos direitos das crianças, para que estes saberes não passem despercebidos às professoras e professores, uma vez que, também, é tarefa da escola favorecer a formação cidadã, pelas, e a partir das interações, contribuindo assim para a justiça social.

É a partir de contexto de influência de conteúdo anticientífico que os Feminismos e, também, os Estudos de Gênero são desprestigiados na área da Educação, como apontado na dissertação de Ramos (2016), mesmo com muitas contribuições teóricas e práticas na citada área, e em outras áreas das Ciências Humanas e Sociais, como a Antropologia, a Sociologia e a Geografia. Isso acarreta, além da formação de professoras e professores, em termos de romper com discursos incapacitantes ou inferiorizantes, um distanciamento da potência real dos Feminismos como movimentos sociais, na real possibilidade do contramovimento.

$\mathrm{O}$ antifeminismo e o anticientificismo consistem em atos antidemocráticos, já que se articulam movimentos de resistências à incorporação de pautas progressistas, tanto em termos de transformação social, quanto na produção da Educação. O artigo Gênero na Educação Básica brasileira: a inconstitucionalidade dos projetos proibitivos, escrito pelas professoras brasileiras Daniela Auad, Janaína Guimarães da Fonseca e Silva e Camila Roseno (2019) retratam como essas contraofensivas procuram atuar em distintos modelos de sociedade, 
desconsiderando completamente a ênfase de construção de uma justiça social pela via da Educação, contrários ao favorecimento do pensamento crítico.

O Movimento Escola sem Partido, exemplarmente, se mobiliza contrariamente aos debates sobre o gênero e a diversidade sexual nas escolas, em uma clara exclusão de toda a produção teórica formulada pelos Feminismos, Estudos de Gênero e pela Teoria Queer (AUAD; SILVA; ROSENO, 2019). Essa negação da produção intelectual é uma maneira de deslegitimar entendimento democrático já mencionado anteriormente, o de direitos iguais a todas as pessoas, desumanizando a população LGBTQIA e desmerecendo as lutas e demandas feministas. Além disso, as crianças também são afetadas, assim como, toda a sociedade, pois, conforme a citação se acessam:

[...] um mar de desinformação e contrainformação à opinião pública, querendo fazer crer que são inimigas da Pátria e da Família desde feministas até servidores públicos, assim como professoras, políticos identificados como do campo da esquerda e religiosos que venham a defender a consideração das temáticas pretensamente proibidas no interior das escolas (AUAD; SILVA; ROSENO, 2019, p. 571).

Ainda que mesmas autoras nos informem que iniciativas retrógradas que tem como foco a Educação, como a citada, não se sustentem, justamente pelo caráter inconstitucional, e irreal, porque as construções sociais e históricas sobre os corpos são desconsiderados por um discurso biologizante e moralizante (AUAD; SILVA; ROSENO, 2019), é pertinente salientarmos que a existência desse olhar, dito "científico", é nocivo à produção e interação pedagógica em todos os níveis de ensino, não somente à Educação Infantil, pois limitado, limitador e alienante às desigualdades das mulheres, conferindo a elas a reprodução de uma cidadania incompleta.

Logo, reposicionar as questões formativas também faz parte do desafio de maternar em perspectiva feminista. Tal premissa é corroborada pelo texto da professora brasileira Daniela Finco (2013), cujo título é Igualdade de gênero nas instituições de educação infantil brasileiras. Ao versar sobre os desafios de implantação da agenda de igualdade de gênero na Educação Infantil, principalmente, em outros olhares para as feminilidades e masculinidades, em oposição aos conhecidos modelos sexistas, debatidos na presente tese, como a "ausência de ações que garantissem a devida implementação de novas exigências para a prática docente nas instituições escolares" (FINCO, 2013,p. 87), o que também está em consonância com as análises dos discursos políticos proibitivos de Auad, Silva e Roseno (2019) no cenário político brasileiro. 
Assim sendo, subverter o conservadorismo de gênero pelo aparato educacional garantiria uma educação voltada à democracia desde a infância, garantindo a elas uma cidadania plena e ativa. Ao lado disso, as autoras das obras de referência e dos textos da pesquisa bibliográfica, como Louro (1997), Auad (2003, 2006) e Finco (2013) são categóricas, tanto em apontar a importância da igualdade de direitos, quanto em nos advertir sobre as construções das crianças e as questões de gênero pela via da Educação, e Educação Infantil.

Pesquisas sobre gênero e infância revelam que, em face da opressão que as crianças e as meninas sofrem, elas param de se exercitar em suas habilidades mais amplas, param de experimentar, inventar e criar; o jeito que eles são educados pode contribuir para se tornarem mais completos ou, por outro lado, para limitar suas iniciativas e aspirações (FINCO, 2013, p. 86).

Considerar a perspectiva feminista na Educação pode, também, auxiliar na aparente atualização da opressão das mulheres, pela valorização da força física, como relatado por Sueli. As mulheres são capazes de realizar quaisquer trabalhos. Qualquer afirmação em contrário corresponde a um rebaixamento do trabalho das mulheres, o que corresponde a uma crença frágil, e não a uma capacidade de ação efetiva.

Sobre todo o quadro exposto, o texto $O$ que há de errado com a democracia liberal? (2011), escrito pela feminista e cientista política estadunidense Anne Phillips nos oferece pistas para refletir sobre as discordâncias existentes sobre o fenômeno da democracia liberal, em que de um lado, alguns defendem a manutenção do status quo, e de outro, há a discordância de que o liberalismo seja suficiente a uma cidadania plena, haja vista a produção das desigualdades, da exploração e dos padrões mínimos de intervenção do poder público. Esse debate, segundo Phillips, se dá por diversos ângulos, como o feminista, o da participação social e o republicano.

A democracia liberal deseja ignorar (e o republicanismo cívico deseja transcender) todas as identidades e diferenças mais locais; na realidade, as duas tradições insinuam o corpo masculino e a identidade masculina em suas definições da norma. Os democratas liberais, em particular, acreditam ter estendido todos os direitos e liberdades necessários às mulheres ao permitirlhes o voto nos mesmos termos dos homens. Isso é simplesmente inadequado, como até os indicadores mais crus (como o número de mulheres na política) mostram. A democracia não pode pairar acima da diferença sexual, mas tem que ser redefinida com essa diferença em mente. Uma implicação óbvia é que a democracia deve lidar conosco não apenas como indivíduos, mas como grupos (PHILLIPS, 2011, p.341). 
Uma grande e conhecida máxima do liberalismo "insiste em que as diferença entre nós não devem importar" (PHILLIPS, 2011, p.343) desconsiderando o fato de que as sociedades são governadas por grupos de interesses. Isso coloca o debate das ações afirmativas como redistributivas da justiça, pois são necessários “arranjos especiais para garantir uma presença igual" (PHILLIPS, 2011, p.349). Isso constitui um desafio, pois a representatividade política é sim, muito importante, contudo, nem sempre corresponde a um avanço social significativo para os indivíduos enquanto grupo.

Argumentos que desprezam a relevância política da esfera privada estão contribuindo para manter as coisas como estão, pois nos encorajam a considerar que tudo vai bem a despeito do que deveria ser considerado como grandes contradições. A tirania doméstica, por exemplo, é e deve ser considerada como inteiramente em contradição com a cidadania, pois, por trás da fachada dos direitos iguais à participação e ao voto, ela segue como antes da luta por esses direitos e sua conquista.

Logo, a situação das mulheres e das crianças, no que refere à igualdade formal reconhecida, seguem com mudanças refratárias e pouco substanciais. A igualdade formal promete o pleno acesso aos direitos e recursos públicos, mas não os cumpre, na forma da insuficiência das creches, na formação docente também insuficiente no que tange à profundidade das questões sociais. Isso equivale à dimensão de uma cidadania incompleta que atinge as crianças e as mulheres, pelo que foi apurado nos encontros formativos.

É por essa razão que as feministas questionam a "mistura implausível de igualdade formal e subordinação privada" (PHILLIPS, 2011, p. 351), pois se a igualdade formal, ou o acesso ao voto e a participação política seguirem orientadas por relações de subserviência ou patronagem, a sociedade não é democrática. É no olhar sobre essa diferença de "peso" que reside uma das maiores contribuições dos Feminismos, que ao debaterem a democracia pelo gênero, recuperam as bases do republicanismo, em que todas as pessoas deveriam ter o mesmo peso, ainda com suas diferenças, aqui intrínseco o aspecto da liberdade.

Desse diagnóstico, Phillips (2011) nos descortina que a maior participação, desejada pelos Feminismos, é a condição necessária a menor discriminação de mulheres e homens, o que fortalece a democracia ativa. Segundo a autora, o que se perde com a adoção de padrões mínimos do liberalismo, e com a excessiva ênfase de quem pode opinar é quem sente a experiência, é que todas as pessoas deveriam ser chamadas a pensar sobre todas as demandas da sociedade. 
Essa crítica da autora é extremamente válida numa nuance que foi pouco abordada nos encontros formativos: a responsabilidade dos homens com relação às crianças. Segue o reconhecimento da importância da corresponsabilidade, na forma da escola, da creche, do poder público e da família, mas na prática, a família continua sendo convocada pela figura da mãe. Desta maneira, um possível caminho para a consolidação da maternagem esteja na socialização dos homens nesse intento.

\subsection{AS DISPUTAS DE PODER NA CRECHE: UM TERRITÓRIO DEMOCRÁTICO EM POTENCIAL}

Diante do panorama acessado nos seis encontros formativos realizados na crechecampo, foi possível observar as maneiras que as construções sociais sobre as mulheres, as crianças, a instrução formal e a maternagem, no movimento educativo empreendido pela creche, se conformam e se expressam.

Pelo movimento de busca bibliográfica, obras de referência feministas e bibliografia de apoio, consideradas a posteriori pela expansão dos temas de influência ao olhar de pesquisa, pudemos compreender que a creche, enquanto espaço físico e institucional, de maternagem extrafamiliar, produz outros espaços. Espaços esses, também simbólicos e híbridos, pois perpassados pela temporalidade, historicidade e pelo político. Tais espaços, físicos ou não, podem ser denominados como territórios, conforme o olhar de Haelsberg (2004), no qual nos amparamos para desenhar a produção de territórios democráticos, pela ação de interlocução das mulheres, como exposto nos capítulos 2 e 3.

Partindo desse pressuposto, e considerando o movimento dialógico apurado, que aponta disputas e conflitos relacionados aos currículos, aos olhares para as mulheres e crianças enquanto sujeitas, as relações homem/mulher, mulher/família, a responsabilização com os cuidados, a agência das crianças e o olhar profissional e político, é possível apontar que a creche se conforme como um território em potencial, atravessado pelos saberes docentes, pelas vulnerabilidades e pelo comprometimento daquelas e daqueles que trabalham, pedagógica e politicamente por uma Educação Infantil de qualidade, defendida pela presente tese na promoção de uma educação política, em perspectiva feminista.

Os dados dos encontros formativos trazem manifestações de práticas e entendimentos profícuos à construção de uma cidadania ativa (BENEVIDES, 1994), na qual as pessoas possam ter as ferramentas necessárias a abrir novas participações políticas, como explicitado 
no capítulo 1. O movimento inverso também se faz presente, na forma de resistências, desconhecimentos ou banalização das desigualdades provocadas pelo gênero, classe, raça e geração, nos possíveis agrupamentos dessas categorias, em expressão nos cotidianos da creche pesquisada, e na expressão social de cidadanias incompletas.

De todo modo, esse caráter ambíguo ilustra justamente o que Araújo (2012) e Beréngere-Pereira (2009) apregoam ao analisar a dimensão da cidadania, ao pressuporem a importância de todos os sujeitos e sujeitas, bem como seus lugares e vozes. Tal dinâmica, que, em considerar legitimamente as múltiplas vozes, como as das minorias sociais, especialmente as mulheres e as crianças, provoca conflitos e disputas, mas são justamente o que entendemos por democracia, em espaço dialógico e agonístico, em concordância com o que define Mouffe $(2003 ; 2005)$.

Ainda que as reflexões dos encontros formativos tenham adquirido dimensões antagônicas em muitos momentos analisados nos capítulos 4 e 5, identificamos movimentação democrática pelo dissenso. O dissenso, conforme Mouffe (2003; 2005), fomenta o exercício de interpretação, análise e julgamento na resolução das demandas, condição esta que, mobilizando as citadas habilidades, condizem com um processo educativo emancipador.

Entendemos que, enquanto território, a creche é potencialmente democrática, uma vez que nesse espaço se comprovou ser possível debater sobre as construções sociais ao longo dos tempos, mobilizando, ou despertando, o enfoque político por quem também é responsável por mediar o percurso da Educação desde o nascimento. Nesse território, também estão presentes condições estruturais e controles sociais relativos às mulheres e às crianças, não tão subjacentes ou distantes quanto as participantes supunham, já que reconheceram que suas práticas concretas são, por vezes, mediadas pelas contradições sociais.

Muitas vezes, elas exclamaram: "Eu não tinha pensado nisso", ou "A gente acha que não tem, e tem", num claro movimento de ressignificação de consciência, mesmo com as discordâncias de pontos de vista sobre alguns temas. Haelsbert (2004, p. 20), ao apontar que "o território pode inspirar a identificação (positiva) e a efetiva "apropriação"', nos conduz a associar as declarações das participantes como as marcas do vivido, nos encontros formativos. Neles, o que foi vivido, relatado pensado e compartilhado se deu pela inserção de olhar feminista, que ao tematizar as mulheres, trouxe com elas, e por elas, uma reflexão sobre a interface dos direitos das mulheres e os direitos das crianças. Ao nos propormos, por meio dos debates dos encontros formativos, a desembaraçar a relação entre a forma e o conteúdo, o reconhecimento formal e o real, é proporcionada a ressignificação de nossas consciências, 
enquanto mulheres, do modo como Mackinnom (2016) apontou pertinentemente como fundamental: "a questão da mulher" é compassivamente analisada em relação à outras questões, ao invés de ser vista como "a" questão. Desse modo, ao falarmos, em um grupo de mulheres sobre nossas convicções, socializadas e também ressocializadas, seguramente, tal ato relaciona-se com a construção da cidadania pela Educação. 


\section{RESSIGNIFICAÇÕES NADA FINAIS}

Figura I. 1: É necessária a aldeia inteira para educar uma criança.

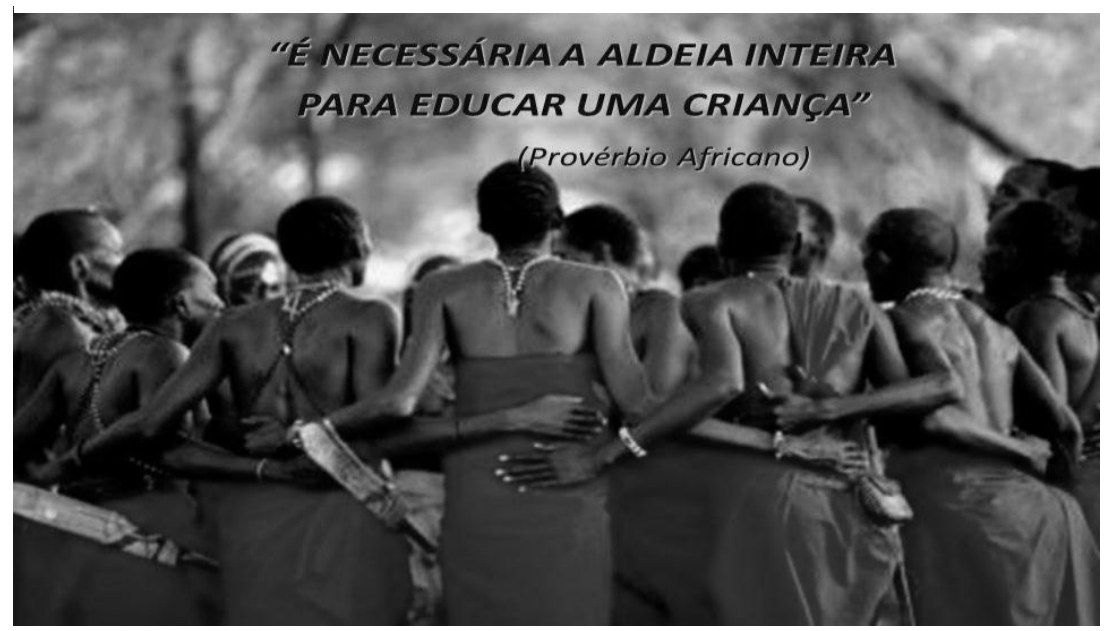

Fonte: www.fablablivresp.prefeitura.sp.gov.br

Das muitas identidades que nos habitam, algumas, potencialmente latentes, orientaram a construção desse texto. Como mães, mulheres e professoras feministas, a Educação nos toca de muitas maneiras, justas e injustas, mas também é tocada por nós, em outras formas de conhecer. Nessa dinâmica, partilhamos nossas estradas com as crianças, as formando, educando e nos vinculando de modo pessoal, íntimo, profissional e político. Sensíveis às mulheres e às crianças, a tese tem foco duplo, comprometida com os direitos de ambas.

A presente tese buscou conhecer como se dá a maternagem na creche. Estabelecido esse objeto de pesquisa, delimitado e instigado por estudos de perspectiva feminista, a necessidade primeira a ser identificada foi a de nos embrenharmos em pesquisa teórica, a fim de compreender os conceitos envolvidos na proposta de pesquisa, e a forma com que eles perpassam as mulheres, e também as crianças. O olhar de feministas como Mollo-Bouvier (2005), Scott (1994; 1995), Saffioti (2011), Teles (2003) e outras autoras nos auxiliaram a compor como a categoria gênero é elemento estruturante nas construções políticas e sociais direcionadas às mulheres, principalmente ao versarem sobre o gênero, os cuidados, o trabalho, a maternidade, a socialização e a cidadania.

Já os pressupostos democráticos, debatidos por Benevides $(1994 ; 1996)$ e Mouffe $(2003 ; 2005)$ descortinaram sobre a construção da democracia, dentro e fora da escola, o que nos rendeu elementos para refletir e seguir no desejo de fomentar transformações nas ordens sociais desiguais que tocam as mulheres e as crianças pelas socializações. Ao vincular tal debate à Educação, a tese considerou que uma mudança nas socializações de gênero poderia 
ser promovida pela maternagem, se identificada e debatida fosse, reconfigurando a contradição entre um contexto social formalmente reconhecido em termos de direitos iguais, e um contexto real de desigual sobrecarga às mulheres, comumente inferiorizadas socialmente, e demandadas de modo especial à responsabilidade de maternarem as crianças. Para tal, sugerimos debate político que recupere o compromisso da corresponsabilidade da família, do Estado e da sociedade em educar as crianças, como já estabelecido pela Constituição Federal brasileira.

Além de debate racional, e democrático, sobre o tema, e ressocialização da maternagem como tarefa de todas as pessoas, envolvendo a família, as escolas, órgãos de proteção e de serviços extrafamiliares, se faz pertinente a consideração de que tal propósito possa se concretizar por via de elaboração de política pública, a fim de consolidar-se enquanto compromisso e pressuposto de justiça social. Contudo, o diálogo proposto, ao nos atravessar, também, enquanto professoras, aponta também para um processo de ressignificação individual, no que a perspectiva feminista se expressa como transformadora do entorno, e de nós mesmas, ao fazer pensar práticas pedagógicas comprometidas com abordagens feministas e antirracistas, o que nos impele a desnudar os fenômenos de influência ante a formação docente e também humana.

De volta ao foco duplo - mulheres e crianças - a etapa seguinte da pesquisa teórica se deu em duplo movimento, tanto no mapeamento das trajetórias dos Feminismos, quanto da construção da Educação Infantil, especialmente no que tange a apresentar e entender os processos de democratização social, da criação ao reconhecimento das mulheres e das crianças como cidadãs. A creche nasceu como bandeira de luta das mulheres, com o primeiro propósito de atender às necessidades laborais, e foi adquirindo outros contornos a partir das preocupações das mulheres com a qualidade do atendimento, respaldadas também pelos avanços científicos que passaram a privilegiar os aspectos relativos às infâncias, ao lado das discussões políticas e sociais que reconheceram a criança cidadã, ativa em suas construções e em seus fazeres de mundo.

Ao analisarmos esses processos, observamos que eles, ao envolverem a interlocução e o debate, que possibilitam diálogo com visões distintas sobre os temas tratados pela tese, são grandes as possibilidades de surgirem reinterpretações, ou contraprocessos que, em alguma medida, até pelo próprio surgimento, transformam e alargam o panorama argumentativo das disputas políticas. Esse alargamento produz uma ressignificação desses espaços, ainda que não consensuais. Desta forma, compreendemos que há a produção de territórios, pelas 
disputas de força e poder contidas nessas elaborações, genuinamente democráticas, e democratizadoras.

O percurso dos Feminismos e lutas por igualdade de gênero e creches na Europa foi explorado a partir da análise da obra das feministas Anne Bucas-Français, Jacqueline PenitSoria e Nicole Savey. Com esse mesmo foco, também acessamos as batalhas das mulheres na América do Sul, pela ótica do texto das professoras Nancy Saporta Sternbach, Marysa Navarro-Aranguren, Patricia Chuchryk e Sonia E. Alvarez (1994). Em especial, as lutas feministas e demandas por creches no Brasil foram apresentadas pelo olhar de Amelia Teles, Céli Pinto, Fúlvia Rosemberg, Zilma Oliveira, Roselane Campos e outras autoras. A partir delas, pudemos compreender como os movimentos feministas e de mulheres foram construindo sua participação social e política, favorecendo, por meio suas demandas específicas, discussões que revelaram as desigualdades criadas por relações baseadas em opressões sociais, políticas e econômicas. Assim como as mulheres, as crianças pequenas são vulnerabilizadas pelas desigualdades sociais que afetam suas mães, avós ou responsáveis, invisibilizadas também pelo mesmo movimento de opressão social de que sofrem as mulheres: o de negação das questões que produzem a pobreza e a exclusão social (CAMPOS, 2011).

Fazer esses paralelos nos indicou que as crianças que têm menos acesso a creches e escolas de Educação Infantil são aquelas pertencentes aos extratos mais pobres da classe trabalhadora, o que é agravado, também, pela raça (ROSEMBERG, 1994). Diante desse cenário, a situação de desigualdade e vulnerabilidade das infâncias, ao coexistir com a situação da criança cidadã é um dos pontos de interesse do debate dessa tese na tensão com a cidadania da mulher-mãe. Essa confluência reflete-se no equipamento da creche-ocupada em sua maioria por mulheres - dado constatado também em artigos e pesquisas desenvolvidas, na graduação em Pedagogia e na pós-graduação. Esse fato, e a relevância sobre o olhar de construção da cidadania foram pressupostos nos quais nos amparamos na tarefa de realização de retrospecto sobre a Educação Infantil brasileira, no sentido de compreender como tais construções se deram, e como as mesmas se reverberam em município mineiro. O movimento de educar as crianças, presente nas creches, coloca a mesma como corresponsável pela educação, em uma perspectiva que se propõe, pela legislação vigente, a ser integral, o que implicita o enfoque das categorias mencionadas neste texto, ou seja, o gênero, a classe, a raça e a geração. 
Politicamente, a Educação Infantil brasileira nasce impregnada com uma visão assistencialista e salvacionista ante a pobreza, e o grande salto ocorreu quando passou a integrar a Educação Básica no ano de 1996, em prescrição da LDBEN. A Educação Infantil foi percorrendo uma trajetória de debates que foram incorporando tanto os avanços teóricos sobre as infâncias, quanto o reconhecimento da criança como cidadã de direitos, convivendo com tensionamentos que correspondem a desafios de concretização de ordens material, pedagógica, política e operacional, que puderam ser acessados pelas produções de Nunes, Corsino e Didonet (2011), Rosemberg (1984; 1994; 1999), Alves (2016) e Zanetti (2015). Desse modo, pensar a Educação como um direito é considerar questão atravessada por várias faces de ação política, social e profissional, como demonstram os documentos da Educação Infantil, construídos em meio a intensos diálogos com professores, professoras, comunidade acadêmica, Conselhos educacionais, entidades civis e movimentos sociais, mapeando as dimensões envolvidas nos trabalhos com as crianças, como a formação, o currículo, a infraestrutura, o financiamento, a ação complementar às famílias, a avaliação, entre outras.

Inseridos nesse contexto político, os contextos educacionais, tanto nacional e municipal, realizam debates que trabalham no sentido de valorizar a criança, enquanto sujeitas e cidadãs. Em consonância com a Constituição, o Estatuto da Criança e do Adolescente e a LDBEN, as práticas pedagógicas da Educação Infantil devem se basear, como recentemente recupera a BNCC, em fomentar as experiências, o que nos coloca a importância da socialização, elemento chave à discussão proposta pela tese. Fundamentalmente, as interações das crianças, inclusive com as pessoas adultas, devem se dar de maneira dialógica, em um movimento de conhecer o eu, o/a outro/a e o nós, em linguagens como a brincadeira, a musicalidade e a literatura, e outras, a fim ampliar o seu conhecimento de mundo, social e cultural, considerando e acessando múltiplas realidades. Nesse sentido, é apontada como pilar as necessárias e conhecidas discussões sobre a formação docente, inicial ou continuada, especialmente no que tange às suas intencionalidades pedagógicas.

No entanto, a interdisciplinaridade necessária à promoção de um atendimento integral, e as discrepâncias de acesso, na forma das matrículas, quando analisadas comparativamente por regiões geográficas, são alguns dos fatores que a bibliografia acessada localizam como elementos a serem pensados sobre os atravessamentos ao direito à Educação. Também é fator relevante a proteção aos direitos sociais, tocados pelo setor assistência, que é um direito, e a consideração de distintas realidades, a fim de tornar as construções de conhecimento infantis mais desafiadoras e amplas. Esse ponto também toca as DCNEI, que 
ao flexibilizarem os currículos da Educação Infantil, em parte diversificada a ser explorada pelas instituições educacionais, estabelece o espaço de interlocução com os contextos sociais das crianças e famílias de modo a enriquecer os processos educativos e estabelecer a parceria com a corresponsabilidade na Educação.

Assim sendo, foram se desenhando as disputas e conflitos em torno da Educação. Em relação aos eixos de conhecimento a serem contemplados, há a recusa em abordar as questões de gênero e sexualidades nas escolas, pelos setores conservadores da sociedade, num claro posicionamento de manutenção das hierarquizações e exclusões sociais que afetam as mulheres e outras minorias. Para nós, segue como questão difusa o que, e em qual profundidade, visibilizar das realidades sociais nos trabalhos pedagógicos da Educação Infantil, pois todo o quadro político exposto se coloca em contradição aos princípios basilares desse nível de ensino, e do direito a uma Educação emancipadora e cidadã.

Ao lado disso, o trabalho da mulher - seja ele na creche ou não - é duramente impactado pela (não)cobertura das creches, um forte fator que promove a desigualdade da participação das mulheres no mercado de trabalho e, em consequência disso, a discrepância em termos de renda para além das já conhecidas diferenças salariais entre mulheres e homens. A questão do acesso ao mercado de trabalho persiste. Mesmo porque, diante das sociabilidades contemporâneas em que as mulheres exercem um papel considerável, também perante o ato de prover o lar, a suspensão de suas atividades laborais por um grande lapso de tempo impacta a situação financeira de suas famílias. Como atualmente é impensável o retorno das mulheres ao âmbito do lar, compreende-se o porquê de muitas mulheres se sentirem desencorajadas a vivenciar a maternidade, tanto pelo peso da responsabilidade para com as condições materiais necessárias à educação das crianças, quanto pela culpabilização difundida socialmente de que uma mãe deve à criança todo o suporte emocional e afetivo (BADINTER, 2009) o que destoa e desconsidera tanto as suas pretensões pessoais quanto a participação de outras pessoas, do Estado e da sociedade como um todo na obrigação de maternar.

Isso foi apontado no recorte histórico dos embates feministas na luta por creches, frente a distintas concepções políticas e sociais dos governos, bem como as regulações econômicas de organismos internacionais no Brasil e em vários países do mundo que interferem no apoio financeiro e ideológico conferido à Educação e aos mecanismos de cuidado das famílias (BUCA- FRANÇAIS, PENIT-SORIA, SAVEY, 2006; TELES, 2003; CAMPOS, 2012). 
Em contexto brasileiro, vale lembrar que o conceito de vulnerabilidade social se sobressai ao direito à Educação. É fundamental o papel do poder público na interferência e no provimento aos direitos e proteção das crianças, como na atuação e fiscalização dos Conselhos Tutelares, e na promoção de políticas de combate à violência de gênero sofridas pelas mulheres, como apontado em conclusões de pesquisa de Mestrado (RAMOS, 2016) já mencionada em outros momentos. A pretensão da tese foi debater a identificação de uma sutileza nesse mecanismo: o necessário controle social, exercido pela interferência do poder público concorre a não distribuir a responsabilidade social para com os direitos das crianças, mas a visibilizar apenas a figura da mãe no cumprimento das obrigações com as infâncias, o que pode ser antidemocrático. Isso obscurece a real obrigação de comprometimento de outros agentes sociais, estabelecida por lei, com a educação das crianças, o que configura uma desigualdade a ser debatida e superada.

Essas tensões foram apresentadas e discutidas com a equipe da creche participante da pesquisa, se propondo a debater sobre a maternagem na creche, em dimensionar e propor reflexões sobre o controle social sofrido pelas crianças e pelas mulheres, tocadas pela vulnerabilidade social e econômica, assim como o papel das políticas sociais e dos Conselhos que asseguram e debatem sobre os direitos desses grupos, notadamente perpassados pelas questões de classe, gênero, raça e idade.

A partir das impressões das participantes dos encontros formativos, o panorama geral de pesquisa apurou as principais interfaces que compõem a imbricação desses dois grupos. A questão dos cuidados com as crianças seguem associada às mulheres, ainda que a creche se reconheça como parceira nessa tarefa, o que faz uma alusão à perspectiva de maternagem proposta por essa tese. Mesmo assim, as participantes dão a entender que essa parceria tem sido, na maior parte do tempo, somente prática, na atenção com os cuidados e necessidades das crianças, e na forma de preocupações com as situações de vulnerabilidade social.

As contribuições das participantes puderam demonstrar que, na creche, coexistem entendimentos que constroem uma Educação que amplia os modelos de comportamento pautados no gênero, como em relato de educadora que contrapôs o fato de um menino brincar de cozinhar, quando perduram entendimentos que reduzem o potencial da experiência educativa e de formação da criança, como no caso da educadora que não demonstrou sensibilidade em propor o exercício da socialização de uma criança que não dividia seus objetos, sugerindo que tal situação se solucionasse com a vinda de um irmãozinho. 
Ainda que sensíveis às questões individuais das mulheres-mães, observa-se um distanciamento das participantes enquanto mulheres, na maneira apressada em responsabilizar ou classificar negativamente as condutas das mulheres-mães das creches, num claro movimento de diferenciação. Parece-nos que o papel profissional é concebido como adequado quando afastado do olhar enquanto sujeitas em um movimento de desumanização da professora, processo que se soma as muitas manifestações de descredibilização e inferiorização social direcionados às mulheres, como o real controle social sobre o exercício da maternagem.

De acordo com os relatos das participantes, as mulheres são a maioria absoluta da família que acessa a creche, socializando conflitos sobre a educação das crianças e de outros aspectos de suas relações, nas quais os homens se fazem ativos nas socializações de gênero das crianças, interferindo de modo polarizador nos comportamentos e brincadeiras, com a finalidade de manutenção de sua autoridade e da heterossexualidade compulsória (RICH, 2010). Também foram relatadas outras posturas, em que os cuidados de si e o compartilhamento de brincadeiras e de tarefas de cuidados com o lar e com a família não são dicotomizados pelos sexos, o que nos faz pensar que existem caminhos sendo percorridos rumo à igualdade de gênero, tanto em âmbito doméstico quanto nos olhares presentes no espaço da creche.

$\mathrm{Na}$ prática, fica demonstrado que é possível reconstruir a maternagem pelo envolvimento com outros modelos de comportamento, ou seja, outras referências, mais democráticas, e menos estigmatizadoras e desiguais. De todo modo, Michael Apple (1982) nos adverte pertinentemente sobre a complexidade das estruturas que atuam nos mecanismos de dominação aqui descritos, e que não basta somente nos posicionarmos ante os valores que escolhemos, ainda que isso também seja de suma importância:

Se o que aprendemos fosse somente uma ideologia imposta, ou se fosse apenas os significados e práticas isoláveis da classe dominante, ou de um setor da classe dominante, que é imposta a outras, ocupando somente o topo da nossa mente, então seria - e com isso nos daríamos por satisfeitos - uma coisa bem mais fácil de derrocar (APPLE, 1982, p.16).

Assim sendo, se fazem necessárias reflexões mais aprofundadas sobre os instrumentos jurídicos, médicos e educativos, que tendem a difundir e reproduzir olhares naturalizadores sobre as ações dos homens, das mulheres e das crianças, pois essa insuficiência penaliza as crianças pela socialização de conhecimento insuficiente, sem as capacitar em questionar os 
por quês. Não vislumbramos no momento outra maneira que contribua a capacitar para o questionamento que não seja a visão agonística de Mouffe (2003), pois princípios baseados em consensos falseados não abarcam as contradições e crenças humanas. Recente exemplo disso foi relatado em parte no capítulo 5, nas falas sobre o aborto do Dr. Olimpio Barbosa, ao contar como parte das retaliações que sofre por realizar abortos legais, inclusive, em crianças, coexistem com a compassividade oportunista que por vezes acoberta os mecanismos do aborto ilegal no Brasil.

Outro exemplo de como isso se materializa é o ideário da mãe-má que abandona suas crianças na creche, conforme debatido nos encontros formativos. Deixar as crianças na creche não corresponde a se livrar de um fardo, mas sim a uma busca pela sobrevivência e pela construção de seus anseios, por parte das mulheres, e um direito da criança, a usufruir de uma Educação. A força de uma referência cristalizada, de uma mãe ideal e da sacralização do lar como espaço ideal para a criança, secundariza o direito dela de ser educada em ambiente extrafamiliar, profissionalizado, desde o nascimento, invisibilizando relação garantida por lei, que garante o compartilhamento dessa responsabilidade da família com outros entes, de modo complementar, socializando expectativa social deturpada e antidemocrática.

É nítido o movimento das disputas de poder - em sua maioria, em perspectiva retrógrada - que perpassam os currículos da creche - e da Educação como um todo - que reduzem os debates sobre o reconhecimento às minorias sociais sobre o direito ao respeito, de modo automático. Evidentemente, as ações e práticas precisam ser respeitosas, mas se observou, pelas contribuições das participantes, que os olhares da creche seguem invisibilizando os públicos que atendem, pois a raiz de todos os problemas, e a busca por solução desses - segundo elas - estariam na socialização primária, ou seja, na família. Acreditamos que isso se dá como efeito dos ataques que as escolas e instituições de ensino vêm sofrendo como espaços formadores, enquanto espaços de questionamento e pensamento crítico, principalmente em relação aos grupos historicamente marginalizados, as desigualdades sociais e a lógica desumanizadora do liberalismo enquanto sistema econômico. Esses fatores também se revelam como complicadores por interferirem nos processos de identificação das mulheres, enquanto mulheres.

Esse movimento equivale ao que Apple (1982) situou como o mecanismo de conservação das hegemonias. Em exercendo poderes políticos e econômicos, a Educação é influenciada, pois ao estar imersa nesse contexto, pode atuar na (re)produção do esvaziamento dos significados sociais contidos nas relações sociais e na socialização dos conhecimentos. 
Em comumente sendo socializados de maneira descolada de uma compreensão política e econômica, a Educação tende a contribuir na alienação sobre as produções e atividades de homens e mulheres, em cada contexto histórico, no que precisamos estar alertas a fim de, ao encarnarmos uma argumentação tipicamente hegemônica, a de uma postura suposta "neutra" que definitivamente não existe - deixarmos de cumprir a nossa função de educar, de modo democrático, pois a omissão de produção intelectual acerca das realidades constitui ato alienante, que não cumpre com os pressupostos de uma Educação voltada à justiça social, nem com as expressões dos Direitos Humanos.

Desse modo, os textos e obras aqui discutidos demonstram que, mesmo com propostas políticas concretas de emancipação e superação das desigualdades sociais e educacionais, mulheres e crianças continuam a ser interpretadas e atendidas de modo desigual, o que fere a condição de cidadania conferida pelo Estado Democrático de Direito, no qual se insere a igualdade social. Em sendo estabelecida por lei e buscada incessantemente por movimentos sociais que reivindicam tal condição, no que tange à Educação, é imprescindível que essa área contribua em fomentar o olhar político aos conhecimentos e as relações sociais. De modo objetivo, as reflexões geradas nos encontros formativos permitiram descortinar as tensões envolvidas em contexto formativo profissional, na operacionalidade das políticas educacionais, nas relações familiares e os tons de diálogo com os direitos e as vulnerabilidades sociais. Subjetivamente, apurou-se que as participantes se apoiam também na sua formação humana e pessoal, e nas situações concretas a que acessam, pautando-se pelas indicações da gestão da instituição. Ainda que ativas em cursos de formação continuada, há uma lacuna na socialização de conhecimentos formativos que pensem sobre a relação entre a desnaturalização das desigualdades sociais e a Educação, curiosamente, e justamente a seara que dispõe de instrumentos a essa discussão.

Essa contradição pode ser reinterpretada se adotada uma perspectiva de análise feminista, pois apontam o cerne dessa contradição, confirmado pelas falas das participantes: a ideia consagrada do amor materno, como debatido nas obras de Badinter (1985; 2009) e Chodorow (1990). Do contrário, a sociedade segue naturalizando conhecidos modelos de idealização da figura da mulher, como a injusta divisão de tarefas e responsabilidades com os cuidados e Educação e a expectativa social da obrigatoriedade de parir. Nada disso é formulação inédita aos Feminismos, deslegitimados enquanto epistemologia pelas disputas de poder politico no âmbito científico. O que essas relações de poder não previam é que sua mobilização em desprestigiar os movimentos feministas ia se deparar com uma condição de 
pandemia, que mundialmente visibilizou, inegavelmente, todas as relações de desigualdade social, sobrecarga e violência que afetam as mulheres, e também as crianças, dentro de seus lares.

É de muita urgência considerar as contribuições das áreas de conhecimento e dos movimentos sociais sobre os direitos das mulheres e os direitos das crianças, pois as tendências observadas nos dados de campo e nos históricos recuperados ao longo da tese se colocam de modo extremo, deturpando os direitos de decisão sobre se ter uma família, ou não, e quem educa as crianças, ou não. Em toda a sociedade brasileira, o aborto e a concepção são concebidos de maneira intransigente, transitando de um polo a outro, de maneira irrefletida. Tanto que coexistem mobilizações antiaborto, do mesmo modo em que ocorreram movimentos de esterilização em massa ocorrido no Brasil, e essa modalidade de contracepção segue forte no ideário de quem pretensamente "entende" os argumentos das mulheres que não desejam ser mães.

Esse é um ciclo perverso de perpetuação de desigualdades de participação e poder de decisão impostas às mulheres, e indiretamente às crianças, pela difusão de ideários como esse, pelas socializações, o que afeta a cidadania de ambas. Assim sendo, as disputas de forças e interesses distintos, iluminados pelos temas, dimensões e reflexões advindos da pesquisa teórica e dos encontros formativos apontam para a produção de territórios, pelas distintas vozes produzidas nas interlocuções analisadas, de modo objetivo e subjetivo. Ainda que tais vozes sejam conflitantes, em abordagens distintas, é justamente nesse vibrante debate que reside as condições de interpretação mais abrangentes, e justas, dos contextos vividos, e das sujeitas em questão, no caso, as mulheres e as crianças.

Democraticamente, é pelo debate que as vozes se fazem ouvir, em atividade de participação que resulta em transformação social. Logo, a creche, por acessar, de modo direto os debates sobre os direitos das crianças e dos direitos das mulheres, são territórios potentes a democratizar tais diálogos, pelo movimento dialógico, complementando e favorecendo construções contínuas, a todas as pessoas que interagem nesse ambiente. Um caminho possível, apontado pela perspectiva feminista - o qual a presente tese se propôs a explorar - é a conscientização política acerca das relações de maternagem. Na perspectiva dessa tese, a maternagem, se levada a termo, atuaria em criação de condições justas e qualitativas de corresponsabilidade com a Educação das crianças, incluindo o papel da Educação Infantil, o que corresponde ao direito das crianças em acessarem uma Educação de qualidade. Ao fomentar uma Educação de qualidade às crianças, as mulheres, em sendo fortalecidas, dentro 
e fora da Educação Infantil, faz-se justiça social e se respeitam os direitos delas. Compreendemos que uma Educação que compartilha as responsabilidades vem a tornar-se mais fraterna e mais democrática, o que reconstrói e reparte às infâncias um contexto mais digno e mais democrático para todas as pessoas, que é justamente o que pretende as formulações e conquistas dos Feminismos, e é o propósito de uma sociedade republicana, em que todas as pessoas deveriam ter o mesmo prestigio e reconhecimento social (PHILLIPS, 2011), mesmo com suas diferenças e conflitos.

Movidas por tais pressupostos, consideramos impossível não nos indignarmos perante uma Educação paternalista e assistencialista, que secundariza os modos de viver dos seres humanos em formação, e também em ressignificação, pelas constantes socializações e ressocializações advindas das transformações das sociedades, como pondera Mollo-Bouvier (2005).

Sendo assim, essa tese, ao tecer texto alinhavado com os variados fios das bandeiras de luta feministas, é um convite ao questionamento, a uma releitura política sobre a maternagem, pois se a igualdade formal, ou o acesso ao voto, a participação política, e a Educação, seguirem orientadas por relações de subserviência ou patronagem, a sociedade não será democrática. Pelo que foi apurado nos encontros formativos, há traços claros de que estamos em movimento, o que nos dá esperança, mesmo diante de desafio complexo de reaprender constantemente e nos reinventar cotidianamente. 


\section{REFERÊNCIAS BIBLIOGRÁFICAS:}

ALVES, Alesandra Maia Lima. A trajetória das políticas públicas de educação infantil no município de Juiz de Fora no período de 1996 a 2013. Juiz de Fora, 2016. Tese (Programa de Pós Graduação em Educação) Universidade Federal de Juiz de Fora.

APPLE, Michael. Ideologia e Currículo. São Paulo: Brasiliense, 1982.

ARAÚJO, Elisangela Alves de. "O escondido e o desenhado na Educação Infantil”. In:

Seminário Internacional fazendo gênero 10, 2013. Florianópolis. Anais. UFSC, 2013. p. 1-10. Disponível em:

www.fg2013.wwc2017.eventos.dype.com.br/.../anais/.../1373302707_ARQUIVO_Ar. Acesso em $02 / 03 / 2018$.

ARAÚJO, Vânia Carvalho de. O "tempo integral" na educação infantil: uma análise de suas concepções e práticas . In: Araújo, Vânia Carvalho de. Educação infantil em jornada de tempo integral : dilemas e perspectivas / [et al.].[Brasília, DF] : Ministério da Educação ; Vitória : EDUFES, 2015. p. 17-56.

ARROYO, Miguel. O direito a tempos-espaços de um justo e digno viver. In: MOLL, Jaqueline et al. Caminhos da educação integral no Brasil: direitos a outros tempos e espaços educativos. Porto Alegre; Penso, 2012. p. 33-45

AUAD, Daniela. Educar meninas e meninos: relações de gênero na escola. São Paulo: Contexto, 2006.

AUAD, Daniela. Feminismo: que história é essa? Rio de Janeiro: DP\&A, 2003.

AUAD, Daniela. Relações de gênero nas práticas escolares: da escola mista ao ideal de coeducação. São Paulo: FEUSP, FAPESP, Tese de Doutorado, 2004.

BADINTER, Elisabeth. O conflito: a Mulher e a Mãe. São Paulo: Record, 2011.

BADINTER, Elisabeth. Um Amor conquistado: o mito do amor materno. Rio de Janeiro: Nova Fronteira, 1985.

BENEVIDES, Maria Victoria de Mesquita. Cidadania e democracia. Lua Nova, São Paulo, n. 33, p. 5-16, agosto de 1994. Disponível em:

http://www.scielo.br/scielo.php?script=sci_arttext\&pid=S0102-

664451994000200002\&lng=en\&nrm=iso. Acesso em 19/04/2019

BENEVIDES, Maria Victoria de Mesquita. Educação para a democracia. Lua Nova, São Paulo, n. 38, p. 223-237, Dez. 1996. Disponível em http://www.scielo.br/scielo.php?script=sci_arttext\&pid=S0102$64451996000200011 \& \operatorname{lng}=$ en\&nrm=iso Acesso em 17/04/2019

BRANDÃO, Carlos Rodrigues. O outro ao meu lado: algumas ideias de tempos remotos e atuais para pensar a partilha do saber e a educação de hoje. In: MOLL, Jaqueline et al. 
Caminhos da educação integral no Brasil: direitos a outros tempos e espaços educativos. Porto Alegre; Penso, 2012.P. 46-71

BRASIL. Constituição da República Federativa do Brasil. Brasília; Senado Federal,1988. Disponível em www.planalto.gov.br/ccivil_03/constituicao/constituicaocompilado.htm Acesso em 31/03/2018

BRASIL. Lei no 8.069, de 13/07/1990. Dispõe sobre o Estatuto da Criança e do Adolescente e dá outras providências. Disponível em www.planalto.gov.br/ccivil_03/leis/18069.htm Acesso em 31/03/18.

BUCAS-FRANÇAIS, Anne. PENIT-SORIA Jacqueline, SAVEY, Nicole. Petite enfance et émancipation des femmes: pour la refondation du service public. Disponível em hussonet.free.fr/petitenf.pdf Acesso em 12/12/2018.

BURMAN, Erica. Desenvolvimento desejado? Contribuições psicanalíticas para o antidesenvolvimento psicológico. A peste. São Paulo, v. 1, n. 2, p. 269-294, jul./dez. 2009.

CAMPOS, Roselane Fatima. "Política pequena" para as crianças pequenas?: Experiências e desafios no atendimento das crianças de 0 a 3 anos na América Latina. Rev. Bras. Educ., Rio de Janeiro, v. 17, n. 49, p. 81-105, 2012 . Disponível em http://www.scielo.br/scielo.php?script=sci arttext\&pid=S1413$24782012000100005 \& \operatorname{lng}=\mathrm{en} \& \mathrm{nrm}=$ iso Acesso em 11/02/2019.

CAMINERO, Daniane Fatima Quadrado. BALDALOTTI, Rosana Maria. Concepções e práticas sobre a infância em instituições de educação infantil no município de Chapecó (SC). In: In: SEMINÁRIO INTERNACIONAL FAZENDO GÊNERO 10, 2013. Florianópolis. Anais. Florianópolis: UFSC, 2013. p. 1-12. Disponível em www.fg2013.wwc2017.eventos.dype.com.br/../1373337452_ARQUIVO_artigofazen.. Acesso Em 24/11/2017.

CANAVIEIRA, Fabiana Oliveira. PALMEN, Sueli Helena de Camargo. Movimentos sociais e a luta pela educação infantil. In: Infância e movimentos sociais. Vários/as autores/as. Campinas/SP: Edições Leitura Crítica, 2015. p.33-50

CARVALHO, Rodrigo Saballa de. VARGAS, Juliana Ribeiro de. Análises dos discursos de materiais formadores de docentes da Educação Infantil em termos de normatização como "professora exemplar". In: SEMINÁRIO INTERNACIONAL FAZENDO GÊNERO 10, 2013. Florianópolis. Anais. Florianópolis: UFSC, 2013. p. 1-12. Disponível em www.fg2013.wwc2017.eventos.dype.com.br/../1372714450_ARQUIVO_AGENERI... Acesso em 15/05/2018.

CHODOROW, Nancy. Psicanálise da Maternidade - Uma crítica a Freud a partir da Mulher. Rio de Janeiro: Rosa dos Tempos, 1990.

COLLIN, Françoise. LABORIE, Françoise. Maternidade. In. Dicionário Crítico do Feminismo. São Paulo, Editora UNESP, 2009. P.133-137.

COSTA, Fernanda C. Garcia. Educação Infantil de Juiz de Fora (MG): o processo de transferência da administração das creches da assistência social para a educação. Juiz de Fora, 
2006. Dissertação (Programa de Pós Graduação em Educação) Universidade Federal de Juiz de Fora.

DADOORIAN, Diana. Gravidez na adolescência: um novo olhar. Psicol cienc. prof. Brasília, v. 23, n. 1, p. 84-91, março de 2003. Disponível em

http://www.scielo.br/scielo.php?script=sci_arttext\&pid=S1414-

98932003000100012\&lng=en\&nrm=iso Acesso em 19/04/2019.

DAMICO, José, KLEIN, Carin.O uso da etnografia pós moderna para a investigação de políticas públicas de inclusão social. In: MEYER, Dagmar E. PARAÍSO, Marlucy Alves. Metodologias de pesquisas pós críticas em educação. Belo Horizonte; Mazza Edições, 2012. P. 63-85.

DEVREUX, Anne - Marie. A teoria das relações sociais de sexo: um quadro de análise sobre a dominação masculina. In: Cadernos de Crítica Feminista. 2011, nº4, p.6-29

EKENA. Todxs Putxs. São Carlos, SP. The Orchard Music, 2017. Disponível em https://www.youtube.com/watch?v=tVK1tlhIIUE. Acesso em 19/04/2021.

FAUR, Eleonor. El cuidado infantil em el siglo XXI: Mujeres malabaristas em uma sociedade desigual. Buenos Aires: Siglo Veintiuno Editores,2014.

FALUDI, Susan. Backlash: o contra-ataque na guerra não declarada contra as mulheres. São Paulo: Ed.Rocco, 2001.

FELIPE, Jane. Infância, gênero e sexualidade. Revista Educação e Realidade. $n^{0}$ 25, vol.1; jan/jun 2000. P.115-131.

FELIPE, Jane. Ministério da Educação. Secretaria de educação à Distância. Salto para o

Futuro: Educação para a Igualdade de Gênero. Ano XVIII - Boletim 26 - Novembro de 2008. Disponível em

http://www.educadores.diaadia.pr.gov.br/arquivos/File/cadernos_tematicos/salto_futuro_educ acao_igualdade_genero.pdf. Acesso em 19/04/2019.

FELIPE, Jane. Scripts de gênero, sexualidade e infâncias: temas para pensar a formação docente. In: ALBUQUERQUE, Simone Santos de. FELIPE, Jane. CORSO, Luciana Vellino. Para pensar a docência na Educação Infantil. Porto Alegre; Editora Vangraf, 2019. P.238250.

Disponível em https://pt.calameo.com/read/005858051b25d34ddb933 Acesso em 04/04/2019.

FERREIRA, Luiz Antonio Miguel. O Estatuto da Criança e do Adolescente e o professor: reflexos na sua formação e atuação. São Paulo: Ed. Cortez, 2010.

FONSECA, Cláudia. Ser mulher, mãe e pobre. In: Priori, Mary Del. História das Mulheres no Brasil. São Paulo: Contexto, 2000.

FREIRE, Paulo. Pedagogia do oprimido. Rio de Janeiro; Paz e Terra, 1987.

GIL, Antonio Carlos. Métodos e técnicas de pesquisa social. São Paulo; Editora Atlas, 2008. 
GUIMARÃES, Nadya Araujo. Casa e mercado, amor e trabalho, natureza e profissão: controvérsias sobre o processo de mercantilização do trabalho de cuidado. Cadernos Pagu. Vol. 46, janeiro-abril de 2016. P. 59-77. Disponível em http://www.scielo.br/scielo.php?script=sci_issuetoc\&pid=0104$833320160001 \& \operatorname{lng}=$ pt\&nrm=iso Acesso em 07/02/2019.

HAESBAERT, Rogério. O mito da desterritorialização: do "fim dos territórios" a multi-territorialidade. Rio de Janeiro: Bertrand Brasil, 2004.

HAESBAERT, Rogério. Território e multiterritorialidade: um debate. Revista GEOgraphia. Ano IX; n 17, 2007. P. 19-46.

HIRATA, Helena. GUIMARÃES, Nadya Araújo. Cuidado e Cuidadoras - as várias faces do care. São Paulo; Atlas, 2012.

HIRATA, Helena. O trabalho de cuidado - comparando Brasil Bélgica e Japão. Revista Ensaios. v.13 .n.24 , P. 53 - 64, 2016.

HOOKS, bel. Ensinando a transgredir: a educação como prática de liberdade. São Paulo; Ed. Martins Fontes, 2013.

KRAMER, Sônia. Com a pré-escola nas mãos: uma alternativa curricular para a educação infantil. São Paulo; Ática, 1989.

KUHLMANN JUNIOR, Moysés. Infância e educação infantil: uma abordagem histórica. Porto Alegre: Mediação, 1998.

JAGGAR, Alison M. Mulheres e cuidados: o que as feministas podem aprender sobre a moralidade a partir disso? In: JAGGAR, Alison M.; BORDO, Susan R. Gênero, Corpo, Conhecimento. Rio de Janeiro, Record, Rosa dos Tempos, 1997.

JUIZ DE FORA. Catálogo Social. Subsecretaria de Vigilância e Monitoramento de Assistência Social. Juiz de Fora (MG): Funalfa, 2012. Disponível em https://www.pjf.mg.gov.br/secretarias/sds/arquivos/publicacoes/catalogo_social.pdf Acesso em $09 / 12 / 2018$.

LIMA, Claudinei dos Santos. Os Significados do Conselho Tutelar como um Dispositivo de Governo de Crianças e Adolescentes. Juiz de Fora, 2014. Dissertação (Programa de Pós Graduação em Ciências Sociais) Universidade Federal de Juiz de Fora.

LOURO, Guacira. Gênero, sexualidade e educação. Uma perspectiva pós estruturalista. Petrópolis, RJ. Vozes, 1997.

LONGO, Isis. Ser criança e adolescente na sociedade brasileira: passado e presente da história dos direitos infanto juvenis. S/d. P. 1-20.Disponível em http://www.proceedings.scielo.br/pdf/cips/n3/n3a13.pdf Acesso em 19/05/2018.

LOPES, Jader Janer Moreira. Geografia das Crianças, Geografias das Infâncias: as contribuições da Geografia para os estudos das crianças e suas infâncias. Contexto \& Educação; Ed. Unijuí, nº 79, Ano 23. Jan/Jun.2008, P.65-82. 
MACHADO, Girlane Martins. COUTINHO, Karyne Dias. Reflexões sobre a idealização da imagem da criança e da professora associadas ao gênero. In: SEMINÁRIO ENLAÇANDO SEXUALIDADES 2015. Anais IV Seminário Enlaçando Sexualidades 2015. Disponível em www.uneb.br/enlacandosexualidade/2015/ 07/08/anais-IV-seminario-enlacandosexualidade-2015/ acesso em 04/04/2018.

MARQUES-PEREIRA, Bérengére. Cidadania. In: Dicionário Crítico do Feminismo. São Paulo, Editora UNESP, 2009. P.35-39.

MARTINS, Kátia Batista . LIMA, Andrêsa Helena de. LIMA, Luciene Aparecida Silva Sexualidade e gênero na construção das subjetividades: um olhar para a educação infantil. In: SEMINÁRIO INTERNACIONAL FAZENDO GÊNERO 10, 2013. Florianópolis. Anais. Florianópolis: UFSC, 2013. p. 1-10. Disponível em www.fg2013.wwc2017.eventos.dype.com.br/../1373288836_ARQUIVO_SEXUALI... Acesso em 20/04/2017.

MACKINNON, Catherine A. Feminismo, Marxismo, Método e o Estado: Uma agenda Para Teoria. Revista Direito e Práxis. Rio de Janeiro, Vol. 07, N.15,2016, p.798-837

MEYER, Dagmar E. Uma politização contemporânea da maternidade: construindo um argumento. Revista Gênero. Vol.6; nº 1,2005.

MOLL, Jaqueline. A agenda da educação integral : compromissos para sua consolidação como política pública. In: MOLL, Jaqueline et al. Caminhos da educação integral no Brasil: direitos a outros tempos e espaços educativos. Porto Alegre; Penso, 2012. P. 129-148.

MOLLO- BOUVIER, Suzanne. Transformações nos modos de socialização das crianças: uma abordagem sociológica. Ver. Educ. Soc. Campinas, vol.26, n.91, p 391-403, 2005.

NUNES, Maria Fernanda Rezende; CORSINO, Patrícia; DIDONET, Vital.

Educação infantil no Brasil: primeira etapa da educação básica.Unesco, Ministério da Educação/Secretaria de Educação Básica, Brasília, Fundação Orsa, 2011

OLIVEIRA, Zilma Ramos de. O trabalho do professor na Educação Infantil. São Paulo; Biruta, 2012.

PASINATO, Luana. MOSMANN, Clarice. Transição para a parentalidade e a coparentalidade: casais que os filhos ingressaram na escola ao término da licençamaternidade. Avances en Psicología Latinoamericana, 34(1), 2016, P. 129-142.

PAUTASSI, Laura. Há igualdade na desigualdade? Abrangência e limites das ações afirmativas. Revista Internacional de Direitos Humanos. Número 6, p. 70- 94, 2007.

PINTO, Céli Regina Jardim. Uma história do feminismo no Brasil. São Paulo; Editora Perseu Abramo, 2003.

PENA, Erica Dumont. Cuidar: relações sociais, práticas e sentidos no contexto da Educação Infantil. Belo Horizonte, 2015, Tese. Universidade Federal de Minas Gerais. Disponível em www.bibliotecadigital.ufmg.br/dspace/handle/1843/BUBD-A4CF73 Acesso em 28/07/2018 
PHILLIPS, Anne. O que há de errado com uma democracia liberal ?. Rev.

Bras. Ciênc. Polít. , Brasília, n. 6, pág. 339-363, dezembro de 2011. Disponível em $\mathrm{http}: / / \mathrm{www}$.scielo.br/scielo.php?script=sci arttext\&pid=S0103-

$33522011000200013 \& \operatorname{lng}=$ en\&nrm=iso Acesso em 06/02/20.

RAMOS, Maria Rita Neves. Relações de gênero e docência na Educação Infantil: interfaces entre políticas públicas e abordagens pedagógicas. Juiz de Fora, 2016. Dissertação (Programa de Pós Graduação em Educação) Universidade Federal de Juiz de Fora.

REZENDE, Marilúcia Antônia de. MACHADO, Ilze Maria Coelho. Educação Infantil no período noturno: a prática pedagógica em contexto de vulnerabilidade social. 2012.P.1-16. Disponível em http://www.anped.org.br/sites/default/files/gt07-2037_int.pdf Acesso em 09/07/2018.

RICH, Adrienne. Heterossexualidade compulsória e existência lésbica. Bagoas - Estudos gays: gêneros e sexualidades, v. 4, n. 05, 27 nov. 2012.Disponível em https://periodicos.ufrn.br/bagoas/article/view/2309/1742 Acesso em 08/06/2020.

ROSA, Cristiano Eduardo da; FELIPE, Jane. Uma Diva Dentro de Mim: descobertas femininas sobre scripts de gênero no processo de montação drag queen. In: RIBEIRO, Joyce Otânia Seixas; VILAÇA, Teresa; BRÍCIO, Vilma Nonato; MENDES, Sandra Karina Barbosa (Orgs.). Gênero, Sexualidade e Educação: problemas contemporâneos. Curitiba: CRV, 2019. p. 61-75.

ROSEMBERG, Fúlvia. O movimento de mulheres e abertura política no Brasil: o caso das creches. Cadernos de Pesquisa; São Paulo, vol.51, p.73-79, 1984.

SAFFIOTI, Heleieth Iara Bongiovani. Gênero, patriarcado, violência. São Paulo: Editora Fundação Perseu Abramo, 2011.

SCAVONE, Lucila. A maternidade e o feminismo: diálogo com as ciências sociais. Cadernos Pagu [online]. 2001, n. 16, pp. 137-150. Disponível em:

https://www.scielo.br/j/cpa/a/3wSKqcsySs8ZV4rHM63K8Lz/?lang=pt\# Acesso em $18 / 09 / 2020$.

SCOTT, Joan Wallach. A Mulher Trabalhadora. In: História das Mulheres no Ocidente. DUBY, George. PERROT, Michelle. São Paulo: Edições Afrontamento,1994. Disponível em https://pt.scribd.com/document/112492214/Texto-de-Joan-Scott-A-Mulher-Trabalhadora Acesso em 31/03/18.

SCOTT, Joan Wallach. Gênero: uma categoria útil de análise histórica. Educação e Realidade. Porto Alegre, vol. 20, no 2, jul/dez.1995, p.77-99.

SILVA, Fernanda Bichara da. Diversidade e educação: do slogan à intersecção das categorias sociais. Juiz de Fora, 2013. Dissertação (Programa de Pós Graduação em Educação) Universidade Federal de Juiz de Fora.

SILVA, Tânia Maria Gomes da. Mulheres, maternidade e identidade de gênero. In: SEMINÁRIO INTERNACIONAL FAZENDO GÊNERO 10, 2013. Florianópolis. Anais. 
Florianópolis: UFSC, 2013. p.1-12.Disponível em http://www.fg2013.wwc2017.eventos.dype.com.br/resources/anais/20/1371640271_ARQUIV O_Mulheres,maternidadeeidentidadedegenero.pdf Acesso em 09/01/2021. Acesso em $08 / 09 / 2018$

SCHWENGBER, Maria Simone Vione. MEYER, Dagmar Estermann. Discursos que (con)formam corpos grávidos: da medicina à educação física. Cad. Pagu [online]. 2011, n.36.

SORJ, Bila. Socialização do cuidado e desigualdades sociais. Tempo soc., São Paulo,v. 26, n. 1, p. 123-128, 2014. Disponível em http://www.scielo.br/scielo.php?script=sci_arttext\&pid=S0103$20702014000100009 \& \operatorname{lng}=$ en\&nrm $=$ iso

SOUZA, Raquel Santiago. Família e escola: estudos de uma relação (in)delicada a partir das relações de gênero. Juiz de Fora, 2017. Dissertação (Programa de Pós Graduação em Educação) Universidade Federal de Juiz de Fora.

STERNBACH, Nancy Saporta. ARANGUREN, Marysa Navarro. CHUCHRYK, Patricia. ALVAREZ Sonia E. Feministas na América Latina: de Bogotá a San Bernardo. Estudos Feministas. $\mathrm{N}^{\text {o }}$ 2, p. 255-295, 1994

TARDIF, Maurice. Saberes docentes e saber profissional. Petrópolis; Rio de Janeiro, Ed. Vozes, 2002.

TELES, Maria Amélia de Almeida. A participação feminina na luta por creches! In: Infância e movimentos sociais. Vários/as autores/as. - Campinas/SP: Edições Leitura Crítica, 2015, p,21-34.

TELES, Maria Amélia de Almeida. Feminismo no Brasil: trajetória e perspectivas. In: Sociedade de Teologia e Ciências da Religião. Gênero e Teologia - interpelações e perspectivas. Belo Horizonte: Edições Loyola, 2003.

THURLER, Ana Liési. Primeira infância no Brasil do século XXI: desafios ao reconhecimento institucional. In: BASTOS, Eliene Ferreira. ASSIS, Arnoldo Camanho de. SANTOS, Marlouve Moreno Sampaio. Família e Jurisdição III. Belo Horizonte: Editora Del Rey, 2009. p.1-34.

VIEIRA, Regina Stela Corrêa. Mulher, Trabalho e Maternidade: análise do sexismo presente no direito do trabalho brasileiro como barreira à igualdade de gênero. In: SEMINÁRIO INTERNACIONAL FAZENDO GÊNERO 10, 2013. Florianópolis. Anais. Florianópolis: UFSC, 2013. p. 1-12. Disponível em http://www.fg2013.wwc2017.eventos.dype.com.br/resources/anais/20/1373336689_ARQUIV O_Trabalhocompleto_ReginaStelaCorreaVieira.pdf Acesso em 01/04/2018.

ZANETTI, Alexsandra. O processo de transição das creches da Assistência Social para a Educação Infantil em Juiz de Fora (MG)(2008-2013). Juiz de Fora, 2015. Tese (Programa de Pós Graduação em Educação) Universidade do Estado do Rio de Janeiro. 


\section{APÊNDICES E ANEXOS}

\section{APÊNDICE 1:}

TERMO DE CONSENTIMENTO LIVRE E ESCLARECIDO

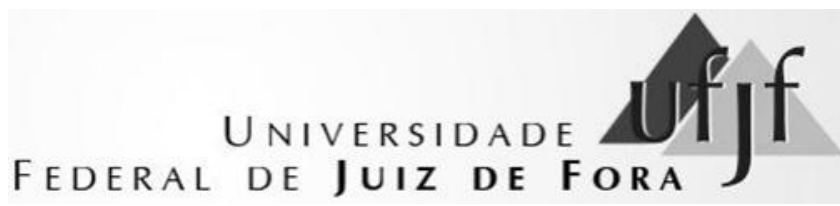

\section{TERMO DE CONSENTIMENTO LIVRE E ESCLARECIDO}

Gostaríamos de convidar você a participar como voluntário (a) da pesquisa "Educação Infantil em perspectiva feminista: maternagens e cuidado como desejo de democracia". O motivo que nos leva a realizar esta pesquisa é estudar sobre o compartilhamento das responsabilidades com a Educação das crianças com outras pessoas além da mãe e pensar numa Educação em que as crianças sejam educadas com menos desigualdade entre os sexos.

Nesta pesquisa pretendemos conhecer como a creche se reconhece como espaço de direitos das crianças e das mulheres. Caso você concorde em participar, vamos fazer as seguintes atividades com você: serão feitas conversas em grupo sobre o tema da pesquisa, em que serão apresentados vídeos e textos para auxiliar nas discussões. Esta pesquisa tem alguns riscos, como a de você não se identificar com o tema das conversas ou alguém identificar sua participação na pesquisa. Mas para diminuir a chance desses riscos acontecerem, utilizaremos pseudônimos quando a pesquisa mencionar as falas das conversas em grupo. A qualquer momento, você poderá cancelar a sua participação nas conversas em grupo. A pesquisa pode ajudar a sociedade como um todo a pensar sobre uma Educação mais igualitária desde a infância.

Para participar deste estudo você não vai ter nenhum custo nem receberá qualquer vantagem financeira. Apesar disso, se você tiver algum dano por causadas atividades que fizermos com você nesta pesquisa, você tem direito a indenização. Você terá todas as informações que quiser sobre esta pesquisa e estará livre para participar ou recusar-se a participar. Mesmo que você queira participar agora, você pode voltar atrás ou parar de participar a qualquer momento. A sua participação é voluntária e o fato de não querer participar não vai trazer qualquer penalidade ou mudança na forma em que você é atendida. A pesquisadora não vai divulgar seu nome. Os resultados da pesquisa estarão à sua disposição quando finalizada. Seu nome ou o material que indique sua participação não será liberado sem a sua permissão. Você não será identificado (a) em nenhuma publicação que possa resultar 
dessa pesquisa. Este termo de consentimento encontra-se impresso em duas vias originais, sendo que uma será arquivada pela pesquisadora responsável e a outra será fornecida a você. Os dados coletados na pesquisa ficarão arquivados com a pesquisadora responsável por um período de 5 (cinco) anos, e após esse tempo serão destruídos. Os pesquisadores tratarão a sua identidade com padrões profissionais de sigilo, atendendo a legislação brasileira (Resolução No 466/12 do Conselho Nacional de Saúde), utilizando as informações somente para os fins acadêmicos e científicos.

Declaro que concordo em participar da pesquisa e que me foi dada à oportunidade de ler e esclarecer as minhas dúvidas.

Juiz de Fora, de de 20 .

Assinatura da Participante

Assinatura da Pesquisadora

Nome da Pesquisadora Responsável: Maria Rita Neves Ramos

Campus Universitário da UFJF

Faculdade/Departamento/Instituto: Programa de Pós Graduação em Educação (PPGE) Faculdade de Educação.

CEP: $36036-900$

Fone: (32) 3222-2577/ (32)98834-6741

PPGE: (32) 2102-3665

E-mail: nevesramosm@yahoo.com.br

PPGE: ppge@ufjf.edu.br 
APÊNDICE 2:

QUANTITATIVO GERAL - PESQUISA BIBLIOGRÁFICA

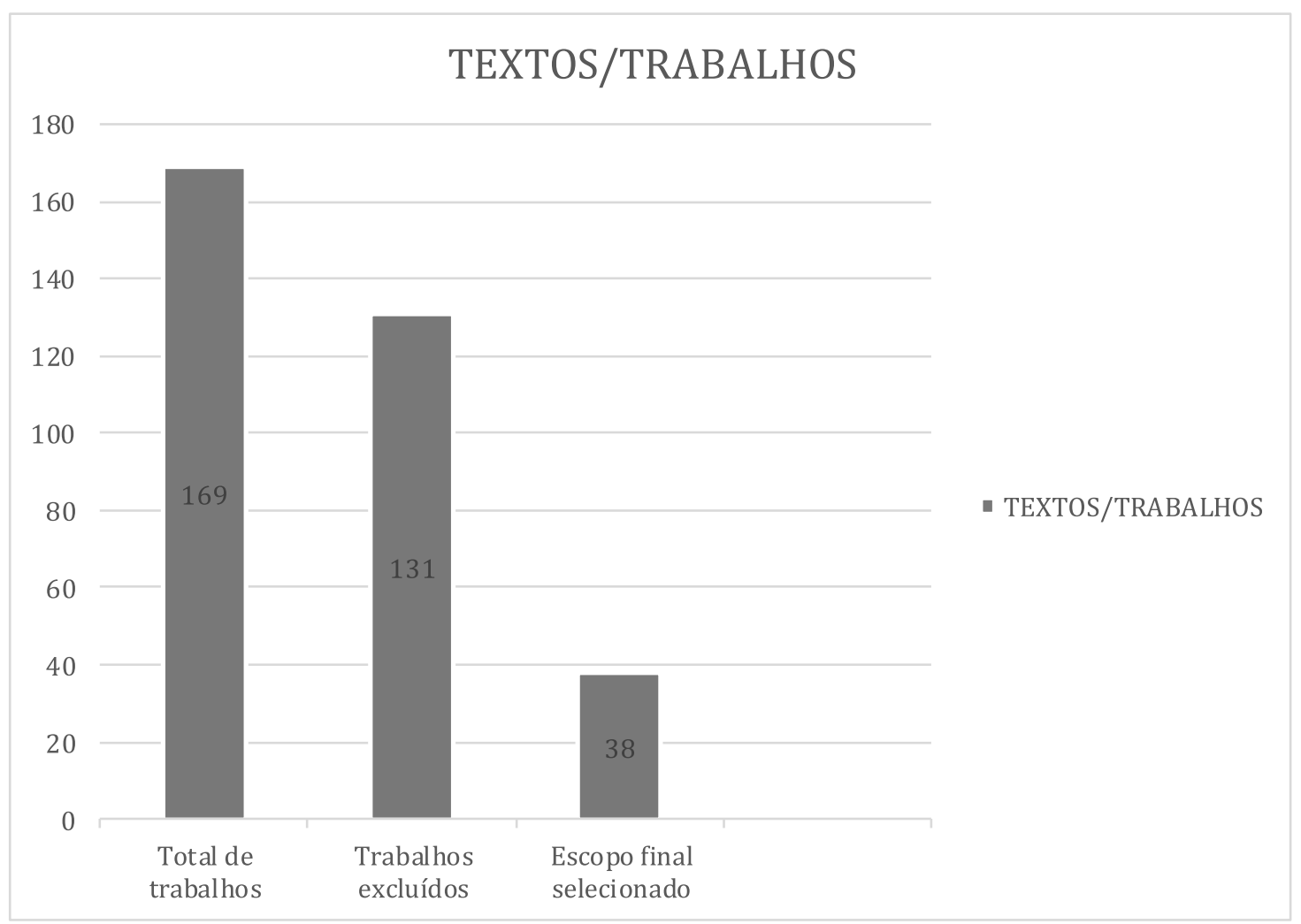




\section{APÊNDICE 2:}

\section{TRABALHOS SELECIONADOS - PESQUISA BIBLIOGRÁFICA}

\begin{tabular}{|c|c|c|c|c|c|c|}
\hline Título & Autor@s & Assunto & Área & Fonte & Ano & Tipo \\
\hline $\begin{array}{l}\text { 1-Sexualidade e } \\
\text { gênero na } \\
\text { construção das } \\
\text { subjetividades: } \\
\text { um olhar para a } \\
\text { educação infantil }\end{array}$ & $\begin{array}{l}\text { Kátia Batista } \\
\text { Martins, } \\
\text { Andressa } \\
\text { Helena de } \\
\text { Lima e } \\
\text { Luciene } \\
\text { Aparecida } \\
\text { Silva }\end{array}$ & $\begin{array}{l}\text { Investigação } \\
\text { sobre os } \\
\text { princípios ético e } \\
\text { políticos } \\
\text { envolvidos na } \\
\text { abordagem das } \\
\text { diferenças. }\end{array}$ & $\begin{array}{l}\text { Edu } \\
\text { cação }\end{array}$ & $\begin{array}{l}\text { Fazendo } \\
\text { Gênero } \\
10\end{array}$ & 2013 & Artigo \\
\hline $\begin{array}{l}\text { 2-Concepções e } \\
\text { práticas sobre a } \\
\text { infância em } \\
\text { instituições de } \\
\text { educação infantil } \\
\text { no município de } \\
\text { Chapecó (SC) }\end{array}$ & $\begin{array}{l}\text { Daniane } \\
\text { Fatima } \\
\text { Quadrado } \\
\text { Caminero, } \\
\text { Rosana Maria } \\
\text { Badalotti }\end{array}$ & $\begin{array}{l}\text { Discussão sobre } \\
\text { as concepções de } \\
\text { infância e suas } \\
\text { reflexões } \\
\text { contemporâneas. }\end{array}$ & Educação & $\begin{array}{l}\text { Fazendo } \\
\text { Gênero } \\
10\end{array}$ & 2013 & Artigo \\
\hline $\begin{array}{l}\text { 3- O escondido e } \\
\text { o desenhado nos } \\
\text { bastidores da } \\
\text { educação infantil }\end{array}$ & $\begin{array}{l}\text { Elisangela } \\
\text { Alves de } \\
\text { Araújo }\end{array}$ & $\begin{array}{l}\text { Relações de } \\
\text { gênero e } \\
\text { sexualidade na } \\
\text { educação infantil } \\
\text { na visão de } \\
\text { crianças, famílias } \\
\text { e educadores }\end{array}$ & $\begin{array}{l}\text { Ciências } \\
\text { Humanas }\end{array}$ & $\begin{array}{l}\text { Fazendo } \\
\text { Gênero } \\
10\end{array}$ & 2013 & Artigo \\
\hline $\begin{array}{l}\text { 4- A produção } \\
\text { científica sobre o } \\
\text { brincar entre } \\
\text { meninos e } \\
\text { meninas na } \\
\text { Educação } \\
\text { Infantil: } \\
\text { rompendo } \\
\text { fronteiras de } \\
\text { gênero }\end{array}$ & $\begin{array}{l}\text { Heliany } \\
\text { Pereira dos } \\
\text { Santos, Altina } \\
\text { Abadia da } \\
\text { Silva }\end{array}$ & $\begin{array}{l}\text { Discussão sobre } \\
\text { as produções } \\
\text { científicas que } \\
\text { explanam sobre a } \\
\text { interface com a } \\
\text { questão do gênero }\end{array}$ & Educação & $\begin{array}{l}\text { Fazendo } \\
\text { Gênero } \\
10\end{array}$ & 2013 & Artigo \\
\hline $\begin{array}{l}5 \text { - A } \\
\text { generificação da } \\
\text { docência na } \\
\text { Educação } \\
\text { Infantil: } \\
\text { problematizando } \\
\text { discursos } \\
\text { presentes em } \\
\text { livros de } \\
\text { formação de } \\
\text { professores }\end{array}$ & $\begin{array}{l}\text { Rodrigo } \\
\text { Saballa de } \\
\text { Carvalho, } \\
\text { Juliana Ribeiro } \\
\text { de Vargas }\end{array}$ & $\begin{array}{l}\text { Análise dos } \\
\text { discursos de } \\
\text { materiais } \\
\text { formadores de } \\
\text { docentes da } \\
\text { Educação Infantil } \\
\text { em termos de } \\
\text { normatização } \\
\text { como "professora } \\
\text { exemplar". }\end{array}$ & Educação & $\begin{array}{l}\text { Fazendo } \\
\text { Gênero } \\
10\end{array}$ & 2013 & Artigo \\
\hline
\end{tabular}




\begin{tabular}{|c|c|c|c|c|c|c|}
\hline Título & Autor@s & Assunto & Área & Fonte & Ano & Tipo \\
\hline $\begin{array}{l}\text { 6- Relações de } \\
\text { gênero como } \\
\text { possibilidade e } \\
\text { como limite de } \\
\text { ação social num } \\
\text { contexto de } \\
\text { educação infantil }\end{array}$ & $\begin{array}{l}\text { Márcia Buss- } \\
\text { Simão }\end{array}$ & $\begin{array}{l}\text { Investigação } \\
\text { sobre as maneiras } \\
\text { que as crianças } \\
\text { aprendem sobre o } \\
\text { gênero. }\end{array}$ & Educação & $\begin{array}{l}\text { Fazendo } \\
\text { Gênero } \\
10\end{array}$ & 2013 & Artigo \\
\hline $\begin{array}{l}7 \text { - O que é ser } \\
\text { menino e o que é } \\
\text { ser menina na } \\
\text { Educação } \\
\text { Infantil? Um } \\
\text { olhar etnográfico }\end{array}$ & $\begin{array}{l}\text { Abraão Felipe } \\
\text { Santos de } \\
\text { Oliveira }\end{array}$ & $\begin{array}{l}\text { Influências das } \\
\text { construções } \\
\text { sociais na } \\
\text { operacionalização } \\
\text { das relações das } \\
\text { crianças no } \\
\text { ambiente escolar. }\end{array}$ & Educação & $\begin{array}{l}\text { Desfazen } \\
\text { do } \\
\text { Gênero }\end{array}$ & 2013 & Artigo \\
\hline $\begin{array}{l}\text { 8- } \\
\text { Problematizando } \\
\text { estereótipos de } \\
\text { gênero na } \\
\text { educação infantil }\end{array}$ & $\begin{array}{l}\text { Girlane } \\
\text { Martins } \\
\text { Machado, } \\
\text { Karyne Dias } \\
\text { Coutinho }\end{array}$ & $\begin{array}{l}\text { Reflexões sobre a } \\
\text { idealização da } \\
\text { imagem da } \\
\text { criança e da } \\
\text { professora } \\
\text { associadas ao } \\
\text { gênero. }\end{array}$ & Educação & $\begin{array}{l}\text { Enlaçand } \\
\text { o } \\
\text { Sexualida } \\
\text { des }\end{array}$ & 2015 & Artigo \\
\hline $\begin{array}{l}\text { 9- } \\
\text { Heteronormativid } \\
\text { ade e educação } \\
\text { infantil: as } \\
\text { marcas } \\
\text { generificadas/dor } \\
\text { as do trabalho } \\
\text { docente a partir } \\
\text { dos enunciados } \\
\text { presentes nos } \\
\text { documentos } \\
\text { regulamentadores } \\
\text { da área }\end{array}$ & $\begin{array}{l}\text { Francisco } \\
\text { Ullissis Paixão } \\
\text { e Vasconcelos, } \\
\text { Fernando } \\
\text { Altair Pocahy }\end{array}$ & $\begin{array}{l}\text { Analisa como as } \\
\text { políticas públicas } \\
\text { endossam uma } \\
\text { lógica } \\
\text { heteronormativa } \\
\text { em que } \\
\text { predomina a } \\
\text { presença feminina } \\
\text { na docência da } \\
\text { educação infantil }\end{array}$ & Educação & $\begin{array}{l}\text { Enlaçand } \\
\text { o } \\
\text { Sexualida } \\
\text { des }\end{array}$ & 2015 & Artigo \\
\hline $\begin{array}{l}\text { 10- Orientação } \\
\text { sexual na } \\
\text { educação infantil } \\
\text { como estratégia } \\
\text { de gestão escolar: } \\
\text { manifestações da } \\
\text { sexualidade - um } \\
\text { desafio para pais } \\
\text { e educadores nas } \\
\text { escolas públicas } \\
\text { municipais de } \\
\text { Jequié-BA }\end{array}$ & $\begin{array}{l}\text { Mac Cleide de } \\
\text { Jesus Braga } \\
\text { Amaral, } \\
\text { Elane Braga } \\
\text { Oliveira }\end{array}$ & $\begin{array}{l}\text { Sexualidade como } \\
\text { desafio para a } \\
\text { gestão escolar. }\end{array}$ & Educação & $\begin{array}{l}\text { Enlaçand } \\
\text { o } \\
\text { sexualida } \\
\text { des }\end{array}$ & 2013 & Artigo \\
\hline $\begin{array}{l}11 \text { - Iniciativas } \\
\text { Populares: o } \\
\text { movimento } \\
\text { comunitário e a } \\
\text { educação infantil } \\
\end{array}$ & $\begin{array}{l}\text { Edson } \\
\text { Cordeiro dos } \\
\text { santos }\end{array}$ & $\begin{array}{l}\text { Histórico da } \\
\text { Educação infantil } \\
\text { comunitária } \\
\text { dialogando com o } \\
\text { cenário político }\end{array}$ & Educação & $\begin{array}{l}\text { Biblioteca } \\
\text { on line- } \\
\text { ANPED }\end{array}$ & 2015 & Artigo \\
\hline
\end{tabular}




\begin{tabular}{|c|c|c|c|c|c|c|}
\hline $\begin{array}{l}\text { na baixada } \\
\text { fluminense }\end{array}$ & & brasileiro & & & & \\
\hline Título & Autor@s & Assunto & Área & Fonte & Ano & Tipo \\
\hline $\begin{array}{l}\text { 12-“Caos calmo": } \\
\text { (in)constâncias } \\
\text { no cenário da } \\
\text { política de } \\
\text { educação infantil } \\
\text { brasileira }\end{array}$ & $\begin{array}{l}\text { Fabiana } \\
\text { Oliveira } \\
\text { Canavieira }\end{array}$ & $\begin{array}{l}\text { Relato da } \\
\text { construção } \\
\text { política e } \\
\text { epistemológica da } \\
\text { EI no período dos } \\
\text { dois governos do } \\
\text { presidente Lula }\end{array}$ & Educação & $\begin{array}{l}\text { Biblioteca } \\
\text { on line } \\
\text { ANPED }\end{array}$ & 2012 & Artigo \\
\hline $\begin{array}{l}\text { 13-A mediação } \\
\text { de uma } \\
\text { professora de } \\
\text { Educação infantil } \\
\text { nas brincadeiras } \\
\text { de faz de conta de } \\
\text { crianças } \\
\text { ribeirinhas }\end{array}$ & $\begin{array}{l}\text { Sônia Regina } \\
\text { dos Santos } \\
\text { Teixeira }\end{array}$ & $\begin{array}{l}\text { Estudo sobre o } \\
\text { papel da } \\
\text { mediação de uma } \\
\text { professora nas } \\
\text { brincadeiras de } \\
\text { crianças } \\
\text { ribeirinhas e o } \\
\text { contato destas } \\
\text { com as } \\
\text { construções } \\
\text { culturais desse } \\
\text { contexto } \\
\text { específico. }\end{array}$ & Educação & $\begin{array}{l}\text { Biblioteca } \\
\text { on line } \\
\text { ANPED }\end{array}$ & 2012 & Artigo \\
\hline $\begin{array}{l}14-\text { A } \\
\text { compreensão das } \\
\text { relações de } \\
\text { parentesco pelas } \\
\text { crianças na } \\
\text { brincadeira de faz } \\
\text { de conta em } \\
\text { contexto de } \\
\text { educação infantil }\end{array}$ & $\begin{array}{l}\text { Renata da } \\
\text { Costa Maynart } \\
\text {, Lenira } \\
\text { Haddad }\end{array}$ & $\begin{array}{l}\text { Observação de } \\
\text { situações de } \\
\text { brincadeiras que } \\
\text { revelaram que as } \\
\text { crianças trazem } \\
\text { suas } \\
\text { compreensões } \\
\text { sobre si e do outro } \\
\text { em termos de } \\
\text { relações de poder, } \\
\text { parentesco e } \\
\text { gênero. }\end{array}$ & Educação & $\begin{array}{l}\text { Biblioteca } \\
\text { on line } \\
\text { ANPED }\end{array}$ & 2012 & Artigo \\
\hline $\begin{array}{l}\text { 15-Educação } \\
\text { infantil no } \\
\text { período noturno: } \\
\text { a prática } \\
\text { pedagógica em } \\
\text { contexto de } \\
\text { vulnerabilidade } \\
\text { social }\end{array}$ & $\begin{array}{l}\text { Marilúcia } \\
\text { Antônia de } \\
\text { Resende, Ilze } \\
\text { Maria Coelho } \\
\text { Machado }\end{array}$ & $\begin{array}{l}\text { Analisa as } \\
\text { propostas } \\
\text { pedagógicas de } \\
\text { escola infantil que } \\
\text { funciona em } \\
\text { período noturno e } \\
\text { aponta as } \\
\text { expectativas que } \\
\text { se relacionam } \\
\text { com o contexto } \\
\text { social do público- } \\
\text { alvo. }\end{array}$ & Educação & $\begin{array}{l}\text { Biblioteca } \\
\text { on line } \\
\text { ANPED }\end{array}$ & 2012 & Artigo \\
\hline $\begin{array}{l}\text { 16- Inserção e } \\
\text { vivências } \\
\text { cotidianas: como } \\
\text { crianças } \\
\text { pequenas } \\
\text { experienciam sua } \\
\text { entrada na }\end{array}$ & $\begin{array}{l}\text { Lucilaine } \\
\text { Maria da Silva } \\
\text { Reis }\end{array}$ & $\begin{array}{l}\text { Estudo sobre a } \\
\text { inserção de } \\
\text { crianças de dois } \\
\text { anos em uma } \\
\text { escola de } \\
\text { educação infantil } \\
\text { de tempo integral. }\end{array}$ & Educação & $\begin{array}{l}\text { Biblioteca } \\
\text { on line } \\
\text { ANPED }\end{array}$ & 2013 & Artigo \\
\hline
\end{tabular}




\begin{tabular}{|c|c|c|c|c|c|c|}
\hline $\begin{array}{l}\text { educação } \\
\text { infantil? }\end{array}$ & & & & & & \\
\hline Título & Autor@s & Assunto & Área & Fonte & Ano & Tipo \\
\hline $\begin{array}{l}\text { 17-“Meu irmão } \\
\text { tem } 3 \text { anos e não } \\
\text { estuda porque ele } \\
\text { é criancinha" - o } \\
\text { que dizem as } \\
\text { crianças sobre a } \\
\text { educação infantil } \\
\text { e o direito? }\end{array}$ & $\begin{array}{l}\text { Leandro } \\
\text { Henrique de } \\
\text { Jesus Tavares }\end{array}$ & $\begin{array}{l}\text { Abordagem da } \\
\text { temática do } \\
\text { direito à } \\
\text { Educação sob a } \\
\text { ótica das crianças. }\end{array}$ & Educação & $\begin{array}{l}\text { Biblioteca } \\
\text { on line } \\
\text { ANPED }\end{array}$ & 2015 & Artigo \\
\hline $\begin{array}{l}\text { 18-A criança e } \\
\text { sua relação com a } \\
\text { sociedade: } \\
\text { considerações } \\
\text { sobre a } \\
\text { participação } \\
\text { infantil nos } \\
\text { espaços públicos }\end{array}$ & $\begin{array}{l}\text { Fabiana de } \\
\text { Oliveira }\end{array}$ & $\begin{array}{l}\text { Ensaio sobre as } \\
\text { transformações } \\
\text { acerca da } \\
\text { participação } \\
\text { infantil nos } \\
\text { modos de relação } \\
\text { até então } \\
\text { estabelecidos de } \\
\text { adultos e crianças. }\end{array}$ & Educação & $\begin{array}{l}\text { Biblioteca } \\
\text { on line } \\
\text { ANPED }\end{array}$ & 2015 & Artigo \\
\hline $\begin{array}{l}\text { 19-Mulher, } \\
\text { trabalho e } \\
\text { maternidade: } \\
\text { análise do } \\
\text { sexismo presente } \\
\text { no Direito do } \\
\text { Trabalho } \\
\text { brasileiro como } \\
\text { barreira à } \\
\text { igualdade de } \\
\text { gênero }\end{array}$ & $\begin{array}{l}\text { Regina Stela } \\
\text { Corrêa Vieira }\end{array}$ & $\begin{array}{l}\text { Estuda as } \\
\text { especificidades } \\
\text { das relações do } \\
\text { trabalho } \\
\text { produtivo e a } \\
\text { maternidade e o } \\
\text { papel da } \\
\text { legislação. }\end{array}$ & Direito & $\begin{array}{l}\text { Fazendo } \\
\text { Gênero } \\
10\end{array}$ & 2013 & Artigo \\
\hline $\begin{array}{l}\text { 20-Mulheres, } \\
\text { maternidade e } \\
\text { identidade de } \\
\text { gênero }\end{array}$ & $\begin{array}{l}\text { Tânia Maria } \\
\text { Gomes da } \\
\text { Silva }\end{array}$ & $\begin{array}{l}\text { Traz relatos de } \\
\text { vida que abordam } \\
\text { a maternidade e a } \\
\text { pobreza }\end{array}$ & História & $\begin{array}{l}\text { Fazendo } \\
\text { Gênero } \\
10\end{array}$ & 2013 & Artigo \\
\hline $\begin{array}{l}\text { 21-Familias } \\
\text { matriarcais, } \\
\text { maternidade e } \\
\text { lesbianidade }\end{array}$ & $\begin{array}{l}\text { Cibele da } \\
\text { Silva } \\
\text { Henriques }\end{array}$ & $\begin{array}{l}\text { Sistematização de } \\
\text { estudos sobre } \\
\text { maternagem de } \\
\text { mulheres lésbicas } \\
\end{array}$ & $\begin{array}{l}\text { Serviço } \\
\text { Social }\end{array}$ & $\begin{array}{l}\text { Enlaçand } \\
\text { o } \\
\text { Sexualida } \\
\text { des }\end{array}$ & 2015 & Artigo \\
\hline $\begin{array}{l}\text { 22- “Ter feito } \\
\text { aborto não me } \\
\text { tira o direito de } \\
\text { ser mãe': dilemas } \\
\text { relativos à } \\
\text { interrupção de } \\
\text { gravidez e o } \\
\text { exercício da } \\
\text { maternidade nos } \\
\text { discursos de } \\
\text { mulheres em uma } \\
\text { capital }\end{array}$ & $\begin{array}{l}\text { Cássia Helena } \\
\text { Dantas Sousa, } \\
\text { Rozeli Maria } \\
\text { Porto }\end{array}$ & $\begin{array}{l}\text { Reflexão sobre os } \\
\text { discursos sobre } \\
\text { aborto e } \\
\text { maternidade. }\end{array}$ & $\begin{array}{l}\text { Antropolo } \\
\text { gia }\end{array}$ & $\begin{array}{l}\text { Enlaçand } \\
\text { o } \\
\text { Sexualida } \\
\text { des }\end{array}$ & 2015 & Artigo \\
\hline
\end{tabular}




\begin{tabular}{|c|c|c|c|c|c|c|}
\hline nordestina. & & & & & & \\
\hline Título & Autor@s & Assunto & Área & Fonte & Ano & Tipo \\
\hline $\begin{array}{l}\text { 23-Meus filhos e } \\
\text { os deles: os filhos } \\
\text { da esperança }\end{array}$ & $\begin{array}{l}\text { Maria Simone } \\
\text { Vione } \\
\text { Scwengber }\end{array}$ & $\begin{array}{l}\text { Investiga a } \\
\text { influência da } \\
\text { pobreza nos } \\
\text { sentidos de } \\
\text { maternidade } \\
\text { produzidos por } \\
\text { mães } \\
\text { adolescentes. }\end{array}$ & Educação & $\begin{array}{l}\text { Biblioteca } \\
\text { on line } \\
\text { ANPED }\end{array}$ & 2015 & Artigo \\
\hline $\begin{array}{l}\text { 24- Transição } \\
\text { para a } \\
\text { parentalidade e a } \\
\text { coparentalidade: } \\
\text { casais que os } \\
\text { filhos } \\
\text { ingressaram na } \\
\text { escola ao término } \\
\text { da licença- } \\
\text { maternidade }\end{array}$ & $\begin{array}{l}\text { Liana } \\
\text { Pasinato; } \\
\text { Clarisse } \\
\text { Pereira } \\
\text { Mosmann }\end{array}$ & $\begin{array}{l}\text { Estudo } \\
\text { sóciodemográfico } \\
\text { que investigou a } \\
\text { transição para a } \\
\text { parentalidade e } \\
\text { coparentalidade } \\
\text { em casais cujos } \\
\text { filhos ingressaram } \\
\text { na Educação } \\
\text { Infantil ao } \\
\text { término da licença } \\
\text { maternidade. }\end{array}$ & Psicologia & $\begin{array}{l}\text { Plataform } \\
\text { a Scielo }\end{array}$ & 2016 & Artigo \\
\hline $\begin{array}{l}\text { 25- Mulheres e } \\
\text { filhos menores de } \\
\text { três anos: } \\
\text { condições de vida }\end{array}$ & $\begin{array}{l}\text { Fabiana Silva } \\
\text { Fernandes; } \\
\text { Nelson } \\
\text { Gimenes; } \\
\text { Juliana dos } \\
\text { Reis } \\
\text { Domingues } \\
\end{array}$ & $\begin{array}{l}\text { Discute a } \\
\text { importância social } \\
\text { da Educação } \\
\text { Infantil para as } \\
\text { mulheres que } \\
\text { contam com esse } \\
\text { serviço. }\end{array}$ & Educação & $\begin{array}{l}\text { Plataform } \\
\text { a Scielo }\end{array}$ & 2017 & Artigo \\
\hline $\begin{array}{l}\text { 26- Educação } \\
\text { Física na } \\
\text { Educação } \\
\text { Infantil: } \\
\text { educando } \\
\text { crianças ou } \\
\text { meninos e } \\
\text { meninas? }\end{array}$ & $\begin{array}{l}\text { Marina } \\
\text { Mariano; } \\
\text { Helena } \\
\text { Altmann. }\end{array}$ & $\begin{array}{l}\text { Estudo sobre a } \\
\text { produção das } \\
\text { (des)igualdades } \\
\text { de gênero em } \\
\text { aulas de Educação } \\
\text { Física na } \\
\text { Educação Infantil }\end{array}$ & Educação & $\begin{array}{l}\text { Plataform } \\
\text { a Scielo }\end{array}$ & 2016 & Artigo \\
\hline $\begin{array}{l}\text { 27- Igualdad de } \\
\text { genero en las } \\
\text { instituciones } \\
\text { educativas de la } \\
\text { primera infancia } \\
\text { brasileña }\end{array}$ & Daniela Finco & $\begin{array}{l}\text { Análise sobre as } \\
\text { políticas para a } \\
\text { igualdade de } \\
\text { gênero e } \\
\text { formação docente } \\
\text { e os desafios de se } \\
\text { colocar em prática } \\
\text { o reconhecimento } \\
\text { de outros valores } \\
\text { ligados á } \\
\text { feminilidade e } \\
\text { masculidade. }\end{array}$ & Educação & $\begin{array}{l}\text { Plataform } \\
\text { a Scielo }\end{array}$ & 2015 & Artigo \\
\hline
\end{tabular}




\begin{tabular}{|c|c|c|c|c|c|c|}
\hline Título & Autor@s & Assunto & Área & Fonte & Ano & Tipo \\
\hline $\begin{array}{l}\text { 28- Socialização } \\
\text { do cuidado e } \\
\text { desigualdades } \\
\text { sociais }\end{array}$ & Bila Sorj & $\begin{array}{l}\text { Comentário sobre } \\
\text { o regime do care } \\
\text { no Brasil,que } \\
\text { revela } \\
\text { desigualdades de } \\
\text { gênero e de classe } \\
\text { evidenciados na } \\
\text { questão do } \\
\text { trabalho } \\
\text { doméstico. }\end{array}$ & $\begin{array}{l}\text { Sociologi } \\
\text { a }\end{array}$ & $\begin{array}{l}\text { Plataform } \\
\text { a Scielo }\end{array}$ & 2014 & Artigo \\
\hline $\begin{array}{l}\text { 29-Concepção } \\
\text { dos professores } \\
\text { de educação } \\
\text { infantil sobre o } \\
\text { conceito de } \\
\text { gênero }\end{array}$ & $\begin{array}{l}\text { Erica Farias de } \\
\text { Oliveira }\end{array}$ & $\begin{array}{l}\text { Discute como os } \\
\text { professores de } \\
\text { educação infantil } \\
\text { entendem o } \\
\text { conceito de } \\
\text { gênero e suas } \\
\text { implicações em } \\
\text { sala de aula }\end{array}$ & Educação & $\begin{array}{l}\text { Plataform } \\
\text { a Scielo }\end{array}$ & 2017 & Artigo \\
\hline $\begin{array}{l}30 \text {-Educação } \\
\text { infantil em tempo } \\
\text { integral nos } \\
\text { municípios de } \\
\text { Serra e Vila } \\
\text { Velha: os planos } \\
\text { municipais em } \\
\text { destaque' }\end{array}$ & $\begin{array}{l}\text { Telmy Lopes } \\
\text { De Oliveira }\end{array}$ & $\begin{array}{l}\text { Pesquisa os } \\
\text { desafios à } \\
\text { implementação } \\
\text { das escolas de } \\
\text { tempo integral } \\
\text { considerando as } \\
\text { açõespolíticas das } \\
\text { secretarias e } \\
\text { conselhos de } \\
\text { educação }\end{array}$ & Educação & $\begin{array}{l}\text { Banco de } \\
\text { teses e } \\
\text { dissertaçõ } \\
\text { es Capes }\end{array}$ & 2016 & $\begin{array}{l}\text { Dissert } \\
\text { ação }\end{array}$ \\
\hline $\begin{array}{l}\text { 31-Um olhar } \\
\text { sobre as práticas } \\
\text { pedagógicas que } \\
\text { transgridem } \\
\text { estereótipos de } \\
\text { gênero na } \\
\text { Educação Infantil } \\
\text { na região } \\
\text { metropolitana de } \\
\text { Belo Horizonte } \\
\end{array}$ & $\begin{array}{l}\text { Lorena } \\
\text { Marinho Silva } \\
\text { Aguiar }\end{array}$ & $\begin{array}{l}\text { Se debruça sobre } \\
\text { práticas docentes } \\
\text { transgressoras das } \\
\text { relações de } \\
\text { gênero } \\
\text { conservadoras }\end{array}$ & Educação & $\begin{array}{l}\text { Banco de } \\
\text { teses e } \\
\text { dissertaçõ } \\
\text { es Capes }\end{array}$ & 2016 & $\begin{array}{l}\text { Dissert } \\
\text { ação }\end{array}$ \\
\hline $\begin{array}{l}\text { 32-A infância e } \\
\text { as questões de } \\
\text { gênero em } \\
\text { instituições de } \\
\text { educação infantil }\end{array}$ & $\begin{array}{l}\text { Daniane } \\
\text { Fatima } \\
\text { Quadrado } \\
\text { Caminero }\end{array}$ & $\begin{array}{l}\text { Investiga a } \\
\text { relação de } \\
\text { padrões nas } \\
\text { interações adulto- } \\
\text { criança relativos à } \\
\text { reprodução de } \\
\text { estereótipos de } \\
\text { gênero e os } \\
\text { movimentos de } \\
\text { transgressão por } \\
\text { parte da criança }\end{array}$ & Educação & $\begin{array}{l}\text { Banco de } \\
\text { teses e } \\
\text { dissertaçõ } \\
\text { es Capes }\end{array}$ & 2016 & $\begin{array}{l}\text { Disser } \\
- \\
\text { tação }\end{array}$ \\
\hline
\end{tabular}




\begin{tabular}{|c|c|c|c|c|c|c|}
\hline Título & Autor@s & Assunto & Área & Fonte & Ano & Tipo \\
\hline $\begin{array}{l}\text { 33- Relações de } \\
\text { gênero e docência } \\
\text { na educação } \\
\text { infantil: } \\
\text { interfaces entre } \\
\text { políticas públicas } \\
\text { e abordagens } \\
\text { pedagógicas }\end{array}$ & $\begin{array}{l}\text { Maria Rita } \\
\text { Neves Ramos }\end{array}$ & $\begin{array}{l}\text { Mapeamento dos } \\
\text { desafios de uma } \\
\text { Educação Infantil } \\
\text { não sexista } \\
\text { apoiada em } \\
\text { documentos, } \\
\text { análise de } \\
\text { materiais } \\
\text { formadores e em } \\
\text { entrevistas. }\end{array}$ & Educação & $\begin{array}{l}\text { Banco de } \\
\text { teses e } \\
\text { dissertaçõ } \\
\text { es Capes }\end{array}$ & 2016 & $\begin{array}{l}\text { Dissert } \\
\text { ação }\end{array}$ \\
\hline $\begin{array}{l}\text { 34- Socialização } \\
\text { de gênero na } \\
\text { Educação } \\
\text { Infantil: uma } \\
\text { análise a partir da } \\
\text { perspectiva das } \\
\text { crianças }\end{array}$ & $\begin{array}{l}\text { Sandro } \\
\text { Vinicius Sales } \\
\text { Dos Santos }\end{array}$ & $\begin{array}{l}\text { Analise dos } \\
\text { sentidos que } \\
\text { crianças de cinco } \\
\text { anos produzem } \\
\text { sobre as relações } \\
\text { de gênero }\end{array}$ & Educação & $\begin{array}{l}\text { Banco de } \\
\text { teses e } \\
\text { dissertaçõ } \\
\text { es Capes }\end{array}$ & 2016 & Tese \\
\hline $\begin{array}{l}\text { 35-Educação } \\
\text { infantil em tempo } \\
\text { integral: em } \\
\text { busca de uma } \\
\text { philia social }\end{array}$ & $\begin{array}{l}\text { Vania } \\
\text { Carvalho de } \\
\text { Araújo }\end{array}$ & $\begin{array}{l}\text { Estuda as } \\
\text { concepções e } \\
\text { simbologias da } \\
\text { educação em } \\
\text { tempo integral. }\end{array}$ & Educação & $\begin{array}{l}\text { Plataform } \\
\text { a Scielo }\end{array}$ & 2017 & Artigo \\
\hline $\begin{array}{l}\text { 36-Educação } \\
\text { Infantil: Tempo } \\
\text { Integral Ou } \\
\text { Educação } \\
\text { Integral? }\end{array}$ & $\begin{array}{l}\text { Maria Carmen } \\
\text { Silveira } \\
\text { Barbosa, } \\
\text { Sandra Regina } \\
\text { Simonis } \\
\text { Richter;Ana } \\
\text { Cristina Coll } \\
\text { Delgado }\end{array}$ & $\begin{array}{l}\text { Analisa se a } \\
\text { proposta de } \\
\text { educação integral } \\
\text { pode se aplicar à } \\
\text { turnos } \\
\text { prolongados, discu } \\
\text { tindo as } \\
\text { intencionalidades } \\
\text { do tempo integral. }\end{array}$ & Educação & $\begin{array}{l}\text { Plataform } \\
\text { a Scielo }\end{array}$ & 2015 & Artigo \\
\hline $\begin{array}{l}37-\text { Relações } \\
\text { sociais de gênero } \\
\text { na perspectiva de } \\
\text { crianças } \\
\text { pequenas na } \\
\text { creche }\end{array}$ & $\begin{array}{l}\text { Márcia Buss- } \\
\text { Simão }\end{array}$ & $\begin{array}{l}\text { Discute como o } \\
\text { gênero se faz } \\
\text { responsável pela } \\
\text { constituição } \\
\text { corporal de } \\
\text { crianças de uma } \\
\text { escola de tempo } \\
\text { integral }\end{array}$ & Educação & $\begin{array}{l}\text { Plataform } \\
\text { a Scielo }\end{array}$ & 2013 & Artigo \\
\hline $\begin{array}{l}\text { 38-Cuidar: } \\
\text { relações sociais, } \\
\text { práticas e } \\
\text { sentidos no } \\
\text { contexto da } \\
\text { Educação Infantil }\end{array}$ & $\begin{array}{l}\text { Erica Dumont } \\
\text { Pena }\end{array}$ & $\begin{array}{l}\text { Análise do } \\
\text { cuidado como } \\
\text { relação social em } \\
\text { berçário de uma } \\
\text { escola de } \\
\text { Educação Infantil. }\end{array}$ & Educação & $\begin{array}{l}\text { Banco de } \\
\text { teses e } \\
\text { dissertaçõ } \\
\text { es Capes }\end{array}$ & 2015 & Tese \\
\hline
\end{tabular}




\section{ANEXO 1:}

CARTAZ DE CHAMADA PÚBLICA PARA CADASTRAMENTO EM CRECHES EM JUIZ DE FORA (MG)

Fonte: https://colunaacontecendo.blogspot.com/2017/10/cadastramento-nas-crechesmunicipais-de.html

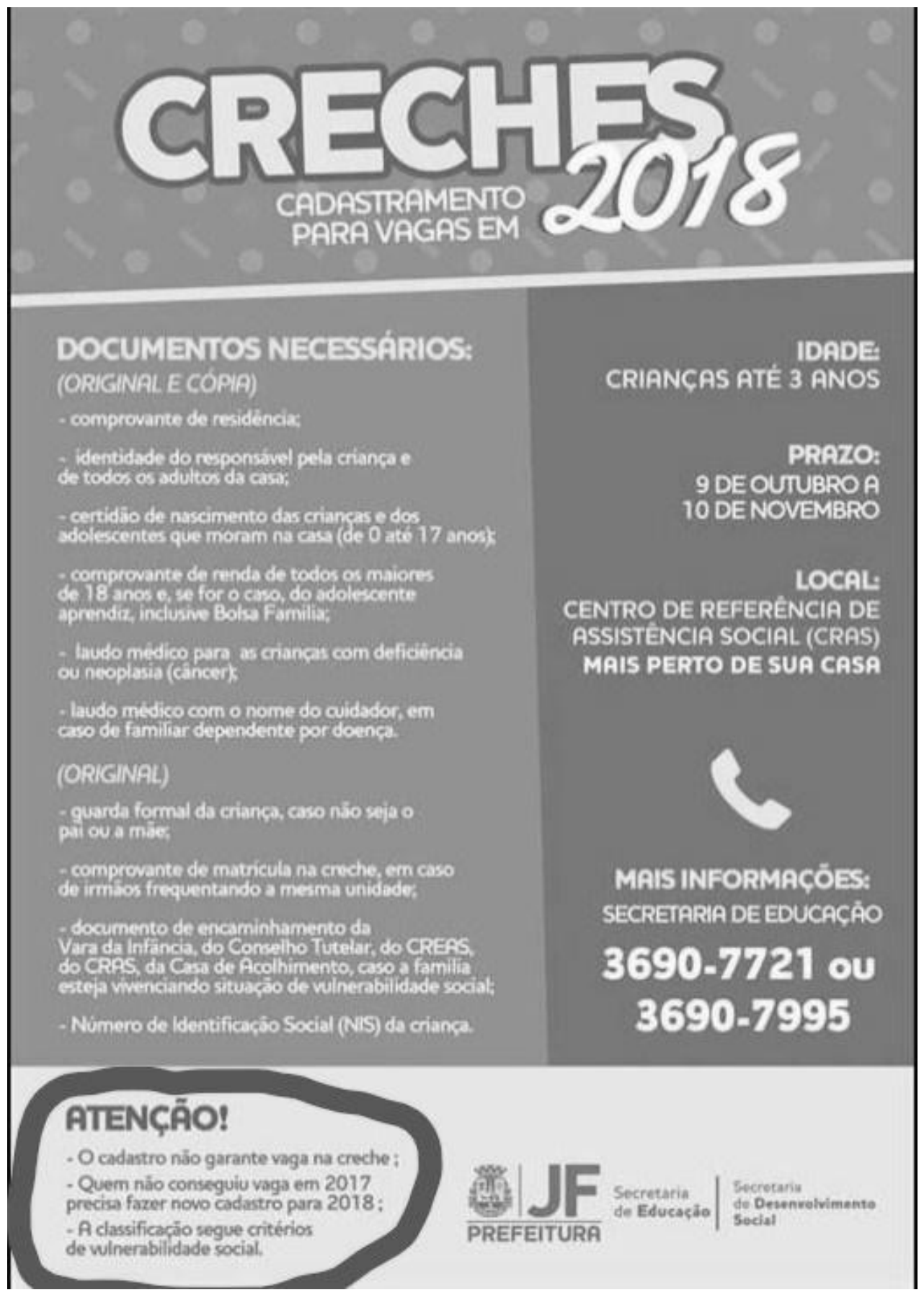

